\title{
DESCRIPCIÓN DE UN EJEMPLAR ESCULTÓRICO DE SAN AGUSTÍN-HUILA
}

\section{MARÍA CRISTINA TORO ZAMBRANO}

\author{
INVESTIGACIÓN: \\ Para optar al título de Maestría en Filosofía Latinoamericana
}

DIRIGIDO POR:

Ángel María Sopó

UNIVERSIDAD SANTO TOMÁS DE AQUINO BOGOTÁ

2014 


\section{AGRADECIMIENTOS,}

Gracias al profesor Ángel María Sopó por su paciencia y tiempo dedicado a esta investigación, por ser guía y formador en el camino filosófico.

Gracias al Seminario Privado de Fenomenología y a todos los integrantes por hacer del ámbito filosófico un espacio libre, riguroso y agradable.

A Brigitte por sus acertadas y ambles correcciones en cuanto al estilo del texto. A Luis Carlos por siempre estar ahí, en ese instante preciso, cuando he necesitado su ayuda para realizar este trabajo. A mis padres por siempre creer en mí. 


\section{CONTENIDO}

PÁG

Presentación.

\section{CAPITULO I}

1. El método fenomenológico para un hacer reflexión filosófica latinoamericana. 1

1.1. La difícil tarea de decir: ¿Qué es la fenomenología? 3

1.2. ¿Qué problemas son realmente fenomenológicos? 12

1.3. Todo es cuestión del método fenomenológico 19

1.4. ¿Cómo es posible una reflexión latinoamericana desde la fenomenología?40

\section{CAPITULO II}

2. El ver fenomenológico de la obra de arte.

2.1 La vivencia estética auténtica y originaria

2.3 El derrocamiento del sentido originario en la escultura de San agustín.

\section{CAPITULO III}

3. La escultura agustiniana como lugar otro

3.1 La utopía del sentido germinador de la escultura agustiniana

3.2 La heterotopía funeraria de la escultura agustiniana.

\section{BIBLIOGRAFÍA}




\section{PRESENTACIÓN}

El presente trabajo es el desarrollo de una investigación que he venido realizando desde 2011 acerca de la escultura de San Agustín-Huila, la cual, se ha enriquecido con las continuas visitas a este sitio arqueológico del país, las lecturas de los documentos históricos, arqueológicos, etnográficos, sociológicos que se han escrito sobre este particular, así como los archivos fotográficos y artísticos que de él se han registrado; permitiendo llevar a cabo una experiencia radicalmente personal y cercana con las obras líticas y su entorno. Como parte del trabajo filosófico, me he permitido realizar descripciones desde la vivencia filosófica de un ejemplar escultórico, que visto desde una perspectiva fenomenológica, abren una posibilidad en el camino de la filosofía latinoamericana, donde se toman para la reflexión fenómenos inmediatos de nuestro mundo.

Por ello, es necesario exponer las pautas y reglas de método que postula Edmund Husserl, que he apropiado haciendo una una lectura en primera persona, es decir, partiendo de mis experiencias, para vislumbrar la relevancia del ejercicio de la descripción fenomenológica, entender los problemas fenomenológicos. Vivir el paso de la actitud natural a la escéptica y a la reflexiva, la dificultad de tematizar para realizar una reducción fenomenológica, una ideación, la clarificación de una esencia, y finalmente la contemplación que permite ir a la exposición y declaración de una posible vivencia trascendental de mi fenómeno.

Por tal motivo todo el trabajo está escrito, en primera persona y desde la vivencia personal, según la exigencia que se da en el método fenomenológico, porque solo aquel que lo realiza desde sí mismo puede comprenderlo y aplicarlo a cabalidad, como tarea radicalmente subjetiva, dice Husserl: "es cosa manifiesta que yo sólo puedo aclarar la esencia del conocimiento si la veo por mí mismo y si me da a la vista ella misma tal como es" (1982,p.57) nadie puede hacer que veamos la esencia de nuestro objeto de conocimiento, solamente el investigador que la ve por sí mismo.

Esta investigación sobre la escultórica de San Agustín-Huila es valiosa y novedosa, no solo en lo que refiere a su estilística expositiva y aplicación del método, sino también porque no 
se ha escrito un trabajo sobre dichas obras, desde la perspectiva filosófica. Se encuentran datos e informes académicos de historia, arqueología, etnografía, sociología, geografía, más no del campo de la filosofía en general. Con lo cual este trabajo abre el camino para hacer otras lecturas desde la filosofía de la cultura, la filosofía de la religión, una filosofía del lenguaje simbólico, o un trabajo tomando como base conceptual a Martín Heidegger, Jean Luc-Marión, Merleau-Ponty u otros métodos filosóficos.

El desarrollo de la investigación sobre lo ejemplar de mi entorno, me permitieron indagar en una línea filosófica con el fin de explorar el mundo de la vida con ojos fenomenológicos. De allí el título del primer apartado: "El método fenomenológico para un hacer reflexión filosófica latinoamericana", en el cual se explicita la relevancia de esta mirada filosófica para tratar una obra escultórica agustiniana y a partir de ella el resto de escultura y su entorno, ya que "la fenomenología ha de ponerse ante la vida, a título de ejemplares..." (1949, p. 148) En este apartado, los ejemplos de vida llevan a explicar cada uno de los elementos del método fenomenológico, desde una forma de apropiación personal de lo que significa; la vivencia, la actitud natural y reflexiva, sin teorías, esencia, la descripción, la tematización, la aclaración, la epojé, la aclaración, etc. términos propios de la fenomenología husserliana. Y con lo cual se consigue la comprensión del modo de proceder de los siguientes capítulos.

De allí que el ejercicio que se indica en el segundo capítulo: "El ver fenomenológico de la obra escultórica agustiniana", es la realización de la descripción que permite ver los aspectos propios del arte en general y del arte escultórico en particular, poniendo entre paréntesis las teorías que se han establecido en el ejemplar "dios sol", sus recuerdos, su archivo, vistos desde la vivencia radicalmente personal y que conducen a una reflexión sobre el desplazamiento, el derrocamiento del sentido originario, el saqueo, la imposición de nombres y sentidos de la que ha sido objeto la pieza artística.

En dicha descripción, la obra misma se muestra entre lo visible y lo invisible, se aclara la vivencia auténtica y originaria que puede tener el espectador-reflexivo al estar frente a ella, respondiendo a la pregunta, ¿Cuál es la esencia de la escultura agustiniana? cuestión que conduce a tratar las noticias de cronistas, arqueólogos, etnólogos y expedicionarios de San Agustín, para así, poner en cuestión, tematizar y hacer epojé de su acierto o desacierto 
en la construcción o destrucción de un sentido originario. De allí, que al encontrar una esencia no-originaria, ésta se manifiesta en otras obras como el "doble-yo", "la flaustista", “el obispo", en tumbas y sarcófagos, que finalmente, hacen patente lo no-originario en la correlación con el mundo cultural del pueblo escultor.

Después de la aclaración y visibilización de la esencia, la obra exige postular un horizonte de sentido distinto a los que han marcado su historiografía. No satisfecha con lo encontrado, propongo a modo de posibilidad, una perspectiva para entender y ver la escultórica de San Agustín y su mundo-entorno como un lugar otro. Por tal razón el tercer y último capítulo se titula: "la escultura agustiniana como lugar otro".

Como lugar otro, la escultura, cobra vida y sentido universal, sea a través de una u-topía de la germinación de la vida o desde una hetero-topía funeraria. Ambos lugares modifican la relación que tenemos con la obra. En la primera, la idea de lo sagrado tiene un desarrollo que se mezcla con el esoterismo y con prácticas meditativas, en la segunda; la idea de lo trascendente se relaciona con el culto a la muerte, y la existencia de un cementerio ancestral. Pero como utopía o heterotopía, la escultura es en la actualidad objeto del ecoturismo o "esoturismo" cultural.

Toda la indagación que se hace en este trabajo investigativo es en primera persona, y está escrito como tal desde el inicio hasta el final, ya que no tendría validez alguna si no realizara la máxima filosófica donde todo conocimiento del mundo es al mismo tiempo autoconocimiento. Por lo cual, tratar una pieza escultórica y describirla para ver su sentido originario y esencial -de ella y su mundo circundante- es también vislumbrar una descripción de sí mismo, como espejo de esa comunidad primitiva que refiere un conocimiento de sí mismo y como parte de ese lugar otro en construcción.

Es así, como todo el escrito está trazado con descripciones de ejemplares particulares, personales que vienen del recuerdo y la experiencia vivida, para entender el sentido del método fenomenológico y la profundidad que tiene el tomar, lo ejemplar de la obra escultórica de san Agustín, para entender su todo, a partir del lugar no-originario de la obra, y los lugares-otros que se pueden comprender desde allí. Ello solo se comprende en la elaboración de un trabajo arduo y detallado, pero que sigue en construcción, nunca está acabado, ya que como diría Husserl: "lo que las ideas refieren es - como sigue siendo mi 
convicción- un fragmento inicial del trabajo efectivo que entre tanto me he esforzado constantemente por continuar" (Epílogo Ideas, p. 140) por ello esta investigación se postula como base de un trabajo doctoral. 


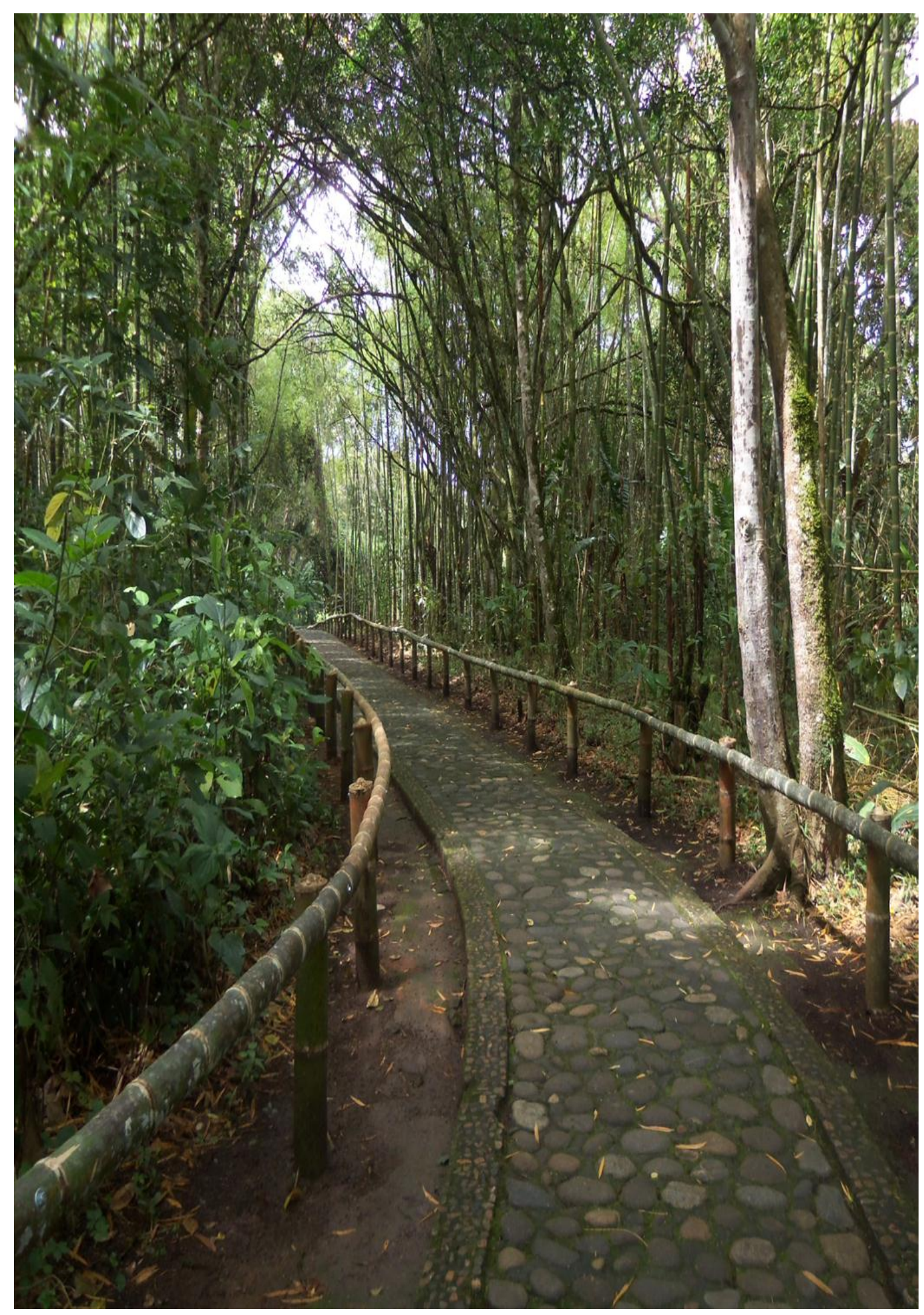




\section{CAPÍTULO I}

\section{EL MÉTODO FENOMENOLÓGICO PARA UN HACER REFLEXIÓN FILOSÓFICO LATINOAMERICANA}

No soy una fenomenóloga, tampoco una autoridad en el tema, soy una simple lectora principiante de asuntos fenomenológicos. Muchas veces, había escuchado hablar de fenomenología, pero mis oídos sólo prestaban atención a intereses filosóficos novedosos, que gritaban ir en contra de la historia tradicional de las ideas (Foucault, 2005, p.54) bajo el rótulo de un neo estructuralismo de origen francés. La fenomenología era entonces algo que me sonaba extraño, sin sentido y entraba -como muchos conceptos- en los que debía apartar, para hacer una real filosofía del presente.

En aquel tiempo, la fenomenología era una palabra más de algún sistema filosófico complejo y cientificista que no me seducía leer. La asociaba a nombres como Hegel, Husserl y Heidegger, que oía de boca de mis profesores -a quienes veía- como especialistas de esa gruesa filosofía, a la cual no quería pertenecer. Pero ahora, veo que la lista de autores se ha extendido y mi desconocimiento frente a este asunto es cada vez más infinito.

Al buscar información sobre ese concepto, me encuentro con una conferencia de Lester Embree, fenomenólogo norteamericano, que menciona para el año 2009, variantes de esa gruesa fenomenología, que ha sido abordada desde diferentes posiciones y que son para este autor, destacables florecimientos. De allí, cita por ejemplo a la fenomenología realista y la fenomenología política, que comienza con Adolf Reinach; la ética fenomenológica con Scheler; la estética fenomenológica con Moritz Geiger y especialmente, con Roman Ingarden; la fenomenología de la religión, con muchos de los estudiantes tempranos y con el francés Jean-Luc Marion; la fenomenología de las ciencias culturales de Alfred Schutz, 
Gustav Špet y también con "Edith Stein; la última de las cuales inició así mismo la fenomenología del género".

Menciona además a la fenomenología constitutiva y metafísica de origen alemán con Martin Heidegger, Eugen Fink y Ludwig Landgrebe. Una fenomenología existencial francesa con Simone de Beauvoir, Mikel Dufrenne, Maurice Merleau-Ponty y Jean-Paul Sartre. Una fenomenología hermenéutica, "liderada por Gadamer y Paul Ricoeur" (Embree, 2009, p.162).

Al final habla de unas novedades, como: la fenomenología de la tecnología, que según él inició con el temprano Scheler, pero que se desarrolla en Gabriel Marcel; y "la fenomenología del cine, que comenzó en el estadio de la fenomenología existencial, y parece estarle yendo muy bien en estos días." Hay otras a las que se hacen alusión, como por ejemplo a: La psiquiatría fenomenológica, la enfermería fenomenológica, la comunicología fenomenológica, la sociología fenomenológica y la pedagogía fenomenológica.

En pocas palabras, si de fenomenologías se trata, hay muchas para diferentes gustos. Así que según Embree, "La fenomenología filosófica no es en modo alguno la única disciplina dentro de nuestra tradición. Claramente es la más extensa y ha tenido gran influencia sobre disciplinas fuera de la filosofía.” (2009, p.163) y cada una de ellas tiene sus variantes, interpretaciones y apropiaciones distintas de lo que es fenomenología.

Pero como principiante, entré en la tarea de oír y escuchar al padre, quien tiene la autoridad para dejarme ver en el meollo de la fenomenología propiamente dicha. Su nombre, Edmund Husserl, filósofo alemán que postula una nueva ciencia: la fenomenología. Él entiende el acto filosófico como un hacer fenomenológico, donde el mundo es un campo fenomenológico de vivencias y donde los objetos de conocimiento son fenómenos que deben ser tratados desde un método fenomenológico.

En la fenomenología todo es una novedad, todo concepto es excepcional, hay que entenderlo en un sentido distinto, en su propia clave y con ritmo particular, es -como dice el propio Husserl- entrar a un reino a un "nuevo campo de experiencia" "un reino que por razones esenciales ha permanecido hasta aquí inasequible" $(1949$, p.374) que requiere no 
desprender de las teorías anteriores, porque siendo "presa de los hábitos mentales de la tradición filosófica, se pasa de largo sin ver lo que hay de radicalmente nuevo en el método y en el campo de trabajo de esta fenomenología” (Ibíd., p.372).

No soy una mujer de moda, ni conozco mucho de "lo nuevo", pero la novedad radical que Husserl me dice, es que para hacer filosofía, debo entrar en el mundo de la fenomenología y para ello, debo ver con nuevos ojos, cambiar de actitud, vivir de otro modo y tener mi propio estilo. Dejándome sólo con el instrumento del método, aquella llave abrirá las cerraduras más difíciles de cuyas puertas se esconde la comprensión de la fenomenología. Y así lograré hacer realmente filosofía.

La tarea no es fácil, más cuando se trata de sí mismo. Describir y abstraer desde mi propio yo. Donde mis sentidos, el cuerpo, el aliento están estrechamente relacionados con el ejercicio del pensar. Cosa novedosa para mí, ya que en la academia me sentía a veces extraña, como si el quehacer filosófico fuera cosa de citar autores, leer libros de mil páginas incomprensibles, escribir con cierta coherencia y objetividad, rompiendo con todo el sentido del gusto por la escritura, hablar con destreza y repetir palabras extravagantes para oídos mundanos. Fuera del salón de clases, la vida, el cuerpo, la sed, las buenas lecturas, la palabra inventiva, las preguntas, las contradicciones, la risa, el sentido, yo. No hay nada más novedoso y presente que la vivencia cotidiana que puedo tener desde mi misma y esa es la tarea real que me he propuesto realizar en este trabajo.

\subsection{La difícil tarea de decir ¿Qué es la fenomenología?}

Es difícil tratar de definir aquí la idea que Husserl tenía de "fenomenología", incluso es anti-fenomenológico llegar a estipularla como algo fijo y determinante, no sólo porque se presenta de forma distinta en sus textos, dándole unas significaciones particulares, sino también, por la dificultad que presenta exponer esta idea, desde la esquina de mi incomprensión. Así pues, en esta tarea hablaré como una lectora principiante de la obra de Husserl, tratando de aclararme esta idea y de responder a la pregunta inicial.

Para comenzar, tomo de la sección tercera de Ideas I, la cita donde Husserl dice que la fenomenología se puede entender como: "una ciencia esencial puramente descriptiva" (1949, p.148) Se tienen cuatro elementos: 1) La fenomenología es una ciencia. 2) Es una 
ciencia esencial. 3) Es una ciencia esencial pura. 4) Es una ciencia esencial pura y "descriptiva".

Ello indica de antemano, que la fenomenología es una ciencia, no es un mero pensamiento, ni tampoco una técnica de estudio, no debe confundírsele con otras tantas formas de abordar un objeto cualquiera, para decir algo nuevo o diferente. Se trata de una ciencia que como las demás, tiene una pretensión de universalidad, su programa epistemológico riguroso, unos objetos de estudio, crea un método para su abordaje, posee un lenguaje particular y construye sus horizontes. $\mathrm{Y}$ sin embargo, es una ciencia de carácter apodíctico $^{1}$, (Husserl, 1985, p. 367) cuya necesariedad no la hace depender de otras ciencias, ni filosofías anteriores. Sus problemas surgen de ella misma de un modo incondicionado y con una mirada propia.

La fenomenología no es una ciencia cualquiera que tiene como adjetivo la rigurosidad. No es matemática, no es una ciencia de la naturaleza, ni tampoco física. A pesar de que Husserl dedicó en Berlín su estudio a este conocimiento y aunque amaba -según Malvine "Los áridos cálculos con las tablas... [y] su amor gravitaba aun exclusivamente en torno a las matemáticas ... educado en las ciencias naturales exactas por los espíritus más grandes de su tiempo" (2010, p.2) - esta nueva ciencia, trata de las esencias y se distingue de otras que también buscan universalidad, rigor e ideas fundantes.

Sigue la frase rondando en mi cabeza... La fenomenología es una ciencia esencial, pero ¿de qué esencias habla Husserl? No se trata aquí, de las esencias que cree haber trabajado las matemáticas, cuya base son los números, la postulación de fórmulas y axiomas, ni se trata de aquellas en las que las ciencias naturales se basan para los procesos reales de la physis.

Replico ¿una ciencia esencial? La fenomenología es una ciencia que se preocupa por las esencias, pero ello no me aclara el asunto. En el $\$ 66$ de Ideas I Husserl, llamará a la fenomenología: “doctrina de esencias dentro de una intuición pura” (1949, p.150) nada más abstracto e incomprensible en la filosofía que "lo puro".

\footnotetext{
1 "La filosofía, auténtica ciencia, tiene como fin dicha constitución, aunque sea aproximándose a ella gradualmente, a través de su recurso al Eidos, a priori puro, que es accesible a todos en la intelección apodíctica."
} 
El trabajo de la fenomenología es tomar las esencias que se le aparecen a la conciencia en forma de ideas, ¿Cómo se le aparecen? ¿A qué conciencia? ¿Cuál es la forma de esas ideas? Pero ese no es el camino para empezar a entender la fenomenología. Hay que ir a las cosas mismas para ver las esencias. Husserl no responde por ahora a mis preguntas, sólo me da una pista para entenderla: "sin teorías" (1977, p.18)

Hay un principio metodológico para hacer fenomenología: "nada de ciencias mediante renacimientos sino ciencia a partir de las cosas mismas" (Ibíd.) Así aparecerán las esencias de las cosas, pero estas no llegan a mis manos, como un conejo que sale del sombrero vacío del mago, se dan en la intuición, ahí en ese lugar oscuro late su corazón, sólo se siente el latido, puramente el latido, aún no se ve, no tiene forma, se mueve, pero todavía no es conejo, no está la idea de conejo, porque no he tenido la experiencia con el mago.

De allí, que también puede llamársele a la fenomenología una ciencia eidética, porque trabajará, no con la esencia, allá afuera de la intuición como sombra viviente y autómata, sino con las ideas que aparecen en el intelecto sobre esa cosa externa. La esencia que Husserl me indica es el eidos que la intuición captura, para escudriñar las cosas del mundo, pero estas ideas no se dan con un chasquido mental, requieren de lo concreto para ser visibles, porque son también de origen material.

Ello suena abstracto, sea por lo de ciencia, sea por lo de esencias o por lo de intuición eidética. Hablamos de una ciencia que no ha renunciado a la importancia de las ideas como fundamento del conocimiento. Cosa que para nuestros oídos últimamente acostumbrados a discursos "post", lo esencial y lo puro, es un tema obscuro y del pasado remoto. Sin embargo, esta ciencia también reconoce lo concreto como parte de sus problemas. No hay una distinción real entre la idea y lo concreto de la esencia. Ambas son facetas del mismo fenómeno. La esencia está en el fenómeno. Y esa esencia se da en lo concreto y se da en la idea, ¿Pero cómo se da esta relación? ¿Quién la establece? ¿A través de qué es posible esta correlación?

Vuelvo al comienzo, la fenomenología es una ciencia esencial puramente descriptiva. Hay que diferenciar esta ciencia de otras que también se definen puras, esenciales y eidéticas, pero que nada tienen que ver con el modo de proceder de la fenomenología. Las ciencias exactas como la matemática, buscan definiciones a través de axiomas, donde se explican 
los objetos de su conocimiento; "estas son ciencias deductivas... prevalece sin comparación el conocimiento deductivo inmediato... [donde] una infinidad de deducciones descansan ahí sobre unos pocos axiomas” (Husserl, 1949, p.376)

Muy distinto de la manera fenomenológica, la cual describe las esencias. No las define, no instaura principios desde los cuales se deducen lógicamente su significado, sino que entra en su multiplicidad para describirlas. Al describir, no se busca dar juicios categóricos sobre el fenómeno de nuestro conocimiento, sea éste el mundo o nuestro propio yo. Describir implica un acto de desmenuzar, cómo el ponqué se vuelve migas de pan o cómo la tradicional arepa un costal de maíz molido, para llegar al grano de su constitución.

Con este proceder, se elimina la posibilidad de instaurar principios definitivos de manera inmediata. Implica, antes de toda reflexión, un ver el fenómeno en su manifestación, en el modo en que se me aparece. Sin pre-juicios, sin supuestos, sin teorías. Este describir no es simple, llano e inmóvil, sino que es constante, profundo y complejo en el tratamiento de las esencias, las cuales sólo se aprehenden con la descripción, "un trabajo y no una construcción, una descripción sacada de una real intuición universal de esencias" (1949, p.375).

¿Quién ve las esencias? ... El que aprende a ver, ve. El que sabe ver, ve. Quizá el investigador o el expedicionario, están habilitados para realizar el análisis descriptivo de esos fenómenos, en un marco de referencia donde la intuición pura del intelecto, sea capaz de capturar su esencia claramente. Para Husserl es el principiante el que puede ver las cosas en su esencia, porque es el que desarrolla esta ciencia verdaderamente desde sus comienzos y de manera universal, el principiante se ocupa de los principios, camina hacia el comienzo, como parte de una investigación originaria. ${ }^{2}$ Y si aún no puedo ver como principiante, puedo hacerlo como co-principiante, que es aquel "oyente que activamente participa en el pensar" (1998, p. 16), pensar el comienzo, el origen, las esencias de las cosas de un mundo circundante.

\footnotetext{
${ }^{2}$ La cita donde Husserl hace referencia al respecto se encuentra en "filosofía primera": "... principiante (iniciador) de la filosofía en su verdadero sentido es aquel que desarrolla la filosofía primera verdaderamente desde sus comienzos ... mientras esta investigación originaria no se haya logrado, no habrá un principiante de la filosofía en este sentido...”(1998,p.16)
} 
En todo caso, la relación esencia pura y ciencia eidética, aún no es clara, para muchos causará risa, ya que hablar de ello en filosofía actual parece ser un tema de una metafísica "superada" o una ontología espiritual ineficiente para nuestro ser contemporáneo, quizá pueda aparecer como asunto de otras disciplinas, como la psicología y la lógica que persiguen la rigurosidad y cientificidad, dejándole a la filosofía los sueños, las utopías y la infinita especulación; o tal vez, le ha dejado la materialidad, el realismo, la política, la estética y la ética, como temas de su reflexión, olvidando el problema del comienzo y lo esencial.

Pero el tema no está superado y Husserl vuelve a él para retomarlo con el fin de postular su nueva idea de filosofía. Y ahora, yo vuelvo a su reflexión, para realizar un hacer fenomenológico del mundo que se me aparece en lo inmediato, el mundo de la vida donde se despliega mi lengua y mis vivencias como una actualidad latente.

Esas vivencias se convierten en una tarea de auto-reflexión constante e infinita, que permite el conocimiento amplio de mí misma y de mi mundo de una manera radical. Vistas desde su raíz, allí habitan las esencias, que son, el sentido originario que le doy a mis experiencias. Daniel Herrera, lo podría decir mejor al interpretar una cita de Crisis: "Husserl afirma que el mundo de la vida es el mundo de la experiencia concreta precientífica donde el hombre se instala, actúa, construye proyectos y se realiza como científico, político, como creyente..." (2002, p.12).

La fenomenología es ciencia y es ciencia estricta, en la medida en que camina hacia las cosas propiamente filosóficas hasta llegar a su origen. Busca "formular los problemas filosóficos, diferenciarlos y delimitarlos mediante el trabajo teórico, en tal medida que llega a problemas de trabajo que ofrezcan una seria perspectiva de solución real." (Husserl, 1977, p.17).

Se trata de una ciencia en búsqueda del sentido de nuestra vida individual y concreta, llena de alti-bajos, sensaciones, acciones, imaginación, elementos propios de la cotidianidad del hombre, que son tomados como reflexión universal, para que a través de la intuición, sea posible captar el eidos que cada uno de ellos contiene, despojados capa por capa de toda su realidad fáctica, tomados en su puro sentido, para luego ser expuestos y aclarados 
intelectivamente. Se trata pues, de cumplir el principio fenomenológico de ir a las cosas mismas.

En definitiva se busca entender que la fenomenología como ciencia esencial, pura y eidética, es propiamente filosofía. Es una ciencia auténtica, una Philosophia perennis, una Filosofía Primera. ${ }^{3}$ Y si la fenomenología es una ciencia estricta, la filosofía es, ante todo, estricta y radical, una filosofía que es teoría universal de la vida.

Husserl pone a la fenomenología en un estatus de filosofía, no dentro de las filosofías secundarias, sino como aquella que por sus problemas más originarios, es anterior a todas las demás imaginadas. Una ciencia que como tal, tiene fundamentos y un método propio para sus interrogantes. "...Ha sido mi empeño dar a la fenomenología la forma de desarrollo exigida por la idea de la filosofía primera, o sea, la forma de una filosofía de los comienzos que se conforma a sí misma en la más radical autoconciencia filosófica y en la más absoluta necesidad metódica." (1998, p.18).

Pero no es la filosofía como ciencia natural, por el contrario es más originaria a todas ellas, porque trata de retroceder a la primitiva idea de la filosofía (1949, p.372) la idea del comienzo, del principio. Es un volver a las preguntas fundamentales de la filosofía. Por esto Husserl ve que "la filosofía es para mí, de acuerdo con la idea de la misma, la ciencia que parte de fundamentos últimos" (Ibíd.).

No obstante, la fenomenología es el proyecto de una filosofía entendida desde la idea de ser un comenzar de nuеvo cuyos problemas originarios y universales, hacen parte de un conocimiento del sí mismo que lo implica y reflexiona. No es repetir a Platón, ni a los antiguos, ni a ningún otro. Es iniciar por cuestiones filosóficas universales, pero teniendo como punto de partida una vivencia actual y personal del individuo que se piensa y repiensa el mundo, en un nuevo camino de investigación filosófica que "requiere un progreso metódico inmenso". (Husserl, 2009, p.28).

Una filosofía que es ciencia pero cuya rigurosidad, solo se alcanza con la fenomenología, en el sentido en que toma sus problemas de manera esencial, eidética y originariamente. Ya

\footnotetext{
${ }^{3}$ Términos mencionados en: Filosofía primera. Lección 1. Pág. 15, 16 y 17. Y también en Ideas I pág 146. “ la fenomenología tiene por esencia que aspirar a ser la filosofía primera ..."
} 
que el que realmente hace una filosofía seria realiza una reflexión profunda donde "un inicio sólo puede tener lugar en el iniciador que reflexiona sobre sí mismo.” (1949, p.382).

Vamos por partes. La fenomenología es una ciencia, pero una ciencia subjetiva, que parte del hombre que reflexiona sobre sí mismo, pero cuya reflexión asciende a lo universal. Es una filosofía subjetiva-trascendental, trascendental en el sentido de tomar los problemas y tomarse a sí mismo, no sólo como un particular, sino también, como un universal dentro de un todo que es la humanidad, se trata de un yo que está en relación consigo mismo y con los otros en un mundo común, de manera intersubjetiva.

Es en este análisis, donde la fenomenología cobra un sentido universal. Ya no se trata de ponernos como sujetos ante el mundo empírico, donde hay una afirmación inmanentista del yo concreto -yo dentro del mundo dándole un sentido para mí a lo que me rodea- sino que se presenta de manera trascendental en el yo, donde reflexiono, no sólo como Cristina y mis posibles mundos particulares, con mis convicciones, sino como perteneciente a la humanidad con mis realidades. Es acá cuando mi conciencia, ya no es meramente conciencia de mis posibilidades sino las posibilidades que universalmente puedo concienciar dentro del horizonte de lo humano.

Trascender, en este contexto husserliano, es afirmarse en cuerpo y en conciencia, pero entroncados en una conciencia propia de un tiempo y en un espacio en el que nuestra vida transita, como variante de un proceso común a un todo. Todos como humanos tenemos un sentido de ese mismo mundo que nos rodea. Por tal razón, esta ciencia también tiene un proyecto de humanidad, que va desde la experiencia individual hasta la comunitaria, como una reflexión teleológica del hombre.

Voy a la biblioteca y me hacen una invitación: "invitación a la fenomenología," título del libro que me seduce en su capítulo III con el nombre de La filosofía como autorreflexión de la humanidad de Edmund Husserl. Pocas veces digo no a las invitaciones, y ésta se ve atractiva al postular a la fenomenología como una autorreflexión:

La tarea consiste en comprenderse racionalmente, comprendido que ser racional es querer ser racional; lo cual da a la vida, y al esfuerzo vuelto hacia la razón una dimensión infinita; que la razón señal aquello hacia lo cual el hombre en tanto que hombre tiende en su ser más íntimo, lo único que puede satisfacerle, hacerle 
"feliz"; que la razón no padece por distinguida en "teoría", "práctica" y estética", o lo que se quiera; que ser hombre es serlo en un sentido teleológico -es deber serloy que esta teleología reina a través de todas sus acciones, de todos los designios del yo; que este telos apodíctico puede ser reconocido siempre por medio de la comprensión de sí y que reconocer este telos, comprendiéndose a sí mismo radicalmente, es exactamente comprenderse según principios a priori: es comprenderse a sí mismo según el estilo de la filosofía. (1992, p.141-142)

Husserl habla que en la fenomenología hay trabajos y tareas, entre las cuales se presenta la posibilidad de una antropología filosófica, (Husserl, 1985, p.369) que se construya "enteramente de nuevo sobre la base de la existencia del ser humano" (Ibíd., p.365) una ciencia humana con pretensión de universalidad.

Podría decirse entonces que la fenomenología es una actitud y un hacerse una vida filosófica, es un estilo ${ }^{4}$ de vida fenomenológica, que como ciencia pretende lo universal de la propia vida, que sólo se logra por una tarea constante de conocimiento de sí mismo y del mundo circundante, para así hallar en las vivencias, las esencias que le dan sentido trascendental a la vida misma. La filosofía es de estilos, cada uno forma el suyo de acuerdo a sus investigaciones, a partir de su mundo y de su propio Ego, de alguna manera todos son en su base estilos fenomenológicos, todos parten de la reflexión de su propio yo.

Esta ciencia tiene como centro de reflexión el hombre, su mundo vivencial, su conciencia y todo lo que dentro de su percepción pueda encontrarse, incluso en el recuerdo, la memoria o la historia. Pero no es el hombre en general, no es el hombre sin rostro, es Cristina o Juan Pérez. En palabras de Husserl, se trata de una "ciencia como reflexión racional y radical sobre el mundo y la experiencia humana" (1985, p.373) que cada investigador, expedicionario, principiante o co-principiante realiza desde sí mismo.

Así pues, cuando se hace mención a las esencias en fenomenología, se comprende que es propiamente filosofía, ya que sus problemas se originan puramente en ella y su reflexión parte de la vieja máxima délfica: "conócete a tí mismo", un conocimiento filosófico que es un "autoconocimiento universal" (Husserl, 2009, p.39) Pareciera que las esencias no han

\footnotetext{
${ }^{4}$ Término usado en el epílogo a la versión inglesa de Ideas I. Pág. 376. "La descripción eidética es una división, del estilo total de esta nueva ciencia a priori que hace frente a las ciencias matemáticas..."
} 
podido separarse de la filosofía y la filosofía del hombre. Las esencias son connaturales a su nacimiento y están ligadas a la pregunta filosófica ¿quién soy?

Así como la pregunta por el sí mismo es esencialmente filosofía, las esencias caen en el horizonte filosófico del hombre que se interroga a sí mismo. Es como realizarse "un autoexamen radical" como ejercicio fenomenológico. La esencia es precisamente, lo que está aquí, frente a mi espejo. Es lo que estoy viendo, es eso que ante mis ojos (negros, café, verdes, miel, pardos, azules) acostumbrados cotidianamente a ver de un modo desinteresado, me cuestiona. La esencia es eso que de manera natural está ahí mismo ante mí y de lo cual pocas veces me percato que es lo esencial.

Lo esencial, se me aparece de un modo distinto. Siempre está ante estos ojos que se han acostumbrado a ver mal, con los ojos enfermos de cataratas que nublan la visión, quizá enseñados a ver con lentes oscuros, o lo que es peor, con ojos ajenos.

Pero como en toda tarea, hay que hacer ejercicios. Ejercitarse en aprender a ver, cambiar los lentes, mejorar la vista, ver con un estilo propio. Primero: ver nuestra cotidianidad y los fenómenos que allí estén. Segundo: ver las cosas que están a la vista y verlas como son, verlas en su aparecer esencial. Tercero: ver esas esencias en retrospectiva hacia mí misma.

Las preguntas han dado un giro y requieren ser cambiadas. No preguntamos ahora ¿qué es la esencia? o ¿hay esencia? sino ¿Cuál es la esencia que se me aparece ante la vista en estos momentos? En otras palabras ¿Cuáles son las ideas que dan a la conciencia de lo que veo y vivo en mi mundo circundante? Mi mundo, es donde mi cotidianidad se explaya, donde tiene lugar mis experiencias y donde veo todos sus fenómenos, desde donde percibo las cosas, por el cual veo las cosas y me veo a mí misma. San Agustín es un mundo circundante, entre muchos otros, en el cual he tenido unas experiencias, en el cual veo las esculturas, el entorno y a través de cual me veo como un reflejo.

Husserl por fin me responde: "pero no accidentalmente se me escapó repetidas veces la expresión esencia y esencial, que equivale a un concepto determinado de lo Apriori aclarado por vez primera por la fenomenología.” (2009, p. 28) Cuando llego a la esencia lo que realmente estoy viendo es lo Apriori de toda experiencia. Lo Apriori de mi constitución esencial, de mi verdadera posibilidad de existencia invariable dentro de sus 
variables, multiplicidades y elementos específicos, dados en las vivencias. Ahora se ve más claro... la fenomenología es ante todo una filosofía de lo Apriori. Investigar en esta filosofía, es hacer una investigación de lo a priori, que equivale a decir, una investigación del origen de mi mundo (1962, p. 49), es realizar una fenomenología genética de la vida. De allí que se postule a esta fenomenología como una ciencia auténtica. (1998, p.31)

Si tuviera que responder en pocas líneas a la pregunta de qué es la fenomenología diría: es el estilo filosófico de lo Apriori. Y ello es, según mi afección, una filosofía serena. En la que puedo tener ahora convicción para seguir en el camino de una vida filosófica, que es a la vez el camino de mi propia vida, sin escoger, sin decidirme por una o por la otra como antítesis, sino estando así, aquí, al tiempo en que reflexiono. Husserl me ha quitado ese gran peso de la dualidad.

\section{2 ¿Qué problemas son realmente fenomenológicos?}

Me dice Husserl: "Todos los problemas de la fenomenología son problemas de esencia”. Pero me llega la pregunta ¿cómo surgen los problemas? ¿Están ahí en la esencia? ¿Se me dan o los busco? Ya se han dado algunas puntadas.

Toda ciencia posee un objeto determinado de conocimiento. Pero en la fenomenología, los

objetos no son datos fijos de la experiencia, ella trabaja con fenómenos. Lo que aparece a la vista del investigador no son objetos de conocimiento, sino fenómenos y contenidos de conocimiento.

La cualidad de esos fenómenos es su mostrarse ante los ojos del expedicionario, es este el que con su mirada puede percibirlos como tal. Husserl interrumpe mi diálogo: "Nuestras miradas están puestas, en la fenomenología; aquí, en la fenomenología del conocimiento como doctrina de la esencia de los fenómenos cognoscitivos puros.” (1982, p.58)

En otras palabras, si la fenomenología tiene por problemas aquellos que competen a las esencias, estos solo se encuentran en los fenómenos. Los objetos de la fenomenología son fenómenos que están dados para ser conocidos en su pureza, cuya unidad esencial está en él. Para llegar a los problemas hay que ver el fenómeno que se nos da y en esa investigación encontraremos la esencia. 
Esos fenómenos no son meramente abstractos e ideales, ni solamente concretos. No tienen una forma definida, no se les puede clasificar por su tipo o por su especie; tienen múltiples caras, distintos ángulos, ojos, aristas, texturas, colores, sonidos. Los fenómenos no se encuentran estáticos en el mundo dinámico y tampoco se dan fijos en las ideas. Por tal razón, los fenómenos deben ser de tipo concretos-eidéticos.

La clave está en la dación de esos fenómenos. ¿Cómo se dan? ¿En dónde se dan? El fenómeno aparece de un modo inmediato en el mundo. En un mundo como éste, en un lugar, como en "El País de las Maravillas", o en un "lugar-otro", incluso en una "heterotopía” o en el mundo natural-sensible. Los fenómenos están ahí como una cosa más dentro del movimiento del mundo básico y desprevenido de la cotidianidad.

En ese flujo de las cosas del mundo, bailan los fenómenos a la orden del día, sin que nadie los vea en su aparecer puro. Todos podemos experimentar ese simple hecho de tomar la taza de café, pero basta con tener un ver distinto que me permita acceder a esa cosa como fenómeno cognoscitivo y con ello, verlo de modo puro y eidético, captando la idea que se me aparece de la taza del café que estoy bebiendo, porque "la fenomenología ha de ponerse ante la vida, a título de ejemplares..." (1949, p.148).

La taza de café puede estar en un plato, en un restaurante, en la mesa del sombrerero, en la sala de mi casa quizá..., está dada en el mundo, en un sentido amplio de posibilidades espaciales. De manera natural, tomo la taza de café matutino, percibo su calor, su aroma, su color y sabor. Pero la taza de café simple y corriente, como una cosa cualquiera en un mundo $\mathrm{X}$, cobra importancia al verse como un fenómeno, porque se me da distinto, me afecta con cierta simpatía y me detengo en sus cualidades. Ya no es una cosa que se da, sino un fenómeno dentro de un campo que configura una vivencia específica de conocimiento para mí como investigador.

La taza de café es ese fenómeno concreto, que al percibirlo en una actitud natural, se me da como una simple taza pequeña o grande, de color café, oscuro, clarito, dulce o amargo. Acá la descripción de esa taza, solo me deja ver las propiedades externas de la cosa.

Sin embargo, lo que acompaña el momento de beber aquella taza en la mañana, o en la tarde o en la noche, crea unas variantes de esa misma experiencia, haciendo que sea 
percibida en sus matices, con sus tonalidades particulares, en sus posibles formas de conocimiento, en las significaciones que le otorgo, las cuales permiten sentidos diferentes, que reflexiono sobre mi propia vivencia: "Precisamente la correlación entre vivencia de conocimiento, significación y objeto es la fuente de los problemas más hondos y difíciles dicho en un palabra- del problema de la posibilidad del conocimiento." (Husserl, 1982, p.28).

Husserl empieza a hablar conmigo, y me pide que no me quede sólo en lo concreto del fenómeno, que no me limite a sus determinaciones externas, que es necesario ahondar y profundizar en ellos para captar la esencia de esa vivencia, "por ejemplo llevo a cabo un análisis de tipo experiencia sensible, de cosa espacial; avanzo sistemáticamente en la consideración constitutiva..." (2009, p.28) En el fenómeno debo moverme, porque en él está su constitución esencial, pero el investigador no llega allí de una manera directa, sino a través de la descripción sistemática de ese fenómeno pequeño, avanza en el detalle, en lo microscópico de esa experiencia.

El fenómeno como cosa concreta, no es la esencia en sí, pero a la vez sí lo es en tanto que sus propiedades, la muestran de un modo particular. La taza grande o pequeña de café oscuro, clarito, dulce o amargo, con aroma, caliente, son las propiedades que constituyen la esencia de la taza de café para mí. Pero no es aún la esencia pura, que como investigador quiero captar. Esa experiencia natural me arroja unas determinaciones fácticas, pero hacen falta otras relaciones o como menciona reiteradamente Husserl, la correlación entre conocimiento y objeto de conocimiento $(1982$, p.32) que constituyen diferentes sentidos.

Se trata de ver la esencia de lo que para mí es ese fenómeno que es la taza de café. Lo concreto de ese fenómeno, es necesario para una reflexión sobre vivencias de tipo trascendental, que poseen una significación y un sentido subjetivo e intersubjetivo, que va más allá de lo mediato, constituyendo esencialmente un conocimiento de mi mundo y mi propio yo. Pero ello, solo se logra con un proceso de descripción, de aclaración profunda y de exposición de la esencia, donde es necesario aplicar un método.

Así, es posible ver que el problema de la dación del fenómeno en un mundo, pasa a ser un problema de la constitución del fenómeno en la conciencia de quien investiga. En efecto, la fenomenología tiene realmente como problemas, los de la constitución de la esencia. 
Con lo anterior, es claro que en fenomenología no es posible hablar de datos fijos de conocimiento. En ella, no se trabaja con datos sensibles al modo de las ciencias de la naturaleza, ya que es imposible aplicar ese modelo para el caso de nuestras vivencias y fenómenos de conciencia. Mientras que los métodos tradicionales toman objetos estáticos, despojados de sus relaciones con otros objetos, separados y apartados del mundo, donde el que investiga es quien juzga el objeto externo. La fenomenología trabaja con las correlaciones de los fenómenos en su constante flujo, el modo de su constitución en un mundo posible de conocimiento y el modo de constitución en el sujeto que las percibe y las reflexiona.

Ante la pregunta ¿Cómo surgen los problemas fenomenológicos? La respuesta está latente, se dan en nuestras vivencias dentro de un mundo fenoménico real, en un campo perceptivo, donde es posible dotar de cierto sentido y significado trascendental al Ego que investiga.

En palabras de Husserl "Todo problema trascendental real es un problema fenomenológico" (2009, p.56) Así, vemos llegar el problema. Solo cuando miramos atentamente las cosas del mundo como fenómenos que la conciencia pueda captar, de un modo eidético, trascendental y esencial, es cuando aparecen los problemas de la fenomenología.

Dice Husserl en la tercera lección de la Idea de la Fenomenología, "es cosa manifiesta que yo sólo puedo aclarar la esencia del conocimiento si la veo por mí mismo y si me da a la vista ella misma tal como es" (1982, p.57) nadie puede hacer que veamos la esencia. Es una tarea subjetiva.

Es necesario vivir y experimentar naturalmente, -cosa que todos hacemos- para pasar a un vivir y a un experimentar reflexivo -cosa que empieza hacer el investigador-. Todo es una cuestión de cambio de actitud. Se pasa de una actitud natural a una actitud reflexiva y posteriormente a una actitud fenomenológica. Y en esas nuevas modalidades, el ver se agudiza, el campo de percepción sobre los fenómenos se amplía y en lo profundo, la esencia empieza a parecer sutilmente más clara, cada vez más clara, para ser aprehendida en su sentido más genuino. Es en todo caso, tomar el "conocimiento del sentido y la especie de los problemas genuinos y de las genuinas soluciones." (Husserl, 1977, p.17) 
Así pues, los problemas fenomenológicos están en el fondo de las cosas. Los problemas pueden ser todos aquellos que aparecen como origen en las esencias que la actitud reflexiva va descubriendo, la cual no es nada sin que se alimente de todos los fenómenos que se presentan en la actitud natural.

No habría un problema realmente genuino y auténtico sin la taza de café, pero tampoco habría problema sin la experiencia reflexiva de la taza de café con sus variantes, en la mañana y en la tarde, sin las correlaciones que tiene conmigo esa taza de café que recuerdo haber bebido, cada vez distinta, con cada posible evocación de manera singular.

Aquí el problema aparece. ¿Cuál es la esencia originaria para mí, de esa taza grande o pequeña, oscura, clarita, amarga o dulce, caliente o tibia que mi padre me dona? Y siguiendo la actitud reflexiva, ¿Cuál es la esencia originaria para mí de esa taza de café en la mañana escribiendo este texto, en la tarde dialogando sobre Husserl con el Teacher y en la noche leyendo fenomenología? ¿Hacia dónde me lleva la esencia originaria de esa experiencia trascendental? ¿Cuál es la esencia originaria de esa taza de café que bebo sorbo a sorbo entre palabra y escritura?

El sentido del recuerdo que me llega sobre esa taza de café, es el empezar a filosofar cada día. Es el continuo inicio de filosofar a cada instante, sorbo a sorbo, meditando en lo que pienso, quiero ver y hacer de mi vida, "siguiendo los motivos de la experiencia, inferimos lo no experimentado a partir de lo directamente experimentado (de lo percibido y lo recordado); generalizamos..." (Husserl, 1982, p. 26)

El sentido de la taza de café en la tarde, en medio de unas conversaciones fuera de clases, con compañeros y colegas debatiendo sobre temas de actualidad. Esa taza de café que en ocasiones, en la tarde-noche, puede convertirse en cebada, pero que son el comienzo o quizá la excusa, para sentarme a pensar sobre mi vida y lo que me circunda. Claro es Husserl cuando dice que el problema de la fenomenología es "el problema de la génesis y del llegar a ser” (2009, p.53) el origen de las cosas para el sí mismo y el cómo llegar a ser uno mismo.

Es evidente que en la fenomenología, las vivencias pueden mostrarse de diversas formas, hay una gama infinita de posibilidades, entre las cuales, podrían entrar vivencias de la 
fantasía y la ficción, en palabras de Husserl, "la ficción constituye el elemento vital de la fenomenología, como de toda ciencia eidética" (1949, p.158). Para abordar los fenómenos es también indispensable recrear correlaciones mentadas, libremente en la fantasía.

Quizá los fenómenos que aparecen "en un restaurante cercano... [donde] ...el viento hace que dos vasos bailen por arte de magia sin ser vistos..." (Amélie, min.1:40) o "las páginas llenas de fotos de pasaporte... rotas y descartadas por sus dueños...y cuidadosamente restauradas por un chiflado..." (min., 42:10) Pero ello solo es percibido en el mundo de Amélie Poulain, que se refugia en su imaginación y a través de ella, se pregunta sobre las cosas pequeñas y sencillas de su diario vivir, como por ejemplo ese álbum extraño de fotos que cambiaría su vida, donde aparece un hombre repetidas veces con una expresión fría y plana, que le suscita emoción y la llevan a interrogarse “¿Por qué hacerte fotos por toda la ciudad y después desecharlas? Es como un ritual,” -se contesta, “¡está muerto!”:-concluye. (min., 48:03)

Como en el mundo ficticio de Amélie, los fenómenos pueden aparecer para ser descritos y tomados como problemas que requieren de las preguntas, que no tienen sentido sino para ella que las percibe particularmente como trascendental. Y a partir de ese fenómeno dado de las fotos, su vida misma se vuelve una reflexión y un monólogo constante sobre los detalles del mundo que la rodea.

Problemas sobran y para hacer fenomenología hay bastante trabajo. Hay fenómenos, hay vivencias, pero se necesita determinar el cómo, el dónde y en qué medida, se dan las diferentes vivencias, su esencia y su origen. Así, los fenómenos que tenemos a la vista en este instante no son solamente de la experiencia sensible sino que están en el intelecto del que las percibe constantemente de distinta manera, según su sentido subjetivotrascendental, de lo que significan universalmente para el yo singular.

Todas las preguntas vitales de mi Ego, todas las cosas del mundo, todas las cosas de la conciencia de la vida, de la "obviedad de mi propia experiencia, a partir de mi propia conciencia de la vida, en ella está la fuente de lo que para mí tiene sentido como hechos del mundo de algún modo objetivos" (Husserl, 1985, p.373) y es esto, lo que llamamos fenómenos trascendentales o vivencias fenomenológicas. 
Todos estos fenómenos, son vivencias sobre las cuales la conciencia reflexiona, y en ellas también aparecen en la fantasía, los recuerdos, las ideas o los sueños que al hombre le significan algo. El objeto de conocimiento de esta ciencia, son las múltiples experiencias que tenemos cada uno de nosotros en nuestra vida, en aquel transcurrir por este mundo.

Incluso, pienso ahora, en la posibilidad de tomar como vivencias de reflexión fenomenológica los actos, el arte, la música, la poesía, el cine, el recuerdo, los sentimientos, las pasiones, la voluntad, dentro de muchas otras vivencias trascendentales. Recuerdo la tarea más difícil que he tenido que realizar para una clase: hacer una descripción fenomenológica sobre el amor, -dijo el profesor Barbosa. Tarea que empezada hace un año sigo sin terminar, continúo viendo sus variantes y voy cambiando línea tras línea, borrando y reescribiendo, en la medida en que reflexiono sobre mis vivencias, sus correlaciones y detalles.

El trabajo puede ser infinito, quedará siempre por fuera algo, quizá nos puede durar toda la vida. Por ello, un ejercicio filosófico de este tipo, implica un acto de convicción. (2009, p.29) No es solo tomar una decisión, sino un estar convencido del hacer fenomenológico, de su constancia y reflexión, a la hora de elegir nuestros fenómenos trascendentales.

De cualquier forma, las vivencias esencialmente puras y trascendentales, nos abrirán un campo eidético, lleno de múltiples ideas, infinitas relaciones, diversas constituciones internas y externas, un dominio eidético multiforme sobre el cual labraremos un sendero fenomenológico. Así pues "se abre un amplio reino de posible investigación" donde podemos trabajar "todas las preguntas teoréticas, prácticas, todas las preguntas decisivas" (1985, p.373) que nos sean vitales y que nos muevan trascendentalmente.

De este modo, los problemas fenomenológicos están en las vivencias trascendentales de cada sujeto. Pero esas vivencias solo se hallan en referencia con un mundo inmediato de la experiencia, no es el vivir por el vivir mismo desinteresado, sino el tener una vivencia en correlación con el mundo que me circunda y en el cual proyecto mis intencionalidades. El mundo mismo va determinando las propiedades externas de mi vivencia, y a su vez se van tejiendo posibilidades de sentido con el sujeto-investigador que interroga con cierta intención, con un interés de reflexión. 
La emoción se ha tomado el discurso y se hace necesario ver surgir otro obstáculo ¿Por dónde empezamos el trabajo fenomenológico? Siguiendo la pregunta de Husserl: “¿Cómo encontrar el justo punto de partida?" (1949, p.145) El objeto que tenemos es el de las esencias de nuestra vivencias dentro de nuestro mundo, esas esencias allí ubicadas, son las que nos proporcionan un campo de conocimiento eidético. El objeto de conocimiento no es el mismo, así, el método para proceder debe ser uno adecuado al tratamiento de esos fenómenos, un método ajustado a las cosas mismas.

Sin embargo, el fenomenólogo puede tener infinitos ejemplares singulares, pero su proyecto filosófico, apunta a un solo Apriori que le dará sentido y contenido a sus vivencias. Ese Apriori, cada principiante debe descubrirlo, es su mayor problema fenomenológico encontrarlo, el comienzo está en él mismo.

\subsection{Todo es cuestión del método fenomenológico}

Pero nadie puede regalarnos el método; solo podemos obtenerlo mediante la profundización, en el sentido de los problemas, y obtener los problemas de trabajo más determinados a partir de los determinados. (Husserl, 1977, p.18)

No hay un recetario del método fenomenológico, ni de su aplicación. Este solo aparece cuando voy investigando en profundidad los problemas y cuyo proceder hace que la esencia se me vaya manifestando.

Los problemas me van indicando, de alguna manera, el modo en que deben ser abordados. Según sus facetas, me van diciendo cómo es su abordaje, cómo redondearlos, cómo tratarlos, en definitiva, el método está determinado por los problemas que hallo en la investigación, apareciendo a la vez que se me va dando el fenómeno, cuando van surgiendo los problemas, al tiempo en que se vislumbra el sentido, todo como parte de un simultáneo proceso.

Es preciso tener en cuenta, que se trata de realizar una investigación libre, tanto en la elección de nuestro fenómeno, como en el ver que enmarca mi reflexión fenomenológica. No es un trabajo de repetición de lo que otros han dicho sobre mi objeto y tampoco es la copia de un modelo metodológico que fuerzo a ceñirse a mi interés. Es por el contrario, 
abrir la posibilidad para que el expedicionario elabore su propio camino de reflexión y excave en detalle el problema a partir de sus determinaciones.

Este método consiste en tomar los fenómenos y entrar en sus problemas para "leerlos y releerlos sobre todo, [porque] de sus oscuridades afluirán para nosotros, porque podemos separar motivos y capas, miles de incitaciones, aun ahí donde no podemos aprender de ellos, donde no podemos tomar teoría de ellos.” (Husserl, 1977, p.18)

Los problemas no los veo de inmediato, se me presentan oscuros y esa dificultad hace necesaria la aplicación de un método para su esclarecimiento. Debo despejar capa por capa, quitarle las marañas, limpiarlos, pulirlos y verlos esencialmente.

Pero no es tan sencillo como parece. La esencia se me da, es propio de las esencias el dársenos, el aparecérsenos y el método se hace patente cuando hay algo dado. No es posible iniciar una investigación sin la elección de un objeto ya visto. Y en fenomenología, el método no aparece después de ver mi fenómeno, es gracias a él que yo lo percibo como fenómeno de mi conocimiento. Fenómeno y método van apareciendo paralelamente.

Desde el mismo instante en que tengo la vivencia de una primera vez con mi objeto, allí ya está implícito el método. Sin embargo, en ese momento inicial, aún no hay una reflexión sobre su aplicación, porque es en el ejercicio del recordar, del retrotraer, del ensoñar, del ficcionar, que puedo hacerlo.

El método me permite ver a los ojos de la conciencia la esencia, para que en ella sea posible aprehender puramente su eidos más universal e invariable, pero ¿por dónde debo empezar para ver ese objeto de conciencia? Me enfrento al problema del comienzo, Husserl me da una pista, partir de un modelo guía, por tal motivo vuelvo a un recuerdo y lo describo como parte de una vivencia que he percibido como mía, y desgloso minuciosamente todas las relaciones con el espacio y el tiempo en el que he encontrado mi objeto de estudio, tomándolo como un ejemplar singular para desde allí realizar la descripción fenomenológica.

Libremente puedo escoger la danza como mi fenómeno, sí, aquel gusto que me ha acompañado desde niña, lo tomo ahora como objeto de reflexión. Se me aparece como tal en un recuerdo, en la percepción, en los modos de dárseme subjetivamente, y que al tratar 
de leerlo y verlo en sus posibilidades, en su vaguedad, en sus diferencias, se me hace imposible escapar a sus determinaciones más visibles.

Rememoro cuando estaba en el taller de Escenafro (danza afro y teatro) y era mi primera vez en ello, veía a mi profesor chocoano moverse al ritmo de los tambores que se interpretaban en vivo, seguidamente, mi cuerpo respondía a lo que veía. Pero los fuertes movimientos no los reflexionaba, no me preguntaba cómo los estoy haciendo mientras los hacía. El cuerpo fluía como una reacción natural, la respiración se agitaba y los muslos palpitaban, las articulaciones prometían desplazamientos, pies que saltaban, brazos que se estiraban, torso articulado, todos eran contenidos de las vibraciones de los cueros... pero solo ahora que lo recuerdo, logro describirlo en mi percepción, solo en este instante, puedo despejar lo que hacía, y con ello veo llegar las preguntas: ¿Cuál es la esencia de la danza? ¿Qué es el escenafro? ¿Por dónde comencé el movimiento? ¿Cómo surgió la fuerza? ¿Cómo se me dio el ritmo? ¿Qué sentido tiene danzar?

En el desarrollo del movimiento del cuerpo, no tengo la conciencia del método que usé para ello. Y al querer repetirlo nuevamente de la misma manera, la coreografía no es la misma, los pasos nunca serán idénticos al de la primera vez, el compás empieza a variar y hay que comenzar de nuevo. Eso mismo sucede con el método fenomenológico, no se tiene claro cómo se usó mientras se usaba. Husserl nos dice que ello se logra, "mediante la elaboración sistemática del método que pregunta retrospectivamente por los últimos supuestos concebibles del conocimiento.” (1949, p.373) En este caso, los cuestionamientos posibles del conocimiento de la danza, por cuyo método se empieza a tejer sus últimos supuestos.

Es ahí, en la ejercitación del recordar, como un traer del pasado, como una retrospección o como una acción retroactiva ${ }^{5}$ del cómo se hizo el movimiento, el paso, el esquema, las cuadrillas, donde se encontrarán aquellos aspectos invariables que irán a consolidar las pautas del método. Describiendo paso a paso, pieza a pieza, exhaustivamente, ese estar danzando, ese danzar, ese $1,2,3, . .1,2,3 \ldots$ Primero trayendo a la memoria el pie que salta, los brazos que se alzan, la cabeza que acompaña la cadera, todos sus elementos concretos,

\footnotetext{
${ }^{5}$ Término usado en Ideas I, §65 pág. 147-149 nombre del epígrafe: la referencia retroactiva de la fenomenología a si misma.
} 
para ir capturando el sentido de la danza como un universal, a través de la exposición de un particular como el Escenafro, que es también aquí, parte de una experiencia trascendental.

El bailarín no reflexiona sobre su movimiento, lo perfecciona en el ensayo. No se pregunta por su esencia, por la posibilidad de su corporeidad y tampoco por el conocimiento último de la espacialidad del cuerpo. No se preocupa por el método para llegar a la esencia de su arte, sino que aprende la técnica y la historia que debe aplicar en cada ritmo. Por ello, este quehacer es filosófico e implica ese cambio de actitud frente a las experiencias. Husserl habla: "Fenomenología designa un método y una actitud intelectual: la actitud intelectual específicamente filosófica; el método específicamente filosófico” (1982, p.33).

Es por ello, que el método fenomenológico se da y se comprende en la medida en que hago filosofía, en tanto voy describiendo el objeto que se me ha dado como la danza y que ahora como fenómeno la veo como tal, porque me afecta, la siento mío, la apercibo como inserta en mi yo, de eso se trata ese gran giro del que hablan los fenomenólogos, "el giro a la subjetividad trascendental", que es mirar desde mi Ego esa percepción de la danza, aquello que es para mí lo importante de la cosa. Porque "todos los análisis reflexivos, son análisis fenomenológicos esenciales y las evidencias intelectuales logradas acerca del método están en lo que respecta a su propia comprobación sometidas a las normas que ellas mismas formulan”. (1949, p.149).

Las normas de este método, solo se hallan en la evidencia y claridad intelectual, que se obtiene de la reflexión de esencias. No siempre son las mismas esencias, por tanto, tampoco son las mismas evidencias, y las normas del método varían de acuerdo a esos problemas que van surgiendo.

Es necesario estar en los problemas para entender el método, estar dispuestos a entrar en las cosas mismas, porque ese entrar es un camino, es una marcha, un hacer constante, un hacer propiamente filosofía, donde "todo lo desconocido es en este caso horizonte de algo conocido" (Ibíd.,p.146) y es difícil decirle no, a nuestro propio Ego, aún más, cuando este no deja de preguntarnos, y más cuando Husserl nos introduce en ese querer profundizar en las esencias dadas en nuestras vivencias. 
Ante todo hay que estar en el campo de la vida; sí, sencillamente vivir, experienciar, andar, divagar, leer, danzar. "empezamos nuestras meditaciones como hombres de la vida natural, representándonos, juzgando, sintiendo, queriendo, «en actitud natural»" (1949, p.64), danzo en una actitud natural, pero no danzo para quedarme en ella, de tal manera que la vida misma no se duerme en el desinterés filosófico. En una actitud natural siempre estamos como humanos existentes, pero para el ejercicio fenomenológico es necesario no quedarse allí, en un deslucido estar ahí en el mundo, sin saber cuál es el ahí, cuál es el mundo en que se vive y cuál es la luz que le da sentido.

Aunque toda reflexión fenomenológica parte de ese estar en actitud natural, hay que avanzar en grados de profundidad, para caer en cuenta de nuestra propia vida, a través de esas preguntas que le dan sentido. Si estoy practicando Escenafro, avanzo no en la técnica, sino en la reflexión de mi propia vida, a partir de esa vida natural y por medio, de los interrogantes filosóficos.

Presto atención a las pequeñas cosas que vivo mientras sigo viviendo naturalmente, y al hacerlo, el espectro de mi visión se amplía, mi ver deja de ser intuitivo e inmediato y pasa a ser llamado por el objeto que me seduce afectivamente, donde todo se empieza a ver cada vez más claro, donde cobra un significado distinto el mundo, aunque siga lavándome los dientes.

Lo más difícil es saber por dónde comenzar y Husserl lo reconoce. "lo primero es naturalmente examinar cómo podría encontrar el comienzo absolutamente seguro y el método de la marcha faltándome todo apoyo de la ciencia pre-dada.” (2009, p. 4) Aun no sé si la pregunta por la esencia de la danza sea un buen comienzo, es el riego que se toma al hacer una auténtica filosofía. Así pues, tendré que meditar sobre ese posible comienzo seguro de investigación y dada esta dificultad, es necesario no fallar en el intento de nunca encontrar un camino sin un piso firme, que me permita cumplir con la clave de trabajar sin teorías.

Como requisito, tengo que ver, pero solo veo realmente cuando caigo en cuenta, y propongo "sencillas consideraciones...en primera persona" (1949, p.64) Cuando abro los ojos, aunque esté despierta frente a lo que voy viviendo, de cara a mi mundo, tomo a modo 
de ejemplar singular ${ }^{6}$ una cosa que la intuición llama mi atención (la danza) aquello de lo cual tengo la certeza que he experimentado directamente (Escenafro) y metido en ella, empiezo a describirla en primera persona, des-cubriendo todos los elementos que aparecen a mi vista.

Aunque no lo haya contemplado en ese mismo instante en que danzaba, ahora que la tomo como fenómeno, ya han aparecido simultáneamente varios elementos metodológicos. 1) Vivir en la actitud natural, danzar. 2) Tomar a modo de ejemplar una cosa singular de ese vivir, el Escenafro 3) Estar atento a lo que se me da intuitivamente sobre la cosa vista, para hacer una descripción en primera persona. Con ello, evito caer en teorías y voces de otros, asistiendo en definitiva a una "actitud escéptica".

La actitud escéptica, la desarrollamos desde niños, la perdemos en la adolescencia y nos la exigen en filosofía, es simplemente tener esta admiración infantil $7^{7}$ sobre las cosas que nos rodean, pero que deben ser explicadas fenomenológicamente. Es un dejar de lado, poner lejos de la mesa de reflexión todo lo que se ha dicho frente a mi objeto de estudio, arrumarlo en una pila de papel, mientras me dispongo a comenzar un trabajo fenomenológico. El juego consiste en un dejar... para comenzar de nuevo, un iniciar propio, originario y difícil.

Esta actitud no hay que dejarla ir, porque constituye la base de toda la filosofía, y por ello se debe "persistir en esa infancia fenomenológica" (Husserl, 2012 p. 42) de admirarse y preguntarse por las cosas que nos rodea, es ser un niño pero a la vez un adulto. En otras palabras es preguntar pero renunciando a la ingenuidad, de creer lo que se dice de mi objeto, no permitir que los susurros de otras teorías me impidan acercarme plenamente a él. "La nueva fenomenología ha de contar, pues con un básico estado de ánimo escéptico." (1949, p.146).

\footnotetext{
${ }^{6}$ Expresión mencionada en $\S 66$ de Ideas I, pág. 150. "Sobre la base de una intuición bien ejercitada de ejemplares singulares, se las provee, pues, de significaciones claras y únicas."

${ }^{7}$ Término que utiliza Helmunt Plessner, para explicar su experiencia como estudiante de Husserl en Gotinga y en especial del novedoso principio de "a las cosas mismas".
} 
Renunciar a la ingenuidad de que el mundo es mundo sin más, o que es el mundo y las cosas según las ha establecido una tradición, para entender que ese mundo es mi mundo, aquel en donde yo vivo y por el cual pienso y veo lo demás. No puedo experimentar directamente el mundo con la mirada de otros, con un percibir ajeno, con un pensar o con un querer extraño. El mundo es posibilidad, todas sus realidades "deben ser tratadas como posibilidades entre las posibilidades, justamente como posibilidades arbitrarias de la fantasía." (1980, p.388).

El bailarín tiene sus opiniones frente a lo que entiende por danza y variarían las definiciones según el ritmo, la técnica y la escuela que profesen. Sus significaciones estarán atadas a teorías de otros bailarines que han tratado de darle contenido teórico a su quehacer o quizá basados en la ficción de algún seudo-bailarín que hace crítica artística.

Pero todas esas palabras y visiones hay que poner [las] entre paréntesis, (1985, p.371) “«borrando», por así decirlo, las otras significaciones que en ciertas circunstancias se ocurren primero por obra del hábito.” (Ibíd., p.150) Aquellas convicciones fijadas en el común o presupuestos que se han dado como válidos por su historia, o por la multitud que las justifica a través de la tradición, quizá todas las teorías de disciplinas que nos dan definiciones aparentemente fijas y últimas, "me abstengo de toda toma de decisión respecto del ser y la ilusión" (2009, p.8) sin dar juicios o valorar lo dado. Todas las ciencias y los conocimientos previos hay que también suspenderlos.

Poner entre paréntesis consiste en un apartar de mi vista el mundo, su validez y sus contenidos previos. Es dejar en el cajón las teorías, los juicios científicos, morales, estéticos, cualesquiera que sean, pero separarlos del campo de excavación. Es dudar de su ayuda, mirar con sospecha sus resultados y argumentos, los cuales impiden que sea una principiante en filosofía. No es eliminar esos contenidos y llevarlos a la papelera, ni tampoco es reciclarlos. No es un negar para olvidarlos. Sino un dejarlos mientras tanto...

Es un tomarlos pero no tomarlos a la vez. Ello se hace cuando realizo mi descripción, de un modo gradual, por niveles de complejidad, quitando capa por capa, detalle tras detalle y no todas a la vez. Iniciando por las capas exteriores, por las más visibles, sin tomar las teorías, pero mirándolas poco a poco para confrontarlas luego con mis propias menciones. 
Esa actitud escéptica, hace que ponga entre paréntesis todos esos supuestos que obscurecen mi objeto y que no le permiten dárseme plenamente como mi fenómeno. No puedo creer en esos pre-juicios porque no tengo certeza de ellos, simplemente por no haberlos percibido como parte de mi vivencia y por lo cual aún no son claros para mi conciencia, y aunque suene obvio, en la academia no nos enseñan a hacer esto, sino siempre debemos basarnos en teorías y autores, como Yo en este trabajo, de lo cual también quiero escapar en otras páginas para hacer una reflexión propiamente fenomenológica.

Por lo pronto, todo lo que acompaña a mi objeto de estudio en contenidos y significados es puesto en cuestión, lo que en equivalencia es un preguntar. No es musitar una simple duda, sino una interrogación que me permita abrir el portal esencial de mi problema. Es la pregunta inicial, la que generará la descripción de mi fenómeno. La primera que dará sus intuitivas respuestas inmediatas, las que indican el camino para continuar la marcha.

Si he experimentado la danza a través del movimiento, y lo he descrito según la percepción que he tenido de él, debo dudar de lo que las teorías dancísticas han dicho al respecto, poniendo entre paréntesis incluso lo que los teóricos de la literatura han estipulado como verdad, sospecharía además de los discursos que definen la danza, poniendo en cuestión también la definición del atractivo profesor chocoano: "la danza como un desfogue de energía”. Por tal motivo, surge en mí la necesidad de preguntar ¿Cuál es el sentido de danzar? ¿Cuál es su Apriori? ¿Cuál es el a priori para mí que la reflexiono? Estos cuestionamientos son los que se realizan ante cualquier ejemplar que tomemos para un hacer fenomenológico.

La importancia de esa pregunta está en que debe ser universal y radical. Su dirección debe apuntar a la clarificación de la esencia de mi fenómeno. Una pregunta que posibilite dar menciones ${ }^{8}$ quizá afirmaciones "válidas" por el momento, pero que no lleven a tomarlas como evidencia verdadera y absoluta, no como sus pre-conceptos, sino que permitan un diálogo entre mi Ego y el fenómeno, una correlación que refiera a la actualidad de mi vivencia, cuyas proposiciones enuncien de manera cercana, el estado en que experimenté

\footnotetext{
${ }^{8}$ Término usado reiteradamente por Husserl en Conferencias de París. Pág. 23.
} 
mi objeto y el modo en que me experimenté a mí misma en relación con él. Ambos movimientos del mismo trabajo fenomenológico. La danza dándoseme y yo dándome a la danza, en mutua correspondencia y reflexionadas en la conciencia.

Este escepticismo estará presente en todo el desarrollo de mi descripción. Permitiéndome estar atenta a la cosa en su pureza. Al poner entre paréntesis mi objeto, escucho atentamente lo que me dice, ¿Qué dice la danza?, así puedo entrar en conversación con él, ¿Qué veo en ella? ¿Cómo escucharla?

Solo cuando soy escéptica de mi propio estado natural, me puedo detener en ese recuerdo o anhelo, que se presenta como en cámara lenta, viéndome mientras la veo, estando frente a ella, detallándola en retrospectiva, como el flashback de una película, me veo danzando y me veo ahora escribiendo sobre ella. Y estando despierta, puedo intuir la pregunta que me lleve a ver la esencia de la danza como parte de mi reflexión. Pregunta que apunta a sus estructuras invariables y peculiares, que en el mundo natural se presentan variables y multicolores. Finalmente es la pregunta por el Apriori de estas. (Husserl, 1949, p.378)

Pero esa pregunta inicial es el resultado de mi primer ver el objeto en mi conciencia y será la que guiará la descripción de mi objeto. Esa pregunta pone de manifiesto el problema de nuestro objeto desde el cual se empezará hacer toda la reflexión. Y con ello ya estamos asistiendo a una "reducción fenomenológica". Porque mediante ella "se fija la mirada en el yo trascendental y se hace de él, el tema de una descripción trascendental.” (1949, p.380).

Es aquí, cuando decidimos realizar la famosa epojé, que implica un ejercicio, no un instrumento, para abrir las posibilidades infinitas de mi fenómeno, que juega a ser visible e invisible, baila entre ese aparecer y desaparecer. No hay que perder de vista que también en este ejercicio debe estar explícito mi sentido frente al objeto.

Pero es importante prestar atención a la advertencia que Husserl nos hace: "Si se yerra el sentido de la reducción, que es la única puerta de entrada en el nuevo reino, entonces se yerra en todo." (1985, p.372) Los peligros son muchos, pero a quien no le gustan los retos. Las preguntas me abren la puerta al problema, pero también lleva a posibles respuestas. Sin 
embargo, para que sean realmente tenidas en cuenta en la descripción deben ser claras y evidentes.

Con ello he experimentado una desconexión, entre mi experiencia natural del mundo fáctico y la experiencia trascendental, entre la principiante en Escenafro y la principiante en fenomenología. Aquella desconexión, implica que el yo que experimenta las cosas de la cotidianidad en ese dejarse vivir naturalmente, en el que percibe un cambiante y variable mundo, con sus determinaciones propias de la extensión, en la que juzgo según mis gustos, apetencias, disgustos, odios etc., pasa a un Ego que se experimenta así mismo, como un ser consciente de sus percepciones y consciente del objeto que ha tomado como reflexión. Objeto ahora de mi conciencia, donde realmente mi propio yo pasa a ser el objeto de mi reflexión, en tanto es en él, donde hallo el sentido del ahora fenómeno interior.

La desconexión radical es hacer el salto de la actitud natural a la actitud fenomenológica pasando gradualmente por una actitud escéptica y reflexiva donde se pone en cuestión la cosa, es la llamada auto-desconexión del fenomenólogo 9 . Se habla es de un mismo yo que nunca se separa de sí mismo, pero que tiene la capacidad de vivir en estadios graduales de profundidad.

Nos hemos desconectado de nosotros en tanto seres naturales, dejando a un lado todo aquello del mundo simple, para comenzar nuestra reflexión, pero siendo siempre conscientes de que no dejaremos de ser humanos, no dejo de ser cuerpo, el mundo no deja de existir, soy consciente de que debo trabajar, realizar unos quehaceres domésticos, sigo degustando el café, pero a la vez vivo trascendentalmente en el problema de mi investigación. No hay que dejar nuestro objeto, sino explicitarlo, mencionarlo "en conceptos al hacer una descripción" teniendo ahora una "conciencia teorizante en sus diversas formas y grados." (1949, p.66)

Aquí, es cuando aplicamos la norma de la reducción fenomenológica a nuestras vivencias naturales, que ya no pertenecen al mundo de la dispersión, de lo ligero, del día a día, sino que pasan al mundo de mi yo trascendental, cobrando sentido "implícitas o

\footnotetext{
${ }^{9}$ Vale aclarar que no se debe confundir esta desconexión fenomenológica con el dualismo Cartesiano. Donde el sujeto se puede separar en res extensa y res cogita, donde el uno es antítesis del otro.
} 
explícitamente". La reducción entonces, no solo se da en el fenómeno de mi conocimiento sino en mi propio yo como sujeto consciente de mi hacer fenomenológico, como si participara de una auto-reducción.

Es necesario desconectarnos porque de lo contrario, no podemos acercarnos al sentido que tiene el mundo para nosotros. "Podemos, incluso, seguir hablando tranquilamente como debemos hablar en cuanto hombres naturales;...no hemos dejado de ser hombres naturales...pero como parte del método,...nos damos la norma de la reducción fenomenológica." (1949, p.147)

En la fenomenología no es posible desligarse del objeto de estudio, ya que abordarlo implica siempre una conversión de sí mismo. Así como el fenómeno lo reducimos a sus ideas, convirtiéndolo en un fenómeno de un orden más esencial, asimismo sucede con el principiante que ejerce la reducción: "la conversión es conversión de un individuo en un segundo individuo incompatible con él en la co-existencia."(1980, p.382).

Esa conversión no es una lucha entre dos individuos. Ambas facetas son una misma unidad pero en conflicto. El objeto no deja de ser fenómeno fáctico con sus determinaciones al tratarlo eidéticamente, de la misma forma que el investigador no deja de estar en una actitud natural al convertirse en una actitud reflexiva. Ambas son momentos que el expedicionario debe ejecutar sin dejar de ser una unidad.

En esa actitud reflexiva trabajamos eidéticamente y ya no naturalmente nuestro fenómeno. Si como primer nivel tenía la condición de la actitud natural, donde describía libremente las determinaciones externas de mi vivencia con aquel ejemplar singular del Escenafro. En la segunda escala me hallo en la actitud escéptica, cuestionando esas variables fácticas y formulando preguntas que indiquen caminos de investigación. En esta tercera fase me pongo en actitud reflexiva, y la descripción ahonda en las ideas que van surgiendo de las preguntas y de las determinaciones externas de la danza, así todas ellas son disposiciones especiales para "obtener los conceptos puros o conceptos de la esencia” (Husserl, 1980, p.376).

Es en esa actitud reflexiva donde nuestro ver debe re-direccionarse, dirigiendo la mirada hacia nuestros objetos ya no físicos sino fenomenológicos, nuestras vivencias se tornan 
puras, depuradas de sus realidades materiales. Si vivencio la danza-afro, ahora, me enfoco en la experiencia reflexiva que tiene esa idea de la danza, la idea de lo afro, la idea de su movimiento, la idea de su desplazamiento, la idea de ponerse en escena, etc. Como variaciones libres, ¿pero qué significa ese fijar la mirada? Es tematizar.

Si tengo una actitud reflexiva, iniciada con las preguntas propias de un escepticismo fenomenológico, focalizaré un tema de mi descripción sobre esa vivencia natural. Pongo el ojo en algo peculiar que me suscita universalmente conocer mi fenómeno, y ello es realizar un acto intencional, necesario para el trabajo trascendental que se sigue, es decir se realiza la tematización del fenómeno.

No me interesa lo afro, ni el acto teatral, ni mi profesor chocoano, mi intención es hallar la esencia de la danza como un universal para mí. Siempre debo ir caminando hacia esa esencia, así voy pisando en el campo eidético, donde con la nueva mirada me retrotraigo a mi conciencia y allí veo mi fenómeno para describirlo. El campo que se me muestra ante esa nueva mirada intencional me es propio, es en él donde mi investigación cobra sentido y rigor científico. En aquél prado se me abren las posibilidades del fenómeno.

Entrando al nuevo reino, cambiando de actitud, preparado el terreno, surge como fruto de este cambio de visión las primeras conceptualizaciones trascendentales, "fijamos las esencias intuidas por medio de conceptos o términos" (1949, p.150) que corresponden a la forma actual de lo dado. Que "cobra un sentido determinado que es su claro sentido actual." (Ibíd).

Ese concepto o término, puede ser tomado del mundo coloquial, vulgar ${ }^{10}$, cotidiano o especializado, filosófico o antifilosófico, erudito o ignorante, quizá perteneciente a otras disciplinas, pero que co-relacionan el sentido cambiante de mi vivencia con la esencia, expresados en términos unívocos.

He fijado la mirada, ya no es importante las variantes iniciales de la facticidad, sino las ideas que tengo de ellas, y mientras las sigo viendo debo ir aclarándolas para hallar el

\footnotetext{
${ }^{10}$ En Ideas I, Pág. 150, § 66: Sobre, fiel expresión de datos claros. términos unívocos.
} 
concepto más general, más puro y esencial entre ellas. Una reducción ya no de las realidades exteriores, sino de las posibles ideas, una reducción eidética.

Recordemos. Parto de un modelo guía ${ }^{11}$ o ejemplar singular, el Escenafro, que abre una multiplicidad de variantes según la descripción de sus capas más visibles, la danza, lo afro, el teatro, los brazos, los pies, la cadera, el ritmo, el desplazamiento, la corporeidad, el gesto, .... Al realizar esas variantes, algunas arbitrarias, de la pura fantasía, ficciono otras, no tan visibles y materiales como las primeras, que se relacionan entre sí; pero en la actitud reflexiva; la idea de lo afro, la idea de desplazamiento, la idea de la corporeidad, la idea de la danza... Mientras las veo intelectivamente, esas variaciones eidéticas, "se conservan por necesidad en una invariante." (1980, p.377) que no es más que "un contenido absolutamente idéntico, como un qué invariable, conforme al cual coinciden todas las variantes: esencia general... esa esencia general es el eidos" (Ibíd.) en este caso es el: danzar.

Pero esa esencia general o eidos, que se menciona a través de un concepto, no se da por sí solo. No es por necesidad del fenómeno sino por necesidad en la correlación "esencial general entre realidad y posibilidad, entre experiencia y fantasía pura.” (Ibíd., p.391) es aquella unidad que se obtiene de los modos múltiples en que se me da mi fenómeno en la descripción. Husserl lo diría mejor:

Si por ejemplo, partiendo de un sonido, ya sea que realmente lo escuchemos o que lo tengamos como sonido en nuestra fantasía, obtenemos lo necesariamente común aquí, el eidos "sonido", aprehendido en la modificación de variantes arbitrarias. Si tomamos como punto de partida otro fenómeno sonoro, como variado al arbitrio, no aprehendemos con este nuevo "ejemplo" otro eidos "sonido", sino que en la yuxtaposición del nuevo y del anterior vemos que es el mismo,.. que las variantes y variaciones aquí y allá son del mismo modo particularizaciones arbitraras de uno y el mismo eidos... en la forma de la arbitrariedad tiene que resultar "siempre de nuevo" el mismo eidos: la misma esencia general "sonido en general". $\left(1980\right.$, p.378) ${ }^{12}$

Si danzar y sonido son el eidos que se obtiene de sus respectivas reducciones, sobre ellas se alza otro nivel de investigación fenomenológica que tiene que ver con la ideación o

\footnotetext{
${ }^{11}$ Término usado en Experiencia y Juicio Capítulo II.

${ }^{12}$ Las cursivas y comillas están en el texto original.
} 
contemplación de ese eidos. Si el eidos era hacia donde se encaminaba la descripción, el método no se agota, y ahora su mayor particularidad será este eidos encontrado, el método de la marcha ${ }^{13}$ continúa.

En esta reducción de mayor complejidad, es donde se hace patente un proceso de ideación. Ese paso se da con la variación o variantes, que "estriba justo en que abandonemos la identidad de lo individual y la transformamos ficticiamente en otra individualidad posible." (1980:385) Podría imaginar otro ejemplar que no fuera el Escenafro, como la danza contemporánea, el currulao, un torbellino, quizá un taller de Urban dance, y aunque la lista continúe, entre todas ellas está la misma invariable: danzar. Danzar es el Qué, el What, el Was, el Qu`est-, “conforme al cual coinciden todas las variantes” (Ibíd., p.377) es éste la mismidad que une los fragmentos percibidos en la actitud natural y el que resulta de las preguntas dadas en la actitud escéptica.

En el proceso de la ideación la multiplicidad de variaciones de nuestro fenómeno en tanto fáctico se va agrupando en unidades eidéticas según sus coincidencias y luego se van identificando y diferenciando unas de otras, según la posibilidad infinita de sus ideas correspondientes. El método permite libremente que se den proposiciones, menciones, posibles ideas de la idea general, lo importante es que "los conceptos utilizados se ajustan con efectiva fidelidad a lo dado." (1949, p.149) sin desligarse de la experiencia individual.

Puedo idear el danzar como un actuar, actuación de algo, pero ello se ajustaría mejor al teatro. El danzar es un ritual, ¿un ritual ancestral? Tal vez, como el que realizaban los danzantes del monte Albán en el imperio Azteca, danzando en círculos alrededor de un tambor cilíndrico considerado de origen divino, y que se interpretaba al desnudo, como lo dejan ver las piedras talladas de aquél lugar sagrado. ${ }^{14}$ Pero no es ese el sentido que veo, es una ceremonia sí, un momento ritual entre parejas, bailarines, músicos y espectadores, que se conjugan en un solo espacio. ¿Ritual de qué o para qué? Podría decir que es un ritual de encuentro. No es el encuentro con amigos en el "Goce Pagano". La danza es encuentro ¿Con qué o con quién? ¿Entre mundos? ¿Entre el pasado y el presente? Para el Grupo de

\footnotetext{
${ }^{13}$ Término usado en Conferencias de París para definir el método fenomenológico. Pág. 4.

${ }^{14}$ Beltrando- Patier, Marie- Claire. (2001) Historia de la música. España: Espasa- Calpe. Pág-1018-1020.
} 
Tumaco, la danza es un encuentro con los ancestros, quizá con espíritus vivientes, pero eso solo aplicaría para la danza folklórica, indígena y afro-americana. Para otros puede ser un encuentro con la esperanza, un encuentro con la libertad, con los sentimientos o simplemente para compartir y disfrutar.

Sí, danzar es un encuentro, pero para mí es un encontrarse consigo mismo, que a través del movimiento, el cuerpo, el ritmo y la cadencia, se juntan de una manera ceremonial. Pero ¿Cuál es la correlación allí?

Aquí está efectuándose la norma de la clarificación de la esencia. "Una teoría del conocimiento genuina tiene que ver exclusivamente con el esclarecimiento de la obra del conocimiento" (2009, p.33) Husserl, describe en qué consiste esa norma de la clarificación, por un lado tiene que ver con la forma en que se aprehende claramente la esencia y por el otro en la forma clara de exponerla conceptualmente "ya [que] toda aclaración es un evidenciar" (2009, p.23).

Claridad y evidencia. Claridad de la esencia obtenida: la danza es encontrarse. Describir ello conceptualmente, para que sea una evidencia intelectual que posteriormente será expresada, expuesta, exhibida. Así pues, en este método: "La esencial referencia de la fenomenología a sí misma se revela en que lo que se pesa y fija en la reflexión metodológica bajo los rótulos de claridad, evidencia intelectual, expresión, etc.”(1949, p.149) Si por clarificación del eidos danza, tengo entre las posibles una claridad intelectual: la danza es encontrarse, entonces es necesario expresarla y exponerla como evidencia.

Aunque con el eidos se creía tener una unidad idéntica en la conciencia, su pluralidad se hace visible nuevamente, al entrar a contemplarla y hacer la ideación. Una multiplicidad ya no al nivel de lo factico sino al de la conciencia. En la medida en que continúo con esta contemplación, pareciera que me alejo y me acerco, me pierdo y me encuentro con mi esencia. No se deja asir plenamente. Por momentos en la abstracción, la esencia no es idéntica a sí misma, se torna conflictiva, a veces con un mínimo común denominador, otras con un máximo común diferenciador. 
No es culpa de la esencia el aparecernos a veces obscura, ni de nosotros por no verla con la claridad que la amerita, sino por la dificultad de aprehenderla en la correlación. Por tanta luz, se nos puede velar: así como cuando el artista quiere revelar la película fotográfica de su vieja cámara de 35 milímetros y la deja a plena la luz del día, perdiéndose toda imagen que había sido capturada y quedando nuevamente en la oscuridad al que lo lanza el inicio de cualquier foto. Así sucede con el ejercicio de la clarificación de la unidad eidética: danzar, que se ha visibilizado como actuar, como rito, como ceremonia, como encuentro o como encontrarse, todas estas menciones en conflicto, unidades de lo concreto incompatibles unas con otras pero necesarias para la contemplación de la esencia.

Se tratar de contemplar la esencia o contemplar lo universal que se me han dado y en esa medida su aprehensión debe clarificarse para que sea evidente en la correlación eidos Ego, danzar - Yo. Pero no hay que confundir ese contemplar como un estar pasivo ante la esencia, esperando en la esquina de siempre a que aparezca con un chasquido, sino que se trata de un auto-experimentar ${ }^{15}$ activamente las semejanzas y las congruencias frente a las diferencias que he asido en mi visión mental.

Existen diferentes grados de claridad de las esencias y sus relaciones esenciales, es decir, que la norma de la clarificación tiene niveles, de lo más oscuro a lo más claro. "Se trata pues de traer a la perfecta claridad de una cercanía normal lo que en el caso flota en una oscuridad fugitiva dentro de una menor o mayor lejanía intuitiva.”(1949, p.151) Ello indica que en cada visibilidad o invisibilidad está la esencia que se nos aparece cada vez más diáfana. El juego consiste en un mostrarse que vuelve a ocultarse, a la vez que se nos da puramente se nos vela su sentido, ese movimiento entre lo lejano y lo cercano sucede en este proceso de ideación o contemplación de la esencia.

En la oscuridad también hay niveles de sombra y en ella se puede aplicar la norma de la aclaración, incluso cuando la conciencia dice no ver nada por su completa lejanía, cuando afirmamos "no saber nada de cierta esencia", ya tiene algo de ella, que es su incomprensión. Siempre se nos da en sí misma la esencia de ese objeto de conocimiento,

\footnotetext{
${ }^{15}$ Explicación que aparece en el $§ 88$ de Experiencia y Juicio: Sentido de la expresión: “contemplación” [Erschauung] de las generalidades Pág. 385.
} 
no en un darse vacío donde habita la nada, sino en un darse algo confuso. A ello la fenomenología le llama tener procesos puros de conciencia.

Lo que sucede es que la conciencia le pone una disposición al eidos que se ha aprehendido. Todos los objetos de conocimiento fenomenológico están ahí “en disposición de ser percibidos" (1949, p.153) pero es la conciencia la que por intencionalidad no los toma o los deja, para asirlos de cierta manera.

En el proceso de aclaración o clarificación se deben arrojar también las menciones, sobre lo no-claro en el proceso de la reducción fenomenológica, que lleven hacia evidencias posibles. Las menciones actúan como una transición o gradación de lo más oscuro a lo más claro siendo lo menos claro la mención y lo más claro la evidencia.

Es importante tener en cuenta que para esclarecer las esencias e idearlas, existen dos caminos: la aclaración que busca volver lo más obscuro algo intuitivo y la aclaración que consiste en ir de lo intuido a aclarar eso que se intuyó. Acá es cuando la conciencia debe estar atenta para no caer en intuiciones impuras, que nos muestran lo que no es la esencia, sino más bien que en cada aparición y claridad hay una evidencia más. Este método "ha de proyectar sobre el sentido y el valor de este método la más completa claridad, una claridad en que pueda hacer frente a todas las objeciones serias.” (1949, p.146).

Se trata de "poner en la mención no lo mentado como posibilidad de sí sino algo distinto." (2009, p. 23). Es Ver mejor que antes, ver mejor que la primera vez. Si en la danza he aclarado que es un encontrarse, este encontrarse debe verse mejor, no como en sí mismo puro, sino como la posibilidad evidente de ser algo distinto. Ello es tener una visión extractiva de lo universal. ${ }^{16}$

Lo mencionado siempre es una mención de sí mismo, es una mención del sentido propio de la subjetividad trascendental, lo que hace "mantenerse-asido lo recorrido" es la intencionalidad de esa visión que lleva a expresar con palabras simples, en un lenguaje que indican algo cercano a lo evidente y que sea posible verificarlo en la subjetividad trascendental, donde realmente tiene sentido lo mencionado.

\footnotetext{
${ }^{16}$ [Herausschauen] es la expresión en alemán que Husserl usa para designar visión extractiva de lo universal, En: Experiencia y Juicio §89 Pág. 186.
} 
El "encontrar-se" es, en este ejemplar, la evidencia del danzar, pero es necesario mostrarlo claramente. Ello se ha vuelto concepto del eidos y requiere ser explicitado, por tanto el encontrarse se da con el cuerpo, en un acto ceremonial entre mi yo y la corporalidad. Sin embargo, se pueden dar distintas menciones, inclusive contradictorias entre sí, con el fin de ir cuestionando también esas evidencias que van apareciendo y van aclarando u ocultando la esencia. Aunque las evidencias parecen claras son susceptibles de ser criticadas, según el modo subjetivo de dárseme, sus diferencias, sus relaciones, lo que es llamativo, lo que captura mi atención, o lo que lleva a mi desorientación.

Cuando estamos ejecutando la norma de la claración también se va dando la norma de la evidencia y de su mostración descriptiva, a la vez que aclaro el eidos general, voy dando menciones que posibilitan una evidencia, y de estas se exhiben sentidos trascendentales, menciones que son "correlatos particulares de mi propia intencionalidad" (2009, p.24).

Es así como "las posibilidades de verdades, el análisis crítico de las evidencias, clasificándolas, según el rango de su perfeccionamiento y alcance” (Ibíd., p.42) hacen parte del proceso de ideación o contemplación de esencias, donde las evidencias primeras y las que preceden, se dan en el análisis intencional de las menciones más pertinentes, es esa la mediación por la cual puedo tener la evidencia pura del eidos. Entre todas las posibles evidencias y sus posibles sentidos para mi Ego, hallar el concepto más amplio y real de la esencia, donde está la verdad de vida, su Apriori.

Se ha dejado una pregunta del caso abierta: ¿Cuál es la correlación entre ese encontrarse del danza con la corporalidad? El análisis continúa, y la evidencia debe ser puesta en cuestión. Ello se logra con el análisis crítico de las evidencias. Donde las evidencias de un orden superior sujetan a las demás dadas en la aclaración.

Realizando una detallada reflexión sobre las meditaciones de René Descartes en la primera lección de su sinopsis para la edición Alemana de sus "Meditaciones Cartesianas", Husserl plantea que "El filósofo que comienza, habiendo derrocado a las ciencias, no tiene semejantes verdades, pero sí evidencias y verdades de la vida. Empieza con el principio de juzgar con evidencia pura y con el análisis crítico de la evidencia misma respecto de su perfección y su alcance.” (2009, p.42). 
Así pues hay que ver el alcance y perfección de ese juicio evidente del encontrarse con la corporalidad, que puede conceptualizar el danzar como generalidad de la experiencia singular del Escenafro. Pero ello aún sigue siendo una extensión del eidos danzar, es una esencia genérica. La pretensión de este método es ir hasta el concepto universalmente puro, la invariable más invariable, la unidad ideal de sentido del mundo de la vida concreta.

Es así, que el danzar como encontrarse así mismo, se cuestiona nuevamente en miras a la correlación intencional de la vivencia. Críticamente, puedo mencionar que esa evidencia, no corresponde cuando el danzar implica un salir de la cotidianidad, no como un encontrarse sino como un alejarse, un desconectarse del mundo y de sí mismo, siendo presa únicamente del movimiento y el ritmo sin sentido. En otros casos el danzar posiblemente sea un resistirse a lo cotidiano, hacer algo distinto por el hecho de ser distinto. El danzar a veces es un aprender algo. Sigo mi intencionalidad y encuentro que el danzar es también aprender, ¿a qué? a encontrarse. Y ¿cuál es la correlación?

El modo en que aprendo libremente cualquier cosa esta mediada por algo. Algo me permite aprender, conocer, descubrir. En el caso de la fenomenología ese medio es el método, es el camino por el cual aprendo a hacer fenomenología para aprehender las esencias. En el caso de la danza, aprendo a danzar a través del lenguaje corporal, para aprehenderme subjetivamente en ese encontrarse. El danzar entonces es lenguaje. Es el lenguaje del encontrarse.

En todas las correlaciones que se hacen de una esencia general encontrada, están presentes las formas de mundos concebibles, posibilidades libres del fenómeno y los actos intencionales de mi subjetividad trascendental. En este caso la conceptualización del danzar con sus posibilidades; ceremonia, rito, encuentro, con el acto intencional el encontrarse. En medio de ellas se encuentra su correlación verdadera, universal y concreta, a saber, el lenguaje.

Ha llegado el momento del método de la exposición y declaración de la vivencia trascendental, en retrospectiva desde mi ego trascendental. "La posibilidad de estas investigaciones dependen de la comprensión del método de investigación correlativa de 
retro-preguntar desde la intencionalidad en forma concretamente develadora." (Husserl, 1985, p.376).

Exponer y declarar. Estos son las fases últimas del método. Aunque todo lo dicho en este apartado ha sido un exponer el método fenomenológico y ha sido un declarar una posible esencia. El método de la marcha es también el método de la declaración, desde sus comienzos ha sido paralelamente lo uno y lo otro. Pero en este instante se expone y se declara la unidad esencial de la vivencia encontrada en el ejercicio de la crítica de las evidencias y la posibilidad de la experiencia trascendental.

Danzar es lenguaje, yo como danzante entro en diálogo con mi corporalidad me encuentro con él, implicando un conocerse en el movimiento coreográfico y el ritmo. Mientras se ejecuta el baile ese lenguaje va expresando algo, se hace expresión de sentimientos, de sueños, de historias, de miedos, de luchas, de vida, etc. Solo a través del lenguaje se puede expresar algo, con él se realiza un verdadero encuentro. Y la danza tiene su propio lenguaje, donde se dicen múltiples cosas que varían de acuerdo al baile, al contexto en que surgió, a la música que lo interpreta, etc.

Así pues, encuentro cómo en esa unidad esencial se explicaran todas las diferencias, las contradicciones, las menciones hechas, allí están las variantes, los otros posibles ejemplares singulares de esa vivencia y en él se incluyen también las cosas puestas entre paréntesis. Este es el Apriori de la esencia. "La relación esencial general entre realidad y posibilidad entre experiencia y fantasía pura [así] se tiene abierto el camino al reino de la posibilidad ideal o pura y con ello, al reino del pensamiento Apriori” (1980, p.391).

La extensión conceptual, danza es lenguaje, ha de contrastarse con la extensión empírica posible de cualquier danza en la facticidad. Es decir, que se debe llegar a ver, que ese Apriori corresponde a la realidad de la danza particular e individual de toda vivencia posible del danzar. "Toda realidad dada a través de la experiencia y juzgada a través del pensamiento experiencial, se halla, en lo que toca a la legitimidad de tales juicios, bajo la norma incondicionada de que debe corresponder a todas las condiciones Apriori de la experiencia posible y del pensamiento experiencial posible” (Ibíd., p.391). 
Toda la multiplicidad que incluyen las verdades claras y evidentes de la esencia y sus variaciones es Apriori, es decir "que en su validez preceden a toda la facticidad, a todas las confirmaciones derivadas, de la experiencia.”(1980, p.390) Lo que indica que realmente, lo que se halla como sustrato y fundamento de toda vida natural, es el concepto universal de las cosas que la conciencia de quien investiga ha encontrado. Aquel comprende que todo lo que ha intuido en sus meditaciones y contemplaciones no es sino las cosas mismas del mundo concreto.

En ese volver a la experiencia, no dejamos las ideas, ni las esencias, ni las menciones, ni las evidencias claras, sino que la "visión de las ideas es ella misma un análogo de la experiencia simple, en cuanto que es una conciencia desde luego superior y activamente productora en la que llega a darse por sí misma una nueva objetividad, lo universal.” (Ibíd., p. 398).

Se ha llegado a las cosas. Si pensábamos que todo este quehacer fenomenológico no era más que idealismo, eso hay que ponerlo entre paréntesis. Es un objetivismo en tanto parte de las cosas mismas y llega a las cosas mismas. Parte de los objetos concretos y llega a su objetividad. Parte de una experiencia real y concreta, llegando a la explicación real y concreta del mundo de la facticidad. Pero todo ello lo une un lazo, que permite conectar el todo; la subjetividad trascendental. Podría decirse que este hacer es un objetivismo trascendental.

Y sin embargo, el método nunca se agota. La mirada no se cansa de ver las cosas. El currulao, el break dance, un pasillo, unas sevillanas, un baile afrocontemporáneo, cualquier ejemplar, puede ser tomado como lenguaje. En todos se danza y por tanto todos ellos pueden llegar a ser representados y comprendidos como un lenguaje. Es mi unidad universal de sentido, aquí y ahora. En este momento, porque sobre el tiempo y el espacio del presente es donde tiene sentido construir el Apriori.

De la misma manera que se hace con el fenómeno, sucede con el investigador. Se vuelve variable, es múltiple, halla algo aparentemente fijo como evidencia, halla la esencia, su Apriori y llega a ser trascendente. Pero luego, vuelve a la realidad fáctica y se da cuenta que no ha dejado de ser parte del mundo, sigue siendo cambiante, variable, presa también de lo inmanente. Confronta lo que ha encontrado en sí mismo con otros percatándose que 
es una subjetividad entre muchas subjetividades. $\mathrm{Y}$ en esa intersubjetividad, mis convicciones fijas encontradas en el método fenomenológico pueden volver a ponerse en cuestión. La pretensión de mi Apriori, sigue siendo posibilidad de ser otra cosa, en poderlo representar como algo fijo e inmóvil, pero en el futuro es posible que sea algo distinto, en constante flujo.

Con el método encontramos las esencias, el Apriori, que "los conceptos empíricos, no son especificaciones reales de generalidades puras; más bien significan generalidades típicas, campos de acción experienciales, que esperan de la experiencia real una pre-indicación cada vez nueva." (Ibíd., p.404).

La danza como lenguaje, seguirá siendo por este día un Apriori esencial de toda experiencia real cuando me halle interpretando o viendo una obra dancística, pero a la vez será potencialmente susceptible de ser objeto de otra reducción. Así, pues, es gracias al método fenomenológico, a la reducción eidética que es posible ver la esencia y llegar a estipular variables invariables que a su vez será tomada como variable de otra investigación fenomenológica. Solo a través del método se hace realmente fenomenología.

\section{4 ¿Cómo es posible una reflexión latinoamericana desde el método fenomenológico?}

La fenomenología me ha llevado a ver la posibilidad infinita de fenómenos y reflexiones que, a partir de su método, pueden labrar un camino para un hacer filosófico latinoamericano. Tal pretensión podría sonar para algunos como un reto, para otros algo antifilosófico o quizá sería visto como una contradicción, por tomar un método de la tradición y abordar fenómenos latinoamericanos. Allí estaría el debate y con él la puerta abierta para un hacer filosofía en su sentido más amplio, más universal, el de ir a las cosas mismas que están esperando por algún expedicionario en la aventura filosófica de pensar el mundo circundante. Y ello es, sin nombrarlo, una actitud fenomenológica sobre mi mundo latinoamericano y colombiano, próximos a mi mirada.

Es por ello que recuerdo la preocupación del Doctor Germán Vargas Guillen: ¿y qué de nuestra historia? Yo preguntaría ¿y qué de nuestro mundo? realizamos investigaciones 
sobre grandes autores de la historia de la filosofía, pero sus libros y sus vidas nos agobian en universos ajenos y extraños para la comprensión de nosotros mismos. ¿Dónde quedan las cosas de mi mundo? Ellas siguen esperando en el lugar de siempre, al que nunca vamos y al que pocas veces vemos con la mirada filosófica. Pero acaso ¿no es eso lo que hace un filósofo? Su hacer inicial es mirar el mundo inmediato que se le presenta, su labor es habitar ese mundo y las cosas que allí se encuentran, "su arte es sobre todo infinito y en la vista de su infinitud, que ha llegado a ser tarea para la vida" (Husserl, 1930, p.29).

El mundo latinoamericano tiene en sí cosas, problemas, sueños, fantasías, cuentos etc. Cualquier ser que aquí habite y esté, experimenta de cierto modo lo cotidiano, su propia vivencia, su vida misma. El mundo es lo dado mediato. Y en él todas las pequeñas cosas tienen un sentido, es sobre él que las palabras significan algo, donde lo que hacemos expresa un sentir singular y trascendental.

Leo a Husserl, camino con Husserl, veo gracias a Husserl, pero él se queda en la mesa de trabajo y con un guiño me dice: "buena suerte en la subida" "saludo de los montañistas cuando están en el camino" (Ibíd., p.31) mientras tanto, sigo andando en este sendero que elegí de la filosofía, donde cada paso se da a modo de profundización, donde la fatiga de la escalada se siente en el descenso hacia el interior de las cosas. Se sube a lo profundo.

Por ello Husserl nos invita -como a su estimado alumno Dorion Cairns- a seguir nuestro propio trabajo filosófico y fenomenológico, comprendiendo que su vida y obra "no presentan resultados para ser aprendidos, sino fundamentos para que cada uno construya por sí mismo. Se trata de métodos para construir por sí mismo y solucionar problemas por sí mismo...si quiere llegar a ser filósofo, pues se es solo y permanentemente llegando a ser y queriendo llegar a ser." (Ibíd., p.31).

Esta es la mayor enseñanza de Husserl como profesor de filosofía. Todo cuanto se lee y se escribe es para otros, posibles fundamentos para hacer auténtica filosofía y ser filósofo en forma constante. Por tal razón, le hago una seña de campesino para perseguir mi montaña de oscuras selvas y senderos distintos, que aparecen en este hacer reflexión filosófica latinoamericana, mirando el horizonte del método fenomenológico. 
En ocasiones evitamos el tema de lo latinoamericano, y con ello eliminamos de antemano, toda posibilidad de hacer filosofía desde Latinoamérica. Quizá porque suscita dudas, preguntas y sospechas, dejándola en manos de otras ciencias como la sociología, la antropología, la historia o tal vez, la arqueología... es como si el propio mundo estuviera vedado para el filósofo.

Se sabe también en nuestro medio actual, que la filosofía no tiene buen nombre cuando se trata de hablar de realidades concretas y más aún, sobre eventos singulares del mundo inmediato. Tal fue el duro artículo publicado por la revista Arcadia en el 2011 con su título ¿Dónde están los filósofos? -En la Torre de Marfil, fue la respuesta. Esto quizá originado en la vieja idea mal repetida de asociar la filosofía con una pasividad contemplativa, donde se niega todo, incluso al propio ser pensante, el cual vive en su burbuja de fantasía abstracta sin contacto con el mundo de lo cotidiano. No es extraño por tanto, que sea vista por algunos contemporáneos como un "desempleo" perjudicial para el progreso empresarial de un país y cuya solución de emergencia hace que el Ministro Wert proponga en una reforma educativa, "la eliminación de dos de las tres asignaturas de Filosofía de la enseñanza secundaria”, aprobada irrefutablemente por el gobierno español.

Muchas otras posturas ven a la filosofía como un no- hacer o un dejar de hacer algo. Sin embargo, ya se hablado, que por el contrario, la filosofía es un hacer. Propiamente un hacer es un oficio, una labor es activa, expedicionaria, marcha en el camino de la investigación, escala, excava profundizando en las cosas, muestra lo buscado, visibiliza una posible cara del mundo natural y cotidiano, nunca se aparta de lo concreto. En definitiva un arduo trabajo que toma toda la vida, siempre desde lo que se me presenta en el mundo de mis vivencias.

La clave para acercarnos a este mundo ya la sabemos, cambiar de actitud, y ver posibles horizontes de sentidos y significados propios, ideas originarias, reflexiones auténticamente filosóficas, que impliquen trascendentalmente al investigador sobre su aquí; sea desde experiencias políticas, éticas, artísticas, literarias, musicales, lingüísticas, mitológicas, etc., pero que en todo caso escudriñe y profundice en posibles esencias del presente desde el método fenomenológico. 
Pero esta idea no es nueva. Ya existía un interés por la fenomenología en Latinoamérica. Según Daniel Herrera: "El surgimiento de este interés se debió, en primer lugar, al movimiento de traducción de obras filosóficas, movimiento alentado inicialmente por Ortega y Gasset y posteriormente por editoriales mexicanas, lo cual permitió a los latinoamericanos, que no dominaban lenguas extranjeras, el acceso al pensamiento contemporáneo.” (2010, p.1).

Nombres como Joaquín Xirau, Juan David García Bacca y José Gaos realizaron trabajos de traducción de obras filosóficas de Husserl y Heidegger. Libros como Las investigaciones lógicas (1929), Ideas I (1949), Meditaciones cartesianas y El Ser y El Tiempo entre los más importantes (Sobrevilla, 1994, p.2). El surgimiento de este interés se debió entonces al movimiento de traducción, que permitió acercarse a esta línea de pensamiento hacia la década del 30.

Para el caso específico de Colombia, hay varios nombres que hicieron su propia lectura del pensamiento de Husserl. Quizá no fue solamente las traducciones de los libros lo que llegó, sino la recepción de un estilo diferente de filosofar en Colombia. Es el caso de Luis Eduardo Nieto Arteta, que hacia los años 40 utilizó la fenomenología para tratar la experiencia jurídica, buscando en ella la esencia del derecho, mientras se ocupaba de cargos públicos y famosos reconocimientos. Su trabajo investigativo consistía en encontrar esas posibles esencias que estructuraran la experiencia de cada ciudadano sobre la justicia. Donde la idea de lo justo correspondiera a la vivencia de la justicia en el mundo, una manera "vital racionalizada y racional vitalizada.”(Herrera, 2009, p. 292).

Ese uso de la fenomenología que curiosamente no empieza a ser tomada por filósofos, sino por historiadores y politólogos como Nieto Arteta, pionero en hacer una recepción del pensamiento de Husserl, dadas su lectura de Investigaciones Lógicas, como fuente principal, y las obras de Gurvitch y Celms, como fuentes secundarias.

Sin embargo, tenía muchos otros intereses que oscilaban entre la economía, la política y $L a$ persona humana y la vida ${ }^{17}$, este último especialmente resalta su hacer filosófico cuyos

\footnotetext{
${ }^{17}$ Título del texto de Luis E. Nieto Arteta. Actas del Primer Congreso Nacional de Filosofía (Mendoza 1949), Universidad Nacional de Cuyo, Buenos Aires 1950, tomo II, págs. 1069-1078.
} 
ejemplos estaban trazados por eventos de la cotidianidad natural de cualquier persona y dejaban ver en su simpleza discursiva, argumentos filosóficos complejos referentes a la libertad o la necesidad de la vida, en el cual no ve una contradicción sino una unidad relacionada, recurriendo a casos como: "el hombre y la mujer que o contraen matrimonio o permanecen solteros, el estadista nombrado para un alto empleo o lo acepta o lo rechaza, el comprador de una casa o paga el precio o se niega a pagarlo, el autor de una obra o resuelve publicarla o la entrega a la "crítica roedora de los ratones", etc. La multiplicidad es indefinida. O lo uno o lo otro, pero inexorablemente algo, alguna decisión.” (1949, p.1070).

Lo que indica que no sólo era una recepción de ideas y conceptos, sino el estilo fenomenológico de tomar el método de la descripción de esencias y la reducción fenomenológica de casos concretos y cotidianos. Algo evidente en el texto citado de Arteta, donde es posible explicar este problema a partir de cosas situadas: "Cuando fuimos invitados a concurrir a este Congreso teníamos que decidir si asistíamos o nos absteníamos de concurrir. El decidir, era la libertad, pero el "tener que" decidir una cosa o la otra, era la necesidad". (Ibíd.).

Ese aquí del Congreso, o de los ejemplos de la vida natural para tratar asuntos filosóficos seguramente vino luego de leer a Husserl en Colombia y por supuesto seguiría la tendencia fenomenológica del Círculo de Gotinga y posteriormente del Círculo de Friburgo, donde se enfatizaba la descripción de esencias lógicas y formales, y en la aplicación del método de la reducción fenomenológica a casos concretos de la realidad.

Con esta interpretación, Rafael Carrillo definió la fenomenología como "una disciplina filosófica auxiliar" (Herrera, 2002, p.8) con la que era posible abordar el derecho desde una perspectiva axiológica, tomando como centro de reflexión el derecho, aplicándole la reducción fenomenológica y encontrar en él, los valores que permiten a las personas realizarse existencialmente y de manera fundamental. El derecho vendría a significar para Carrillo ese "algo que el hombre hace para hacerse así mismo, y al hacerse a sí mismo constituye el valor de una persona" (2009, p.293).

Lo más importante de Carrillo, además de su gusto por leer -hacia las diez u once de la mañana- la prensa mientras tomaba un café “en la cafetería del Hotel continental de la 
avenida Jiménez con cuarta" (Cataño, 2012, p.5), fue el haber realizado una reducción axiológica, para fundamentar que los valores son la base de la existencia de las personas, y que éstas -al preguntarse por sí mismos- llegan directamente a la idea del derecho. Este interés le era propio por su afición a comprar libros de ciencias humanas entre los que ponía en primer lugar a la filosofía, seguida de "la historia de la cultura, derecho, sociología, literatura y algo de política.”(Ibíd.).

Con una vida austera, una máquina de escribir y un radio donde escuchaba sus compositores alemanes, los libros ocupaban su tiempo y la filosofía su propia vida. Afirmando que, "no es en ratos perdidos que podemos entregarnos a la filosofía: debe olvidarse todo para dedicarse a ella. Nunca será suficiente el tiempo que se le consagre. Abandonarla un instante, es abandonarla completamente". Ese era su hacer constante de querer ser y llegar a ser filósofo, en medio del café que "era la ocasión de aproximarse a los demás, de hacer amigos, intercambiar ideas y discutir sobre libros, autores y temas del momento.” Por ello, su vida y la fenomenología eran activamente un mismo hacer.

En esta dirección se hacen lecturas sobre la relación entre el mundo y el hombre con su existencia. Problema que tiene que ver con la llegada de la idea del Lebenswelt y del concepto de vivencia. En medio se presentan juegos constantes, entre lo que pienso sobre el mundo y el sentido que le da el mundo a mis pensamientos. En esta correlación ambos se explican; "Ver en la reflexión cómo la realidad se me hace presente en el torrente de mis vivencias y cómo mis vivencias en la variedad de formas- percibir, imaginar, recordar, amar o desear- constituyen una manera determinada de yo hacerme presente a la realidad y una manera determinada de hacérseme presente la realidad.” (Herrera, 2002, p.15).

Para Daniel Herrera, la fenomenología también puede ser tomada como analítica de la conciencia, que hace parte de la segunda etapa de interpretación dada especialmente por uno de los asistentes de Husserl: Eugen Fink, quien hacia los años 40, luego de la lectura de Ideas relativas a una fenomenología trascendental y una filosofía fenomenológica (1913) afirma que, “el problema central de ésta fenomenología es ... la génesis de este mundo [que] no sería otro que la actividad constituyente de un Ego trascendental.” (2002, p.9) lo que se interpretó como un pensamiento solipsista, donde el sujeto llega por 
abstracciones a verdades trascendentales de corte metafísico y un Yo universal que se tradujo como un Dios creador.

Esta última interpretación, que subraya Herrera, fue la que tomaron en Colombia en los años 60, para trabajar con una fenomenología cuya característica era ser un idealismo puro y radical. Así lo recibió el llamado filósofo colombiano del siglo XX: Danilo Cruz Vélez, quien rechazaría categóricamente a este Husserl y preferiría lanzarse a los brazos del pensamiento heideggeriano.

No obstante, en lo que más va a enfatizar Cruz Vélez, es en la idea husserliana de una filosofía $\sin$ supuestos $^{18}$, aquella que dictamina una forma particular de filosofar para pensar y hacer fenomenología sin teorías y poner entre paréntesis los supuestos bajos los cuales nos hemos formado o deformado un cierto conocimiento del mundo. Es necesario destruir los supuestos de objetivismo para que tengamos nuestra propia filosofía.

Así nos referencia Herrera lo que dice Cruz Vélez en un fragmento de Filosofía sin supuestos: "También nos interesaba ponernos en claro sobre nuestra propia labor filosófica. En el camino histórico que hemos recorrido pudimos liberarnos de muchos ídolos y ver con claridad, desde el centro que ofrecía nuestro tema de fondo, las líneas maestras de la filosofía occidental. Y sobre todo, logramos adquirir clara conciencia de la situación de dicha filosofía en la actualidad, que es, queramos o no, nuestra propia filosofía." (2009, p. 297).

Esta tesis, generó un intenso debate filosófico en la época entre quienes no confiaban en esa posibilidad de una filosofía despoblada de supuestos o una filosofía pura y primigenia que algunos, junto a Cruz Veléz confiaban en su posibilidad. En efecto, veían en Husserl la realización de un yo puro que conoce el mundo y a la vez un yo real que hace parte de ese mundo, que lo convierte en un yo impuro.

Esa contradicción husserliana hace que el posible proyecto de una metafísica de la subjetividad que habla del ser del hombre, caiga en la impureza propia de las cosas del mundo. A pesar de que Husserl nos lanza a un nuevo reino donde la conciencia se habla a

\footnotetext{
18 Título de su obra más importante, publicado en el año 70.
} 
sí misma y el hombre trasciende en la universalidad, aclara que ese YO trascendental y esa conciencia universal es solo posible en un yo particular, el Yo sólo es posible en el horizonte inmanente del mundo de la vida con las cosas y en las cosas.

La relación inmanencia y trascendencia, es la misma que hay entre el YO trascendental y yo individual, entre un idealismo y un materialismo. Ambos hacen parte de un mismo y único proceso. Pensamos en humanidad en tanto seres de carne y hueso, en tanto nos afecta el mundo y somos parte de él. Reflexionamos con ideas sobre cosas que hay en nuestro mundo.

Hablamos de una nueva imagen del Yo. No es un ser netamente idealista alejado de la realidad, ni tampoco un ser netamente materialista que olvida la reflexión. Es un nuevo hombre que está en el Lebenswelt y que a partir de ese mundo, reflexiona para dar sentido a aquel y a sí mismo.

Como mundo de la vida, la fenomenología se expresa en el horizonte de todo lo que nos circunda, que de manera presente, pasada o futura da algún sentido. El Lebenswelt tiene sentido porque está bajo el horizonte de la temporalidad. Reflexionamos sobre el mundo de la vida al contener todo lo que nos acontece, lo que nos sucede actualmente, más la actualidad no la tenemos, es un esfuerzo fatuo. El ahora, no es posible tenerlo como fenómeno, al ser inasible y al escapársenos en el instante en que queremos aprehenderlo.

La única forma de tener el ahora es recordándolo como un pasado -a través de la memoriao como un todavía no, que recae en la expectativa o en la especulación futurista. Sin embargo, es necesario que yo me cuestione ese mundo de la vida que deviene en infinidad de "ahoras" y de "no-ahoras". "Detrás de este pasado retencional inmediato, es también, el pasado liquidado que como horizonte abierto es consciente en cierto sentido y el cual se puede dirigir la mirada, es decir, un reino que se puede volver a despertar en el recuerdo. Por otro lado, tenemos un horizonte abierto al futuro lejano e infinito, el cual se dirigen nuestros actos futuristas, sospechas y esperanzas, previsiones, resolución y fijación de metas.” (Herrera, 2002, p.18).

De allí surge la tercera etapa de interpretación husserliana, que en Colombia tiene nombre propio -en palabras de Herrera, el colombiano que tiene el conocimiento más amplio sobre 
Husserl- Guillermo Hoyos. Él traduce Crisis, Ideas II, entre varios textos aun no transcritos al español de la llamada Husserliana. En su tesis doctoral: "La intencionalidad como responsabilidad", asume la idea del Lebenswelt, para explicar el ámbito ético que tenemos todos por el hecho de participar en una idea de humanidad, que queremos que se realice de cierta manera.

La teleología es la realización de un proyecto universalmente idealizado que se motiva o alimenta de lo que acontece en el mundo de la vida. A la que todo hombre aspira en tanto YO trascendental, como parte de una misma historia, un pueblo, una lengua, un territorio, etc., y donde es posible darle un sentido trascendente a nuestra existencia intersubjetiva, con otros que también quieren y buscan ese propósito común.

Guillermo Hoyos, enfatizará en esa idea de Husserl al decir "ser hombre es serlo y tener que serlo en forma teleológica" (2002, p.300) No basta con ser conscientes de nuestro mundo sino de tener que serlo, al ser consciente de que estoy en el mundo con otros que me rodean y que tiene por tarea cumplir alguna una meta necesaria.

La recepción actual de Husserl en Colombia además de Guillermo Hoyos, con su última tesis del 2011, "Los intereses de la vida cotidiana y las ciencias", donde destaca la importancia de la cotidianidad de la vida natural en relación con la ciencia y la técnica, por otra parte, Daniel Herrera con sus reflexiones "Sobre la persona y la democracia". Germán Vargas Guillen, “que sin abandonar el marco de la fenomenología eidética y sin recurrir a los datos de las ciencias naturales, investiga la posibilidad de una "naturalización de la conciencia por los caminos de la Inteligencia Artificial” (Herrera, 2002, p.20).

Otros que siguen estos caminos son, Julio Cesar Vargas con su "Estudio de la vida psicológica en Edmund. Husserl", Carlos Eduardo Maldonado, con "Introducción a la fenomenología a partir de la idea de mundo", Ana Patricia Noguera con "Identidad y diferencia en la fenomenología trascendental".

Existen otros expedicionarios que siguen reflexionando a partir de todas las variantes de la fenomenología y que son posibilidad de hacer filosofía desde y para Colombia dando luces y perspectivas en el camino de un pensamiento desde Latinoamérica, bajo el horizonte de 
la fenomenología, sea desde sus conceptos o a partir del método, pero cuyo fin es hacer filosofía del mundo de la vida, de nuestro mundo de la vida.

Dentro de los más reconocidos en Latinoamérica actualmente están Roberto Walton, quien problematiza la epistemología desde la fenomenología, Julia Iribarne que realiza una fenomenología de la violencia y tiene intereses de ver la literatura desde la fenomenología, Lester Embree, quien se ha especializado en hacer una historia de la fenomenología en toda América. Todos ellos generando ejercicios de traducción, recepción y apropiaciones distintas, escribiendo conforme a sus vivencias filosóficas.

En la medida en que existan textos en nuestro idioma y apropiaciones de los conceptos a realidades concretas, se hace filosofía y la recepción de Husserl o de cualquier otro fenomenólogo, genera nuevos análisis y estilos fenomenológicos de las realidades latinoamericanas y colombianas, cuyo camino transitado deja ver frutos para continuar en ellos.

Me pregunta un profesor escéptico de esta filosofía: ¿para qué Husserl y la fenomenología en Latinoamérica? Responderé sencillamente que depende de lo que nos pueda interesar de él y de su fenomenología y que permita investigar cualquier tipo de fenómeno latinoamericano que implique nuestra propia existencia. Para eso es Husserl, para pensarnos en el mundo circundante de la vida y su fenomenología o la de cualquier otro, es siempre la posibilidad abierta y libre del hacer filosófico desde la propia vivencia de quien filosofa.

Como método, podría interesar captar realidades, obras de arte, arquitecturas, esculturas, que en las experiencias del latino, con sus cotidianidades múltiples, llenas de riquezas culturales, se tomen como invariables momentáneas, que llenen de sentido el estar en este tiempo, y lugar del mundo desde el cual hablamos, vivimos y sentimos.

Tenemos para este análisis todo un horizonte de posibilidades. Cabe preguntar, ¿realmente describimos nuestra cotidianidad para encontrarnos? ¿Nos tomamos el objeto de conocimiento en correlación con nuestro propio mundo?

El método fenomenológico es esa puerta que se abre para seguir haciendo reflexiones filosóficas, donde filosofar es un hacer y una tarea que implica volvernos hacia nuestra 
realidad concreta y ello determina un volver hacia nosotros mismos, describiendo su correlación con el mundo de la vida. Hacer, ver, vivir y describir para filosofar, es lo que he entendido de este método. Hacer vivencias, hacer ver, hacer descripciones de diferentes mundos, de mis mundos, el de mi vida universitaria, la intelectual, la vida social, la vida en familia, la del trabajo, la vida en pareja, la vida del viaje, la vida del encuentro, la vida de la lectura, la vida del diálogo, entre muchas otras.

Volviendo la mirada hacia nuestra cotidianidad, a la Lebenswelt, hacia los que copertenecen a nuestros mundos, lo que podemos y debemos ser y hacer como seres trascendentales. Podríamos iniciar otro tipo de pensamiento y reflexión filosófica Latinoamericana, formulándonos preguntas que impliquen poner entre paréntesis las teorías y citas de autores que memorizamos y repetimos sin sentido alguno para nuestra vida y nuestro mundo circundante y ver lo que aconteció en nuestro pasado, como lastre de un presente incierto y un futuro posible.

"El yo del último Husserl está determinado expresamente por la estructura de la temporalidad. Antes que el cogito, él es un yo puedo, un yo que desplazándose por el espacio móvil de los éxtasis temporales, puede contemplar su facticidad como lo que ha sido y lo que ha llegado a ser; que contempla esa facticidad como base para proyectarse hacia el horizonte de sus posibilidades.” (Herrera, 2009, p.305).

No obstante, las preguntas continúan abiertas y el mundo de la vida, infinito en sus posibilidades. Mientras la temporalidad se explaya en la facticidad de nuestro alrededor, cualquier posible fenómeno que allí veamos, permite abrir caminos distintos para quienes con Daniel Herrera, "queramos pensar en y sobre nuestra realidad colombiana." (2009, p.304) Hay varios telares por hacer, por constituir una reflexión propia, que nos sirve de suelo para hacer filosofía.

Este trabajo de investigación de Maestría, es una excusa para responder a tal hacer, ver, vivir y describir fenomenológicamente un mundo inmediato de mi vivencia, como lo es la escultórica de San Agustín-Huila, y que también es el camino abierto para continuar en el bosquejo de reflexiones filosóficas sobre Latinoamérica y Colombia, para aquellos que antojados, por ir a las cosas mismas asuman el reto de pensar sin teorías. 
Este hacer reflexión filosófica latinoamericana es el gusto por seguir pensando en el presente, como una actividad constante. Rememoro aquello que me sedujo de Foucault en aquellos días y ahora es lo mismo que me seduce de la fenomenología, el ponerme ante las cosas o alrededor de ellas, mirando la actualidad del mundo como quien mira un espejo, donde el primer implicado en la investigación es el propio sujeto que investiga, ese lugar de la reflexión en que todo termina siendo variantes de variantes, y posibilidades infinitas y abiertas para ser pensadas.

Es así como la vivencia del encuentro que he tenido en las cuatro visitas a San Agustín Huila, me hace detenerme frente y alrededor de su estatuaria, sus monumentos, sus montículos, sus tumbas, sus dólmenes, su gente, su olor, su comida, sus misterios, etc. Y con ello realizar un acto reflexivo y filosófico de ese lugar-otro. Aquel que percibido desde una vivencia fenomenológica, me genera indagaciones sobre el sentido de la muerte, la germinación de la vida, pero también el derrocamiento del sentido originario, el olvido ancestral, el silencio de las ídolos, presente en las huellas del llamado "Pueblo escultor".

Gracias al método fenomenológico es posible un acercamiento y vislumbrar variantes e invariantes, ideas y conceptos sobre la estatuaria de San Agustín-Huila, partiendo de una obra lítica y de las apropiaciones estéticas que fenomenológicamente se puede hacer de ella, a partir de la cual se comprende un sentido universal de toda la escultura agustiniana.

Con la mirada fenomenológica que se hace de una pieza arqueológica, es posible considerar las demás desde la reflexión filosófica, la cual permita acceder al ahí de un pueblo, a su mundo de la vida, y que como espectadores no nos percatamos de su estar, de su lugar originario. Esta aventura filosófica vivida, vista, descrita, hecha, ha sido el móvil de este trabajo de investigación, que busca ser un estilo filosófico. 


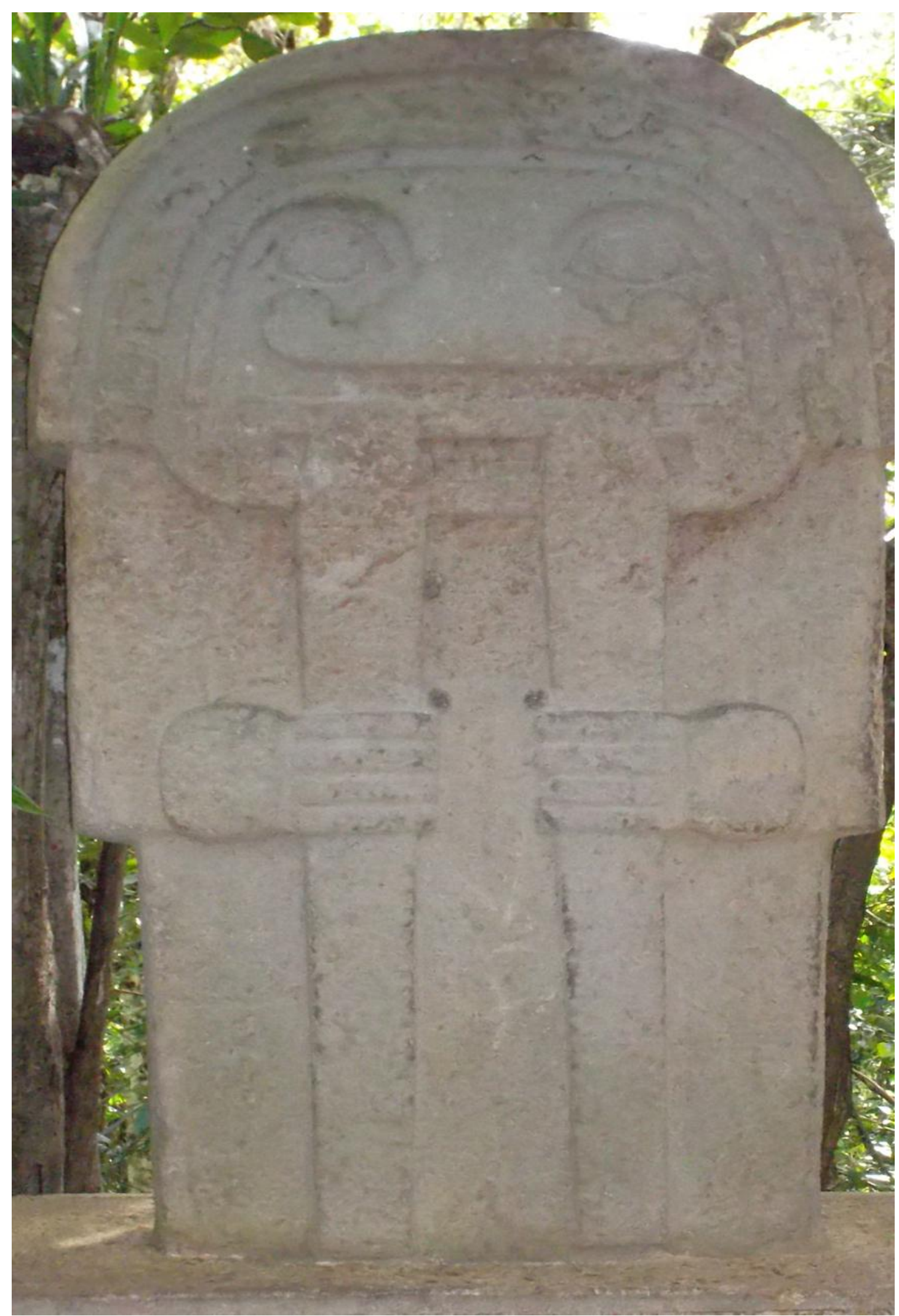




\section{CAPÍTULO II \\ 2. EL VER FENOMENOLÓGICO DE LA OBRA ESCULTÓRICA AGUSTINIANA}

Dentro de todos los fenómenos posibles que se pueden abordar fenomenológicamente, están los relacionados con el arte. Me voy al plano de la percepción donde el ver hace su aparición más próxima a mi mirada y cuya intencionalidad está invadida por la empatía. Ese ver de las obras de arte, solo puede darse en el marco de una vivencia radicalmente personal, cuyo ejemplar particular, posee cualidades singulares que me conducen a problemas filosóficos.

Hablar de arte en general constituye un universo de objetos que pertenecen someramente a la literatura, la pintura, la escultura, la danza, la música, recordando las musas y las artes griegas entre las que se cuenta también la cerámica y la arquitectura. Ellas nos seducen en algún momento de nuestra vida, a través de pequeñas expresiones; poemas, novelas, cuentos o crónicas; cuadros en oleo, acuarela, acrílico o tela; esculturas en marfil, bronce o piedra; cerámicas en barro, porcelana o arcilla; arquitectura sacra, urbana, profana o militar. De la danza quizá nos deleite la clásica, la flamenca, de salón, folclórica o contemporánea, y por supuesto una variedad asombrosa de piezas musicales; culta, tradicional o popular, de las más exquisitas a las más extrovertidas. Habría que mencionar también al teatro, el cine, la fotografía y las tendencias contemporáneas como el body art, los performance, las instalaciones, entre muchos otros, que tendrán obras tentadoras, posibles de ser modelos guía, o ejemplares singulares para un trabajo fenomenológico.

Pero llegan las preguntas: ¿Qué es arte? ¿Qué puede catalogarse como tal? ¿Podría afirmar que las esculturas de San agustin-Huila son obras de arte? ¿Verlas implica una experiencia estética?, y por tanto ¿son objetos artísticos dignos de una descripción fenomenológica? El simple hecho de mencionarlas como obras artísticas no las instaura en ese canon, habría que, como dice Gadamer, "recuperar la pregunta por la verdad del arte" (1993, p.121) la cual está relacionada con la vivencia, concepto propiamente fenomenológicohermenéutico. 
No se trata del gusto del arte, por el arte mismo, ello no me dice nada. Tomar un objeto cualquiera y decir ¡esto es arte ¡ me llevaría a un sensualismo vacío y a un "todo vale" que no responde a mis preguntas. Por el contrario, se trata de "aquello" que me permite tener una vivencia estética auténtica y originaria de la obra de arte. "Aquello" es la esencia, la cual posibilita la vivencia de un fenómeno particular que se me da como estético, y en ese dárseme, la relación entre la obra y yo, entre la obra y el espectador, se convierte en un encuentro estético y filosófico. De esta manera 1. La vivencia, 2. Lo estético, 3 Lo auténtico, y 4. Lo originario, formaría la imagen para abordar un ejemplar artístico de modo fenomenológico, desde una posible perspectiva.

\subsection{La vivencia estética auténtica y originaria}

"Parece incluso que la determinación misma de la obra de arte es que se convierta en vivencia estética, esto es, que arranque al que la vive del nexo de su vida por la fuerza de la obra del arte y que sin embargo vuelva a referirlo al todo de su existencia". (Gadamer, 1993, p.107)

Desde la perspectiva fenomenológica lo importante sigue siendo la experiencia del sujeto, y en este caso la experiencia propiamente estética sobre un singular, no importa cuán extensa sea la lista y cuántos ejemplares de lo pequeño podría tomar, lo fundamental es optar por uno de ellos como fenómeno particular de mi vivencia y con el que la puerta al trabajo arduo de la fenomenología, se abriría. Optar, es decidir y optar por lo particular es ya una decisión radical que implica un método distinto, donde se arroja al investigador a un enfocarse en lo diminuto de la vivencia humana en tanto experiencia de sí mismo, en este caso, una vivencia estética como experiencia fenomenológica de sí mismo y por tanto, una vivencia trascendental.

Se parte de un ejemplar singular, una escultura agustiniana. Ella en sí misma no declara ser una obra de arte, pero en mutua correlación con el espectador-reflexivo, se ofrece como tal. De esta manera, el modo de ver la obra se adecúa a la propia experiencia con la obra, el que ve, se deja conducir por ella, cae en sus tramas, juega entre lo visible y lo invisible de su esencia, y sigue los caminos que conduzcan a la obra misma. 
En este caso, el investigador es ese espectador-reflexivo, es quien se pone ante el mundo de la vida, y en él - además de vivir- capta para sí un objeto de sus experiencias cotidianas tomándolo como fenómeno de conocimiento, pero entre el uno y el otro se ejerce una correlación íntima que lleva a que él realice un autoconocimiento, tomándose también a sí mismo como un objeto en el lebenswelt.

El investigador es sujeto y objeto como los demás fenómenos, posee unas superficialidades en las cuales viaja para ver su propia constitución y la de los otros fenómenos, a través de variantes y conexiones de variantes.

Aquí la atmósfera que recubre el fenómeno es la del arte, no se trata de un objeto cualquiera sino de una obra artística y de un mundo estético. Por tanto, al abordar la obra desde el método fenomenológico, la realidad del investigador y del objeto artístico cambia y el mundo que los rodea es modificado esencialmente, haciendo posible la aprehensión eidética de un mundo que está dado en la experiencia. Así mismo, la vivencia ya no pertenece a un vivir vacuo y sin sentido, propio de una actitud natural, sino que es la posibilidad de tener experiencias trascendentales del yo en el mundo de la vida, una experiencia trascendental de forma estética.

En cuanto a mi obra, esta solo aparece en el instante en que existe una intencionalidad de mi conciencia que la percibe, no hay objeto de conciencia sin la conciencia del objeto. Por tanto, no hay obra de arte sin una conciencia de esa obra de arte, sin la conciencia de que es arte, que en otras palabras sería decir: el fenómeno artístico aparece a la conciencia como tal.

Pero la vivencia que se tiene con este tipo de fenómenos requiere ser descrita. Creemos que la academia artística es quien define qué es o no arte, quizá porque se piensa recurrentemente, que la autoridad para tratar este asunto es posesión de artistas y estetas. Pero este no es un ejercicio artístico es ante todo un quehacer fenomenológico. No importa si una obra o cualquier fenómeno pertenezcan a un saber específico, su singularidad permite ser abordada bajo el ver fenomenológico dado que su método lo atraviesa esencialmente, permitiendo pensarlo libre e infinitamente una y otra vez. 
Como cualquier objeto, aparece la obra, pero es artístico en tanto que intencionalmente tiene un contenido vivido para el sujeto a quien aparece. Gadamer, por ejemplo no desconoce que el concepto de vivencia está presente en la fenomenología de Husserl, en donde existe una unidad de la vivencia que es una referencia intencional. Gadamer hace la lectura de la quinta investigación, de "Investigaciones lógicas”, donde todos los actos de la conciencia al ser intencionales, constituyen una vivencia con un contenido psíquico, por así decirlo, que es la conciencia de haber vivido. Todas las percepciones aparentemente externas y desinteresadas son actos de la conciencia sobre el yo empírico que se refiere siempre a algo, en palabras de Gadamer, sería decir que "Sólo hay vivencias en cuanto que en ellas se vive y se menta algo.”(1993, p.91) En palabras de Husserl: “lo que vive el yo o la conciencia es justamente su vivencia." (2006, p.474).

Para el caso del arte, se entendería que la vivencia es la conciencia intencional sobre algo vivido, por tanto la vivencia de un objeto artístico, de "los Girasoles" de Van Gogh o de una escultura de San Agustín, es siempre intencional y por serlo es una vivencia personal, cuyo contenido es inagotable, las variables que se pueden hacer de ese objeto referido son infinitas, tanto como puedan hacerse desde los datos de la percepción, tanto como los de la imaginación que también son inolvidables ya que permanecen en el recuerdo, en el archivo, en la historia de quien o quienes han tenido la vivencia del fenómeno estético. Sin embargo, en esa pluralidad hay algo que se ofrece ${ }^{19}$, su esencia. La esencia siempre se da en "algo", hay un "algo" en todos los actos de conciencia, en todo contenido de la vivencia está en esencia un "algo" que es la totalidad del objeto, en este caso, de mi objeto artístico. Esencia que en muchos casos es incomprensible y difícil de mostrar.

El ver de un objeto cualquiera -desde la perspectiva fenomenológica- es intuitivo, intuir un objeto debe entenderse como lo que "nos es puesto delante de los ojos él mismo" (Husserl, 2006, p.703) intuir es un acto, es poner ante nosotros las cosas mismas, solo se intuye "algo", se intuye por ejemplo una obra de arte, un cuadro, una escultura, ese acto de intuir es ya ver lo que es la obra en sí misma. Ver lo que en sí mismo es ese cuadro, esa escultura.

\footnotetext{
${ }^{19}$ Término usado por Husserl, en Investigaciones lógicas. Capítulo 2. La conciencia como vivencia intencional. p. $491 \S 10$.
} 
Se plantea entonces la pregunta: ¿Cómo ver fenomenológicamente una obra de arte? Es aquí cuando la pregunta por la estética se hace relevante en miras de la aprehensión fenomenológica de un objeto artístico, no la estética en universal, sino en un particular desde el método fenomenológico. ¿Cómo ver la esencia de la obra de arte? o mejor ¿es posible ver su eidos?

Es como si la obra misma al aparecerse en mi intuición me obligara a verla como arte. Mi mirada se torna estética al verla, y la vivencia no es ya la vivencia cualquiera, sino una muy definida por su objeto, una vivencia estética. Pienso en "los Girasoles" de 1888 de Van Gogh que aprecié en The National Gallery y es imposible no recordarlos dentro de la sala 45 entre otros cuadros, con su paupérrimo marco de madera, con su amarillo pálido, quemado, triste y deshojándose, que me hablaba de una profunda melancolía que compartía al no estar en mi país con los míos.

Pero también pienso en el llamado "dios Sol” que en una de las esquinas del Bosque de las Estatuas, dentro del Parque Arqueológico de San Agustin-Huila, se encuentra hoy, con su mirada fija y sus ojos bien abiertos, su tocado de geométricas figuras formando una media luna, una nariz mirada desde el frente ancha y con sus fosas a lado y lado como usando una nariguera, dos mazos fuertemente agarrados con sus manos de cinco dedos que van desde sus fauces hasta el suelo, golpeando firmemente la tierra, y con una especie de águila o ave rapaz dibujada en la espalda a modo de un escudo o formando un corazón, pero sin que nadie lo reconozca como dios, sin que nadie conozca su rostro, su corazón y el sentido de su estar en un lugar tan nuestro y tan desconocido para nosotros los colombianos, que de la misma manera me produce gran melancolía.

Se aclara ahora una sentencia en mi mente: en fenomenología se trata de ver lo que la obra me deja ver. No le impongo mis convicciones, ni la pinto con los lamentos de mis preconceptos, la veo y ella coquetea conmigo en un juego entre dejarse ver y ocultarse, entre más me le acerco más me esquiva la mirada, poniéndome en la lejanía para bailar entre lo visible y lo invisible. Pero en cada vistazo y guiño la relación entre mi ver y la obra se hace más íntimo y personal, como diría Merleau-Ponty al hablar de la pintura, "Ver según ella o con ella" (1994, p.373). 
No simplemente se ve la pintura o la escultura, no solo se ve su color o textura o se aprecia su tamaño, sus rasgos, sus cualidades más visibles, sino que a la vez que la miro, quien parece estar mirándome es la propia obra, como si hubiera un poder externo que obligara mi mirada a dirigirse de cierto modo a ella y se reflejara en un espejo. No es un ver la representación de algo, la representación de unos girasoles o de un dios de la cultura uyumbe, ni tampoco es la mirada de un retrato o mímesis de la realidad, en este caso no es un ver biológico, donde el ojo recibe unos datos sensibles y a través de la luz, la percibo, organizando esos elementos como imagen en mi cerebro. Este ver es distinto, implica un correlacionarse con la obra, tanto así, que hay una participación de ella en mi mirada y por consiguiente, no hablaría de ver una obra como el espectador callejero, sino de un vernos con y en la obra. Nos vemos con la obra. Hay un vernos, ella y yo en el acto de percibirnos mutuamente.

Recuerdo ahora que "Los Girasoles" estaban dispuestos en una sala entre los que resaltaba quizá más por sus ostentosos cuadros y coberturas en vidrio, el Florero de Gauguin o el Retrato de Cezanne, pero especialmente esos Girasoles estaban dispuestos para quienes los miraba, no solo para los niños, adultos y ancianos que se amontonaban a su alrededor, sino particularmente para mí. Estaban también La Silla de Van Gogh, y Los cangrejos, pero eran aquellos tristes Girasoles quienes habían capturado mi atención, como si palpitaran fuera del cuadro y más acá de la sala saliera a una realidad propia, haciendo que los reconociera como vivientes igual que yo.

A la vez el "dios Sol” está dispuesto de tal manera que incluso el árbol que se encuentra a su costado haciéndole sombra y sirviéndole de techo, se inclina sobre él desde sus raíces hasta sus ramas, haciendo que al finalizar ese camino se vea la magnificencia de la obra para mis ojos. La textura de esta piedra resalta en mis dedos al ser tocada como la piel de un cuerpo frío e inerme da la sensación de muerte, pero también de grandeza, duda y silencio. Y aunque el circuito de aquel bosque fue diseñado con cierto camino para que el turista lo recorriera, es esa estatua y no las otras, la que me llama para ser vista, y a pesar de no ser el entorno originario, es ella la que me mueve a verla como obra artística incluso en las fotografías de la historia de su desplazamiento. 
El “dios sol” pertenece al estilo más clásico, o fase clásica del periodo escultural de San Agustín, según menciona José Pérez de Barradas, cuya descripción de lo más visible de la escultura diría: "Rodea la cabella una diadema de oro con un adorno geométrico, como los de los frescos de Chachan; los ojos elípticos tienen pupila; los brazos están doblados sobre el pecho; las manos agarran dos mazas o cetros.” (1943, p.143) Para los comerciantes que se ubican a la salida del Parque Arqueológico, es el "dios de la agricultura", según reseña la parte inferior de la estatuilla, y esos "palos" que lleva en sus manos, son los que se utilizaban para arar la tierra y cultivarla.

Esa estatua y no otra -que antaño se encontraba en la Mesita $\mathrm{C}$ del parque arqueológico ${ }^{20}$, llamada por Preuss: "Deidad con dos mazas en las manos" ${ }^{21}$, la cual fue desplazada a la plaza del pueblo de San agustin ${ }^{22}$ bajo el nombre de "un dios solar con mazas" y movida de allí, fue ubicada en un rincón del bosque artificialmente creado ${ }^{23}$. Pero que algunos lo nombran un "sacerdote con cetros" o "chamán con dos bastones" 24 -es la que en su poderío divino me somete a mirarla. El nombre que se le pueda dar a esta estatua podría ser otro, según las interpretaciones de las más sagradas a las más profanas, según las explicaciones científicas o mágicas, pero lo cierto es que ejerce un efecto de atracción tal que es inevitable no mirarla. Razón tiene Merleau-Ponty al afirmar que "uno no ve sino aquello que uno mira" (1994, p.369) y eso que se mira tiene una relevancia en la vivencia particular en el mundo y en el instante de ese mundo del cual hago parte.

En ambos casos, la obra es quien determina la vivencia estética, sin embargo, podría el turista cualquiera tener una vivencia con el objeto artístico, y su experiencia sería retratada en cámaras fotográficas, donde guardaría un recuerdo singular y personal que acumularía en su álbum de viajes sin ser una vivencia propiamente estética. Pero es la correlación con la obra la que implica una intimidad con ella de tal modo que al ser vista, intuitivamente,

\footnotetext{
${ }^{20}$ Según, Reichel-Dolmatoff, Gerardo, Pág. 99-Figura 67. Mesita C "statue with two staffs".

${ }^{21}$ Según, Preuss, K Theodor. Plancha No. 41-42. "Deidad con dos mazas en las manos".

${ }^{22}$ Según, Perez De Barradas, Jose Láminas: 9, 119, 120, 121, 122. "Estatua de un dios solar con mazas".

${ }^{23}$ Según, Gamboa Hinestrosa, Pág. 210. Figura 139-140. "sacerdote con cetros".

${ }^{24}$ Exposición 29 de Noviembre 2013 al 2 de Marzo 2014- "El silencio de los ídolos" Una evocación de la estatuaria agustiniana. Museo Nacional de Colombia. http://www.museonacional.gov.co/sitio/el_silencio_de_los_idolos/galeria.html
} 
sustrae al espectador a la realidad de la obra y a su vez, le otorga sentido a su propia realidad.

Como diría Gadamer al hablar de la pregunta por el arte, "Parece incluso que la determinación misma de la obra de arte es que se convierta en vivencia estética, esto es, que arranque al que la vive del nexo de su vida por la fuerza de la obra del arte y que sin embargo vuelva a referirlo al todo de su existencia". (1993, p.107) No es posible desligar el objeto artístico de la vivencia estética, hay una soberanía de la obra de hacer posible una experiencia peculiarmente diferente a todas las demás que solo es vivida por aquel que sabe mirar. Así, la determinación de la obra prevalece a las determinaciones del espectador, pero ambos se embarcan en la travesía de encontrar su propia realidad uno a través del otro. Con la obra y en la obra, camino su sentido para encontrar el mío y hacer posible que mi yo trasciende en este mundo de la vida.

Con y en la obra veo su mundo para ver el mío. Y ese ver con la obra es una forma de correlación, como quien camina con un amigo por el prado y conversa con él, ve con él, es un ver junto a, al lado de, y que aunque sean distintas las visiones se transita el mismo camino. Por su parte ese ver en la obra es como si viéramos a través de los ojos de ese Otro, ver en el lugar del Otro. Veo a través del "dios sol" alguien que me observa sin reconocerme, tomándome como otro, diferente y extraño. Con el "dios sol” recorro el parque y los demás sitios arqueológico y los veo como un lugar-otro.

La obra tiene una característica particular como si habláramos de una personalidad, con un carácter propio, "mundanidad del objeto estético" su "modo de ser" (Dufrenne, 1982, p.6) Aquel "dios sol" tiene una forma de ser que le es propia. Es un dios silencioso, no me habla, no me hace favores y al cual no adoro, las categorías no alcanzan a explicar ese silencio del que se es presa al presenciar una escultura sin título y sin autor, pareciera que las ideas y categorías fueran insuficientes para aprehenderlas en la grafía y donde finalmente la conciencia entra a ser consolada por la imaginación o la ficción, quien da elementos más cercanos al sentimiento y la pasión que a la lógica categorial. Desde una percepción sensible, el fenómeno es para nosotros como nosotros para él. Lo veo y me ve. También me veo en él. 
Ver implica habitar la obra en ese preciso instante, en un momento de actualidad. (Merleau-Ponty, p. 364) es un habitarse mutuo; "habitarnos" es un estar en. Estar dentro de. Estar en la obra y la obra en mí. La obra me habita. En ese momento único en que el ver hace ver. En el instante en que la obra se me da visible. No importa si es especialista en arte rupestre, o un arqueólogo capacitado en Alemania, o un simple campesino, o una expedicionaria como yo. El verdadero ver se da en la correlación entre la escultura y el espectador activo.

Quizá el ejercicio parezca extraño en estos términos, porque es como si la pintura o escultura cobraran vida en la vivencia estética, como si tuvieran un cuerpo, un aliento y una personalidad, como si se tratara de unos verdaderos girasoles a punto de morir, o como si las piedras respiraran, y como si las fotografías de antaño hablaran de la actualidad de esa piedra tallada por primitivos "notable por lo depurado del estilo y su severidad" (Duque, p.58), que se vuelven en este ejercicio fenomenológico seres independientes con los cuales se camina a su lado y se ve el mundo a través de sus ojos. Pero precisamente eso es lo que sucede a la hora de tener una vivencia estética vista fenomenológicamente; la obra de arte se vuelve actual y esencial, en el encuentro con el vidente la obra vive, palpita, fluye, mira, sonríe, se mueve, se suspende...

Con ello, el camino de la investigación fenomenológica para tratar una obra de arte se vuelve una travesía, una aventura o mejor, una expedición. La vivencia estética estaría en semejanza con el vaivén de una expedición arqueológica, una hazaña para encontrar tesoros escondidos o la búsqueda de animales exóticos en tierras desconocidas, en todos los casos se encontrarán abismos y peligros, pero la misma intensidad de quien realiza la aventura no alcanza a ser expresada para que los demás la comprendan si no lo han vivido.

Al hablar de George Simmel, Gadamer menciona la aventura, que "vuelve sensible la vida en su conjunto, en su extensión y en su fuerza. En esto estriba el encanto de la aventura. De algún modo le sustrae a uno a los condicionamientos y vinculaciones bajo los que discurre la vida habitual. Se aventura hacia lo incierto" (1993, p.106) Esa fuerza oculta que motiva tal vivencia es despertada por la obra en su singularidad, pero solo quien sabe mirarla puede ser presa de ese poder, corriendo el riesgo de estar caminando hacia algo incierto e 
incomprensible, pero que es consciente del "let it be" de la obra, ese dejarla ser...ella misma y dejar que uno sea con y en ella.

Esa es la aventura a la que me lanza el ver al "dios sol”, el cual sacándome de los lugares comunes y cotidianos, me lleva más allá de una caminata ecológica o arqueológica, y me captura de un modo inevitable, terminando enredada en su juego aventurero y coqueto, pero que luego de la sonrisa y las mejillas sonrojadas me retorna a lo habitual. En ese baile constante y fluido hay algo que permanece intacto: el querer volver hacia un origen. Ir hacia el origen de quien me ha hechizado. Ir al origen de la obra, ir al origen del "dios sol", ir a su esencia.

Michel Henry, al hablar de la pintura lo llama el "plano originario" de la obra donde éste existe "como una realidad autónoma, virgen, como un ser vivo: [que] tiene una respiración..." (2008, p. 75) y como realidad viviente la obra artística tiene "alma”, un espíritu que la determina y la constituye como sí misma.

Así, el trabajo fenomenológico de manera más precisa es hacer "la indagación retrospectiva por el sentido más originario" (Husserl, 1954, p.366) de esta obra, ya que es ella la que me incita a preguntarme y preguntarle por su tradición, por su génesis, por cómo llegó a ser lo que es, y a pesar del tiempo está ahí presente ante mí y ante otros ojos permaneciendo en "viviente elaboración” como diría Husserl. Ello es lo que me mueve aún más a cuestionarme por "los comienzos originarios" (Ibíd.p.366) del "dios sol”, cuya indagación por la unidad interior que da vida a aquella escultura de piedra, remite al sentido por "el mundo cultural en su conjunto" (Ibíd.) el cual la hace posible viviente o sobreviviente en la actualidad.

Esa tradición de la obra donde se narra la historia de su vida, cobra relevancia en la descripción fenomenológica, pero ahondando en ella desde su esencia. Solo así, es posible ver ese sentido originario que guarda. Para el ejemplar Kandisnsky que toma Henry, el plano original está "en la composición simple o melódica,... y en la composición compleja o sinfónica" (2008, p.119) como si se tratara de vibraciones musicales que están presentes en el punto, la línea, el color, las formas, y que en el fondo son todas ellas elementos de una "composición puramente abstracta" (Ibíd., p.121). Pero luego de la descripción de las partes vistas desde lo abstracto, se evidencia como visible que la obra de Kandisnsky en 
esencia es "una vida amplificada de la experiencia estética" (Ibíd., p.10) del mundo, la vida y la cultura rusa.

No obstante, esa es la mirada de Henry sobre un modelo particular que es la pintura abstracta de Kandisnsky, seguirlo a cabalidad sería situarme en lugares comunes, ineficiente para tratar una obra escultórica precolombina. Husserl, revoluciona el quehacer filosófico con una simple y llana frase: Sin teorías, eso suena al "Sapere Aude" kantiano, una incitación, un reto que nos provoca para hacer filosofía del mundo, de la propia experiencia, de los Otros, de lo Otro y que más allá demuestra que sí es posible un vivir filosófico de forma distinta y una investigación fenomenológica del mundo latinoamericano.

Por ello hay que recordar aquí que el Ver en fenomenología es un acto que constituye simultáneamente el acto de intuir y captar una esencia en niveles de complejidad, por lo cual es necesario según Husserl, aprender a ver. Este aprendizaje implica un ejercitarse en ver sin teorías pre-establecidas. Ver la obra escultórica a través de la obra misma, verla de acuerdo a la relación intrínseca de sus determinaciones propias; su espacialidad, el lugar que habita, sus materiales constitutivos, sus formas, su textura, su color, sus líneas, sus hendiduras, sus cambios, su desplazamiento, en fin, sus variantes. Pero también se trata de ver todo ello según una correlación con quien la ve, la interroga y comparte ese entorno que la subyace.

Si el Ver husserliano pretende intuir las vivencias en cuanto tales, el modo ordinario de vivirlas debe ser modificado. Las intuiciones que podría tener de una obra como "el dios sol" me llegarían entonces, necesariamente, como sensaciones vividas en sí mismas originarias. Toda intuición en esencia es originaria dado que fue algo vivido.

Al ver el "dios sol” la primera intuición que llegó a mí es un profundo silencio, la estatua no dice nada. Solo silencio e incógnitas. Una vivencia originaria de este tipo no podría ser considerada como simple dato defectuoso de mi percepción sensible, del cual resultaría una copia o una réplica que me haría tener ideas erradas de la obra; no hay ideas erradas, hay intuiciones del fenómeno y a través de ellas se llega paulatinamente a la esencia. 
Cada intuición que tengo de la obra, cada mirada, cada acercamiento, puede considerarse originaria porque hace parte de la obra en sí misma. Si la primera intuición fue el silencio, en la siguiente, ese mismo silencio me suscitó respeto por aquello que estaba viendo. El ímpetu de algún soberado y adorado dios que tenía algún poder divino. Como si se tratara de algo prominentemente importante para una comunidad. Pero ese respeto se sumerge en el olvido, en la pérdida de los colores de su piedra desteñida por el aire, en el robo de su diadema en oro e incrustaciones de las que solo existe el vacío. Un dios no reconocido, no respetado como sagrado, un dios-solar sin un sol que lo ampare, sin una ofrenda, sin peticiones, sin altar, y que para nosotros no significa más que una escultura primitiva precolombina de gran tamaño. Una simple estatua, al que no le pedimos favores, ni le rogamos su perdón. Quizá ni siquiera sea un dios, quizá no interese sus cualidades, sencillamente porque no las entenderíamos.

Sin embargo, Husserl me dice que "Las intuiciones que únicamente pudieran ser vivificadas por impresiones remotas e imprecisas, inauténticas -y en el supuesto de nuevas se tratará realmente de unas intuiciones- no podrían satisfacernos. Nosotros queremos volver a las cosas mismas". Las intuiciones: silencio, respeto y olvido, no me satisfacen como esencia del "dios sol" son imprecisas e inauténticas. Husserl, nos indica que puede presentarse dos posibles maneras de darse esa intuición, una totalmente adecuada, auténtica y originariamente, y otra de manera inadecuada.

Y aunque nos podríamos ilusionar con la primera opción, él aclara que esa es en sí misma una posibilidad imperfecta, ya que "es inherente a la peculiar índole de ciertas categorías esenciales el que las esencias correspondientes solo puedan darse «por un lado», o por varios lados sucesivamente, pero nunca «por todos lados» (Husserl, 1994, p.20).

En todo caso, la esencia no se da visible completamente en su totalidad. Todo esfuerzo por ver, es siempre un ver en perspectiva. Puedo ver el "dios sol" desde la perspectiva del silencio o desde el respeto. Pero si pensábamos en algún instante que con solo ver una vez la escultura del "dios sol", se haría visible en su totalidad intuyendo de inmediato el esplendor de su esencia, nos hemos equivocado.

Quizá podrían existir algunas esencias que de inmediato se den totalmente visibles en la intuición, pero aunque creamos que se nos da clara y distintamente, deben ser tomadas con 
sospecha, ya que todo concepto, idea o mención, que me pueda hacer de ella, caerían inevitablemente en la forma inadecuada de que se dan por principio en meros «escorzos» visibles por un solo lado (Husserl, 1994, p.21).

No es posible conformarme tampoco con las intuiciones de otros que manifiestan por ejemplo, que la estatua del "dios sol" es similar a la del dios chavin, "figura central de la puerta monolítica de Tiahuanaco ${ }^{25}$, o seguramente igual a las encontradas en la cerámica procedente de Pachacamac" (Pérez de Barradas, 1943, p.143) o confiarme de la definición de que toda obra escultórica agustiniana es la representación de una "cultura espiritual" precolombina.

Tampoco me basta con el "dios sol" visto en el bosque de las estatuas, con su base de cemento, pegada a un rectángulo que contrasta grotescamente con la textura particular de la piedra. No me bastan las fotografías tomadas desde distintos ángulos, ni con los efectos de la luz del medio día que crean visiones en aquella piedra, que cada vez la dejan ver más blanca y erosionada por el tiempo, el sol y la lluvia.

Por eso es preciso caminar hacia la profundidad y tomar para sí una esencia, desde la cual en perspectiva pueda ser visible para mí. Ese querer volver a las cosas mismas es el querer retroceder al origen, ir al origen de la obra, que en definitiva es ir a su esencia. Hacer una excavación del origen de la escultura, hacer una expedición originaria del "dios-sol” es ir a su esencia. Por tal razón la intuición auténtica no sería la suma de todas las intuiciones, sino la intuición originaria del objeto, y en este caso la intuición originaria de la obra para tener una auténtica vivencia estética.

La intuición será auténtica cuando sea clara y evidente, con tal obviedad que no requiere ser explicada sino que ella en sí misma se muestra como real. Y esa evidencia "no quiere decir otra cosa que la aprehensión de un ente con la conciencia de sí, como original darse él mismo ahí. La realización exitosa de un proyecto es evidencia para el sujeto activo, en ella lo realizado se da ahí originalmente como él mismo.” (Husserl, 1954, p. 367) Esa intuición auténtica que lleva a la vivencia auténtica de la obra, es la que aparecerá como esencia de la escultura, y a pesar que las otras intuiciones aparezcan como esenciales, son

\footnotetext{
${ }^{25}$ Tuahanaco y pachacamac fueron ciudades-templo, importantes dentro del imperio Inca.
} 
inauténticas para quien la vive. Allí radicaría lo auténtico de la vivencia. Es auténtica porque sus contenidos son presentativos. (2006, p. 655) se me presentan y están ahí para mí.

En esa intuición auténtica se $d a$ la esencia. O lo que es lo mismo, la esencia se $d a$ en la intuición y allí es donde se hace visible. Hablar de lo visible es hablar de lo visible de la esencia en la intuición. La escultura se me presenta visible cuando tengo la intuición de su esencia. Podría decirse, que todas las intuiciones, adecuadas e inadecuadas, hacen parte del mismo proceso evolutivo de la intuición o un proceder genético de la intuición que mira hacia el origen, aquel origen que se presenta en la esencia que se intuye auténticamente.

Lo originario y lo auténtico van entrelazados de tal manera que permiten tener la vivencia de una obra estética. Si la vivencia estética es determinada por la obra del "dios sol”, las auténticas intuiciones de esa vivencia me permiten acceder a su origen. Siguiendo a Gadamer para la estética esto tiene como consecuencia que el llamado arte vivencial aparezca como el arte auténtico.

El verdadero arte es aquel que es vivencial. La vivencia escultórica o la vivencia monumental de San Agustín, no podría constituirse de igual forma para todos, podrían ser consideradas por muchos unas simples experiencias con piedras primitivas, ruinas, reliquias o hallazgos arqueológicos, manifestaciones mágicas, demoniacas, paranormales, sagradas, políticas, psicológicas, etc. Pero en lugar de esto, accedemos con la mirada fenomenológica a un ejemplar, vivimos la obra, de tal modo que la vivencia estética o la experiencia del arte se vuelven auténticas y originarias, especialmente para mí, para aquel sujeto activo, para el investigador que la está viendo.

Así pues, luego de tener la esencia y de tener con ella la vivencia estética originaria y auténtica, se requiere hacer una ideación de la descripción de la obra y presenciar el origen mismo. Si se habla de una contemplación de las esencias, en cuanto al método fenomenológico se trata, entonces hablaríamos de una contemplación de la experiencia de la obra estética, de la vivencia. Por tanto, "la experiencia estética debe orientarse prioritariamente hacia la contemplación ejercida por el espectador hacia el objeto estético" (1982, p.19) allí es donde comenzamos y terminamos: en la contemplación originaria y auténtica de un objeto artístico. 
Es claro, que el objeto artístico se co-determina con el método fenomenológico, bien podría tratarse el mismo objeto desde otro método pero en esta ocasión es a través de la fenomenología que la obra aparece en un escenario distinto para ser percibida eidéticamente. Esta pretensión de la vivencia estética, estaría en el nivel de la vivencia filosófica, esta y aquella guardarían para sí, las mismas exigencias de método con objetos de conciencia diversos.

De allí, que en el epígrafe del libro La fenomenología de la experiencia estética, Dufrenne habla con seguridad al decir que "La estética, al estudiar una experiencia que es originaria, reconduce el pensamiento - quizás la misma conciencia- al origen. Ahí reside su principal aporte a la filosofía" (1982, p.7) pero a la hora de ver la fenomenología como un retorno a lo originario y por tanto ver sus objetos de estudio a través del método descriptivo, aclaran un pensamiento filosófico. La primera sería lo que se conoce como una estética fenomenológica $^{26}$ y la otra, una fenomenología-descriptiva, como la que presenta en este trabajo.

En el acercamiento fenomenológico de la obra de arte, el investigador tiene la posibilidad de tener una auténtica experiencia, que no lo deja inalterado, sino que al ver la esencia de la obra siente como si ella tuviera un modo de ser propio, lo cual permite percibirla como un Otro real, Otro que se hace visible, y que en el fondo desea comprender. “... El comprender forma parte del encuentro con la obra de arte, de manera que esta pertenencia sólo podrá ser iluminada partiendo del modo de ser de la obra de arte.” (1993, p.142) La obra de arte tiene una determinada forma de ser, una personalidad que se muestra con un cuerpo, un carácter que se hace presencia.

No obstante, antes de tratar de comprender la obra o llegar a interpretarla, como suele hacerse de improviso con todos los objetos artísticos, es necesario hacer visible la esencia, verla para sentirla, vivirla, vivir su presencia, y todo ello no es más que un estar en contacto con la obra misma, palparla para una verdadera presencia, como Otro y como una

\footnotetext{
${ }^{26}$ Entre otros pensadores que se encuentran en esta línea de una estética fenomenológica están: Nicolai Hartman, Dino Formaggio, y los ya mencionados en el primer capítulo: Mikel Dufrenne, Moritz Geiger, Roman Ingarden.
} 
experiencia estética auténtica y originaria. Y por supuesto, la forma para estar en ella se da mediante una descripción fenomenología de esa experiencia.

Así se entiende que, ver una obra de arte como la del "dios sol" es una vivencia subjetiva del objeto. La intuición de esencias de la obra artística pertenecería al plano de la subjetividad pura. Aquella donde cobra sentido la obra misma y el sujeto mismo que en correlación con ella se manifiesta. Por tanto la vivencia entra también en este reino, donde la vivencia estética auténtica entra a las esferas de la subjetividad trascendental y se convierte en un problema radicalmente fenomenológico.

Por supuesto, Husserl no hace una fenomenología del arte, tampoco una teoría estética, no hay una sistematización de la estética en el pensamiento de Husserl. (Chávez Báez, 2005, p.4) pero a partir de sus enunciados, postulados y pautas de método es posible ver fenomenológicamente un objeto de mi vivencia, una obra de arte, que en este caso es una obra escultórica agustiniana, y desde allí, contemplar los planteamientos que sirven de guía para ver y proceder metodológicamente, y lograr un trabajo personal e inédito, en cuanto al ejercicio fenomenológico-descriptivo del particular.

Este lugar aún no explorado por la filosofía latinoamericana abre el camino, que con la escultura traza una línea de lo que podría llamarse una fenomenología escultórica o una fenomenología agustiniana. Los postulados de todos los autores citados son puestos en

paréntesis para evitar a toda costa que sean la base y directriz fundamental de la investigación, y ya que el método fenomenológico posee cierta flexibilidad, la decisión radical de pensar "sin teorías" será la máxima que guíe la propia vivencia sobre un ejemplar, el cual se mostrará por sí mismo.

\subsection{Lo visible y lo invisible en la escultura agustiniana.}

Una descripción fenomenológica de un cuadro como Los Girasoles no es el mismo que ha de hacerse con el de una escultura, y tampoco igual al de cualquier escultura clásica o la primitiva agustiniana. En mi mente sigue más vivo aquel "dios sol” desconocido que no paro de mirar en mi recuerdo, que se muestra en las fotografías a color de mi cámara y 
aquellas otras que a blanco y negro capturaron arqueólogos y dibujaron cronistas de antaño.

La descripción de aquel "dios sol", debe continuarse en relación con su lugar de origen, con su entorno, para así ver lo más visible de la escultura agustiniana como general y vislumbrar lo invisible que se me da y se presenta en los recuerdos de cada viaje, para así tener la vivencia estética auténtica y originaria de la obra e intuirla esencialmente. Sin embargo, para llegar a ello, veo la obra como un individual, simple, sencillo, y se me da visible en tanto cosa individual, es claro que la cosa es visible en cuanto a lo individual se refiere (Husserl, 1949, p.22), ya sea porque ponemos como ejemplares particulares datos de la percepción, del recuerdo, y /o en datos de la fantasía (Ibíd., p.23). En cualquiera de estos casos, la obra se da visible en la intuición empírica, pero ello no quiere decir aún, que al ser visible en sus cualidades más particulares, pueda aprehenderla esencialmente.

El paso de una intuición a otra, de la individual a la esencial, no puede darse por separado, sino que la una implica a la otra necesariamente. "No es posible ninguna intuición esencial sin la libre posibilidad de volver la mirada a algo individual que le corresponda y de desarrollar la conciencia de un ejemplar -como tampoco, a la inversa, es posible ninguna intuición individual sin la libre posibilidad de llevar a cabo una ideación y de dirigir la mirada en ella a las correspondientes esencias que se ejemplifican en lo individualmente visible” (Ibíd.,p.22) Así que, si la veo en la intuición empírica ahí ya se hace visible la esencia, y a la inversa, si la intuyo eidéticamente, ya se me da visible en lo concreto, por lo cual me permito describir aquí lo más visible de las escultórica agustiniana, verla en sus matices para ver lo invisible, que sería su esencia.

Me dirijo con la mirada del recuerdo y voy hacia uno de esos lugares no explorados. Visito el Huila. En un viaje de 11 horas desde Bogotá, tengo mi primer encuentro con San Agustín. Con expectativa, pienso en las famosas "piedras" pre-colombinas, un lugar arqueológico importante según los expertos. Con una ligera maleta de campaña, el único par de tenis, ropa cómoda, una cámara, una libreta y un lapicero, me dispongo a conocer el lugar mencionado.

El tema de las antigüedades siempre me ha llamado la atención. Recuerdo las visitas al Museo del Oro, el Museo Nacional, los viejos teatros de Bogotá, la arquitectura colonial en 
cada pueblo o ciudad de mi país, el Museo de Armenia con aquellas figuras orfebres de una cultura fundadora como los Quimbayas, todo ello con el objetivo de tener una mirada de lo más próximo, de lo propio, conocer lo nuestro y responder a la pregunta filosófica: ¿qué soy? ¿Quiénes somos? ¿Cómo somos? y realizar una experiencia filosófica latinoamericana desde lo concreto.

Pienso en San Agustín, un lugar bordeado de bellos paisajes y un misterio escultórico por descubrir, por ello es distinto a todos los demás lugares. Guarda un enigma. Tiene un "algo" especial. Recuerdo recorrer unos 540 Kilómetros para ir hasta San Agustín desde Bogotá, despojándome de sacos y cobijas, también de los comentarios y "convicciones previas" que me acompañaron durante el viaje.

Me dispongo a ver. Ver la llamada "capital arqueológica de Colombia", postulada así entre muchas otras zonas importantes de América como Machu Pichu (1450 d.c), Tenochtitlan (1325 d.c), Chichénitzá (525 d.c), pero siendo más antigua que todas estas, según datos de carbono 14, que demuestran que algunas estatuas en madera y sarcófagos fueron elaborados en el año 150 a 300, a. C (según Pérez de Barradas), en el siglo VI a.C (según Luis Duque Gómez), en el año 1000 a. C (según Barney Cabrera) o en el año 1500 a. C (según Reichel Dolmatoff) y sin embargo, las excavaciones más recientes llevan a pensar que sitios como el Alto del Lavapatas tienen evidencias de un "fogón de piedras" de 3.300 años a. $C^{27}$ (Ver cuadro 1, 2 y 3).

Esta cultura agustiniana, según los expertos, tuvo un espacio-tiempo importante "Duque Gómez, Cubillos y Reichel Dolmatof muestran un desarrollo temporal sumamente extenso de 4.710 años, comprendidos entre el 3.300 antes de nuestra era y 1.410 años después, fecha límite que hacen de la cultura agustiniana la cultura de más extenso desarrollo en toda la América precolombina" (Gamboa Hinestrosa, 2007, p.76) tiempo en el que se elaboraron las estatuas en piedra, se desarrolló la orfebrería, la arquitectura de dólmenes y tumbas monumentales.

Pero aunque todo ello nos deslumbre en cuanto a fechas se refiere, es clara la falta de precisión en la cronología, así como las distintas hipótesis del sentido de hacer estas obras,

\footnotetext{
${ }^{27}$ Esto según un cuadro cronológico publicado en 1980 por Duque Gómez y Cubillos.
} 
y que finalmente, lleva a pensar que la estatuaria agustiniana sigue siendo un enigma, que no se aclara más que lo que se ve en las fotografías de su historia y no deja ver más de lo que los ojos ven en la actualidad.

De ese mundo imaginado que posiblemente existió muchos años antes y cuya población no tuvo contacto con la colonización española, se extinguió, desapareció, se desvaneció o simplemente nunca vivió allí, solo quedan como testigos de su existencia las obras monumentales de autores anónimos, sin títulos y sin memoria. La estatuaria es el único testimonio de la existencia de un pueblo que las elaboró, que tenía, seguramente, un sentido del mundo de la vida, del mundo de la muerte, del mundo social y político, del mundo de lo sagrado.

De allí, que se relacione este lugar con el pasado de un pueblo desaparecido, que antaño tenía por oficio o tarea esculpir, tallar y pintar las «piedras», como quien escribe en la actualidad sobre el papel donde consigna todo lo que siente y piensa. La «piedra» es aquí el lienzo o el papel, el lugar de la escritura, el lugar donde se expone toda una cosmovisión o quizá un modo de pensamiento propio, que no hemos vislumbrado.

Todo esto, son especulaciones inexactas, son ideas puestas por nosotros que ahora somos testigos de algo desconocido. Son solo «escorzo» de la esencia, matices, eso es que por ahora se ha dado como lo visible de la escultura, y lo que es visible siempre se da como una parte de la cosa, no son visibles las cosas mismas por sí mismas, sino que las percibimos solo a través de meros matices, (Husserl, 1994, p.96) o escorzos imperfectos, y esto no por culpa de la ceguera de quienes las apreciamos, sino por "nuestra humana constitución” y tampoco por una “caprichosa obstinación” de las cosas, sino según Husserl, porque hay una necesidad esencial, según la cual, las cosas se dan visibles, por ende perceptibles, únicamente para un Yo, sólo se dan para mí, que a la vez me doy a la cosa, me doy a la obra.

Ambos nos damos mutuamente. Pero esa forma de darse de la obra, no se da en un solo sentido sino en distintos "modos de aparecer" y ese modo surge gracias a una orientación que es nueva cada vez que se ve un lado o se ve el otro de la cosa. Y la escultórica agustiniana se me ha aparecido en otros modos. 
Veo el entorno, me pierdo entre los cafetales en la alta montaña, de tinto suave claro y dulce que se bebe en la mañana, en la tarde o después del almuerzo, en la plaza o en la cafetería, veo los cultivos de fríjoles como parte del menú en los restaurantes, cultivos de maíz, con el que elaboran panecillos en forma de anillos. También están los cañaduzales que varían el paisaje, cortados en los trapiches y materia prima de panelas y guarapos de cocción a vapor. Veo los árboles de quinua y los platanales, de cuya hoja sacan la fibra para tejer mochilas, sombreros, monederos y artesanías en general.

La gran variedad de esta tierra fértil me sorprende a sus alrededores, las tonalidades del verde por donde se mire, entre abismos y montañas que le hacen reverencia al estrecho del Magdalena y a su naciente agua fría y cristalina, pero donde también habitan estas "piedras", unas tras otras, escondidas quizá en muchas de sus serpenteantes árboles, podría afirmarse que todo ello es lo visible entre lo visible que da a la vista un magnífico banquete. (Ver foto 1).

Veo el pueblo agustiniano y en vez de una comunidad indígena en la actualidad que pudiera hablarnos de sus antepasados directos que esculpieron esas piedras, veo un pueblo de arquitectura colonial, de balcones floreados, puertas verdes y paredes blancas, que contrastan con el techo en tejas de barro y arcilla, algunas desgastadas por el tiempo. Una sola calle larga horizontal que cruza el municipio de $29.687^{28}$ habitantes, desde la montaña a la plaza de mercado. Las montañas de los andes de árboles frondosos de la cordillera central y oriental completan el paisaje y son el horizonte de la tranquilidad y el encuentro consigo mismo.

Pero las estatuas no parecen significar nada más que un turismo paupérrimo para estos habitantes, no hay apropiación de una cultura milenaria, tampoco orgullo, ni mucho menos apego por esas "piedras" que los turistas van a ver como algo exótico. El pueblo solo tiene unas pequeñas agencias de turismo que ofrecen recorridos por las zonas arqueológicas, en jeep o a caballo, tiene alguna otra réplica en la estación de policía y unas cuatro estatuas originales, que están en las esquinas del parque principal, una de las cuales tiene la figura de un hombre acuclillado, con rostro humano y en cuya posición toma con los brazos sus

\footnotetext{
${ }^{28}$ Según registro del DANE 2005
} 
rodillas y deja al descubierto los pies. Ahí está y permanece para ser visto como una obra escultórica de nuestra historia. Para decir, aquí estuvimos y aquí estamos.

Sigo con la disposición de ver unas "piedras" arqueológicas en el llamado "Pueblo escultor", título otorgado en 1.892 por el General colombiano Carlos Cuervo Márquez ${ }^{29}$, cuyo entorno paisajístico oculta sus monumentos en el Parque Arqueológico, el Alto de las piedras, Alto de los Ídolos, el Tablón, el Purutal, la Chaquira, Obando, San José de Isnos, (Ver mapa 1) entre 50 lugares arqueológicos y otros más, perdidos en las montañas aún no explorados e ignorados. En medio de las montañas, en el bosque, en los altos, en las mesitas y en los montículos, se hallan las esculturas en piedra. Ahí yacen las estatuas petrificadas en silencio, sin ser vistas por la mayoría de colombianos, pero visitadas cada año por 100.000 turistas extranjeros aproximadamente.

Al estar frente a una escultura de San Agustín, nos vemos como simples espectadores del turismo cultural. Sin nada nuevo qué decir, nos volvemos repetidores de mitos e historias fantásticas contadas por los guías, copiadas en análisis arqueológicos e incluso sociológicos y antropológicos de la academia que las registran en sus publicaciones. Toda la estatuaria se presenta como huellas borrosas de un pasado desconocido y un presente reconstruido. El tiempo ha dañado las esculturas, les ha quitado sus colores, entre los que aún se perciben, negros, amarillos de la semilla del árbol copé y ese hermosos rojo del achote, con que según dicen, las decoraban (Pérez de Barradas, 1943, p.145).

Muchas preguntan nos asaltan, entre ellas ¿cómo las hicieron? ¿Por qué las elaboraron? ¿Quiénes eran? Solamente queda hacer especulaciones sobre porqué llegaron o porqué se fueron, ¿quiénes conformaban ese pueblo?

Algunas teorías de tipo difusionista como las de Reichel Dolmatoff (1978), dirían que fueron oleadas de diferentes pueblos que llegaron a estas tierras, invadiéndolas y creando los diferentes periodos del estilo escultórico y funerario de la zona, dividiendo esos tres periodos, que corresponderían a tres tipos distintos de culturas: periodo formativo tardío, complejo de Isnos y periodo protohistórico. Esta hipótesis en parte ya había sido

\footnotetext{
${ }^{29}$ San agustin se conoce con ese nombre desde 1892: "But Pueblo Escultor--the name coined in 1892 by colombian investigator Carlos Cuervo Márquez--is a much better title for the ancient stone-sculptors" según: http://www.sanagustinstatues.org/bienvenidaen.html
} 
mencionada por Pérez de Barradas en 1943, el cual hablaba de cuatro fases: arcaica, inicial, clásica y protagonal, donde se asocia la escultura con el arte de la cultura chavin, tupi-guaranúies y de Tiahuanaco, y que luego de haberse asentado en esas zonas se desplazaron hacia Tierradentro, asentándose en el valle de Las Papas a causa del desalojo por los arawac del Cauca, relacionando finalmente esto con la cerámica de Tunkahuan en Ecuador (Cf, cuadro 1).

Por otro lado el antropólogo Carlos Sánchez en 2001, pensará que se trata de una cultura y población propiamente colombiana con asentamiento en esa región, que evolucionó y cambió históricamente. Lo cual se evidencia en "patrones de asentamientos de los diversos periodos socio-culturales" según el análisis del suelo y la coincidencia con los periodos de desarrollo, donde la escultura "a falta de excedentes en la producción de sus huertas, rendían tributo a los caciques a través de monumentos funerarios. Años anteriores el antropólogo Duque Gómez (1963) crea otros periodos de desarrollo cultural agustiniano, afirmando que existía un solo pueblo con una "continuidad de la cultura en diversos periodos evolutivos", dividiéndolos en formativo regional, clásico regional y tardío. (Ver cuadro 2) Pero que en definitiva sigue siendo un "pueblo misterioso, cuyo nombre quedará quizás para siempre ignorado" como escribió en algún momento el General Carlos Cuervo Márquez.

Y aunque las teorías se contrapongan unas de otras, y quizá continúen siendo estudio de antropólogos y arqueólogos, lo único que tengo ante mis ojos como visible y con certeza, es que hay unas esculturas que desenterradas desde 1803 están allí, son factum, son obras y no dicen nada. Solo un gran silencio las encierra. Para muchos se trata de ir a las estatuas mismas, por lo que intentan acercarse desde la historia, desde el arte, incluso desde la iconografía, vistas como "sistema religioso con aplicación a la vida social" como escribió Agustín Codazzi.

No podría encontrar el origen y el final de tal pueblo, eso quedaría en la invisibilidad de lo invisible en la historia incompleta de los primitivos, pero sí quizá lo invisible de las obras, aquello que no se muestra y es el origen de un sentido posible, que de voz al silencio al que todos nos enfrentamos al ver tales esculturas. Silencio que en un inicio, estaba lleno de estupor y miedo por su vacuidad pero cada vez se llena de contenidos. 


\subsection{El derrocamiento del sentido originario de la escultura agustiniana.}

Llego a ese "Lugar Otro" lejos de mis lugares comunes, percibo las cosas de la vida y de la muerte esculpidas en monumentos líticos. Mis ojos se abren al ver increíbles e inmensas estatuas zoomórficas: monos copulando con humanas, ranas en tercera dimensión, un búho mordiendo una serpiente, una máscara triangular semi-enterrada que sonríe como haciendo una mueca con colmillos de jaguar (Ver foto 2) Luego, hundo mi vista en los sarcófagos profundos, en tumbas, dólmenes y lozas fúnebres, donde seguramente enterraron a personajes importantes cuya función en vida debía ser prolongada en otro mundo o en un submundo, cosa que parece representar los guardianes de los templetes, que custodian la entrada a estos centros funerarios, unos "centinelas de la eternidad" como les llamaba Agustín Codazzi. En especial recuerdo aquel montículo oriental de la Mesita A, (Ver foto3) que con un tamaño de $2 \mathrm{~m}$ con 56 de alto, $110 \mathrm{~cm}$ de ancho y 80 de grueso (Dellenback, 2012, p.207) el cual muestra con magnificencia la tumba, al parecer de algún poderoso.

Pero con sorpresa luego de una búsqueda en textos históricos y archivos fotográficos, encontramos en la investigación que esa famosa escultura monumental, ícono de la estatuaria agustiniana, fue puesta allí, es un montaje turístico, no es su lugar de origen. (Ver Imagen 1-2) Así como el "dios-sol” y muchas otras han sido movidas, puestas, sobrepuestas y adecuadas para inventar un posible sentido de la estatuaria que se acomode a las interpretaciones ya dichas por arqueólogos y no adecuando la interpretación a las obras mismas. (Ver Foto 4 e Imagen 3, 4 y 5) No se ha respetado la obra en sí misma, ni su suelo, ni el lugar de su origen, todo ello ha sido modificado, ha sido derrumbada su autenticidad.

Continúo viendo el mundo circundante que se me muestra, y veo que aquel pueblo escultor sigue velado, no sabemos leer sus códigos, ni sus signos, no tenemos una piedra roseta que nos explique los significados de los tocados, manos, dientes felinos, máscaras, "dobles yo", ranas, micos, peces, mujeres y hombres, porque desconocemos la historia de los saberes y del sentido simbólico que encerraban dentro de un posible sistema de conocimiento del mundo de la vida y de la muerte en cierto tiempo y espacio. 
Sin embargo, sabemos con Husserl que "las expresiones sensibles tienen en el mundo una individuación espacio-temporal” (1954, p.368) y dado que no solo presenciamos ese espacio-tiempo a través de las estatuas, son ellas las que nos hacen participes de su individualización, pero el nombre de esa individuación es la que estamos buscando, esa “objetividad ideal", esa esencia originaria y auténtica de la escultura agustiniana es la que permanece por ahora invisible a mis ojos y de lo cual solo tengo un sentido derrumbado en el desplazamiento del lugar de origen y en la intervención del espacio que ha buscado preservar la monumentaria.

Aquellas estatuas, tenían un lugar en el que habitaban bajo tierra, tenían su casa y con ella, el sentido de su origen y nacimiento. Pero al ser sacadas a la luz, por guaqueros y arqueólogos su casa fue trasladada a lugares artificialmente creados en el marco de un parque temático, ahora tiene su lugar como puesta en escena de un espectáculo del turismo que los ubica para el consumo cultural. Es decir que su casa y por ende su sentido originario como expresión de un pueblo se ha desvanecido y se ha trastocado en el desplazamiento. El desplazamiento del sentido originario hace que solo queden huellas o simples rastros difusos de lo que significaban, haciendo que el silencio se agudice a la hora de dar enunciados sobre su posible esencia, y solo se quede en un enmudecimiento de la obra de arte, como diría Gadamer.

Un experto en arte escultórico, habla de "los principios esenciales de la buena escultura" y uno de ellos, es que los maestros que esculpen "le den vida mediante la flexibilidad de la superficie y no por la cantidad de detalles" (Read, 1994, p.40) Por tal razón en el suelo, la superficie, el lugar es lo más importante de la escultura, y es precisamente lo que se ha perdido en el desplazamiento de las estatuas de San Agustín. El lugar donde se encontraban originariamente hablaba del sentido de su vida pero se le ha quitado la vida. Se le ha quitado su esencia y se le han impuesto otras.

El "dios sol", también ha sido desplazado, actualmente ocupa un espacio, tiene un puesto en el llamado "Bosque de las estatuas" su lugar artificial, este dios está en un lugar, pero el lugar originario ha sido arrancado como quien saca las raíces de un viejo árbol que se quita para instalar una farola, algo nuevo, que perdiendo el sentido de vejez pierde su historia. 
En esa dirección solo encuentro que las esculturas agustinianas han perdido su origen, ha sido arrancado, desplazado y en ese desplazamiento su sentido ya no está.

En el recorrido del parque arqueológico, de sus Mesitas A, B y C, paso de largo en este instante otras tantas esculturas que se van cruzando en mi recuerdo, con el afán de llegar a un lugar ritual, la fuente del Lavapatas, un sitio en el suelo tallado con 34 figuras entre serpientes, monos y rostros humanos, formando un laberinto donde la quebrada fluía antaño, pero que hoy está erosionada por la falta de agua canalizada artificialmente y por la cubierta de tejado metálico que desfavorece la apreciación de esta arquitectura única en su tipo. La llamada "fuente ceremonial del Lavapatas" es cada vez menos ceremonial y menos fuente, el agua ya no cubre sus figuras y la piedra se desgasta, como si en vez de proteger un patrimonio, lo destruyéramos. Y en vez de entenderlo, lo usamos según nuestras convicciones, lanzando monedas a los pequeños pozos que se hacen con agua lluvia y pidiendo deseos a la manera del mono de la pila. (Ver foto5 e Imagen 5- 6).

En mis convicciones me imagino un agradable baño de domingo en esa fuente, porque parte de una descripción es también la fantasía, "la ficción constituye el elemento vital de la fenomenología, como de toda ciencia eidética” (Husserl, 1949, p.158) quizá el sentido de la estatuaria sea más simple del que nos elaboramos en hipótesis, buscando ver siempre algo extraordinario, más allá de lo posible, porque creemos que todo aquello que no pertenece a nuestro mundo siempre tiene algo especialmente increíble, juzgamos con la idea de mayor o menor civilidad humana, más bárbaro o más avanzado, más sagrado o más profano.

De allí que, el desplazamiento no sea el único factor de la pérdida del sentido auténtico de la escultórica, también las interpretaciones de los expedicionarios de todos los tiempos que han determinado un nombre a las estatuas. Nombrar es designar cualidades a las cosas y los nombres de la estatuaria han dejado una marca indeleble en la interpretación de las esculturas que no permiten ver con nuevos ojos a cada una de ellas, desviando toda posible investigación fenomenológica. Enunciar unos nombres es ya una forma de darle cierta verdad a las cosas, ya que califica y juzga lo que es el la obra. Heidegger llama a este enunciar, proposición, indicación, predicación o manifestación, (2002, p.173) que parece estar unida a las cosas de tal manera que el solo nombre: "dios sol" y "doble-yo" se 
convierte en un lugar posible de verdad que sobrevive con el tiempo, pero que no constituye un lugar originario de la obra.

Vuelvo a mi recorrido mental, subo al Alto del Lavapatas a unos $1750 \mathrm{mts}$ y en la cima me encuentro en una experiencia con un falo de piedra postizo. Pequeño falo que seguramente escandalizó la vista del cronista Fray Juan de Santa Gertrudis en 1757 al decir que eran “obras del demonio", o al preso fugitivo, José María Espinosa en 1817, al encontrarse con estatuas "como mujeres de las cariátides en Grecia, pero un tanto más desabrigadas", razones que sobreviven en las concepciones quizá religiosas o de un velo moralizante.

La escultura agustiniana es vista como mágica, pero también como simbolismo demoníaco, interpretada como visiones pintorescas de las zonas amerindias, idea de los cronistas de la época colonial, que atribuían esas expresiones del arte con un bajo nivel de moralidad. "En los pueblos americanos la plástica y la decoración se entrecruzan y se confunden con el simbolismo religioso, los conceptos estéticos se confunden con magia, pero no como sucedió en las primeras manifestaciones artísticas, sino a consecuencia de la decadencia moral originada por el desarrollo de magia" (Pérez de Barradas, 1943, p.142).

Esta mentalidad lleva a que los visitantes o habitantes de la zona, rompan las piedras o todo lo que se asemeje a falos erectos o que luego son restauradoras con incrustaciones de cemento (Ver foto 6), como quien remienda con lana roja un traje de seda blanca. Aquella escultura es el conocido "doble-yo" nombre dado por el arqueólogo Preuss, seguramente influenciado por el naciente psicoanálisis freudiano y por lo cual hasta nuestros días se explica este tipo de figuras con un "alter-ego" que en forma de un animal se alza sobre su cabeza dotando de "poderes sobrenaturales" a quienes lo poseían, ya que era una forma de hacer presente ese otro mundo de "la vida de ultratumba" (Ibíd. 1943, p. 144) Sin embargo, el "doble yo", incólume, con su rostro de frente y un lagarto sobre él, deja ver la piel de ese reptil que va desde la cabeza resbalándose por toda su espalda, y que a la altura de sus rodillas en la parte inferior y sin cola, deja ver el rostro de un felino.

Esa imposición de nombres también pasa con aquellos asociados al credo de la iglesia católica, que fueron dados por cronistas y frailes, que al ver estatuas tan inmensas se escandalizaban o se asombraban, las bautizaban como reflejos de una vida sagrada pero de una religión profana. Es el caso del fray Juan de Santa Gertrudis, que enviado a buscar el 
añorado "dorado", junto con mestizos que hacían de guaqueros no encontró "oro ninguno, solo un zarcillito muy chico", y describía sin mucha importancia "una canoa larga de siete varas toda de una pieza... tres obispos de medio cuerpo hasta la rodilla... cinco frailes franciscanos observantes, de las rodillas para arriba labrados de la misma piedra que los obispos.”(Sánchez, 2011, p.21) Está hablando del conocido Obispo, (Ver foto 7, Imagen 7) que por su tocado en forma triangular y como si oficiara un bautismo le dieron el nombre que hoy es debatido. Pero las interpretaciones llevan a pensar en un partero, en el acto de un nacimiento, una cesárea, en todo caso una figura masculina, o masculinizada que recibe a un niño.

Ello no es extraño, algunas estatuas que muestran ciertas acciones son nombradas en su forma masculina, pero donde otros ven mujeres algunos expedicionarios vieron obras propiamente masculinas, como por ejemplo "el flautista". (Ver foto 8) escultura que encontró Codazzi y fue reencontrada por Pérez de Barradas el 16 de abril de 1936, de la cual se habla como una "figura con una nariz larga" (1943, p.164) pero cuya referencia sigue siendo masculinizada en su nombre.

Es curioso ver que las pocas esculturas denominadas en su género femenino, única y exclusivamente, se reseñan cuando se evidencia un embarazo con su vientre abultado, como el caso de la escultura a "la maternidad". (Ver foto 9) o solo porque lleva un niño en sus manos, como la "diosa que muestra un niño" (Ver foto 10). Quizá el hombre ve estatuas masculinas y las mujeres estatuas femeninas. Lo cierto es que no es claro el por qué a algunas esculturas las llaman femeninas y a otras masculinas. En definitiva percepciones distintas del mismo objeto con base en representaciones previas a la obra misma, que rigen en la mentalidad de la vida de quienes las percibieron y de los juicios morales, religiosos o científicos de quienes las nombraron.

La nominación impositiva también se da en el nombre de San Agustin, cuando los pobladores que antes fueron inmigrantes provenientes del Cauca y Nariño, contaban con un solo latifundio, de tierras fértiles cuya hacienda se llamaba "San Juan de Laboyos" perteneciente entonces a Doña Francisca de Calderón y a su esposo el capitán Don Agustín de Valderrama, quienes hacia el 1730 poseían lo que hoy es San Agustín, San José de Isnos 
y la mitad de Pitalito. (Freide, 1948, p. 33) y en cuyo territorio está la más importante riqueza arqueológica de la zona y por el cual fue dado este nombre, en honor a tal capitán.

Por su parte los montículos, los sarcófagos, tumbas y dólmenes, yacen en las planicies, montañas y altos, sin cadáveres y sin nadie que lleve flores. Lugares que profanados por guaqueros, expedicionarios y arqueólogos sacaron vasijas y adornos en oro que los acompañaban en ese posible viaje a otro mundo. Nosotros lo llamamos profanación y saqueo, pero en su tiempo era una forma de recoger evidencia investigativa para contribuir al conocimiento, como se aprecia en una fotografía de la sepultura número 1 de la parte oriental de la mesita B. (Imagen 7) pero no solo aquellos académicos saquearon las tumbas, también los pobladores de la región rompían muchas piedras creyendo que dentro de ellas había oro, lo cual se sabe por historias que se cuentan en voz baja.

El San Agustín escultórico, ha tenido una desterritorialización originaria, muchas de las obras encontradas espacialmente en distintos lugares han sido cambiadas, trasladadas de su lugar de excavación, trastocadas y arrancadas del suelo en que fueron talladas, quitando el sentido de todo el sistema simbólico bajo el cual fue construido para ser ahora organizado bajo el sentido del comercio turístico y por defecto para permitir, el saqueo y robo por parte de extranjeros, guaqueros y comerciantes ilegales de antigüedades.

Me detengo, tomo un sorbo de este café del Quindío que se va decantando en mi vaso. La historia de la estatuaria de San Agustín está basada en los preconceptos de cronistas, expedicionarios, arqueólogos, Generales, hombres que escribieron noticias de la escultórica, y es esa la que nos permite rastrear más que la esencia en sí misma de las obras, la esencia de la mentalidad que ha regido en nuestra cultura frente a la cultura primitiva ancestral precolombina, una visión religiosa que distingue lo sagrado de lo profano, una visión masculinizada de las obras, una visión mercantilista del consumo cultural, una visión utilitaria mostrada en saqueos, en conclusión lo más visible que se ponía ante mis ojos como invisible es que la escultura es lo impropio de nuestra cultura. Nunca ha existido una apropiación de la escultura, no hay un lugar originario ni auténtico, no es olvido porque nunca se ha recordado como propio, siempre como Otro, como lo extraño, lo diferente, siempre viéndola bajo el lente colonizador. 
De allí también que el enigmático "doble-yo", que se halla en la cima del camino desde el cual se divisan las montañas y en el fondo el Estrecho del Magdalena, es según los guías, un lugar energético en el que se descalzan los visitantes para descargar "malas vibras" y cargarse de otras buenas, como si fuera parte de un acto ritual, desprovisto de una institución religiosa pero consagrándose a un esoterismo de la "new wave", a conexiones cósmicas y a viajes energéticos, algo totalmente ajeno al tiempo y lugar de la escultórica.

Así como el "dios sol" ha sido desplazado de su sentido originario, a nosotros como colombianos nos han desplazado el sentido del estar anterior a la colonización, nos han arrancado esa historia precolombina como nuestra a tal punto que la vemos como otra, como ajena distinta a nosotros, y no como el rostro de nosotros. La obra tiene un modo de ser propio, ser un dios solar-otro, que tiene un lugar otro, donde se le reconoce como lo otro, peor ello solo puede entenderse desde la tematización de un lugar -no lugar, un Lugar-Otro, un origen-no origen. Desde el cual solo podría leerse el fenómeno de la escultura agustiniana. 


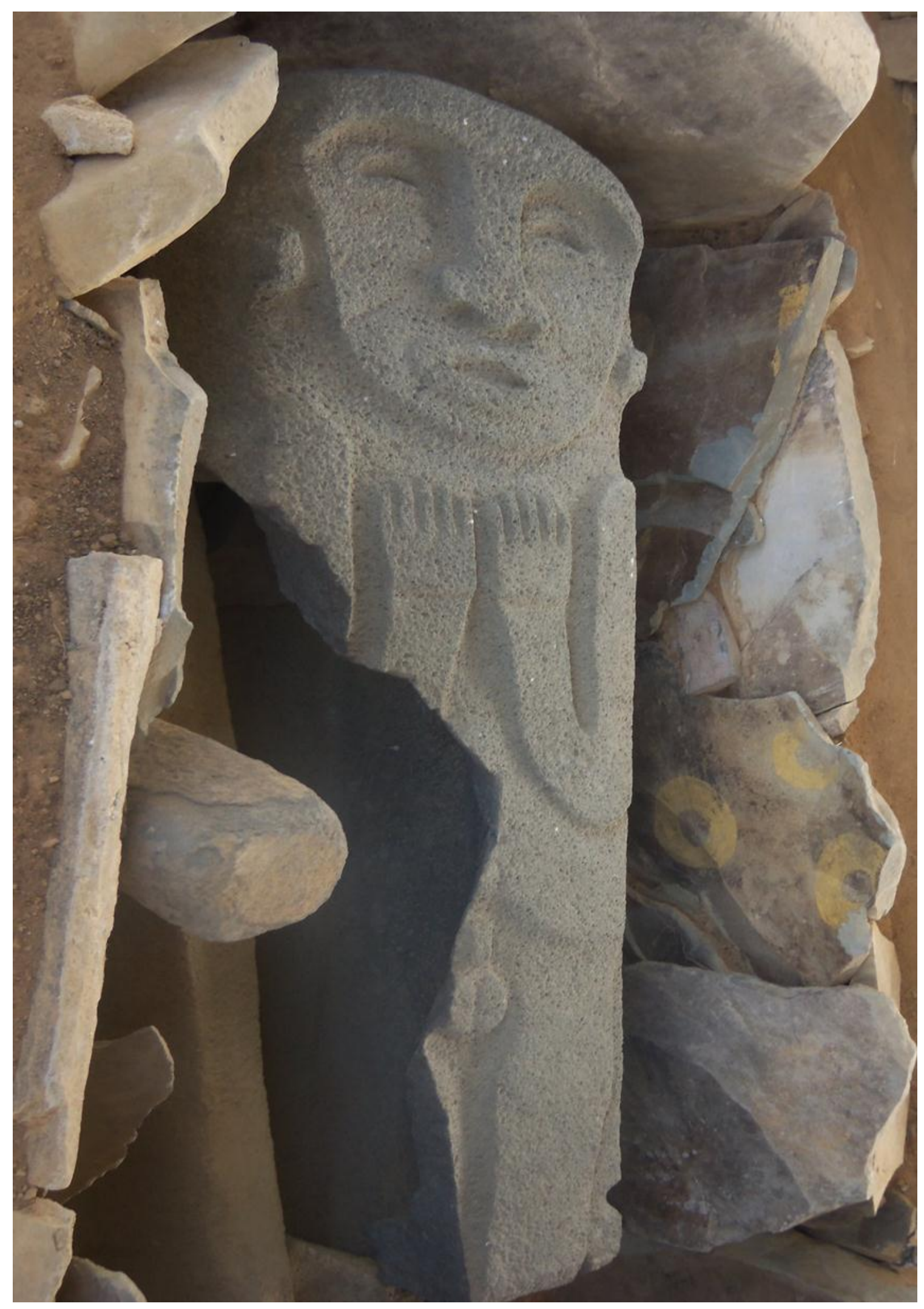




\section{CAPÍTULO III}

\section{LA ESCULTURA AGUSTINIANA COMO LUGAR OTRO}

Ante el derrocamiento del sentido originario de la estatuaria agustiniana y luego de una investigación retrospectiva que gradualmente me llevó por el camino de una actitud y un ánimo escéptico frente a los postulados dados por parte de los investigadores, solo queda partir de ese no-origen, propio de la escultura, que como un punto de partida me permite postular un nuevo sentido, que declare otra posible esencia que obedeciendo a tal condición, permita ver la estatuaria desde otro horizonte.

Debido a la evidencia del derrocamiento del sentido auténtico y originario, el conocimiento que puedo tener de ellas es deficiente, esto, debe entenderse en el sentido fenomenológico de que "el conocimiento auténtico, auténtico en el sentido de la verdad conceptualmente rigurosa, y los entes, en un sentido verdadero, llegan a ser correlatos" (Husserl, 2012, p.22), no hay por tanto un conocimiento auténtico ni un correlato único que sea la esencia verdadera de la escultórica. Y por tanto la declaración como parte del método permite postular una esencia que constituya un sentido universal del ejemplar dios sol y de todo lo relacionado con él, su espacio y las otras obras.

Hablo del derrocamiento porque lo esencial se ha perdido en el tiempo y se ha arrancado con el desplazamiento de las esculturas, lo que genera un giro de lo que era en sí misma, frente a lo que podría ser. Se ha realizado un derrocamiento de las opiniones antes establecidas sobre la escultórica y todo aquello que ha pretendido ser una idea o conocimiento "verdadero" de su origen se pone entre paréntesis. Los sentidos impuestos no le pertenecen a la estatuaria, no le son propios, han sido imposiciones de sentido que en su historia se han tomado como verdaderas. Por ende no hace parte de un posible sistema de significado, desde el cual pudiera formular una esencia, solo hay un dios solar, unos dobleyo, una flautista, unos testigos, unos "chamanes", sarcófagos, tumbas, pero de las cuales nada puede decirse con certeza, quedarme con esas ideas místicas y científicas, sería 
quedarme con "un conocimiento ingenuo de las cosas" (Ibíd., p.24). Ahora es preciso postular una posible esencia de aquellas esculturas y mostrarla claramente, desde lo universal.

La escultura está situada, tiene una locación, un lugar físico al que podemos ir, visitar y estar en él. Allí, cada estatua ocupa un espacio; en términos fenomenológicos, hay una constitución del lugar dada por la relación entre "cosa y espacio"30 (Vargas Guillen, 2010, p.52). Sea que estén fijas o en desplazamiento, las esculturas están en un espacio, se espacializan. $\mathrm{Y}$ ello es posible porque hay un cuerpo que permite ocupar un espacio. Un cuerpo de piedra, pero también un cuerpo viviente que lo percibe como tal.

Es importante aclarar que este cuerpo espacializado no es una cualidad que yo como sujeto le doy a la cosa, sino que le pertenece en este caso a la escultura misma, “...la percepción contiene un momento de extensión; pero esto podría ser una perversión fundamental para reclamarlo como extendido, esta palabra, como sentido solo aplicable a las cosas: lo que designa cierta modificación espacial. El espacio es una necesidad que proviene de las cosas y no de la experiencia vivida, específicamente, no de la vivencia sensorial. Que "venga de la intuición”, es fundamentalmente una expresión falsa...” (Husserl, 1997, p.37) ${ }^{31}$ que la escultura tenga extensión y por tanto se despliegue en un espacio, implica que tiene un cuerpo que le es propio, que hace parte de sí misma.

En este sentido, cada cuerpo espacializado, cada escultura y cada sujeto que la percibe, es un mundo posible y "todo ser posible, en general obedece a la ley de la dispersión” (Henry, 2010, p.25), en el cual caben abiertamente diversas ideas y sentidos. Entre el sujeto y la escultura, entre la obra y yo, se da también un mundo. Ese "entre" es un espacio común

\footnotetext{
${ }^{30}$ Texto de Husserl, Ding und Raum, 1907. Den Hague. Martinus Nijhoff, 1973, p. 285 ss. que es citado en español por Germán Vargas Guillen.

${ }^{31}$ Tomado de la versión inglesa "Thing and Space" que textualmente dice: "The perception contains the moment of extension, but it would be a fundamental perversion to claim it is extended, sense this word, by its very sense, applies only to things: it designates a certain spatial modification. Space it's a necessary from of things of lived experience, specifically not of "sensuous" lived experiences. "from of intuition" is a fundamentally false expression ..."
} 
que es compartido por las cosas y el sujeto, por la escultura y el espectador activo, de tal manera que la escultura hace parte de un lugar de la intersubjetividad, como si se tratara de otro sujeto con el que me relaciono en el mundo donde nos comunicamos la estatua y yo, “... la percepción que quizá no está en mi cabeza, no está en ninguna otra parte sino en mi cuerpo como cosa del mundo" (Merleau- Ponty, 2010, p. 22 ).

En ese espacio del cuerpo de cada uno y en ese lugar común entre ambos, se crea un lugar otro. Un lugar posible. Ese lugar otro, implica que la actitud del espectador cambie radicalmente al contemplar la obra y que la vea como parte de su propia existencia espacial. Al situarse en el mismo lugar de la obra, no como externo sino como parte de ella, se comprende que la escultura agustiniana y el espectador activo, guardan una relación intrínseca: que son cuerpo y son mundo.

La obra deja de ser una cosa externa y pasa a ser un sujeto de relación. La obra cobra vida en la vida del espectador. Los límites que demarcaban el cerco en el Parque San Agustín, se rompen no al cruzarlos evitando la sanción de un guardia, sino al cortar la barrera entre la obra y yo, al desdibujar la idea de que es una cosa extraña, ajena a mí, y que por el contrario somos un solo mundo. No solo es la tridimensionalidad y las características simétricas o asimétricas, el color, la textura, sino la sincronía de dos cuerpos que interactúan en un mismo espacio. En este vínculo esencial, no solo hay una relación artística y material, sino que se constituye un mundo, parte de mi misma, que le da sentido al propio mundo, un mundo que experimento como mío, del cual hago parte de esa comunidad, y por tanto es trascendental.

A este respecto, la esencia ya se ha mostrado, ha sido enunciada. La esencia de la escultura de San Agustín es ser un "lugar otro". Es un lugar al que se le ha arrancado su sentido, origen y autenticidad, por lo cual se hace necesario postular un nuevo sentido que permita verla con otros ojos. Dice Husserl, “es cosa manifiesta que yo sólo puedo aclarar la esencia del conocimiento si la veo por mí mismo y si me da a la vista ella misma tal como es" (1982, p. 57) y la escultura agustiniana se me da como un lugar posible en tanto cuerpo y esto es algo evidente que no es posible evadir con la simple suposición de sentidos no originarios. 
La ausencia de sentido que se describió en lo visible e invisible de la escultura que arrojaba a un silencio y enmudecimiento frente a la obra, lleva a la necesidad de enunciar otro sentido. Pero aquel nuevo sentido que se constituya solo puede darse en referencia al espacio vital de la obra, que por supuesto, no supone uno absoluto y determinante, pero que al postularlo como un lugar otro, revela un posible carácter distinto a los que se le han impuesto, una perspectiva otra que no sucumba en los discursos repetitivos de antaño. Y así mismo, aquel que vea la obra, la contemplará como un lugar específicamente diferente a los demás que se pueden ver en museos, exposiciones de arte, en caminatas ecológicas o en un ecoturismo actual.

El espectador y la obra como cuerpos espacializados se correlacionan mutuamente en ese espacio otro. Al tener ese encuentro, comparten el mismo sentido de algún mundo posible. Dado que el sentido originario en la escultura de San Agustín ha sido derrocado a través del desplazamiento, la nominación impuesta, los saqueos y la masculinización, solo nos queda la obra sin tiempo, sin espacio, sin sentido auténtico, pero ello permite a su vez constituir ese lugar otro, desde donde sea posible ver universalmente un mundo de la escultórica, partiendo de una base corporal evidente, cuya corporalidad hace que la obra se haga visible para mí y donde me hago visible para ella.

Como lugar Otro, San Agustín es un mundo posible, donde puede tenerse de él un conocimiento posible. Lo Otro, debe entenderse aquí como lo posible, pero también como lo inclasificable, fluctuante, permeable, inestable, variable. Por su parte, "la propiedad más característica de lugar es que se ofrece siempre como un ahí” (Vargas Guillen, 2010, p.63), un espacio que intencionalmente puede ser un sueño, una irrealidad, una fantasía, un terreno de sentido, un mundo material y corporalmente cargado de algún sentido universal.

Un lugar otro, sería un lugar posible que no se haya imaginado, o que siendo imaginado tenga múltiples sentidos, que me permitan tener una experiencia posible y con ello, seguir la pretensión fenomenológica que permita "la fundación para la determinación universal de temas posibles de las ciencias del mundo como para regiones todo-inclusivas posibles y como para posibles investigaciones dirigidas hacia los contextos-mundo" (Husserl, 1962, 
p. 162). Ese sentido posible y características espaciales se dan al estar en y estar con la obra. Pero estas dos formas de encontrarme con la escultura se dan en un espacio determinado, en unas condiciones anímicas específicas, sea como una utopía o como una heterotopía.

\section{1 La utopía del sentido germinador de la escultura agustiniana.}

Estar en la obra, es estar en un lugar utópico. El lugar utópico constituye un espacio como una puesta en escena de lo que pudo haber sido, lo que puede ser y lo que se quiere ser, aquello de lo que desde la fantasía se puede vislumbrar como lugar de ensueño y anhelo, más allá de lo que presenta el mundo habitual y cotidiano. Este espacio se rige por un orden aparentemente dado por su propia estructura, pero que posee la imprecisión de un orden que le ha sido impuesto y por tanto tiene "la posibilidad de ficcionar lo que aún no existe” (García, 2006, p. 65), quizá también tenga razón el especialista en arte escultórico Read, al decir que "los orígenes del arte se pierden en la prehistoria y para reconstruirlos, debemos proceder imaginativamente, no científicamente” (Ibíd., p.31).

Por su parte, Foucault llama a este tipo de espacios, utopías; porque siendo un lugar real o irreal, crean espacios irreales, donde la perfección tiene su existencia. Como el sueño, el paraíso, el cielo, son u-topía, lugares no-lugares, un lugar sin lugar, permiten construir un horizonte nuevo de sentido, cambiando las condiciones para el presente. "Estas utopías son espacios fundamental y esencialmente irreales" (1999, p. 434) y que por ejemplo "alojan en el interior las posibilidades míticas de la cultura" (Ibíd., p. 289).

En términos fenomenológicos, serían lugares cuyo ahí poseen muchas interrelaciones, multiplicidades ordenadas pero que crean un horizonte puro, de un lugar puro ahí de condición óntica (Guillen, p. 64) que se percibe como una vivencia real, pero que no es una percepción inmanente de la cosa, (Husserl, 1997, p. 48), sino que son objetividades ideales, como menciona Husserl en El origen de la geometría y que, como las figuras geométricas, son cuerpos puros (que tienen) "configuraciones espacio-temporales y cualidades materiales (color, calor, peso, dureza)" (Husserl, 1954, p. 384). 
Las esculturas agustinianas son esas utopías, reflejo de un posible proyecto de realización humana puro, producidos por sujetos como si se tratara de productos espirituales (Husserl, 1954, p.367) de un pueblo escultor, que materializaron la idea de un mundo primitivo en la piedra, pero del cual solo existe la obra sin autor, sin nadie a quien remitirse, más que a una comunidad que compartía un mismo sentido del mundo. Así queda la obra escultórica como el testigo de ese pueblo y es ella la que habla de la cultura y del mundo de su comunidad, ya perdida y extinguida en el tiempo.

Estar en una escultura agustiniana, supone habitar esa u-topía estando en un cuerpo ajeno, en su carne, sintiendo lo que ella siente, viendo con sus ojos y desde allí, construyendo un posible orden del mundo, un posible sentido del mundo. En ese allí, en ese en, me apropio de la obra misma y la obra se apropia de mí, como si fuéramos parte de un mismo cuerpo. Las esculturas agustinianas en tanto utopías, ven el mundo a través de su propia visión, desde lo que podría llamarse la mentalidad de los primitivos, la cual está fundada en la relación hombre -mundo.

Ese hombre de la cultura agustiniana se hace patente en la escultura, ella es el hombreescultura y el mundo que lo circunda. Así pues, siguiendo a Husserl, hay una necesidad de ver estas realidades primitivas, "como personas, como sujetos de conciencia, tal como se encuentran a sí mismos en concreto..." (1995, p. 172) y por relación, la mentalidad de los primitivos debe entenderse como la mentalidad de nosotros mismos en tanto seres humanos universales.

Ha de aclararse aquí, que primitivo no se refiere en el orden de un progreso, a lo más básico o lo menos civilizado. Categoría que se usa para determinar todo arte rupestre o el arte tribal bajo, "la idea [de que] el arte primitivo nace como una espontánea emergencia de energías vitales, lo que es realmente obsoleto, y mucho más obsoleto es el corolario de la idea de que las culturas tribales nos mostraron un hombre en una forma de desarrollo, una reliquia de la mentalidad salvaje, la cual nuestra cultura ha creído tener sobre el pasado, en relación con el estado presente del mundo civilizado" (Gombrich, 2006, p. 269). 
La idea de lo primitivo podría aplicarse a cualquier lugar u objeto que se refiere a lo primigenio y se pregunta por problemas fundamentales que atañen a toda la humanidad, en todo tiempo y en todo lugar, o por lo menos competen a un "problema correlativo: la unidad de una vida nacional cerrada y el mundo ahí concreto lleno de vida para la nación y real para ella, con su típica estructural” (Husserl, 1995, p.173).

Cuando se habla de una mentalidad se trata de la lógica que se comparte o con la cual empatizamos como parte de un mismo mundo o como un mundo otro al que nos referimos como nuestro, como un "nosotros". San Agustín no es un lugar ajeno a nosotros como país, somos San Agustín, somos las esculturas, somos parte en cuerpo y mente de ese espacio, de ese topos. Y nos afecta directamente, sea en empatía o antipatía, lo que puede ser o significar la escultura agustiniana. Nos genera una afección en tanto seres humanos en un espacio y en una cultura, porque nos habla de nuestro mundo y nuestra historia, bajo la idea de "mundo y nosotros hombres en el mundo" (Ibíd., p. 174).

Esa afección que Husserl llama empatía (en la carta a Levy Bruhl) también puede entenderse como un "impulso", una motivación, una intencionalidad, un "impulso germinal" diría Merleau-Ponty, a la que la obra nos llama, como si ella misma se proyectara en un telos. La escultura agustiniana es en sí misma una proyección de humanidad, nacida en el seno de un "impulso" incomprensible para nosotros y del cual tenemos una huella, un rastro sin texto, sin bibliotecas, sin escritos, sin historias, huellas que no sabemos a dónde conducen ni por qué se hicieron, solo huellas que nos llevan por el camino de la investigación de la huella en sí misma.

Empatizamos con la escultura de San Agustín, de un mundo que existe para la vida de una humanidad. No como una representación de cosas y transcripción de eventos, sino como parte vital y unidad de un mundo en su origen. Estando en la obra escultórica me pregunto por su historia, “Así como nos planteamos la pregunta por su historia desconocida y con ella la pregunta por nuestros antecesores desconocidos, por su vida y sus intrigas, su mundo circundante desconocido, por su desarrollo y eficacia en los cuales nuestro mundo ha llegado a ser por obra de una continuidad histórica, de una continuidad temporal histórica, por obra de la historia de los hombres, pero también de la historia natural" 
(Husserl, 2008, p.162), como si el pueblo escultor hubiera tenido una razón teleológica para existir y por la cual sobrevive para hablarnos de esa lógica en la actualidad, lógica que es posible "transmitirse y reproducirse en un sentido intersubjetivo" (Husserl, 1954, p.385) que nos comparte y del cual somos partícipes porque nos habla de la razón del pasado, que configura nuestro presente y determina nuestro futuro como sociedad.

Como toda sociedad, "no tiene por así decirlo un mundo fijo, sino un mundo que en parte tiene como futuro realizado (pasado nacional), en parte un futuro que hay que realizar como un futuro que está por configurar según las metas nacionales” (Husserl, 1997, p. 173) y Colombia no tiene un solo pasado nacional, tiene muchos mundos que no son fijos y determinantes, y por tanto, no determinan el futuro, el cual se configura en la medida en que se vislumbran otros mundo internos en nuestra historia.

Toda historia de un pueblo tiene un inicio. Una historia del génesis. Y ese génesis es una Utopía de la que hablan las esculturas agustinianas y remiten a un origen reproductor. Una génesis de la vida humana como ese estar en el lugar inicial donde existe no una "representación del mundo" sino "el mundo realmente existente para ella" (Ibíd., p. 173) que tiene según su espacio y tiempo, un mundo unitario, donde se relacionan los aspectos de la vida en comunidad.

En la escultura agustiniana, ese inicio se da a través del falo germinador de un pueblo. El poder masculino. El lugar de inicio de esa historia natural la veo nuevamente en la estatua del "doble yo", que se repite en otras de falos erectos, mostrados naturalmente. Recuerdo la referencia de Hegel cuando afirma que "los primeros monumentos fueron fálicos" (Reader, 2009, p. 31); el falo, se presenta en esta utopía como pilar de la germinación de la vida que habla del comienzo de un pueblo, el cual, en forma de tótem, crea una especie de culto a un "ídolo", quizá una expresión imperecedera de una institución de poder y afirmación de ser y estar en un mundo de cierta manera.

Esta expresión fálica de la escultura es un lugar quizá de culto, donde no se oculta el miembro sino se exhibe en forma de altar o adoración a aquel que lo muestra en su estado de erección, y que se puede catalogar como poderoso, "la mayoría de los arqueólogos están 
de acuerdo en que la mayor parte de los objetos tallados que sobrevivieron a los tiempos prehistóricos, son objetos de culto: actualmente llamados “ídolos” (Read, 1994, p.54).

Sin embargo, la idea de ídolos se confunde en la actualidad con una falsa sacralización. Y por el contrario, aquí tiene el sentido de un profundo respeto en el orden de lo sagrado, así como en otro mundo sería la adoración a ciertas imágenes religiosas que tienen poder entre los creyentes, formando una institucionalidad en el orden de la vida cotidiana de los hombres. Esas expresiones falocéntricas de varias esculturas monumentales de San Agustín, evidencian un sentido espiritual de un mundo de la vida relacionado con un posible rito a la fertilidad, según la reiterada interpretación de las esculturas primitivas de otros pueblos (Read, 1994 p. 48).

Por su parte, el cuerpo femenino como se ha mencionado, se exhibe en su estado gestante o en acciones de copulación, de esta última en especial, existe un ejemplar en El Bosque de las Estatuas en una distorsión grotesca ${ }^{32}$ donde aparentemente un mono "monta" a una mujer en forma de apareamiento. Pero donde mayormente se evidencia el cuerpo femenino es en la representación del útero. El vientre preñado, el niño en brazos o en rostros sin máscaras con cuerpos inflados en su parte anterior, hablan de la geminación de la vida a través del nacimiento y la maternidad. (Ver Foto 11).

Ese útero al igual que el falo es una utopía. Un lugar que instaura la casa madre, la casa donde nació un pueblo, un útero que parió a sus hijos "primitivos". Y que les dio un mundo donde habitar, donde resguardarse en las altas montañas, arriba de los ríos, en lugares de difícil acceso, en definitiva, un lugar donde se compartían sus propios secretos. Ese útero que también es la matriz de un pueblo, “el árbol de la vida, (que) está preñado de casas, esferas y subjetividad humana" (Sloterdijk, 2009, p. 340).

Ese útero fecundado que se repite en la escultórica agustiniana, muestra ante el espectador algo evidente, según Sloterdijk, donde el observador "no tendría que testificar más que lo que por sí mismo tiene que aparecer a la luz en la salida de la caverna, en el drama siempre

\footnotetext{
${ }^{32}$ Es la expresión que usa Herbert Read al hablar de la escultura tribal.(p. 60)
} 
drástico y sublime del nacimiento" (2009, p.341), es decir, el nacimiento como un acontecimiento humano universal de todos los tiempos y pueblos que marca el inicio cultural.

En el espacio utópico de la germinación cultural, tanto el útero y el falo, muestran una cosmovisión y sentido de humanidad que responde a un aspecto universalmente dado en el nacimiento de la vida y la reproducción, vistas no como temas banales y meramente coitales, como algunos podrían calificarlo, sino que son esculpidas en su carácter más preciado y estético, donde no solo es una copia o mímesis de la realidad, sino donde el escultor también ficciona su mundo-entorno, plasmado en la talla.

Hablo de la vida y el mundo-entorno, porque esta también se expande en las esculturas de seres como ranas, serpientes que habitan el agua, micos y felinos que habitan la tierra, aves que surcan los cielos, animales que se repiten en el camino por la mesita B y van hasta el Alto de los Ídolos, significando algo más que su animalidad silvestre, como si se tratara todo ello de algo vitalmente importante y determinante en ese culto a la fertilidad y a la vida.

Esa vida germinadora se difunde en otros elementos como los oficios cotidianos. Husserl en Renovación del hombre y la cultura, habla de que "el mundo entorno, el mundo de la vida es como el sujeto mismo", y así como es el mundo-entorno de San Agustín, con sus esculturas y "representaciones espirituales", así mismo eran los sujetos que lo habitaban. Aquel pueblo, tenía oficios, ocupaciones; entre ellas, la que más nos consta en evidencia, es el esculpir, tallar y pintar unas «piedras», como quien escribe sobre el papel donde consigna todo lo que siente y piensa.

Y ello es relevante porque "la forma escultórica no es meramente una cuestión de capacidad técnica sino que en gran medida puede estar determinada por consideraciones conceptuales, de origen religioso o social" (Read, 1994, p.57) y ahora pienso que más importante que la razón que motivara el esculpir, está la idea de la maravilla de darle cuerpo a los pensamientos, darle vida en esa «piedra» y que como las demás expresiones humanas, un lugar de la escritura, un lugar donde se expone una cosmovisión, donde se 
afirma o se niega un mundo, donde se crean otros, donde se muestra la existencia de una comunidad, su inicio y final, su germinación cultural, por la cual según su tamaño y detalle, se hace más relevante para un grupo de hombres.

En este lugar "cada piedra que haya sido tocada por la mano de un maestro se suaviza con una vida subyacente, asemejándose a la naturaleza no solo en la textura superficial o en las nervaduras de una hoja o en las venas de la carne, sino en la amplia, inexplicablemente sutil ondulación de su forma orgánica” (Ibíd., p.4). La roca, quizá volcánica, encontrada en El Estrecho del río Magdalena, trasladada, puesta y dispuesta de cierta manera y en ciertos lugares, es la forma originaria de la expresión de un pueblo, casi como una necesidad por mostrar de algún modo su mundo-vital, su cosmo-visión, donde la escultura sería una de esas formas de escritura que habla de ese mundo, la escritura en roca, escritura en imagen, escritura en escultura, "a parte de los ritos de fertilidad y de otros usos mágicos, el hombre necesitó originariamente a la escultura como medio para establecer un sentido de existencia real"(Ibíd, p. 50).

Todas esas obras tienen un valor viviente y vital, que no puede juzgarse como mejor o peor según nuestros preconceptos, sino que encierran la posibilidad de pintar: "[esculpir] en [la piedra] la debe pues, a la naturaleza de su ser tal como le ha sido dada, y por tanto la naturaleza del ser mismo" (Henry, 2008, p.11) esa es la razón más universal de porqué esculpir, pintar, dibujar, danzar, escribir y es la necesidad del ser, que como fundamento de toda creación, está ligada a la posibilidad misma de tratar de comprender la propia existencia como individuo y como parte de una comunidad.

Podría decirse simplemente que son obras y hechos materiales, donde la técnica y la forma definen al objeto creado, relacionado con el uso de herramientas y transformación de los materiales. Pero no responde simplemente a la experticia en un arte. No es relevante la técnica ni el instrumento, no importa si son asimétricas o simétricas, sino, lo que universalmente demuestran en el mundo de lo humano.

Quizá haya algo universal en todas las culturas ancestrales que esculpieron, algo que no tiene que ver con vuelos espirituales ni consumo de plantas alucinógenas, ni poderes 
sobrenaturales, y es el impulso o "necesidad subjetiva del espacio expresivo: el espacio mismo como símbolo significativo... una conciencia del espacio como tal" (Read, 1994, p.36).

Esa vivificación de lo germinativo de la vida se lleva hasta sus últimas consecuencias y hace que el escultor también visualice un elemento imaginativo, como la zoomorficación, los dobles yo, las máscaras con dientes de felinos en cuerpos humanos, las pieles y caras de lagartos en hombres desnudos como una forma de divinizar la vida, más las capacidades mágicas y poderosas que se pueden otorgar a través de su propio cuerpo, ya que "es concebible que la figura humana pueda corporizar una concepción humana de lo divino" (Ibíd., p.62), ello quizá en un estadio "metafísico" que supone ir más allá de la apariencia de los simples animales y así "entregarnos su esencia íntima", la cual captamos porque nos identificamos con las obras en un acto también ritual y de iniciación de un pueblo que interiorizamos como propio.

Esa utopía de la germinación de la vida, de lo vital de la vida, tiene también su horizonte en la geografía agustiniana. En el salto de Bordones, en las cascadas, en el panorama tranquilo que se vislumbra desde La Chaquira. De allí, que Luis Duque Gómez recuerda la importancia del lugar donde se hallan esas esculturas y que están en el epicentro geográfico vivificador del país: el macizo colombiano, del cual brotan las tres cordilleras, donde tienen origen los cinco ríos más importantes: el Cauca, el Putumayo, el Caquetá, el Patía y el Magdalena.

Este lugar utópico de la germinación se configura por su geografía y por el paisaje que lo acompaña. Con una cuidad de lo sagrado, donde nacen los caudales como el Magdalena, donde el agua cristalina del estrecho se mueve, es vida, ese río que corría antes de la llegada de los españoles y que tenían un nombre, el Huacacayo o Guacacayo ${ }^{33}$ que traduce "río de las tumbas", llamado así por los indígenas del sur del país, según aparece en una

\footnotetext{
${ }^{33}$ Citado así por Hector Llanos.
} 
escritura del 2 de septiembre de 1555 citada por Vicente Restrepo en su Estudio sobre las minas de oro y plata de Colombia.

Un mundo de la vida agustiniana como germinadora de un pueblo es una utopía. Es un lugar que no existe más que como anhelo que tuvieran y tienen los seres humanos al creer que el hombre primitivo poseía una profunda religiosidad, distinta a la nuestra y a la del tiempo de cada explorador que se encontró con la estatuaria. Ese es el sueño de todos los estetas y arqueólogos de creer en un pasado vivificador que se extingue en nuestro tiempo, como tratando de recuperar algo olvidado o extraviado en la historia.

Esa génesis de cualquier pueblo se mezcla con la ficción y la fantasía porque no es posible tener la certeza científica y racional de su verdad. Pero como u-topía, San Agustín es ese mundo posible de génesis nacional, de un pasado anterior a lo que consideramos nuestra historia. Tomarla como un hallazgo significa tener la ilusión de aclararnos nuestro presente y futuro. De allí, que "las utopías consuelan: pues si no tienen un lugar real, se desarrollan en un espacio maravilloso y liso; despliegan ciudades de amplias avenidas, jardines bien puestos, comarcas fáciles, aun si su acceso es quimérico” (Foucault, 2007, p. 3 ).

Esa utopía que tomamos como verdadera se reproduce en los discursos de los guías y académicos, pero nada sobre San Agustín se distingue de lo mítico y lo racional, estos dos elementos se confunden y se mezclan, no importa si vienen de boca de un académico o de un místico, o un guía a caballo, las versiones crean mundos desde lo ficticio creyendo ser científicas. Y así como es una utopía ese mundo germinador, el sujeto agustiniano y el pueblo escultor también lo son. Pero ello permite pensar la necesidad de los pueblos de crear un vínculo consigo mismo y con el mundo-entorno así sea a través de lo mágico y lo sagrado, donde nosotros también lo vivimos como sagrado.

\subsection{La heterotopía funeraria de la escultura agustiniana.}

Mientras estar en la obra es un habitar la utopía que me ha llevado a la idea de una germinación cultural validada en la historia natural de los pueblos por necesidad de vincularse con el mundo- entorno, el estar con la obra me ubica, por el contrario, en una 
heterotopía. La heterotopía desde su propio nombre indica un lugar diferente. Un lugar atrayente, en cierta forma prohibido, misterioso, un lugar que "permite al sujeto estar en un movimiento que lo aleje de su marco de referencia y así, mostrar de qué modo sería posible liberarse de los sistemas que determinan sus conductas más habituales” (Foucault, 1999, p. 38).

El lugar que más nos atrae y que tiene ese velo negro del misterio, que fractura nuestro mundo cotidiano, es el que habla de la muerte. La heterotopía por excelencia es el cementerio. El lugar de los muertos, el lugar prohibido para ser habitado por los vivos. Agustín Codazzi, además de levantar cartografías cuando estuvo en la región de San Agustín, se encontró en su suelo con muchas y diversas tumbas, lo cual llevó a que denominara ese lugar como una "necrópolis".

San Agustín es también una necrópolis. La morada de los muertos. La ciudad de los difuntos. No solo habla de la germinación de la vida sino de la extinción de la vida. Se encuentran tumbas pequeñas, como cajas fúnebres hechas con lajas de piedra cerca a las estatuas, hipogéos en el Museo Arqueológico de Obando, grandes sarcófagos en el Alto de los ídolos en San José de Isnos, y otros en la Mesita B, algunos de ellos tallados con figuras humanas en la piedra que tapa la cuna lítica, ubicada en la parte posterior de las estatuas que parecen custodiarlos, cámaras mortuorias con piedras semirectangulares. Piedras alrededor de las tumbas que están en el fondo de un montículo, desde donde se alcanza a vislumbrar figuras a color. (Foto.12, 13, 14 y 15)

Así como en las demás esculturas hay grandeza, en las tumbas también hay una monumentariedad funeraria. Y al presenciar este lugar, el espectador cae en el embrujo del enigma de la muerte, al estar con las tumbas vacías, se abren las preguntas que cuestionan el valor sagrado de ellas. Con sorpresa se ven unas piedras lizas y planas en unos huecos formando un supuesto ritual sagrado que se halla abierto, expuesto y acordonado. Quizá pensamos que allí duermen unos muertos, pero en cambio vemos piedras sobre piedras en espacios sin cuerpos. Sin rastros de difuntos. ¿Qué pasó con los cadáveres? ¿Dónde están los muertos? 
Solo se encuentran algunos vestigios en el museo del parque arqueológico y otro en el Museo Villa Real. Allí, en esta casa de familia, encontramos un cuerpo completo que yace en su tumba de piedra. Sacado por el padre guaquero de aquel médico que conserva estas reliquias que su madre quiere botar o vender, porque le hacen estorbo. Pero de los demás cuerpos no hay noticia ni evidencia. Según los pobladores Preuss, Freide, Dolmatoff, se llevaron algunos cuerpos y con ellos esculturas, vasijas, cerámicas además del oro enterrado en los sarcófagos y que acompañaba el ritual funerario.

Sin embargo, también es sabido que existieron varios tipos de enterramiento dado el extenso tiempo de esta cultura y sus periodos de desarrollo. En algunos casos, los cuerpos eran incinerados y guardados sus restos en urnas funerarias, de las cuales se conservan en esta casa-museo muchas de ellas en gran tamaño y con inscripciones de puntos y líneas, algunas con colores visibles pero que no sabemos leer.

Otro tipo era el dejar el cuerpo en posición fetal en lo profundo del lecho mortuorio y a su lado por lo general, vasijas llenas de objetos orfebres. (Imagen 8) Luego eran sacados los huesos y guardados en vasijas funerarias, “en este período (formativo) fue una práctica común retirar los huesos de las tumbas después de cierto tiempo y guardarlos en urnas funerarias de cerámica. Estas se colocaban en tumbas de pozo con cámara lateral, a veces con narigueras de oro o de tumbaga."34

El oro que no se ve en las esculturas monumentales y que acompañaban las tumbas ya no está y no brilla. Al parecer en todos los periodos los muertos eran enterrados con figuras orfebres que pertenecían al difunto, por ejemplo, en el periodo clásico regional, en la construcción de monumentos funerarios las tumbas tenían pocos elementos suntuarios además de diademas, collares, vasijas u objetos de madera.

\footnotetext{
${ }^{34}$ Banco de la república. http://www.banrepcultural.org/museo-del-oro/sociedades/san-agustin/en-el$\underline{\text { museo }}$
} 
Lo cierto es que las tumbas han sido abiertas, lo que había allí fue sacado y saqueado, solo quedan algunos ejemplares. Con la destrucción de los santuarios, la idea de que los muertos y las tumbas son lugares sagrados, se ha fracturado. Lo que en la actualidad presenciamos en San Agustín, es la exposición de la muerte como si se tratara de una instalación locativa de las salas de arte contemporáneo, donde el espectador interactúa con la obra cambiando su significado, usándolo según le parezca, cambiando sus sentidos.

En esta heterotopía funeraria, el desplazamiento de las estatuarias hace que se fragmente el sentido ritual y ceremonial de la muerte, propagando la profanación. Codazzi al mencionar varias estatuas entre ellas las del dios sol, dice que " trescientos metros al oriente de estos adoratorios y en una sábana limpia, se encontraron como en fila las esculturas que en la lámina dicha y la siguiente llevan los números 26, 27, 28, 29, 30, y 31, que por el adorno semicircular de las cabezas y la disposición en que están, parecen señalar el cementerio de los sacerdotes, o tal vez el lugar de sus juntas para conferir la última enseñanza y el precio de la iniciación a los neófitos” (1856, p. 426) (Ver Imagen 9).

Quizá aquel "dios sol” (Foto 16) precedía un cementerio a su alrededor o a sus pies, un cementerio no de caciques, ni de hombres, ni de mujeres, ni de niños, sino de sacerdotes, un cementerio de los encargados espirituales. Pero ese lugar ha sido movido, cambiado y profanado por la bandera del conocimiento científico, sin tener el conocimiento de la vida y de la muerte en tanto seres universales, de una comunidad entera y un mundo que le pertenece a la historia de toda una nación. En esta heterotopía se evidencia la ruptura con nuestros antepasados y con el culto a los ancestros, cuya raíz nutricia de un pueblo y una cultura, ha sido quebrantada, casi que podría decir cercenada.

El ritual funerario que quizá existió, nos lleva necesariamente a preguntarnos por el sentido de la muerte, por cuál podría ser el significado de la muerte para este pueblo escultor. Esta experiencia se mezcla con la idea de trascendencia o la vida después de la muerte. Quizás, un viaje hacia el fondo de la tierra, un ir al submundo, a las profundidades a los subterráneos, o quizá un permanecer en la tierra con lo vivos pero en otro estado, quizá la muerte hace parte de un ciclo de la vida y del cosmos, tal vez una transición de una vida a otra. 
Tal vez, el sentido que se habla en la escultórica, tenga que ver con algo que decía Preuss ante sus excavaciones en San Agustín: "los indios de remotísimas edades se iniciaban en los secretos de lo trascendental”, y quizá lo trascendental es el motor de la construcción de tumbas, sarcófagos, estatuas, guardianes, hombres-jaguares, alter egos, estatuas de la fertilidad, trascendencia de un mundo vital, que lleva a las esferas de lo ultramundano un sentido de vida propio y sagrado, que era el horizonte a toda una comunidad.

En definitiva la trascendencia de un pueblo hecho escultura y conservado en piedra. Quizá la vida estaba más ligada con lo trascendental que la muerte misma y quizá la muerte sea la realización real de la trascendencia hecha eternidad. La trascendencia como idea, nos lleva a pensar en un lugar sin forma, sin tiempo y sin lugar, pero en los sarcófagos, dólmenes y tumbas se respira una trascendencia aquí, en un más acá. Veo una trascendencia que no se ha ido a otro lugar sino que permanece en los montículos. La heterotopía funeraria expresa la trascendencia en el tiempo, en el recuerdo de un pueblo desconocido.

En este instante recuerdo una frase de Da Vinci, que parafraseando decía que en la escultura si el objeto es en mármol, muestra trascendencia, (por tradición romana) si es en roca, muestra fortaleza, por la perennidad del material, pero si es en arcilla es sinónimo de pobreza ya que es irrelevante y moderado. Es posible afirmar que en San Agustín existía esa fortaleza en el espíritu de un pueblo que develaba no solo en la vida sino en la muerte, la idea de permanecer en la historia y no morir nunca, sobrevivir en los tiempos.

En este sentido los muertos y sus "espíritus" aún existen. Hay una escultura de la muerte hecha vida, un lugar donde habitan sus muertos y están con nosotros mostrándonos. Así como también lo demuestran las esculturas que tienen por labor cuidar tumbas, seguramente es porque hay algo muy preciado dentro de ellas que posiblemente esté en peligro, podría decirse mejor, solo se cuida algo que por preciado está en peligro de ser perdido.

Los guardianes de los dólmenes, abundantes en las tumbas, guardan a alguien preciado, cuyo valor debe ser protegido y defendido. Pero los guardianes fieles permanecen aún fijos 
a su tumba, unidos de manera esencial a su muerto y observando que nada le afecte a su encomendado. Ellos están unidos a su tumba no por obligación, sino como sacrificio y deber al protegido hasta después de su muerte.

Hoy pienso que tal vez "los guardianes de tumbas" fueron preparados y lo siguen estando para algo más. Cuidan sus tumbas por algún sentido transmundano que se encuentra en ese lugar - otro de la muerte. Quizá el sentido de sus vidas estaba en ser guardianes y testigos de la muerte del sepultado, de pronto al estar enterrados con ellos cobraba sentido toda su existencia mortal y terrena (rangos, clan, familia, códigos de honor) en fin, como había afirmado Codazzi, son los "centinelas de la eternidad". Pero no se puede afirmar que había una creencia generalizada de la muerte como eternidad, o como trasmigración o mutación.

Lo claro es que la celebración de los muertos es algo que universalmente todo pueblo y comunidad realiza como parte de un ciclo natural. Vivir y morir. Nacer y perecer. Como el nacimiento, la muerte es un acontecimiento del que un grupo de personas es testigo y comparte porque hace parte de su propia existencia y su estar natural en el mundo. Y con San Agustín como con todo arte primitivo, es necesario como dijo Preuss: "iniciar una investigación de la universalización de esta cultura". (1974, p. 122)

En tanto universales, como humanos, construimos ciudades utópicas o heterópicas, arquitecturas de la germinación y arquitecturas fúnebres "no hay sociedad humana que no construya heterotopías, es una constante de todo grupo, si bien no es posible encontrar una sola forma de carácter universal, se proliferan, se expanden bajo expresiones y figuras disímiles" (García, 2006, p. 16).

Creamos alrededor de la vida y de la muerte algún producto espiritual para sentirnos vinculados con nuestra mundaneidad. Para recordarnos vivientes y perecederos, en definitiva para sentirnos parte del mundo. De allí el sentido del cementerio como ese lugar otro, que con sentido religioso o no, con trascendencia o no, permite vincularnos con la existencia humana en tanto mortales que somos. Y en San Agustín presenciamos ese lugar totalmente heterogéneo que nos genera la certidumbre de la muerte. De allí, quizá la sensación que tuvo Konrad Theodor Preuss hacia 1913 "como perdido en un callejón sin 
salida, se siente como en los confines del mundo" (Sánchez, 2011, p.31). Sintiéndonos en el límite de un mundo desconocido y a la vez tan conocido.

Desde ese otro mundo conocido que es nuestro mundo-entorno, vemos la heterotopía funeraria de San Agustín como una exposición de la muerte que nos lleva por un lado al juego del enigma ancestral y que nos cuestiona sobre cómo ver nuestro mundo con los ojos de los monumentos funerarios, porque encuentro que también hemos profanado y convertido en corredores turísticos la celebración de la muerte de otros antepasados más cercanos en nuestra historia.

Es el caso del cementerio Central de Bogotá o el bello cementerio blanco de Mompox que brilla por su cuidado y hermosura, mucho más que las casas y hoteles. Lugares a los que se les toma fotos, se les hace inscripciones y en cuyas lajas en mármol o cerámica se sientan las personas a conversar o a besarse. También los gatos que saltan de tumba en tumba tienen su espacio de diversión. La muerte de los antepasados, primitivos o no, no tiene un valor sacro para nosotros. Y con "nosotros" hablo de todo sujeto que siendo parte de la humanidad en general no se identifica esencialmente, es decir, no se apropia de su propia historia.

\subsection{La heterotopía del turismo cultural}

Dado que la heterotopía funeraria de San Agustín ha cambiado para los ojos de los visitantes actuales, se ha convertido en otra heterotopía moderna, un lugar artificial donde se formulan nuevas reglas que solo aplican en ese lugar más allá de la noción de propio, ancestro, antepasado y primitivo. Más allá de la idea de arte, reliquia, patrimonio, es claro que los referentes para ver a San Agustín han sido recreados por el turismo cultural que fomentan el espectáculo y distracción.

La escultura agustiniana es un lugar otro, como utopía de la germinación y como heterotopía funeraria. Pero también se ha reconfigurado ella misma como una heterotopía del turismo cultural, "en el transcurso de su historia, una sociedad puede hacer que una heterotopía que existe y que no ha dejado de existir funcione de una manera muy diferente, 
en efecto cada heterotopía tiene un funcionamiento preciso y determinado en el interior de la sociedad, y la misma heterotopía puede, según la sincronía de la cultura en la que se encuentra tener un funcionamiento u otro" (Foucault, 1999, p. 436).

Es fácil recordar aquello que suele dejarse de lado en una investigación y son las impresiones que la gente tiene sobre San Agustín y aunque parezca anecdótico, contienen la esencia de la estatuaria para el espectador actual. En el primer recorrido por el Parque Arqueológico, llegando a la mesita B, un grupo de turistas de pantalón corto, sombreros zafaris y playeras, escuchaban un relato mítico y supersticioso de los guías que hablaban de buenas energías, descargas espirituales y conexión cósmica, ante esto mi rostro hacía gestos escépticos, pero los visitantes prestaban mucho más interés que el que tenían sobre los datos arqueológicos de cada estatua. Mientras se cambien los términos y se acomoden a las exigencias del mercado, el interés en la escultórica aumentaría.

Aquí, lo que se evidencia es que ante la utopía de la germinación de un pueblo sagrado que tenía ritos y cultos, se toma como supuesto verdadero que es un lugar extraño y enigmático, idea que se repite en los cronistas, investigadores y visitantes de hoy. Pero a su vez se ha re-creado un mundo totalmente nuevo, un lugar impregnado de "energías", un lugar de meditación para el recogimiento y encuentro con el "yo interior" que tiene escenario en el Alto de los ídolos o en el Alto del Lavapatas, un lugar de dioses y chamanes que antaño, tenían algún poder mágico y que en la creencia actual parece seguir latente en la piedra que al ser tocada, quizá nos traslade, mejorando nuestra calidad de vida o absorbiendo nuestros problemas cotidianos.

El observador de hoy busca el espectáculo, la exhibición extraordinaria que permita que los visitantes tengan vivencias místicas y de forma inmediata. No quieren la historia de arqueólogos, periodos históricos o teorías e hipótesis sociológicas. Buscan una diversión o distracción que los saque de su cotidianidad y les ofrezca una experiencia otra. San Agustín está adecuando su entono escultórico para suplir esas necesidades.

Leo un artículo sobre las "measurements of orientations in the monuments of San Agustin culture in Colombia" de 1998, desarrollado por el grupo arqueo-astronómico italiano 
calion, donde se afirma según los estudios, que la mayoría de las estatuarias y tumbas están orientadas hacia el norte o noroccidente, mirando hacia la estrella polar del norte, es decir que en San Agustín hay una conexión, medidas astronómicas y celestes desarrolladas en esta civilización pre-hispánica.

Pero aunque siguieran existiendo estas relaciones con los astros, estos ya no pueden conectarse con las esculturas porque su lugar originario ha sido derribado; en cambio, se habla de nuevas vivencias cósmicas para el turista que necesite un viaje astral, intramundano o chamánico, muy relacionado con la magia y el esoterismo de la nueva era, que permite la meditación y el apego a la naturaleza para limpiar los Karmas.

Mientras algunos ven la escultórica agustiniana como un lugar energético, otros lo ven como parte de un plan vacacional en familia. Un lugar de recreación turística, ir al parque de San Agustín, como quien va algún parque nacional natural del país. A ese parque se va a descansar, relajarse y jugar. De allí, que los guías informales crean rutas y circuitos, se aprenden las mismas líneas de diálogo, hacen las mismas paradas; unas para ver las esculturas, otras para ver los trapiches, en unos puntos, ver las tumbas, pero también en otros, comprar panela y guarapo, comer en algún restaurante campestre.

En el Parque Arqueológico, el plan es caminar por el sendero señalado, el camino original se ha dejado a un lado y pocos lo perciben. El camino que se transita ha sido creado turísticamente para el visitante. Frente al Lavapatas, tomarse un café, un glaceado o una aromática de frutas. Algunos que visitan la región sin guías, no se molestan en visitar unas "piedras", van en su moto o automóvil a contemplar simple y llanamente el paisaje. Ir a ver el salto del Bordones y el de Mortiño es una obligación y viendo de lejos el agua que cae y asomándose al precipicio que hipnotiza, jugar con la pelota y hacer una pausa, sería lo ideal.

Los lugares sagrados de vida y muerte se han convertido en lugares turísticos y ningún feligrés los visita. Solo hay fieles al turismo. Es como la procesión de los creyentes que suben a Monserrate esperando algo allá arriba: una cena en el bello restaurante, una gaseosa fría, una botella de chirrinchi o una foto de la panorámica de la ciudad. Así como 
cuando se asciende a los Altos de las Piedras, de los Ídolos y del Lavapatas, esperando una buena sombra, un resguardo, un fresco o una larga pausa.

Para los visitantes "verdes" está un san Agustín que se conoce en forma de caminata ecológica, conocida actualmente con el nombre de eco-turismo. En busca de los caminos menos transitados, entre los campos de café y de plátano, monte, bosque, ese verde, que también llama, seduce. Mucha vegetación, pocas flores, montañas y abismos, vista desde donde se ve a lo lejos correr riachuelos, como el Mazamorras, el Naranjo y el Granadillos, quebradas como el Tablón, Quinchaná y Sombrerillos.

Para un viaje paisajístico San Agustín es otra heterotopía turística, en donde las historias alrededor del río Magdalena son el centro de atracción. El sentido sagrado de aquel valle del Magdalena que tenía, ha sido superpuesto por otro no menos importante que aún persiste en la memoria de los pueblos a modo de mitos y leyendas.

Recuerdo por ejemplo el 8 de julio del 2011, cuando caminé por primera vez hasta el famoso estrecho, nombre que le da la anchura de 3 metros por el que el río Magdalena pasa con una serie de anécdotas populares, como la que cuenta cómo las personas si cruzan saltando el estrecho, de una cordillera a la otra no vuelven a pasar, porque caen en el río y no se encontrarán sus cuerpos, a menos de que tengan una soga.

Las historias se alimentan de posibles turistas ahogados y desaparecidos, en ese lugar mágico para unos, que aun con un significado mítico es recordado y contado en la memoria de las gentes. En aquel lugar, no puede faltar la semilla de achote que el guía desprende del mismo árbol, tampoco se despide del lugar sin haber caminado por las piedras volcánicas que aún se encuentran cuando se está en verano llevando un ejemplar en el bolsillo.

Las palabras primitivo, ancestral, antiguo, originario, se ha convertido en un producto, un producto comercial del turismo. Este fenómeno del capital turístico ha tomado el patrimonio de los pueblos para exportarlos en forma de artículos que consumen coleccionistas de todo el mundo. Lo otro, es que al comercializarse este producto patrimonial, se populariza la cultura de una comunidad, de tal manera que hay un consumo 
de la historia pasada de los pueblos. Desde esta perspectiva el patrimonio se revive en tanto que es rentable y útil, lo que se ha denominado como "la industria del arte".

Esta heterotopía del turismo cultural del patrimonio, desplaza y crea nuevos sentidos para las obras de un pueblo, para adecuarlos a las exposiciones de museos internacionales, cada una con una nueva idea. Llega a mi memoria el título "Más allá de El Dorado, poder y oro en la antigua Colombia", conocida exposición que se realizó en el Museo Británico de Londres en el 2013, y que fue un éxito. Donde además de 300 piezas en Oro de la colección del Museo del Oro en Bogotá, habían otras de las colecciones privadas y exclusivas del museo.

Y allí en aquel lugar otro, las obras escultóricas agustinianas fueron vistas, "Other fascinating objects will include an exceptional painted Muisca textile and one of the few San Agustín stone sculptures held outside Colombia. Those, together with spectacular large scale gold masks and other materials were part of the objects that accompanied funerary rituals in ancient Colombia." 35

La idea mítico-religiosa y ritual de las culturas ancestrales amerindias, sigue impactando los oídos del mundo, en especial cuando se habla de oro. También la exposición en Bogotá El silencio de los ídolos. Una evocación de la estatuaria agustiniana, fue la idea de conmemorar los 100 años del descubrimiento por parte del célebre etnólogo alemán Konrad Theodor Preuss, quien realizó importantes excavaciones. Pareciera que la única forma de conocer y dar a conocer "lo propio" es a costa de su desplazamiento, su deterioro, su profanación, a través del turismo cultural que crea y recrea los espacios del patrimonio, sin ningún interés por conservar y preservar la historia.

La heterotopía del turismo cultural evidencia que la esencia de un pueblo no se halla en el interior de unas esculturas incognoscibles, sino en el mundo de quienes las miran. Cuya experiencia humana no ha reflexionado sobre el sentido de su existencia, de su estar, de su

\footnotetext{
${ }^{35}$ Tomado de la presentación oficial de la exposición. http://www.britishmuseum.org
} 
origen y tampoco el de su telos, y ello refleja no el silencio de los ídolos, o enmudecimiento del arte sino el silencio frente a la memoria y la historia de una nación. No es la pérdida del sentido originario de un pueblo desaparecido sino también la carencia de sentido originario de lo que somos como pueblo.

El dios sol y las demás estatuas son solo epifanía de algo no revelado, oculto e invisible, cuestionan mi propia condición como perteneciente a un territorio que cohabito con esta estatua, cuyo sentido solo halla suelo en el desplazamiento, suplantación de nombres, adopción de discursos como verdaderos e incrustaciones de materiales externos en nuestros órganos vitales.

Esa historia natural de lo sagrado no la vemos como natural, sino como la utopía de un pasado mejor, falo germinador que queremos castrar, ocultar o enmascarar, que nos da vergüenza y preferimos tapar con cemento importado, sin un vínculo con nuestros ancestros mostrando el olvido y la carencia de la memoria histórica. Ello me lleva a reflexionar que el estupor frente a la obra de arte agustiniano, de su espacio, es que como esas piedras, no tenemos la certeza de un origen auténtico y originario.

Konrad Theodor Preuss desde la etnología, plantea que al descubrir San Agustín vio "un arte extraño y primitivo, inaccesible para nosotros occidentales" (Sánchez, 2011, p.14). Pero sí es posible vernos en la obra como en el espejo. Somos el reflejo de esas esculturas sin origen, somos las tumbas abiertas sin cuerpos y sin ofrendas. El uno es el reflejo del otro. La pérdida de sentido, autenticidad y origen en ambos está derrocado. Ante la pregunta del origen de la obra de arte agustiniano, surge la cuestión por el origen del espectador que la interpela.

Así, también esa ausencia y carencia nos lleva a crear heterotopías y utopías porque nuestro espacio no se ha configurado como una realidad del mundo. Ello nos duele y hace lamentar, a veces odiar todo aquello que nos lleve a pensar en ese vacío. Viendo más claramente, este falo no puede entenderse en una piedra volcánica sin poseer piel, la piedra ya no es piedra, es mi carne. Aclaro los lentes de mis gafas y caigo en cuenta que es realmente la estatua la que me interpela, poniéndome su piel. Somos esa carne olvidada 
que se ha hecho piedra con el tiempo y una simple estatua espectadora del mundo y no activa en nuestro mundo de la vida.

La escultura refleja una imagen de sí mismo, es un cuerpo, un personaje, un ser que para nuestros ojos colonizadores puede significar magia, demonios, divinidades y cultos extraños; pero la escultura en su sentido universal, es la construcción de un cuerpo que tiene su propia imagen y un sentido dentro de un mundo, "solo concibiendo la imagen del cuerpo podemos situar la idea de nosotros mismos en el exterior" (Read, 1994, p. 50).

La obra de San Agustín es una memoria, un recuerdo oculto en el olvido de un pueblo desaparecido. Su vista misma está ahí ante mis ojos como flashback de otra dimensión de otro tiempo pero en el mismo espacio. Han sido olvidados, nadie les pregunta, ni los miraba verdaderamente. La obra monumental de San Agustín es un lugar de la memoria. Un recuerdo oculto en el olvido de un pueblo desaparecido. Pero que dejó una huella imborrable en sus manifestaciones vivenciales, en sus tumbas, sus montículos, sus ídolos, altares y lugares rituales. Es la escultura de la muerte hecha vida. Es un pueblo que se presenta ante nosotros a través de sus obras que fueron acciones pero hoy son memoria. Su vida está en la manifestación de la muerte que hoy vemos y percibimos como real, con un sentido vivo de sus vidas, sus pensamientos.

No es un mundo silencioso y estéril, no es la muerte sin más de algún pueblo prehispánico que tiene la necesidad de expresarse. Es algo más. Es palabra, habla desde la imagen llenando a la piedra de historia y espíritu como obra viva. San Agustín es memoria hablada a través de la imagen. No es silencio silencioso. No es vacío vaciado de sentido. No es ausencia ausente. No es olvido olvidado. Es un silencio que habla. Es un vacío lleno de sentido. Es una ausencia presente y es un olvido recordado. Esa obra de arte vivo que habla de la vida, de la muerte en la memoria de su palabra hecha escultura. Desenmascarando que no es mera pieza de museo, sino imagen de la memoria de nuestros ancestros.

En general, no hay un interés nacional por esta memoria arqueológica. San Agustín no hace parte de los lugares preferidos del turista colombiano a pesar de ser considerado desde 1995 por la Unesco, como "patrimonio histórico y cultural de la humanidad" y catalogado 
como la tercera maravilla de Colombia después del Santuario de las Lajas y la Catedral de Sal de Zipaquirá. Pero siguen siendo pocos a los que estas "piedras" talladas, esculturas inmensas y tumbas monumentales, significan algo, quizá un descubrimiento, el interés por una cultura olvidada de un pasado remoto del cual buscamos su origen, su sentido de la vida y de la muerte.

Al preguntarme por la esencia de la escultura agustiniana, surge de inmediato la cuestión por la esencia del espectador colombiano, que en el fondo es la pregunta que me hace la estatua del dios sol, ¿Qué eres? ¿Quién eres? La respuesta se hace visible ante la descripción retrospectiva que quiere llegar al origen mismo de mi cultura y de nuestra cultura colombiana, que de la misma manera se le ha impuesto nombres, se le ha quitado sus raíces, se ha suplantado el lugar que posiblemente tenía antaño y del cual solo algunas huellas casi indelebles quedan, una de las cuales es la escultura agustiniana como testigo precolombino.

Todo esta investigación por la esencia de la escultura agustiniana, es también un autoexamen como parte de ese lugar otro que lleva a pensar la escultura como particular, pero también a mí como particular y general, que en tanto universal se encuentra en un fin, una dirección de entender que las culturas primitivas son solo lugares utópicos o heterotópicos de un pueblo que o los reconoce como propios o los desconoce y rechaza. Aquellos que los reconocen como propios serán pueblos auténticos, pero aquellos que no lo hacen llevaran una historia inauténtica.

Hay una disposición para conocernos como seres humanos, una antropología filosófica que puede pensar el hombre mismo a partir de nuevas objetos. San Agustín es un particular a través del cual es posible conocernos como humanos. Pensarnos como seres humanos no desde lo uno o lo mismo sino desde lo otro, en el lugar de lo otro. Cambiando esa mirada de vernos a nosotros mismos y encontrar otros caminos para hacer filosofía, no tomando el hombre como medida de otro hombre, sino cómo a través de obras primitivas podemos encontrar una nueva visión de hombre. Al reconocernos desde la posibilidad de lo otro, nos entendemos como parte de una hombre cultural, natural, que hace parte de nuestro rostro y que enmascaramos continuamente para no estar ni habitar el lugar de nuestra vida. 
Así instauramos una renovación, otra forma de relacionarnos con el mundo de nuestro pasado y con el actual, y esas nuevas relaciones nos llevan a percibir las obras, las cosas, los otros y a nosotros mismos como parte de todo ello. Es como si para sabernos parte de la humanidad, tuviéramos que morir primero, pasar por el derrocamiento, el silencio, el sinsentido. Para luego de vernos en el enmudecimiento, crear y reestablecer un lugar en el cual se desplieguen nuevos horizontes que no lleven a la repetición fatal de lo mismo, sino a coexistir en espacios que son posibles de habitar, crear utopías o heterotopías para vivirlas como reales, en espacios para ese otro hombre, con otros discursos y otro mundo de la vida renovada.

En esa vida cotidiana donde todo es posible, los juegos de las posibilidades se multiplican en la facticidad que nos lleva a una vida radicalmente nueva, con un estilo y un ethos filosófico. La reconstrucción de ese lugar originario a través del lugar otro, nos lleva a esa nueva mirada de nosotros mismos para renombrar y re-significar y dar otro sentido a nuestro estar en el mundo, un estar inacabado de nosotros mismos. A través de la estatuaria como vemos nuestro propio cuerpo y nuestro estar ya que "es necesario que se despierten con mi cuerpo los cuerpos asociados" (Merleau-Ponty, 1995, p. 367) sujetos y cuerpos que finalmente me lleva a un autoconocimiento. 


\section{CONCLUSIONES}

Frente a la pregunta, ¿Cuáles es la esencia de la escultura de San Agustín-Huila? La respuesta es: un no-origen. Esto no como una imposición de la percepción sino como parte de la vivencia fenomenológica que se tiene en ella y con ella, de lo que la obra como escultura me permite ver en retrospectiva hacia su posible origen, y lo que a partir de ella vislumbra en el mundo de la vida donde habita. Lo propio de la escultórica es que no es originaria, y ello no por carencia de una esencia o por ausencia de sentido sino por la imposición de múltiples sentidos que le son impropios y ajenos a su constitución, y por tanto, el sentido originario que en algún momento tuvo, fue derrocado.

Esa esencia: no-origen, se hace visible en el ejemplar "dios sol", en el desplazamiento y modificación espacial que se evidencia en sus fotografías y en las noticias del archivo de su historia; la imposición de nombres que determinan un significado e interpretación sea de índole moralista, religiosa y/o academicistas, mencionados por los exploradores que la han visto y las han reseñado; la definición de los símbolos, a los que se le atañe funciones diversas según la vivencia de cada explorador y sus referentes de mundo; También, ese noorigen se muestra en la destrucción de la obra, sus incrustaciones de oro perdidas, colores y texturas no preservados; y el saqueo de las tumbas que al parecer ese "dios solar" custodiaba, (Cf. Imagen de Codazzi).

De la misma manera y por correlación, esa misma esencia se manifiesta en otras estatuas que han sido movidas de su lugar originario, su sentido destruido y sus riquezas saqueadas, así el "Doble yo", “el Flautista”, "el Obispo", “el Lavapatas”, son llenadas de contenidos "otros", y no corresponden a ningún sentido originario ni auténtico por no provenir de la obra misma, sino de las interpretaciones de los visitantes que las han visto como ajenas, extrañas, misteriosas, místicas, exóticas y oscuras.

Así también, la falta de exactitud en las versiones del desarrollo de la escultórica, las distintas hipótesis de la existencia de ese Pueblo Escultor, su asentamiento y desaparición, dificultan encontrar un origen claro en la historia. A ello se suma el daño y el deterioro que ha sufrido aquellas esculturas, tumbas y sarcófagos que cuentan la historia del saqueo de 
objetos ancestrales y aunque muchas de ellas aún se encuentran perdidas, las que en la actualidad encontramos, se preservan bajo la idea de un turismo cultural, modificando el entorno, recreando situaciones para dar una interpretación en el espectador, en un lugar artificial. Por tanto hay un derrocamiento del sentido originario, y con ello, todo lo que se enuncie como verdad auténtica y originaria es insuficiente.

Así pues, el origen esencial de la escultura de San Agustín es que no tiene origen. El silencio que inicialmente se hizo visible en el ejercicio de la descripción, toma relevancia al ver que se ha derrocado el sentido originario de la escultórica, y por tanto todo lo que pueda postularse como una esencia debe ser, en miras de ese derrocamiento al que nos arroja el no-origen de la obra.

Sin embargo, dado que se ha derribado cualquier posible esencia que afirme el origen de la escultórica, surge la necesidad de declarar o postular una posible esencia, que de un sentido que reconozca el no-origen de la obra. Tomando como punto de partida esa pérdida del sentido originario propongo ver a la escultura agustiniana como un lugar-otro.

La escultura no se entiende como un cuerpo separado del entorno, ella se explaya en el espacio y tiene un lugar que le da sentido a su mundo. Pero dado que ese mundo y ese sentido es ajeno, es un lugar otro, libre de determinaciones fijas, permeable, susceptible de diversas interpretaciones, usada de distintas formas, leída por múltiples ojos. Ese lugar-otro tiene en su constitución ser movible y cambiante en cuanto a su origen y sentido se refiere.

Como "lugar otro", es posible ficcionar e imaginar que la escultura de San Agustín- Huila responde a un sentido universal de vida, expuesto en la germinación de un pueblo, que busca ser fundador de una cultura, de una comunidad primitiva, como un impulso natural que tiene todo pueblo por expresar su visión del mundo. Ello es un u-topía. Ese lugar irreal al que le damos el don de la ensoñación y de crear un mundo armonioso y sagrado, que se percibe en las esculturas que expresan el nacimiento, en el paisaje, en los ríos, en los animales...

La escultura como u-topia vista desde la obra, es un lugar de la germinación de la vida, y vista desde la óptica de la vivencia fenomenológica es la realización de la u-topía de estar en la obra, de habitarla, ser ella misma, tomar el lugar de la experiencia de la carne como si 
ella fuera un otro viviente, viéndome a mí misma como parte de ese lugar utópico donde es posible tener un origen como pueblo, como nación, que germinó en el seno de un lugar donde la vida tiene un carácter sagrado y espiritual.

La escultura agustiniana y el entorno en donde se espacializa como lugar-otro, también tiene la posibilidad de ser una heterotopía, ser un lugar prohibido. Un lugar enigmático. De allí que se declare la heterotopía funeraria. En lo que respecta al sentido de la muerte, que quizá fuese trascendental para aquel pueblo escultor, que dejó sus tumbas, hipogeos y sarcófagos, respondiendo con ellos a una vital y humana idea del perecimiento, que universalmente en todo tiempo ha sido digno de ser expresado. Una heterotopía funeraria que habla de la trascendencia de la vida en el mundo, en una afirmación del estar presente en un aquí, pero a través de la muerte.

Visto desde la vivencia subjetiva, la heterotopía de estar con la obra, y ver desde ella mi mundo circundante, me hace reflexionar sobre el contenido de la muerte como una trascendencia no del más allá de los muertos y la escultura funeraria, sino de la notrascendencia frente algunas arquitecturas fúnebres a las que re-significamos en la heterotopía del turismo cultural.

Como lugar-otro, sea como utopía o como heterotopía, la escultura agustiniana y su entorno, me llevan a pensar en el espectáculo de la muerte y el de la vida, de la que es presa este lugar, dado la heterotopía actual que rige las lógicas del turismo y consumo cultural, que modifican la vivencia de los espectadores y a la vez el sentido que estos van configurando de la escultórica.

Con ello se concluye que todo esta investigación esta acido por el método fenomenológico. En un primer momento constituye la descripción de un ejemplar como "el dios sol" con sus variantes, la tematización de la esencia: no-origen de la obra, la aclaración de esa esencia, y la variación de la esencia con respecto a otros ejemplares. Luego en un segundo momento, la ideación de la esencia no-origen a través de la postulación del no lugar, y con ella todo la idea que le da sustento a la estatuaria.

Todo el método aquí aplicado, no puede olvidar el ver retrospectivo de ese sustento eidético hacia el mí mismo. Hacia el propio yo. Por tanto en el texto también hay una 
relevancia especial de lo que para mí misma ha significado esa esencia, esa ideación, con respecto a un conocimiento de mi mundo circundante y a un autoconocimiento, sin el cual una investigación fenomenológica no tendría validez. De allí que la escultura agustiniana es para mí, una partícipe de ese mundo cultural, un misterio que sigue evocando reflexiones, pensamientos y a pesar de su peculiaridad continúa generando preguntas sobre nuestro pasado. 
ANEXOS
Fotografías e imágenes 
Mapa 1 Ruta arqueolígica san agustin -huila.

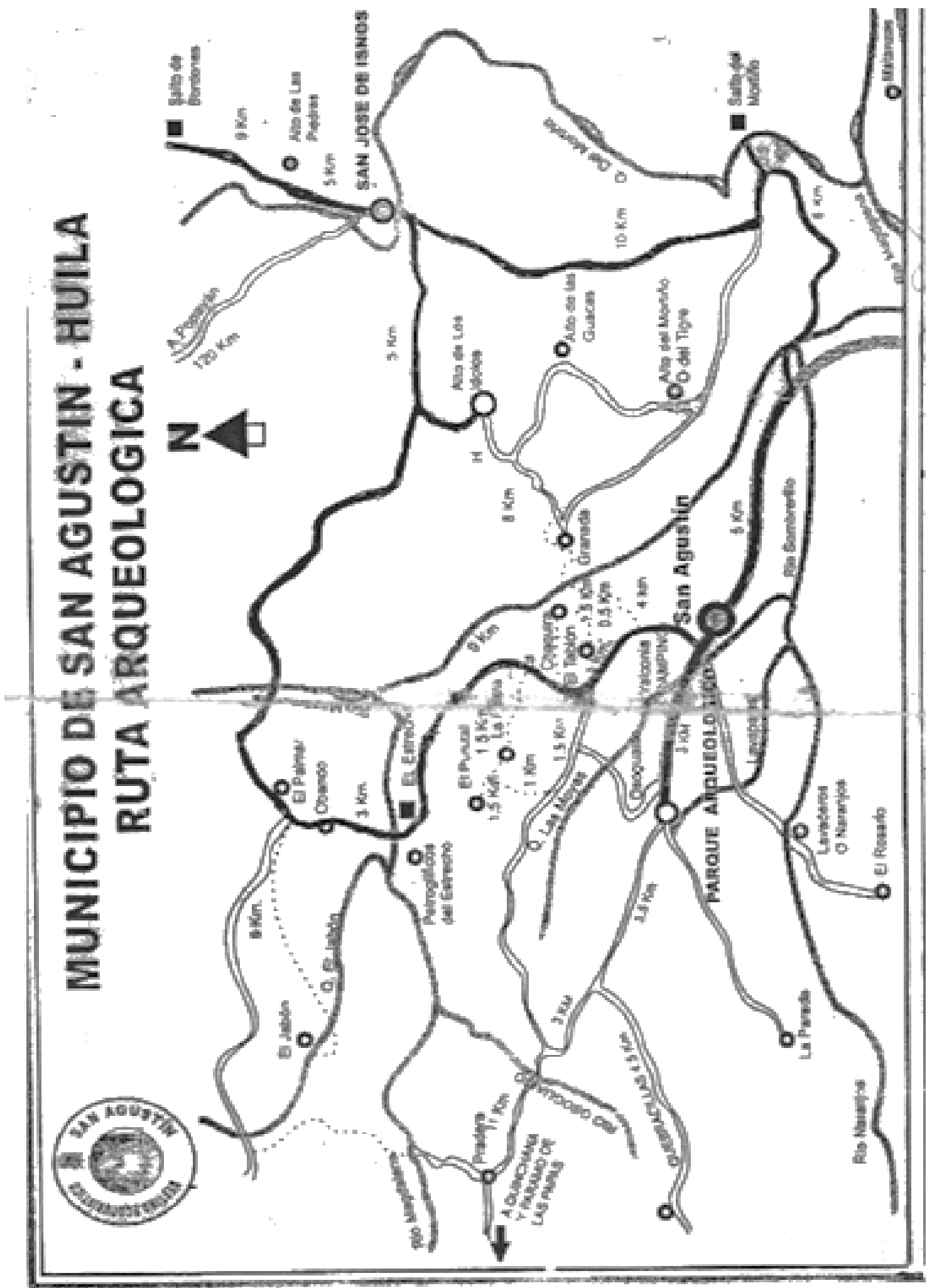


Foto 2. La Máscara.Mesita B del Parque Arqueológico de San agustin. Tomada por Cristina Toro. (2013)

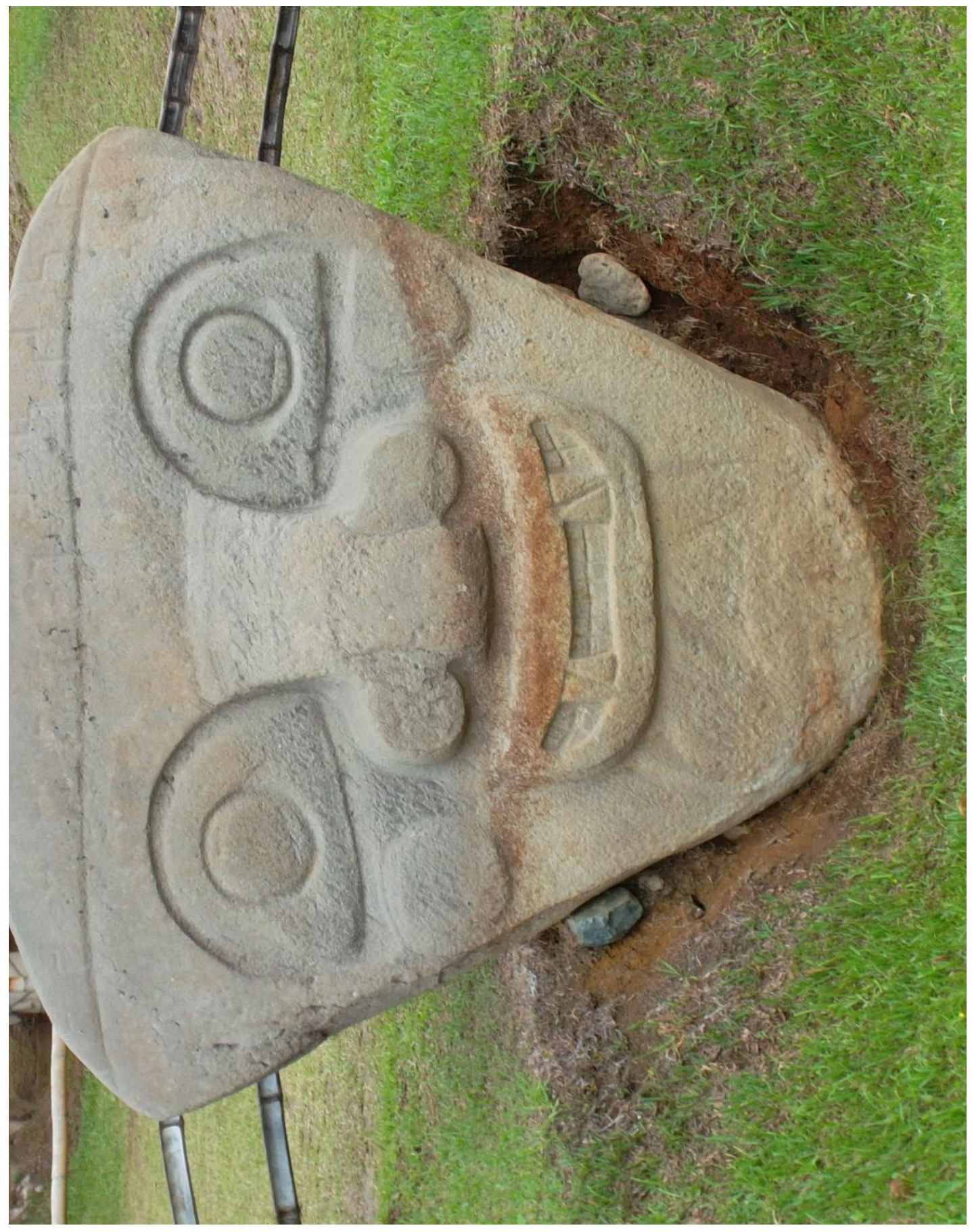


Foto 2. El Águila mordiendo una serpiente. Tomada por Cristina Toro. (2013)

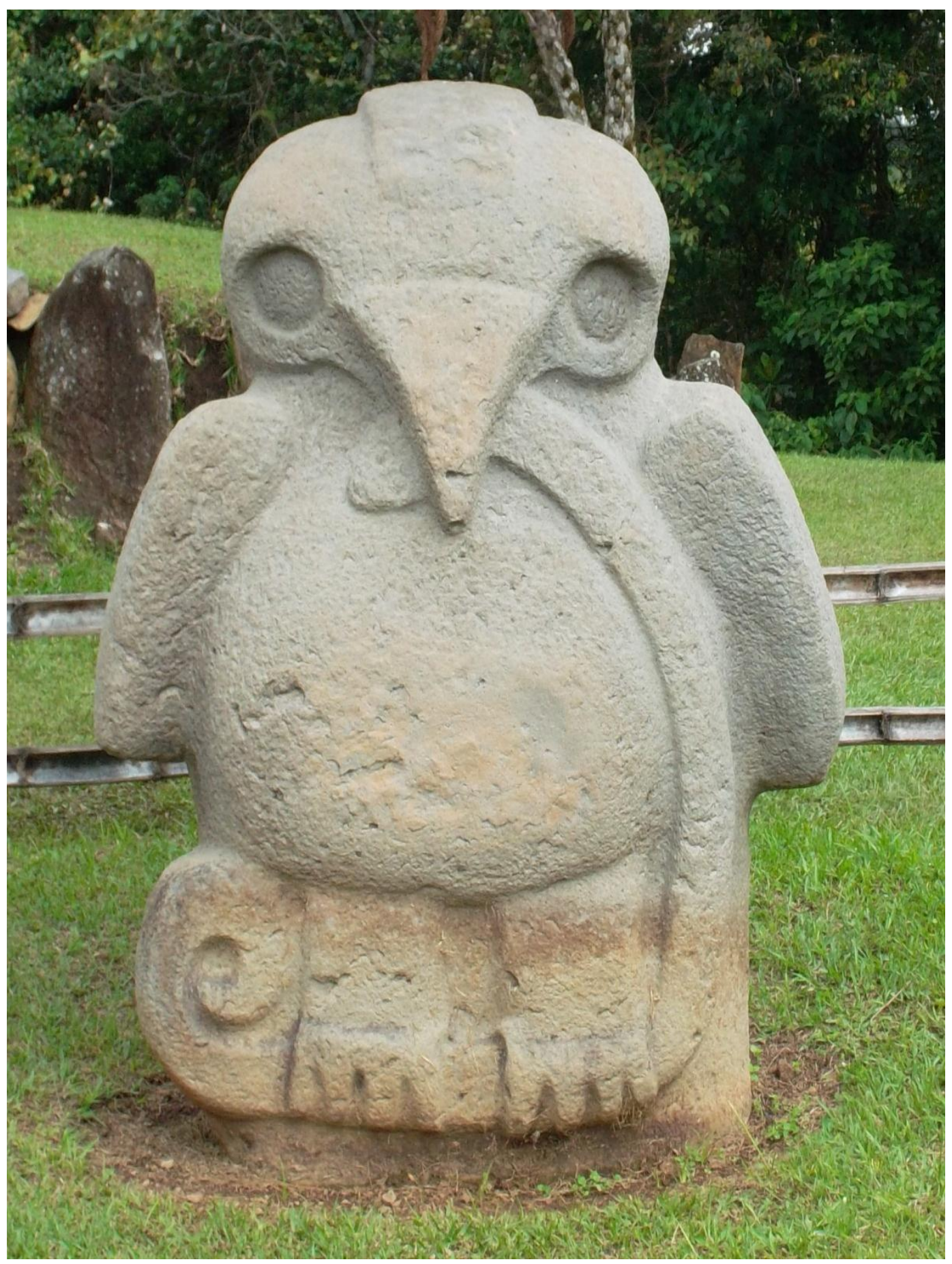


Foto 3. Monticulo Oriental de la Mesita A.Parque arqueológico de San Agustin Huila. Tomada por CristinaToro (2013)

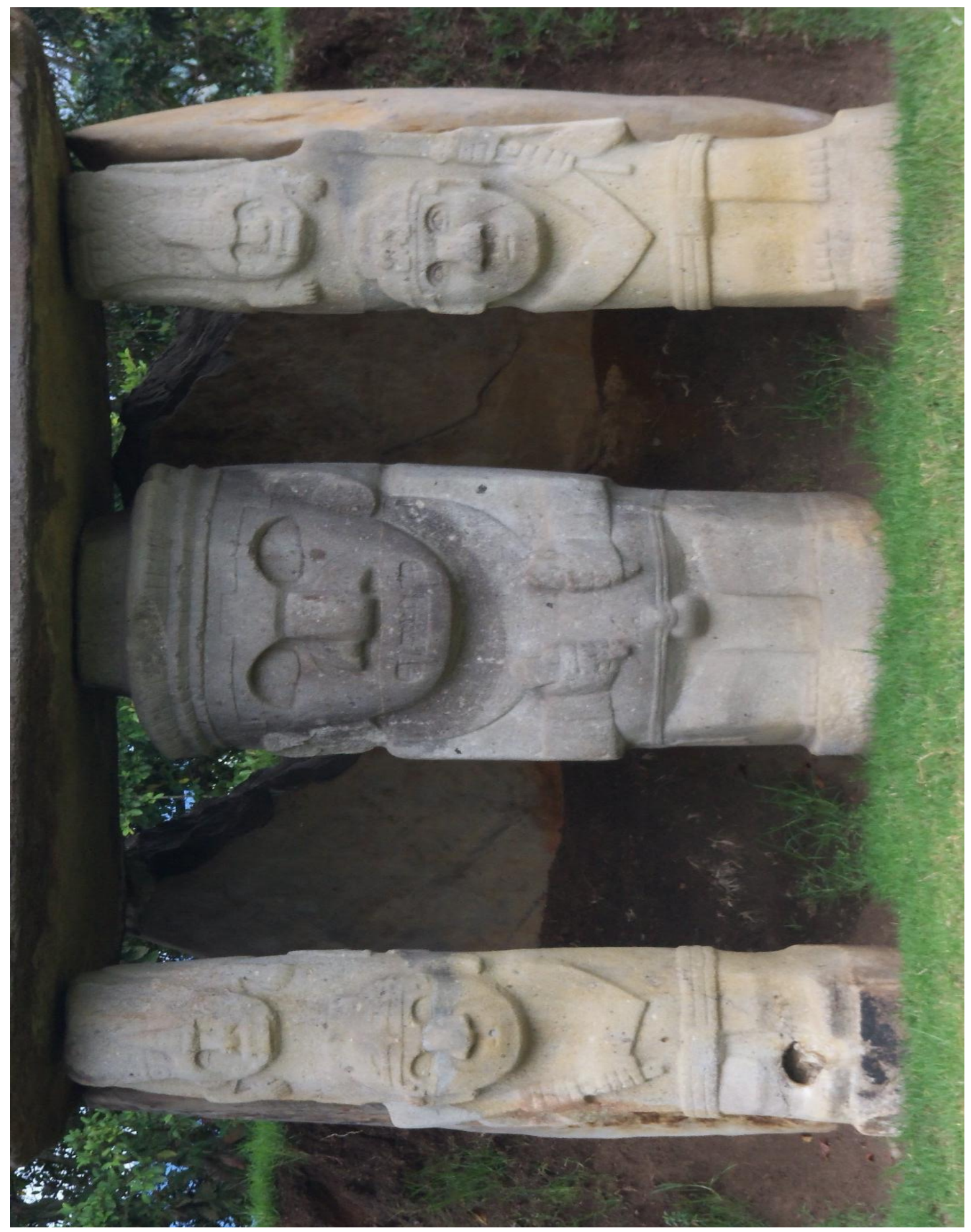


Imagen 1-2 . Original de las estatuas del Montículo Mesita A.

1.Tomado del archivo digital del ICANH. http://www.icanh.gov.co

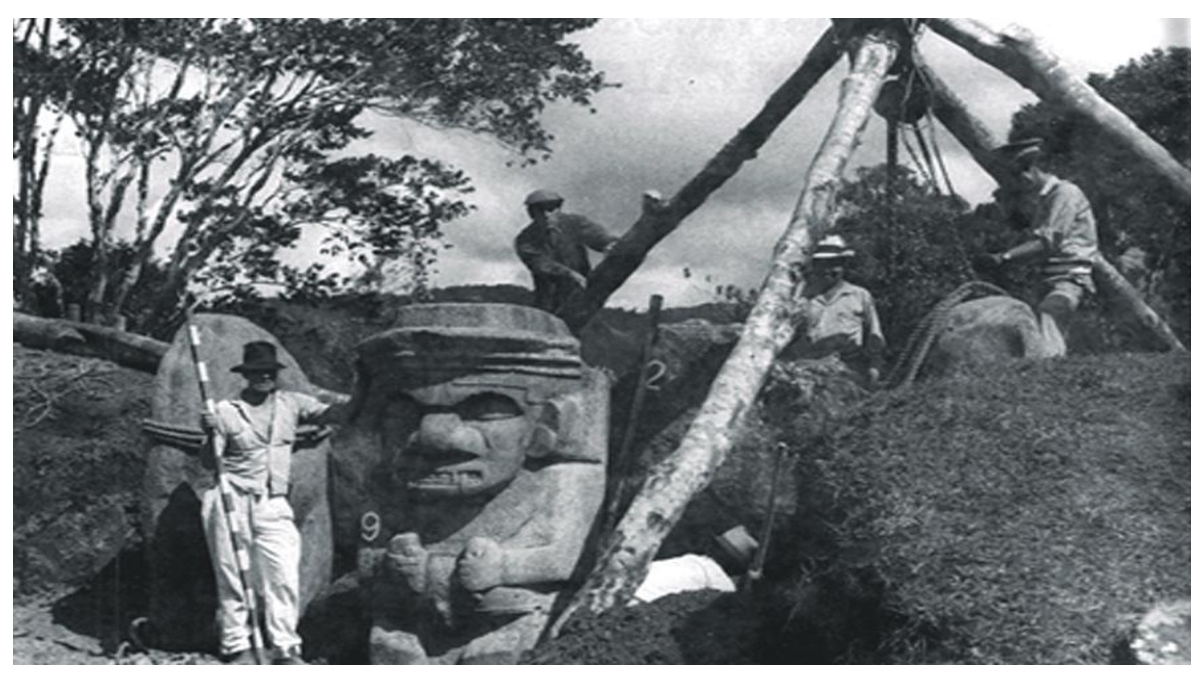

2. Fotografía que aparece en la casa-museo de Juan Freide en el alto de los ídolos

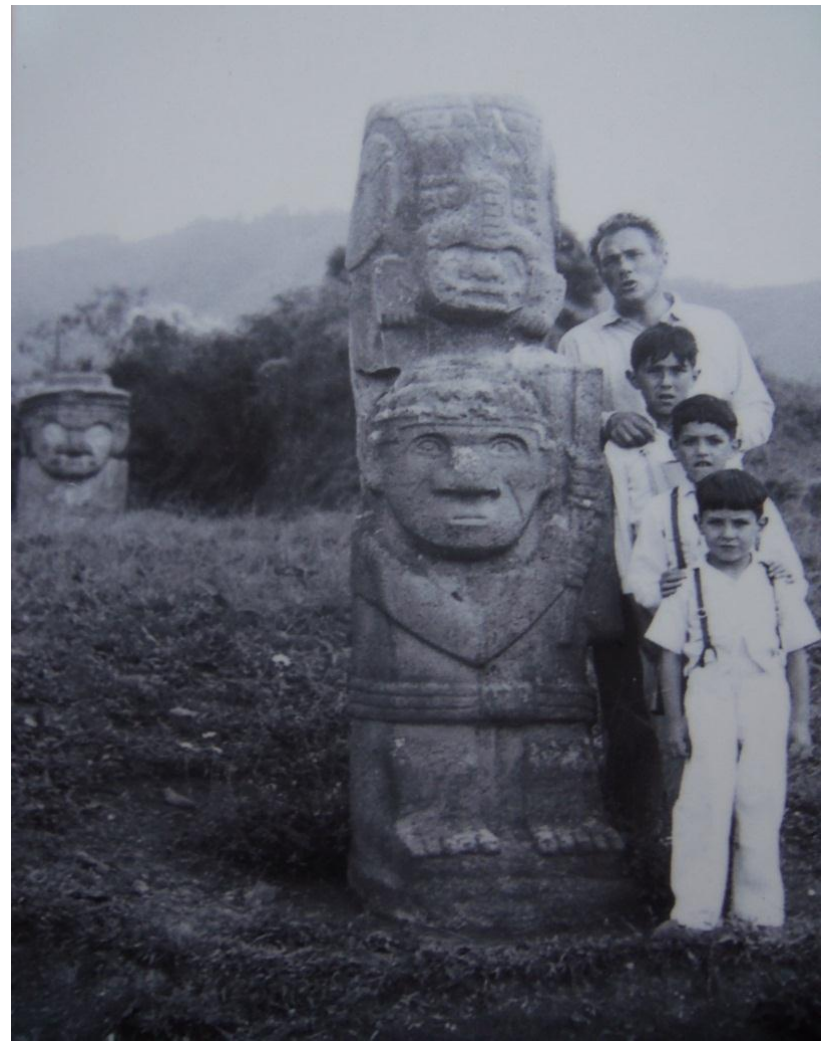


Foto 4 El dios sol en el Bosque de las estatuas, dentro del parque arqueológico de San agustin. Tomado por Cristina Toro (2013)

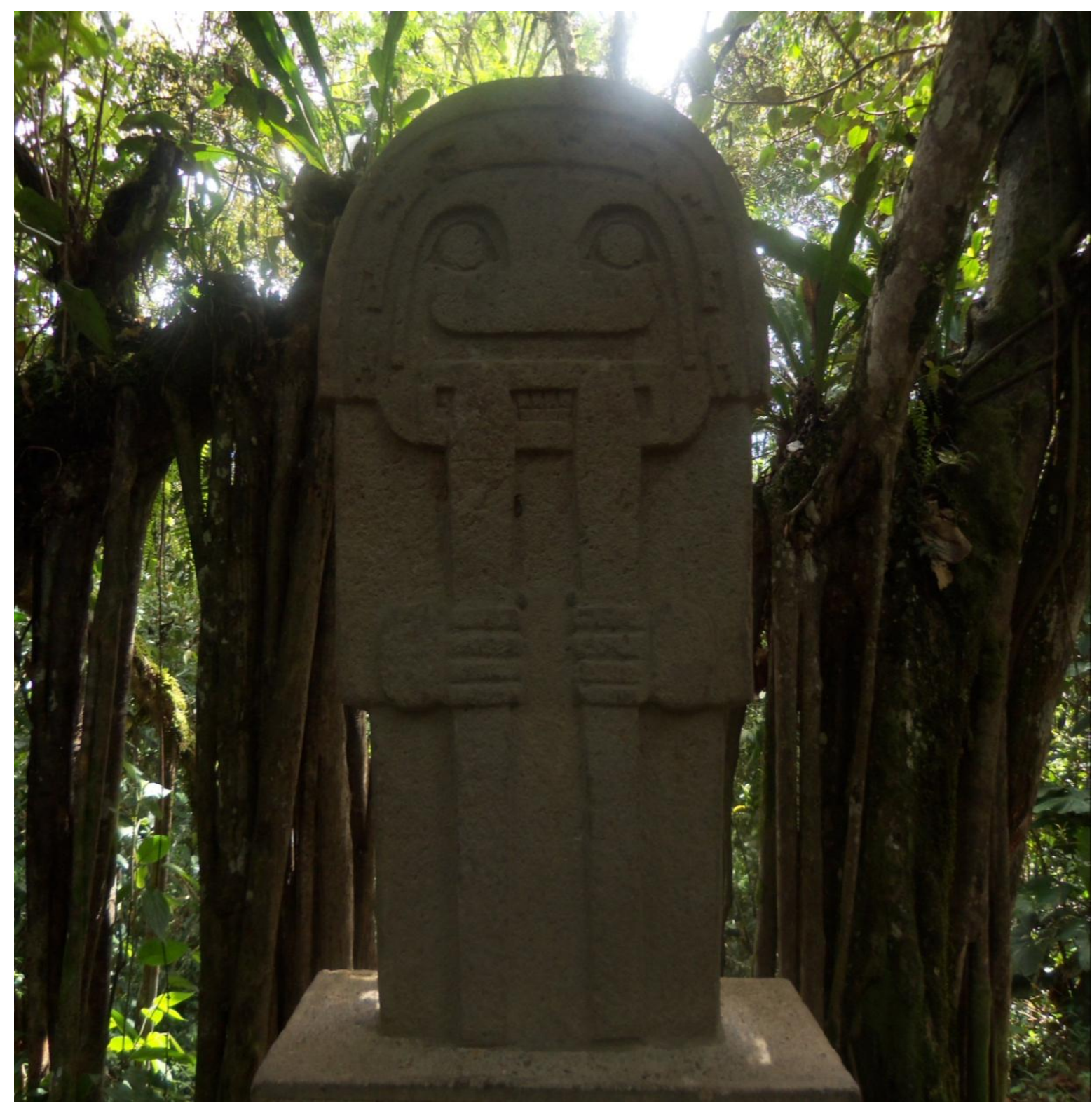


Parte adversa del dios sol. Tomado por Cristina Toro.(2013)

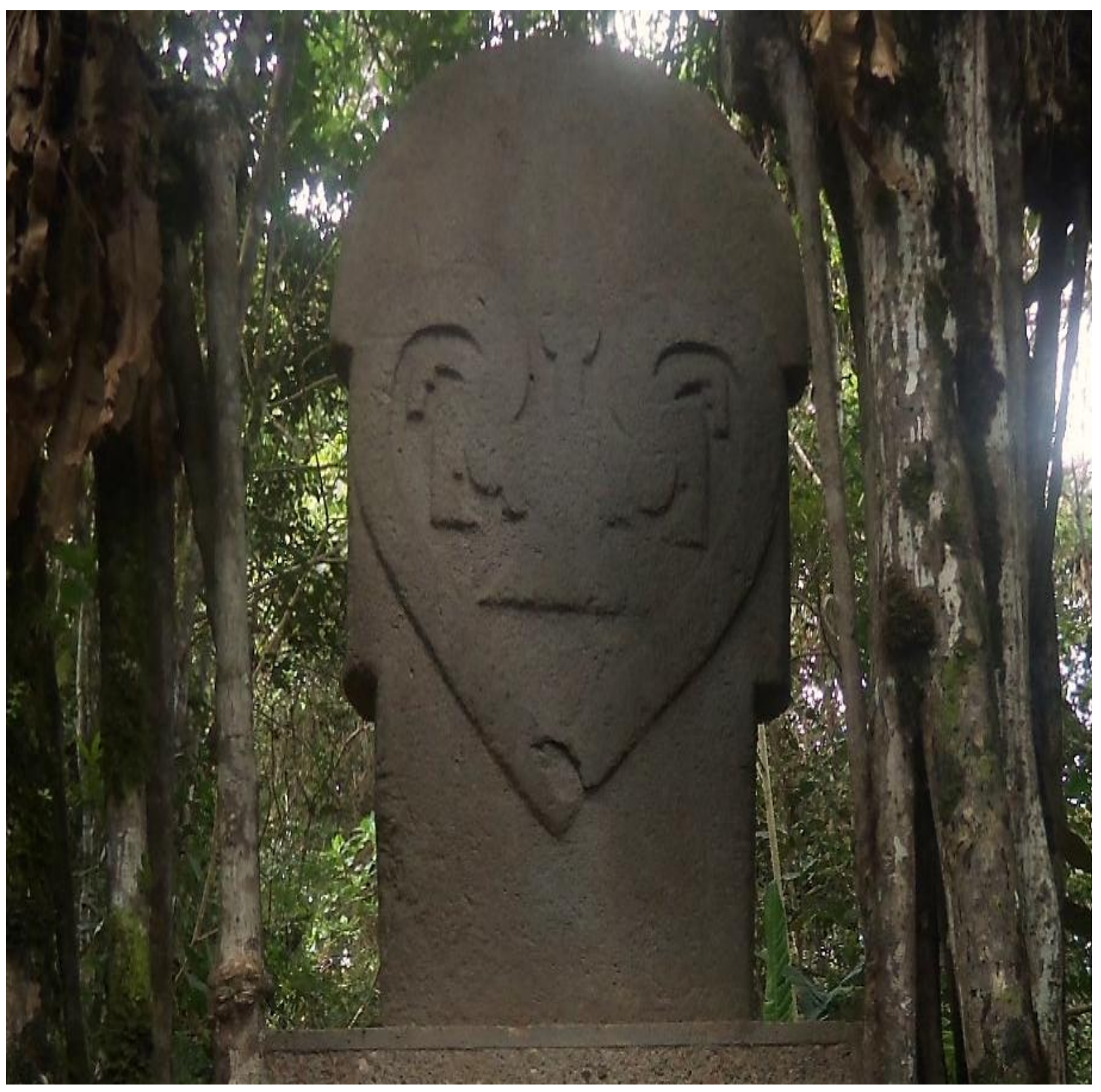


Imagen 3. Original de las estatua dios sol. Tomado de: Perez de Barradas. Se encontraba en la plaza de San agustin.

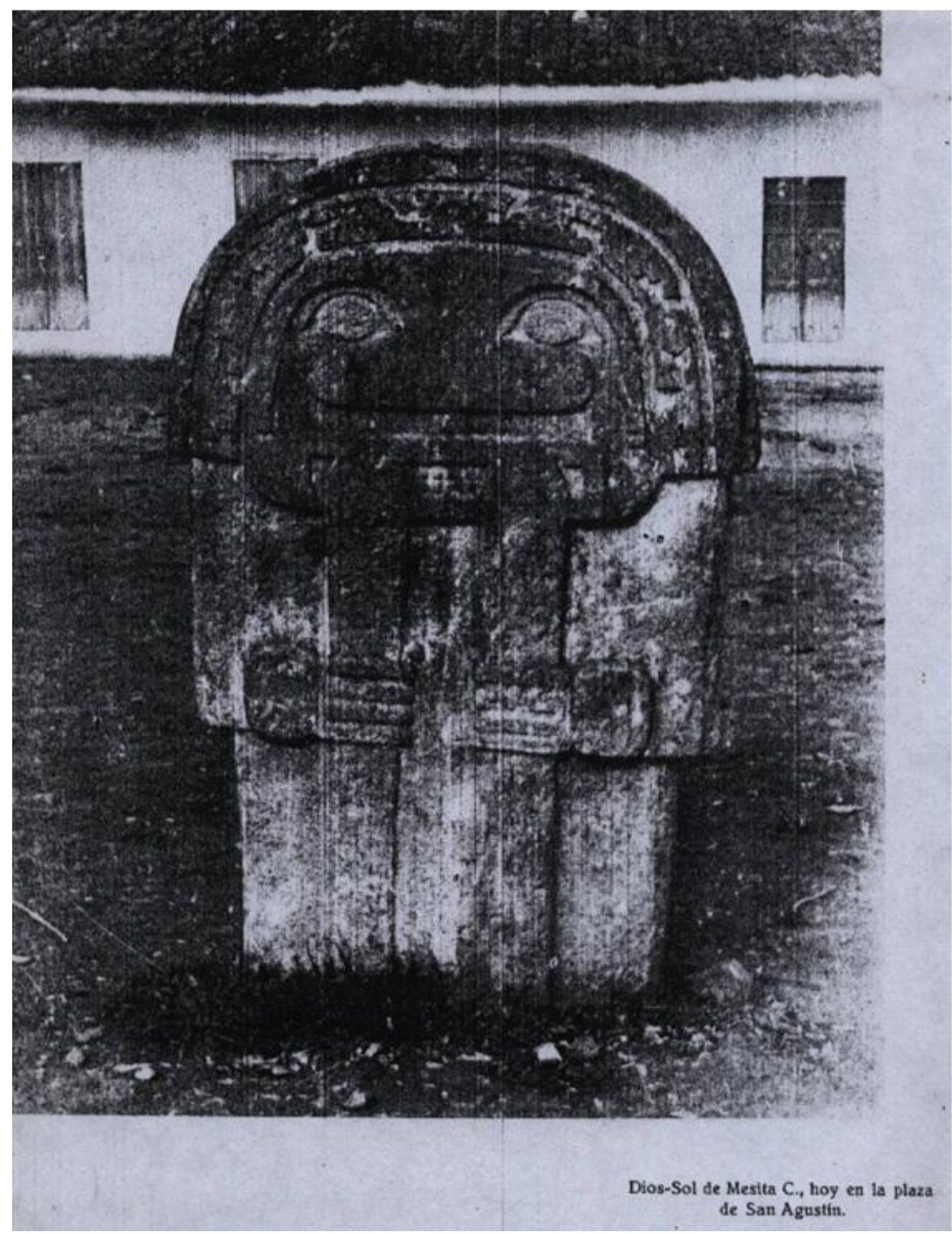


Imagen 4.Dios sol en la plza de san agustin. Fotografia de Perez de Barradas.

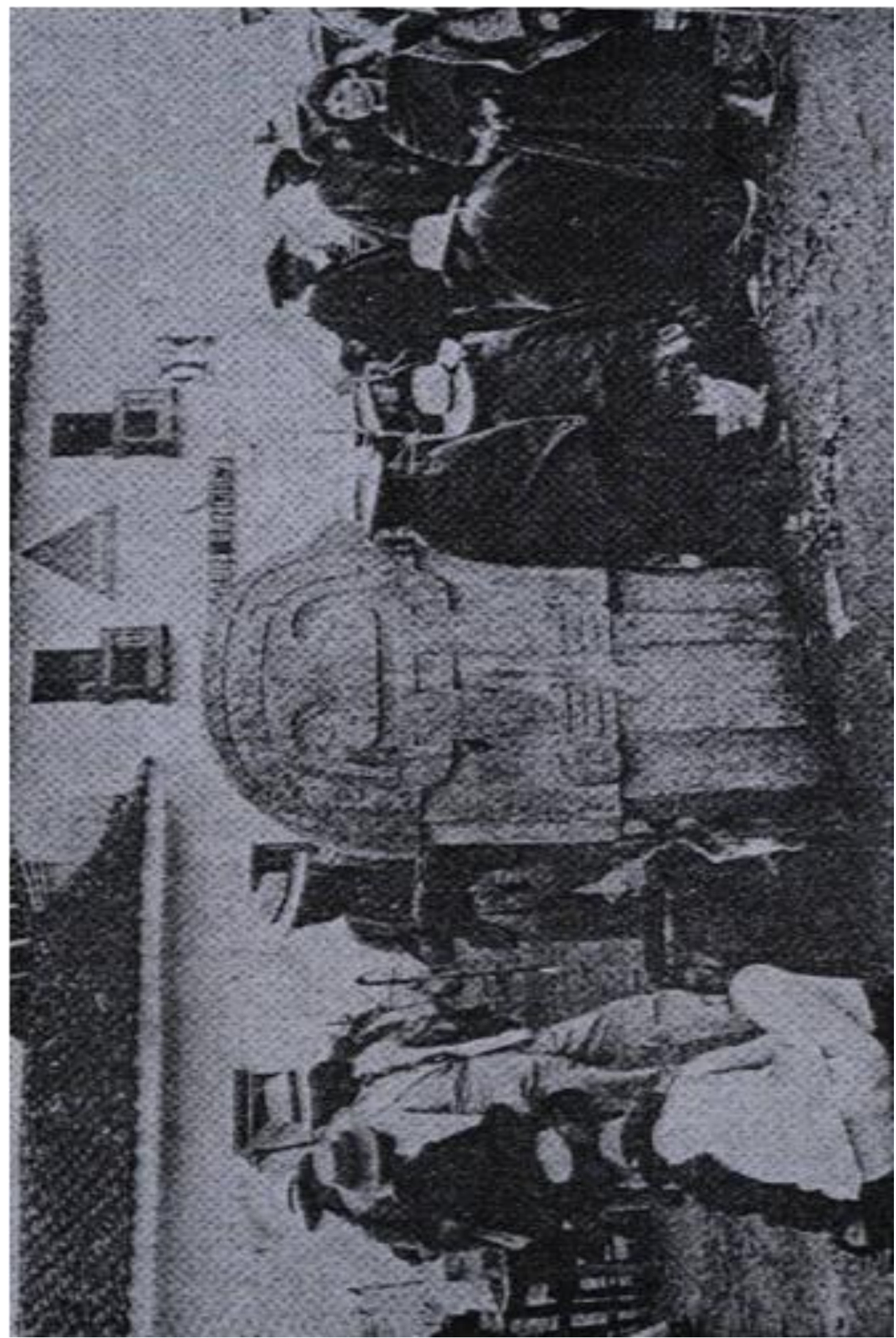


Imagen 5. Dibujo del "dios sol” por David Delemback.

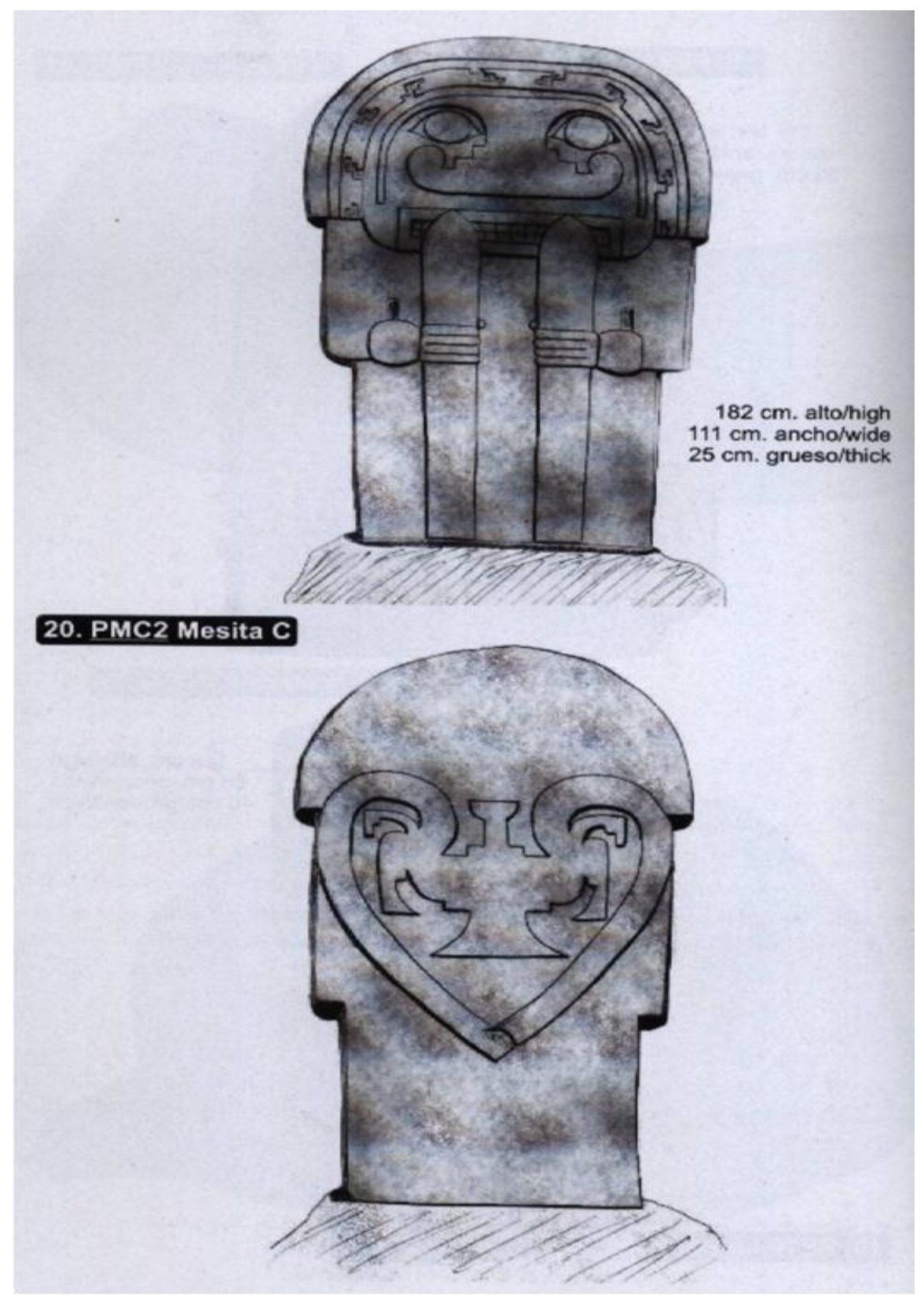


Foto 5. La fuente del lavapatas en la actualidad (año 2013)

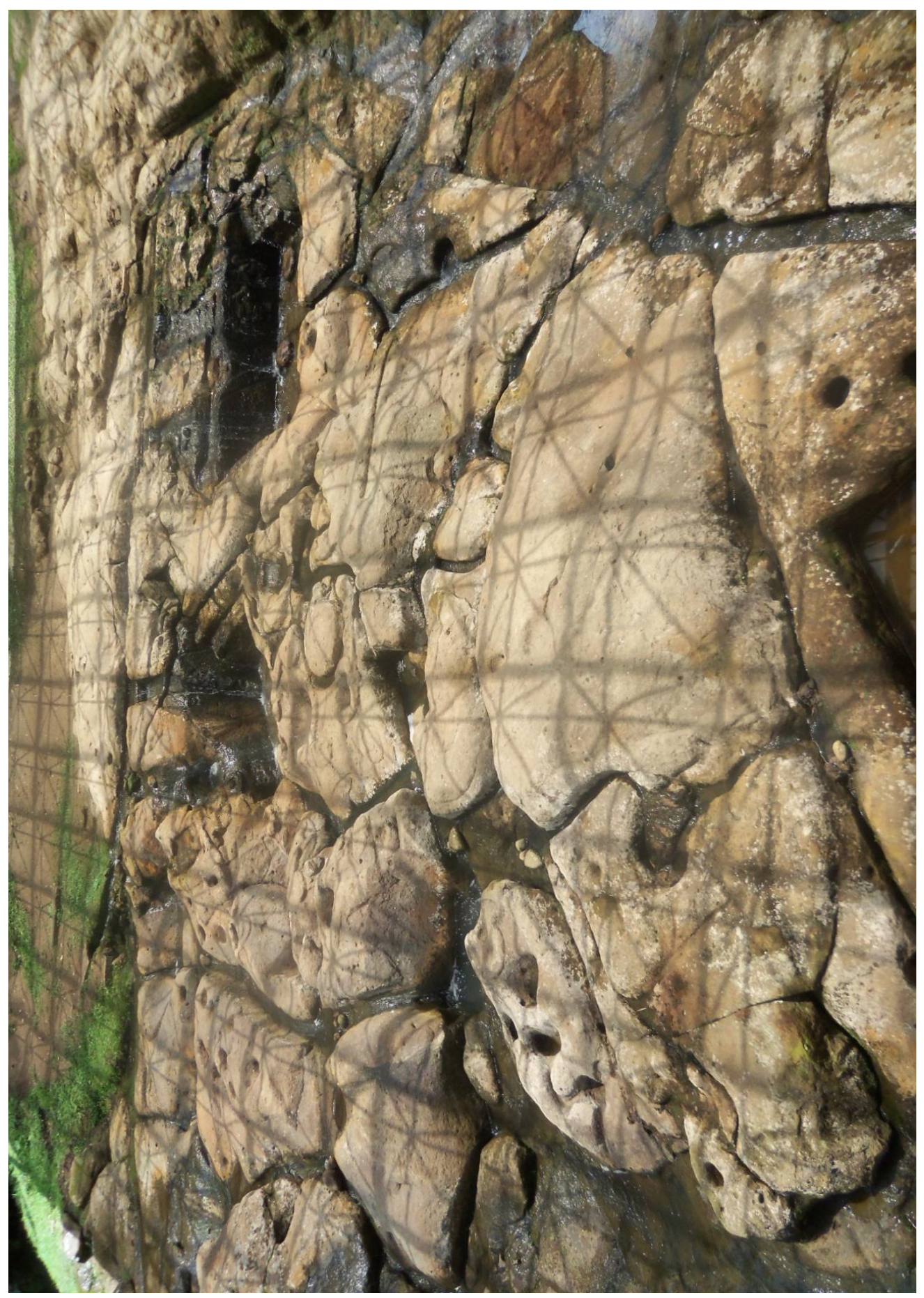


Imagen Detalle de un lado de la fuente del Lavapatas.

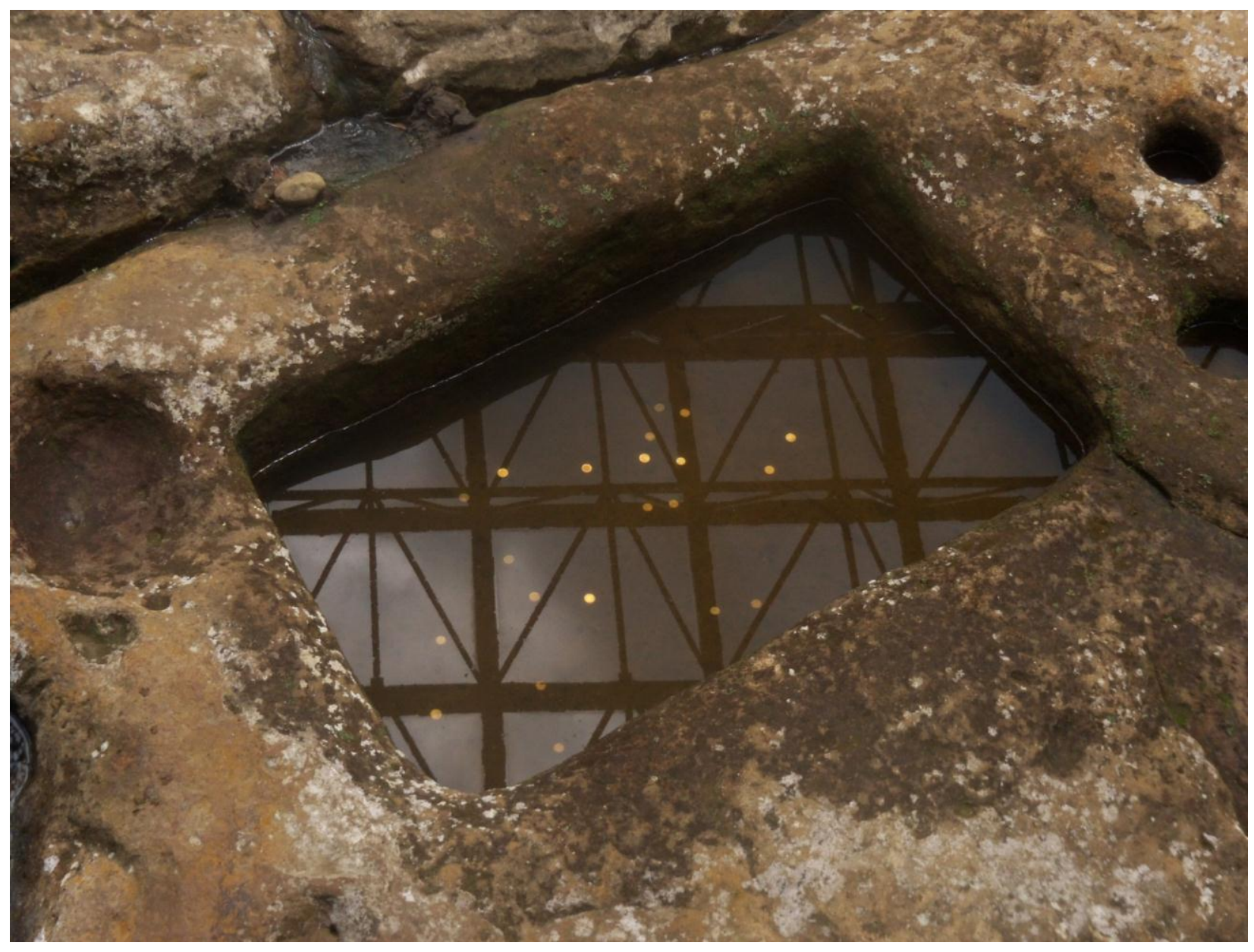


Detalle de la fuente del lavapatas donde se evidencia la roca esculpida. Tomado por Cristina Toro. (2013)

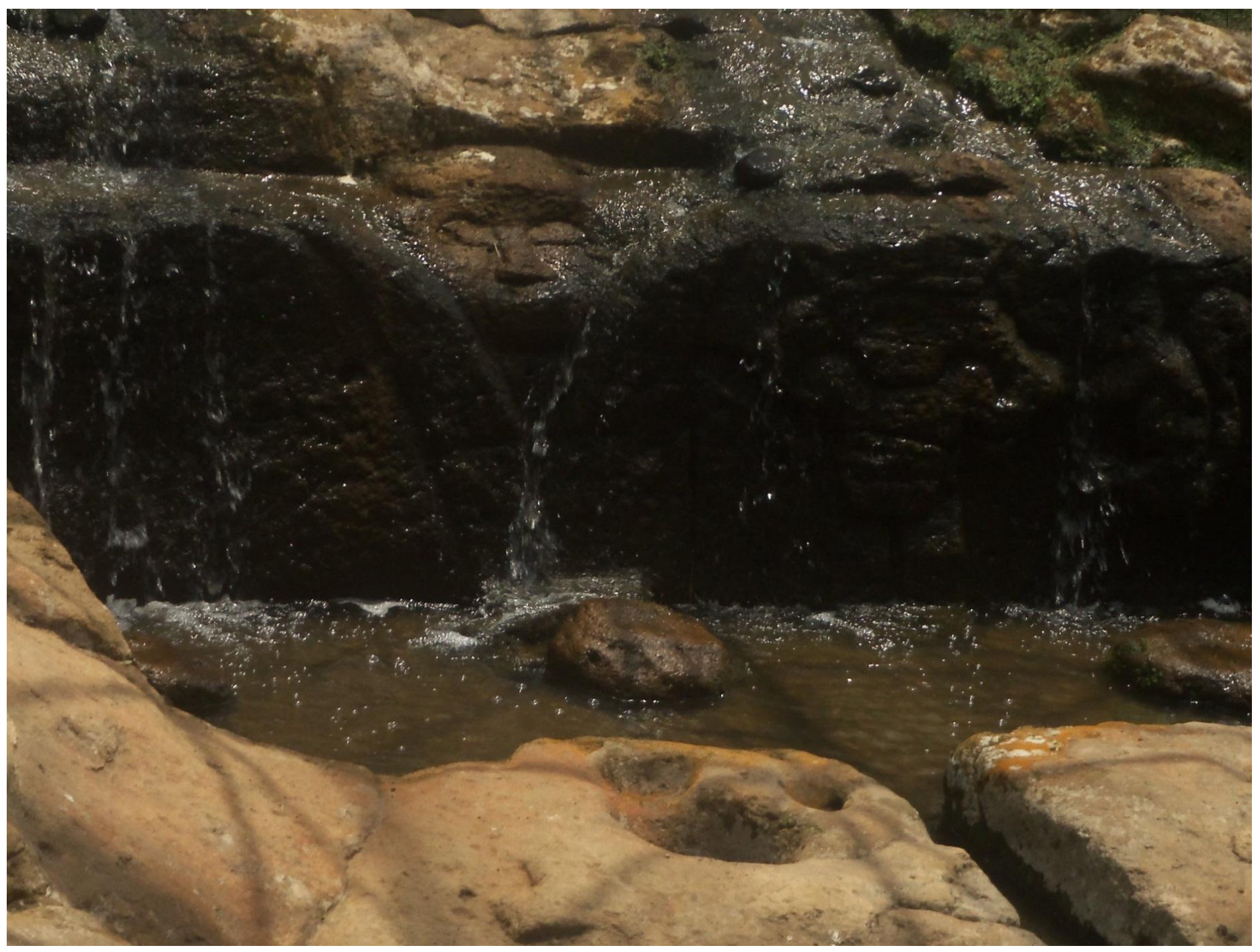


Imagen 5-6 fotografías de la excavacion del lava patas.
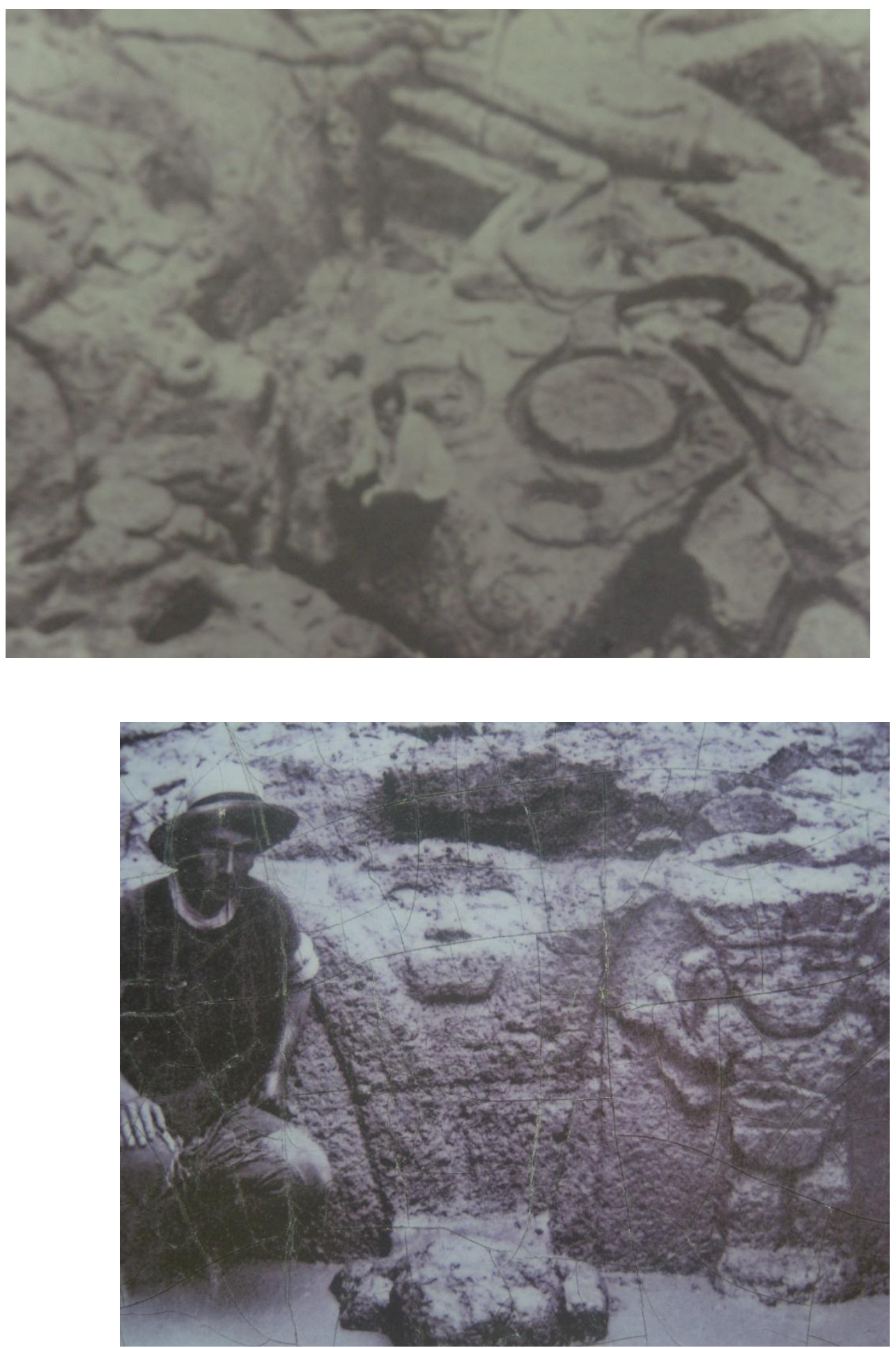
Foto 6, El doble Yo. En el Alto del Lavapatas. Tomada por Cristina Toro. (2013)

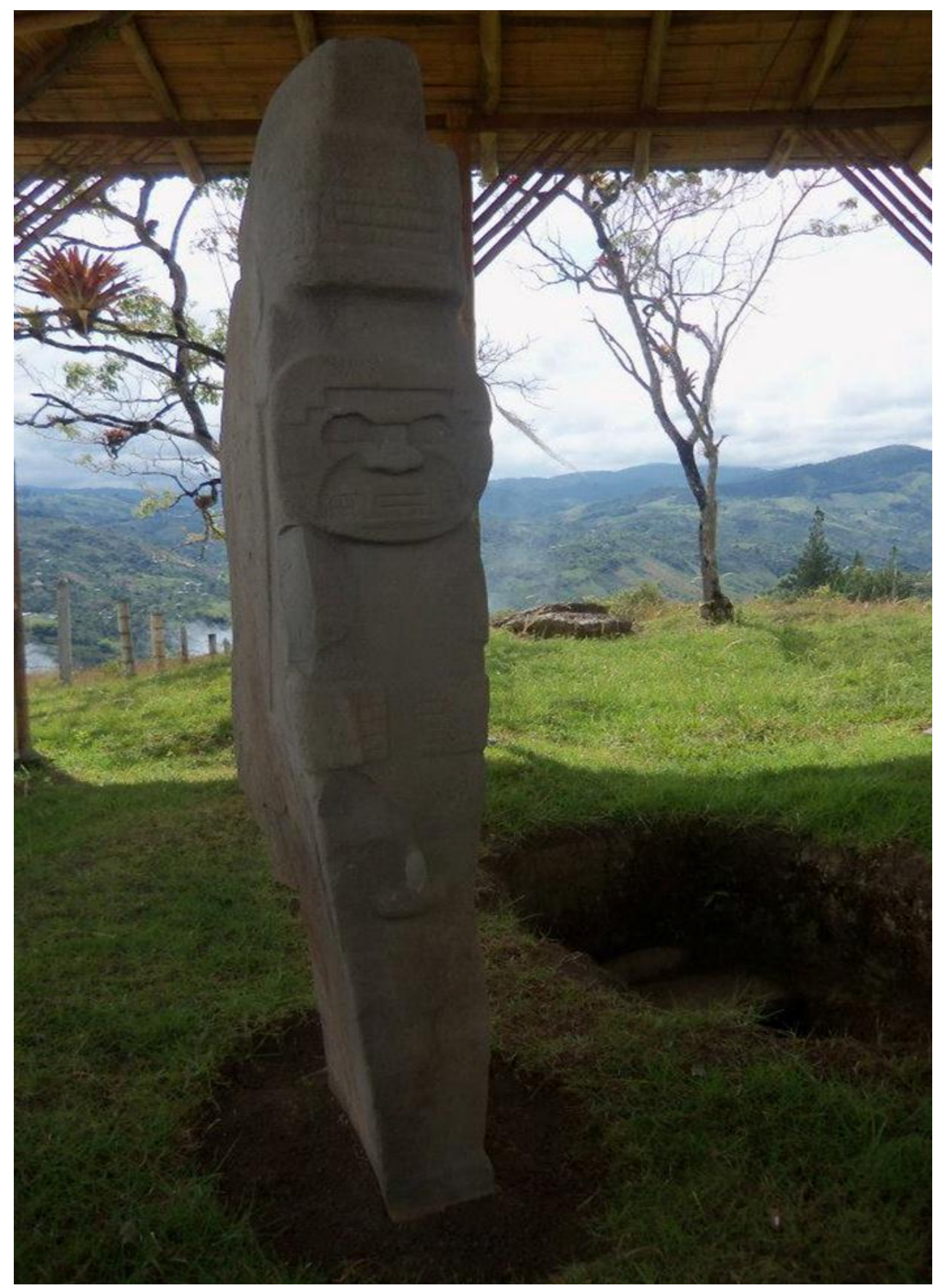


Lateral del Doble yo. En Alto del lavapatas. Tomada por . Cristina Toro (2013)

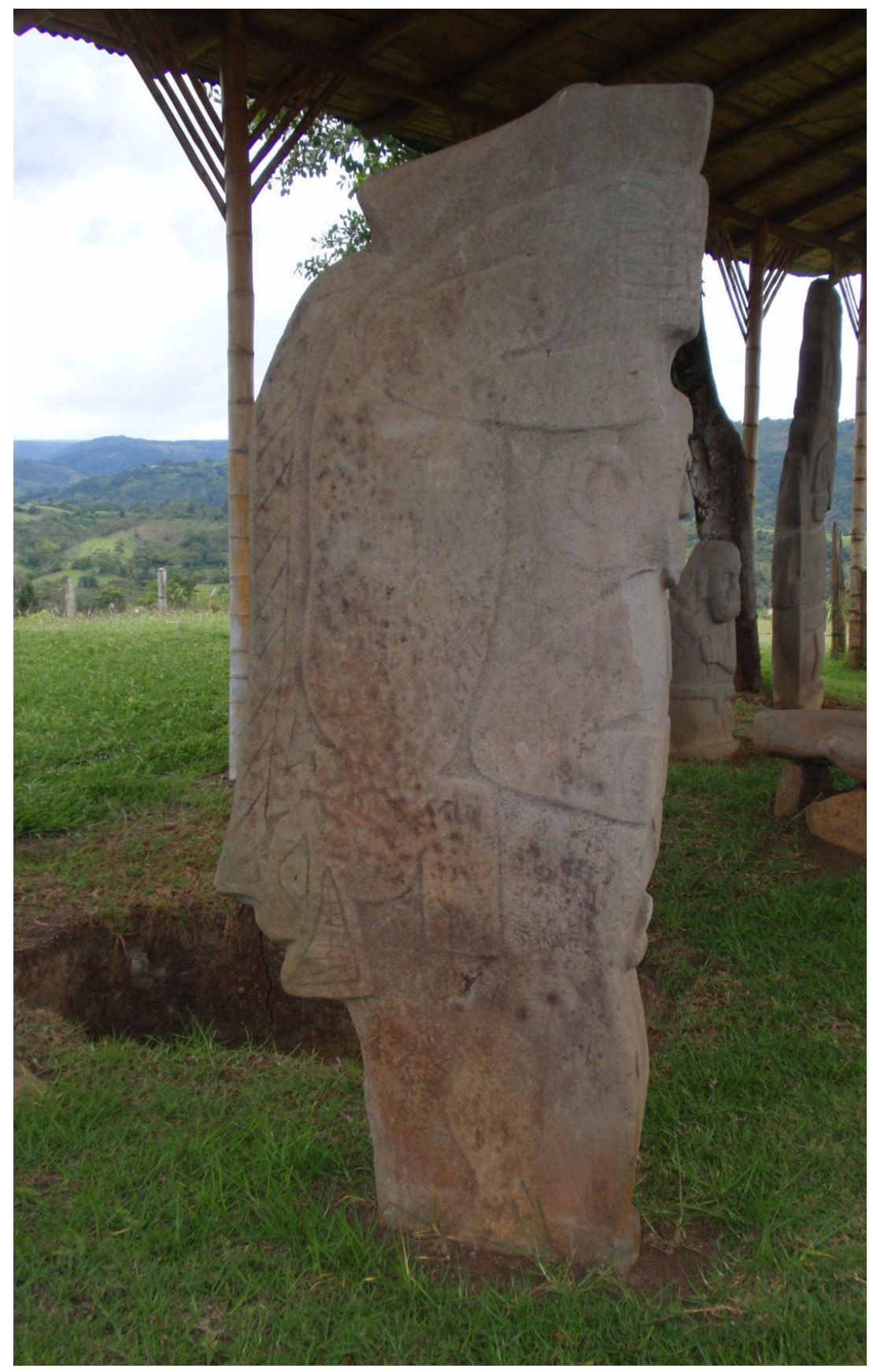


Dibujo del doble yo. Por César Velandia
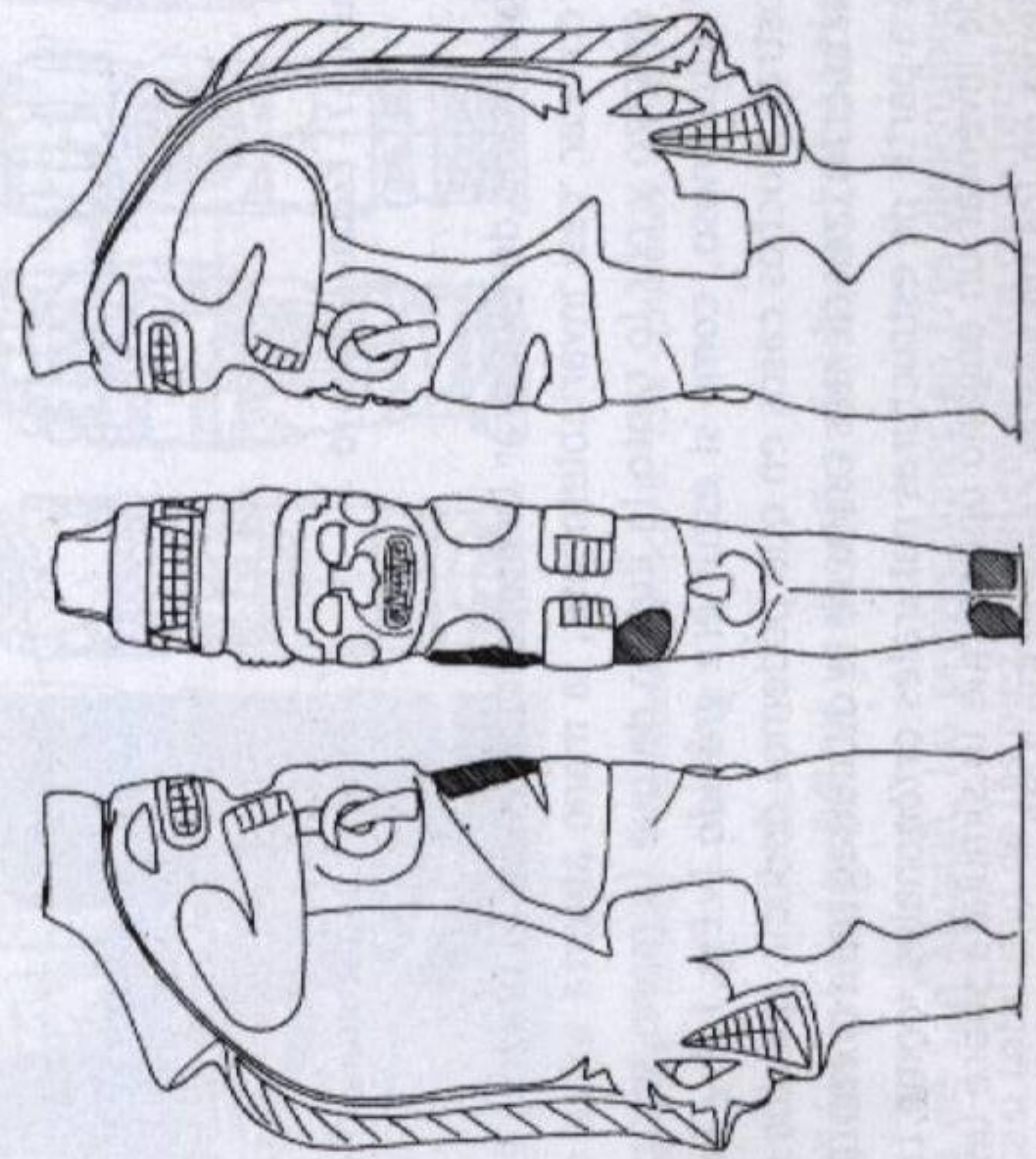
Foto 7. El obispo. En el parque arqueológico de sana gustin. Mesita B. Tomada por Cristina Toro. (2013)

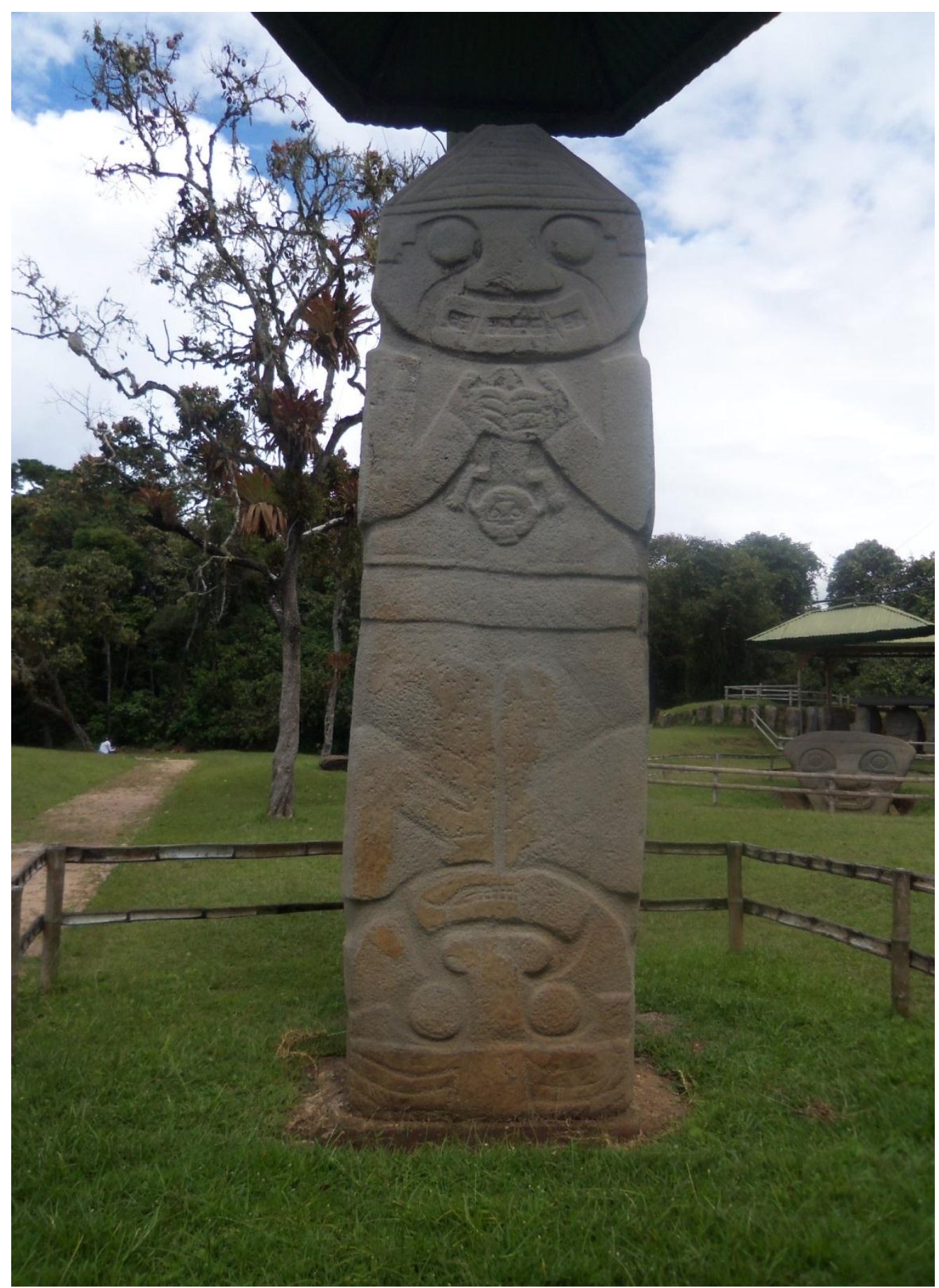


Imagen 7. Dibujo del Obispo realizado por Cesar Augusto Velandia.

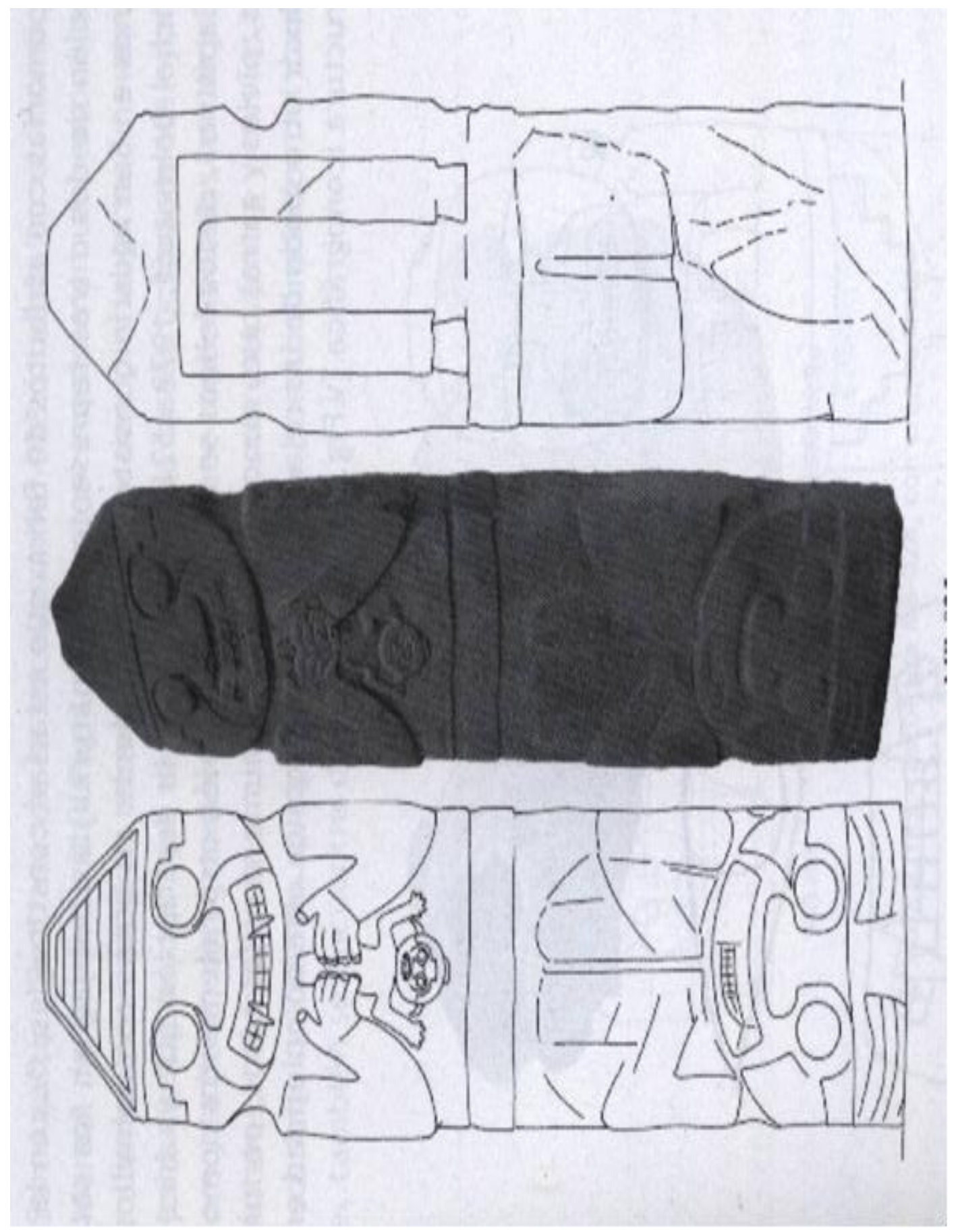


Foto 8. La Fautista. Tomada por: Cristina Toro. (2012)

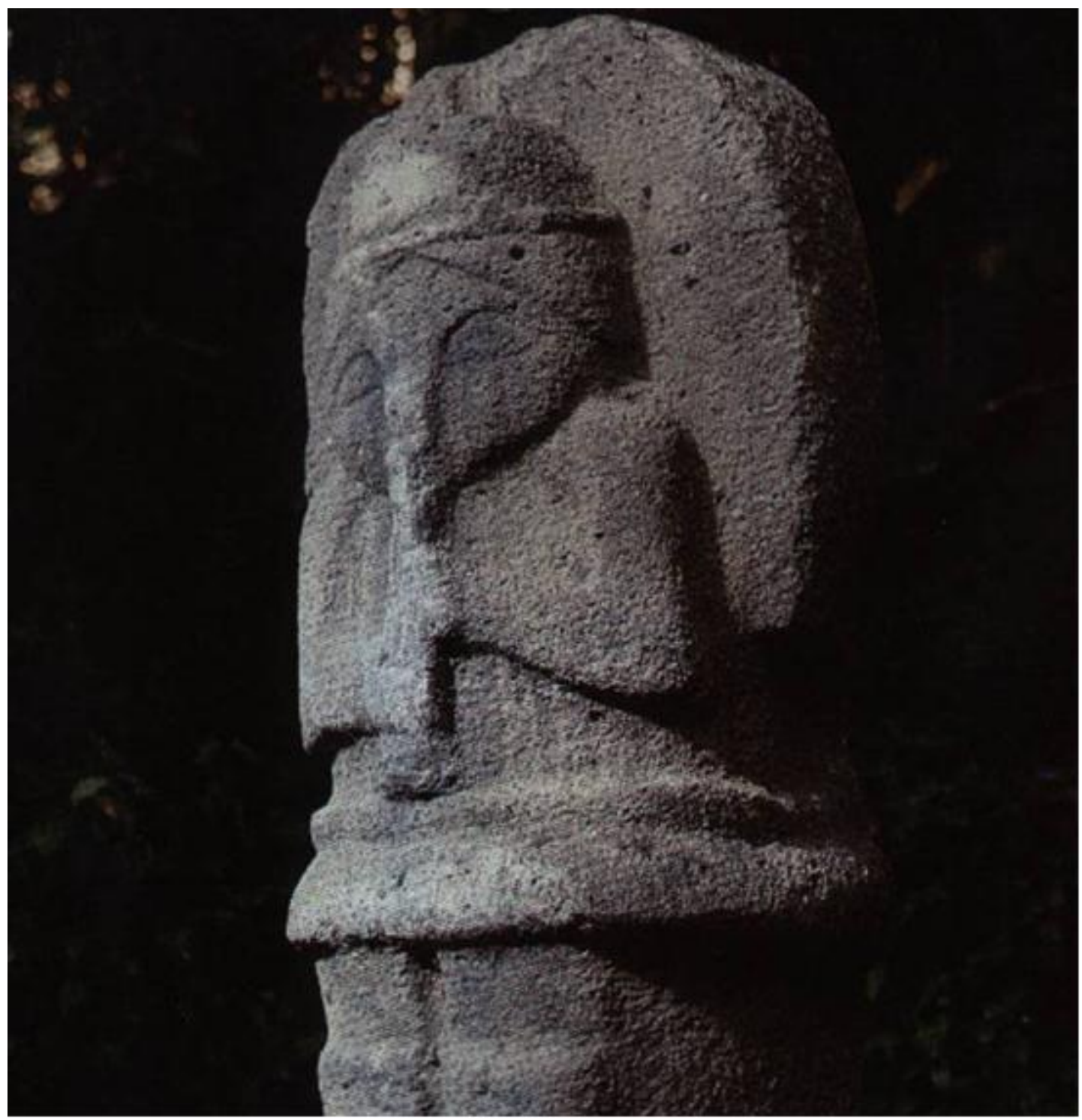


Foto 9. La mujer de vientre abultado. Simbolo de la materenidad. Alto de los ídolos. Tomada por : Cristina Toro.(2012)

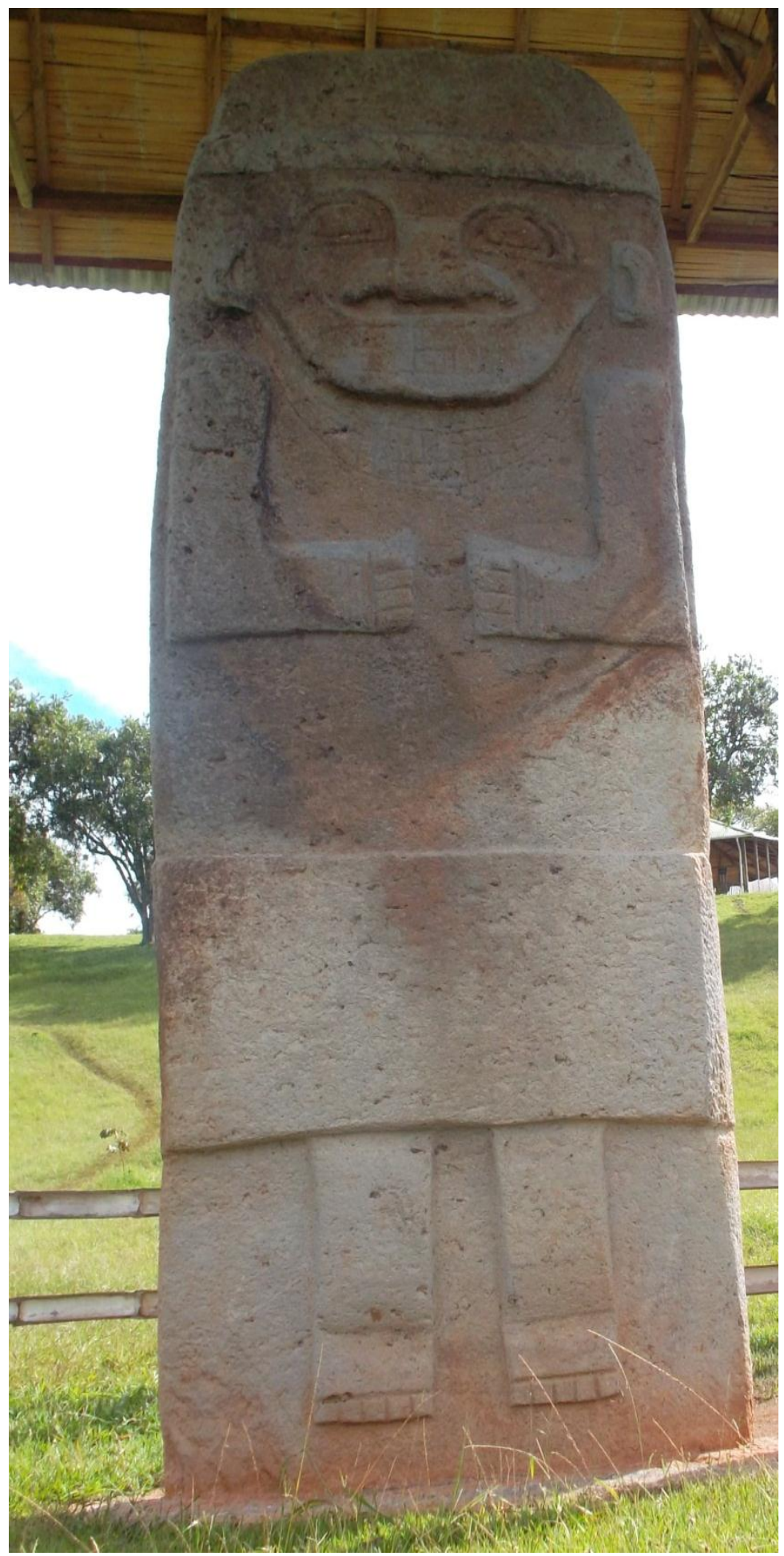


Foto 11. Monticulo. En el alto d elos idolos. Tomada por Cristina Toro (2012)

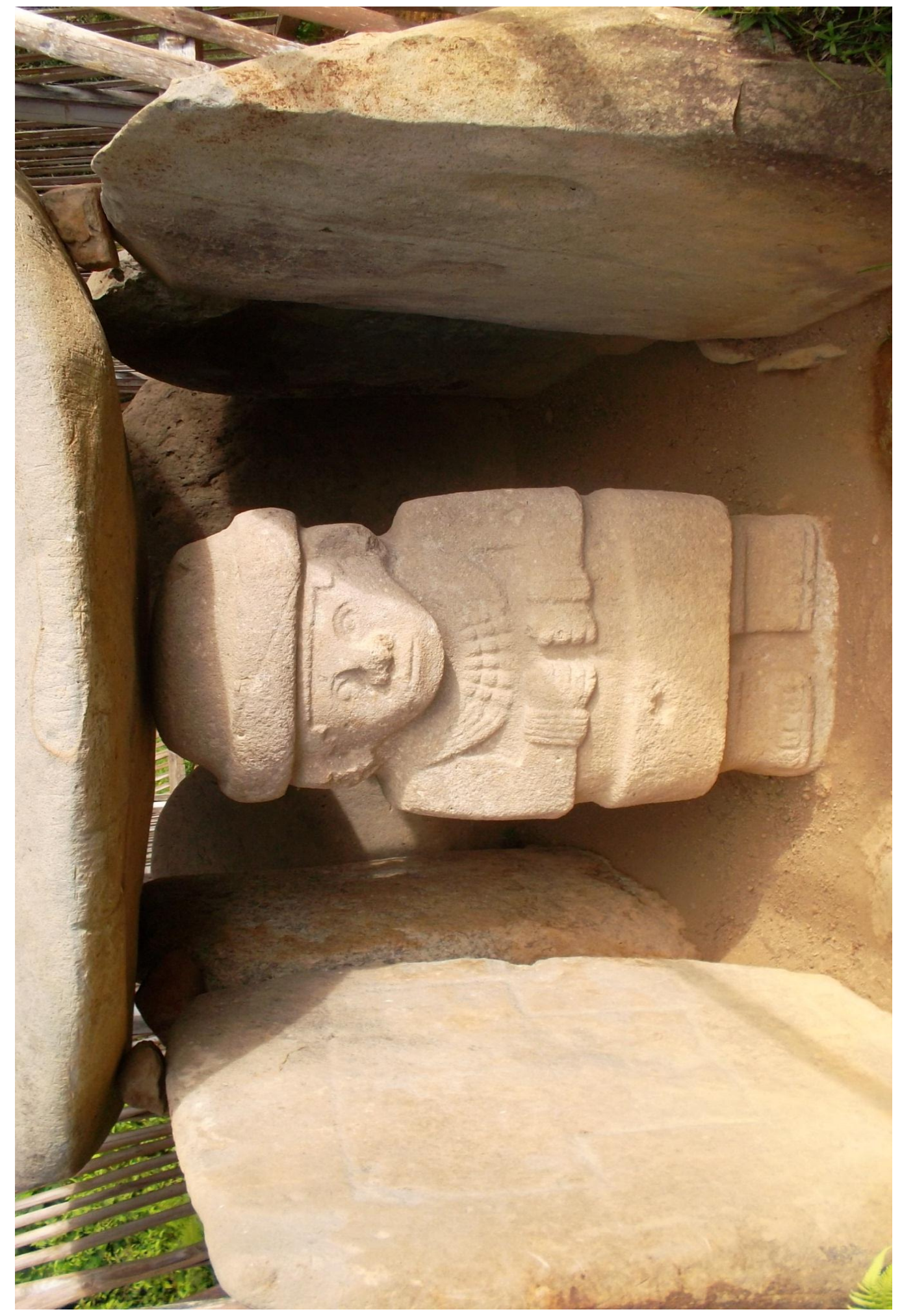


Foto 10. Diosa que muestra un niño. La estatua que esta en el centro, y que se encuantra en el parque arqueológio de San agustin . Tomado por Cristina Toro (2013)

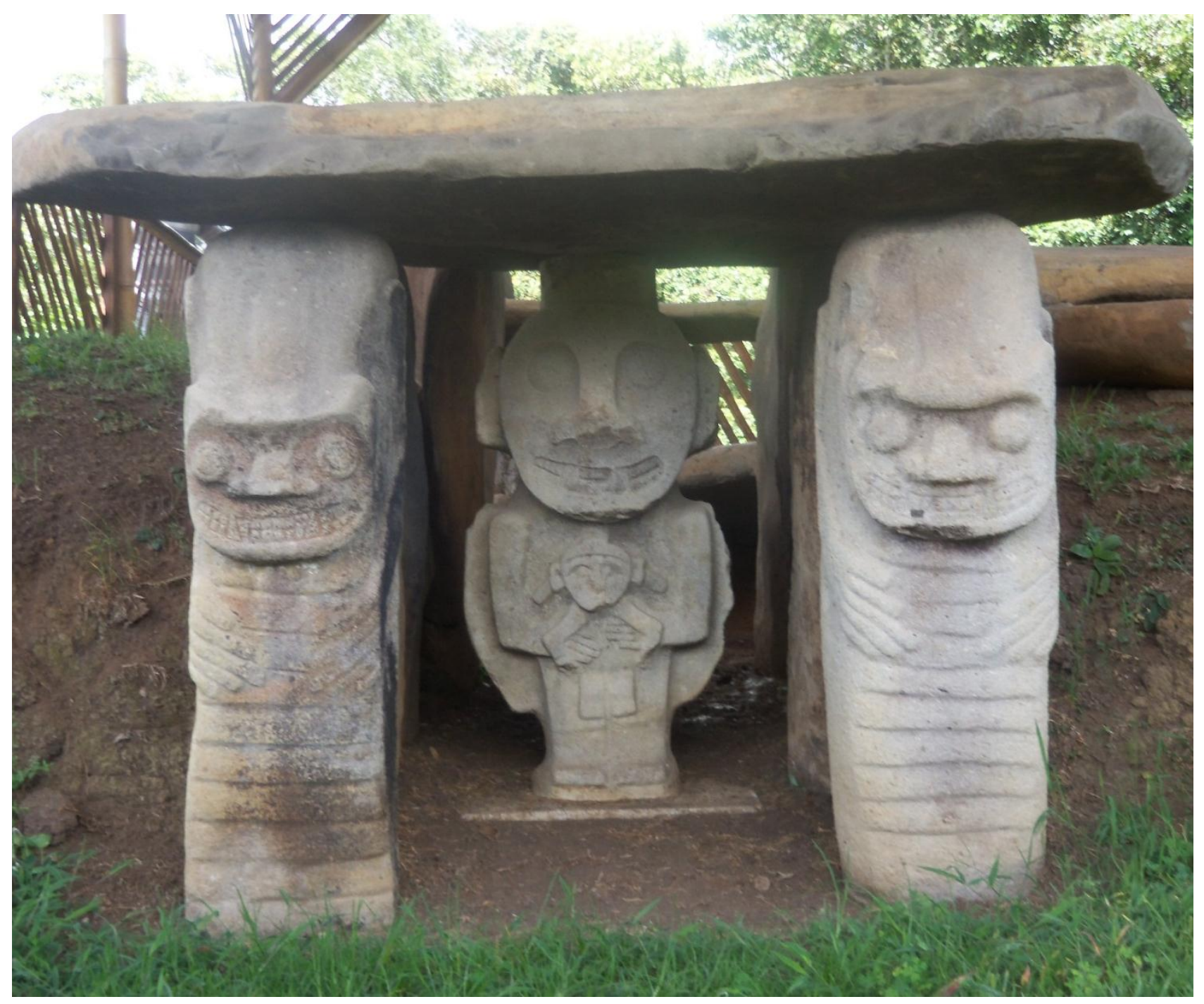


Foto 1 Paisaje. Vista del estrecho del río magdalena desde un mirador.Tomada por Cristina Toro.(2012)

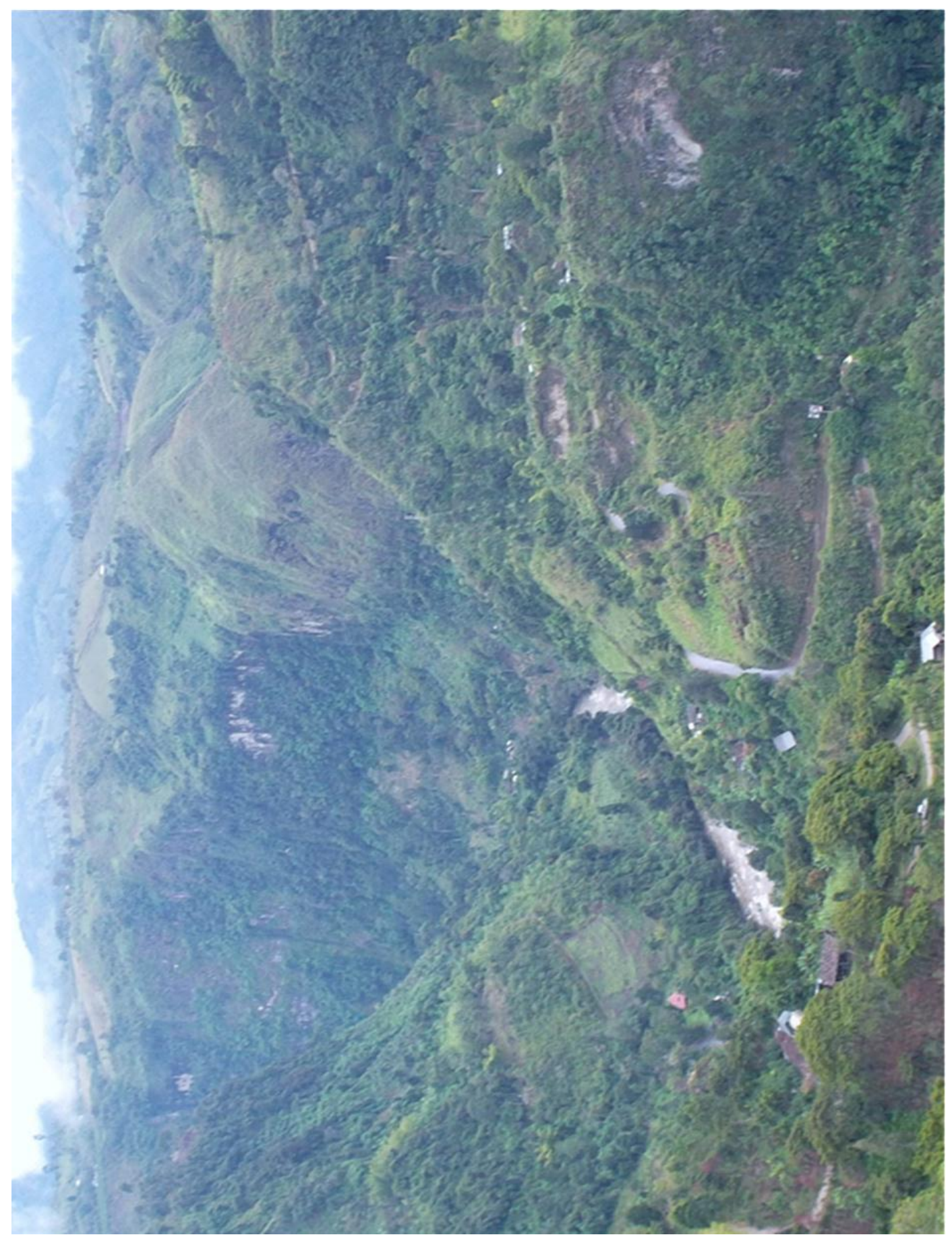


El estrecho del magadalena. Via Obando.Tomada por Cristina Toro. (2011)

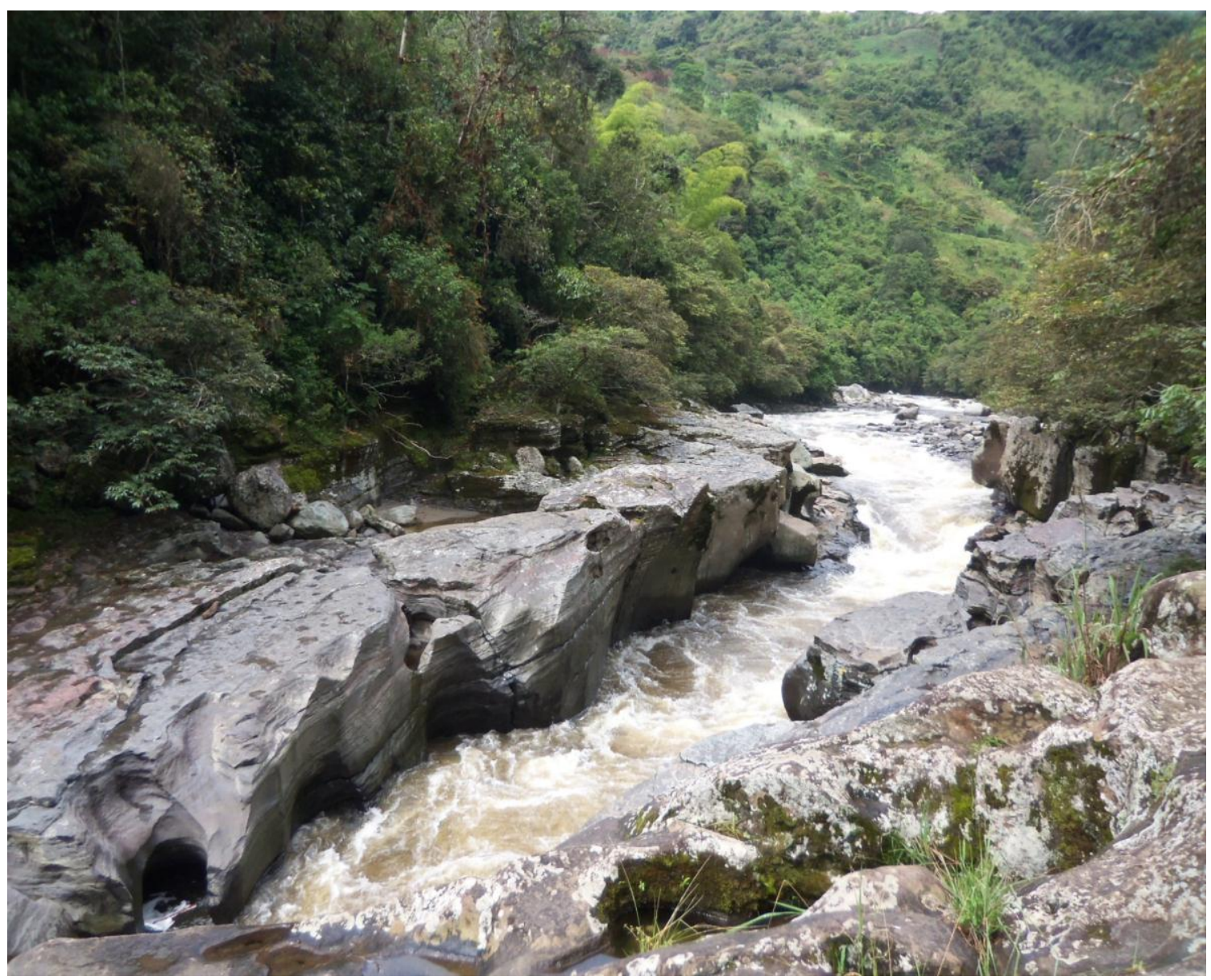


Paisaje. Vista desde el Alto del Lavapatas. Tomada por Cristina Toro. (2011)

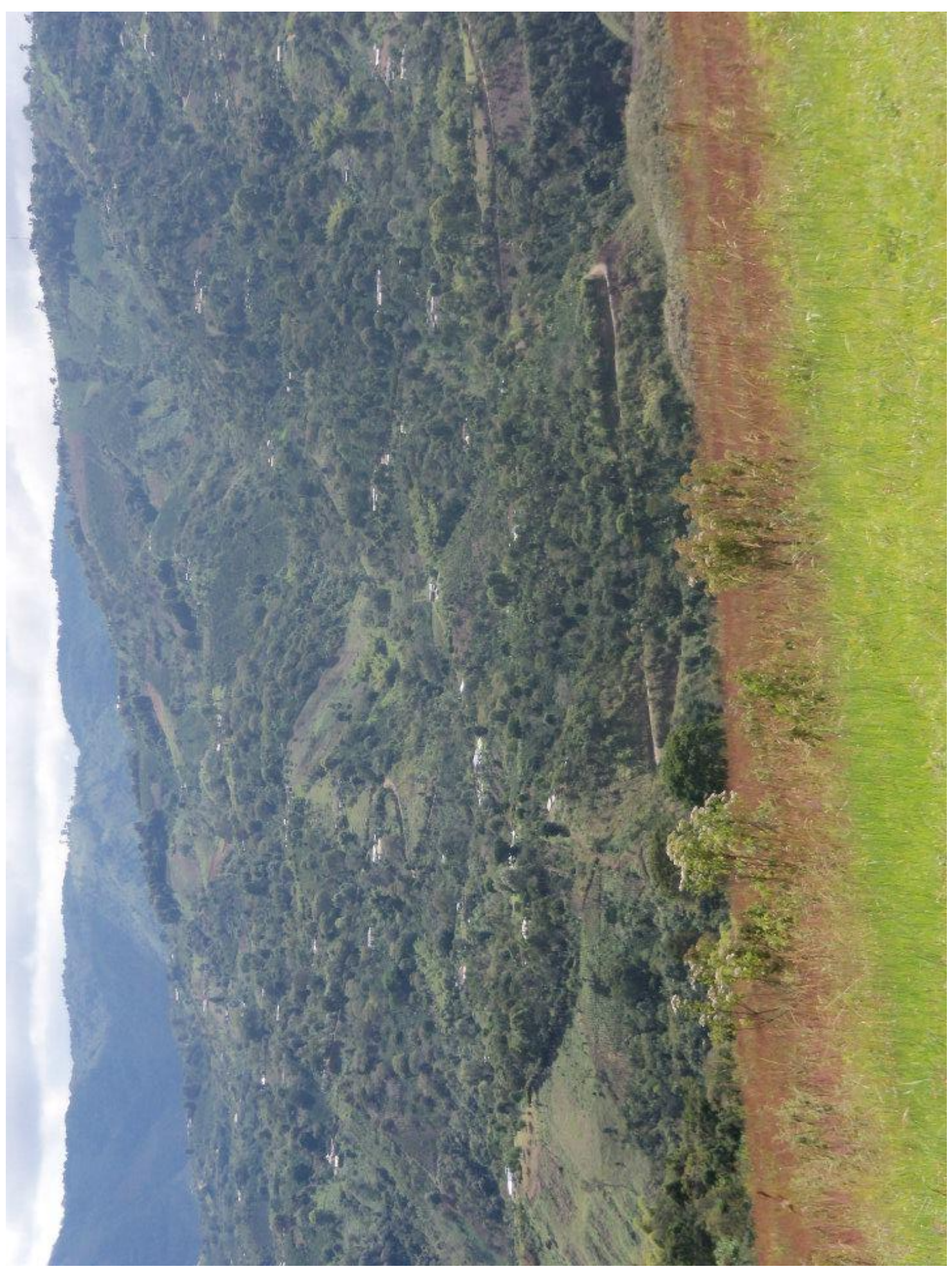


Cuadro 1. En: Gamboa(2007) Esculturas de san agustin.

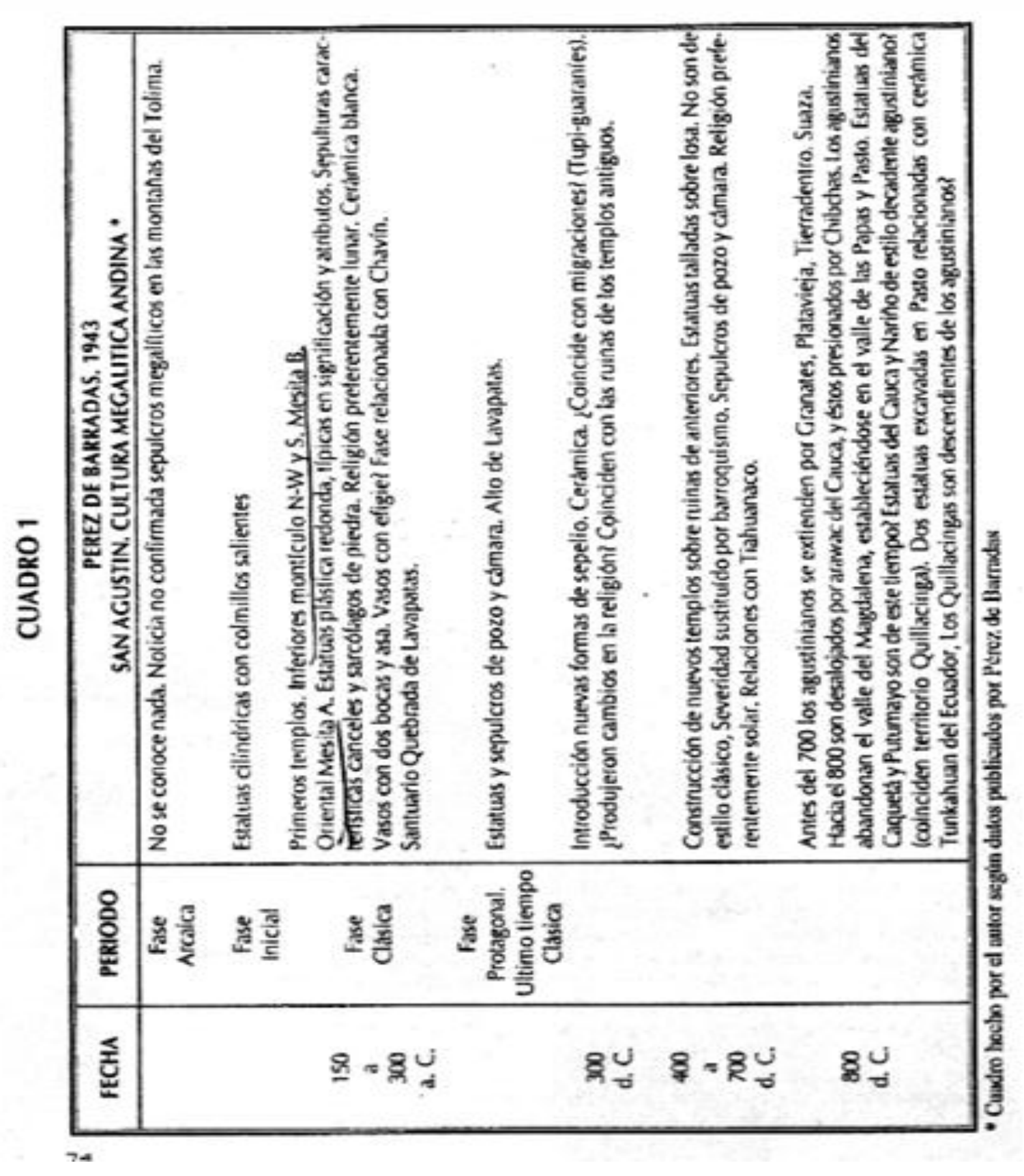


Cuadro 2 cronologia Duque Gomez.

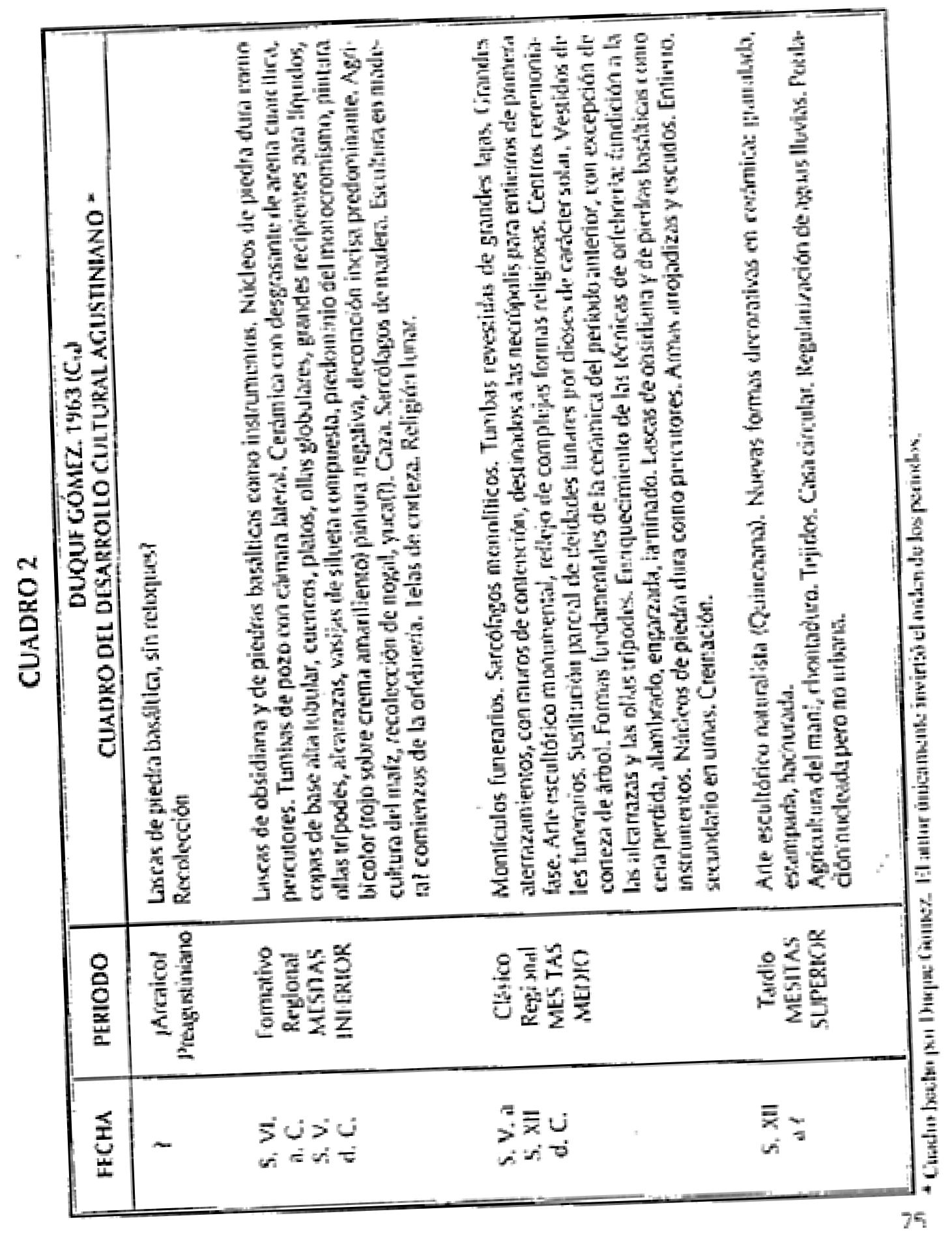


Cuadro 3, cronología. Reichel-Dolmatoff

\begin{tabular}{|c|c|c|c|c|}
\hline 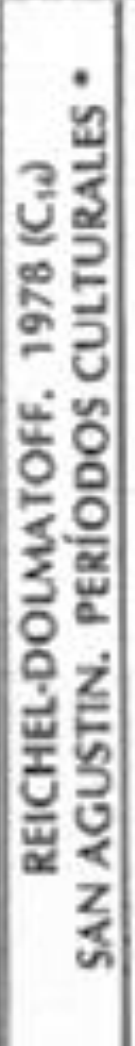 & 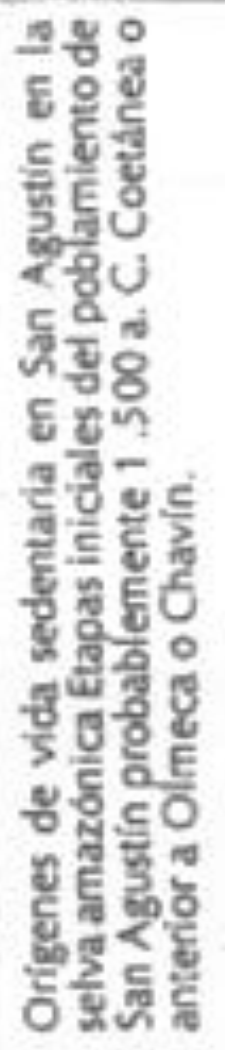 & 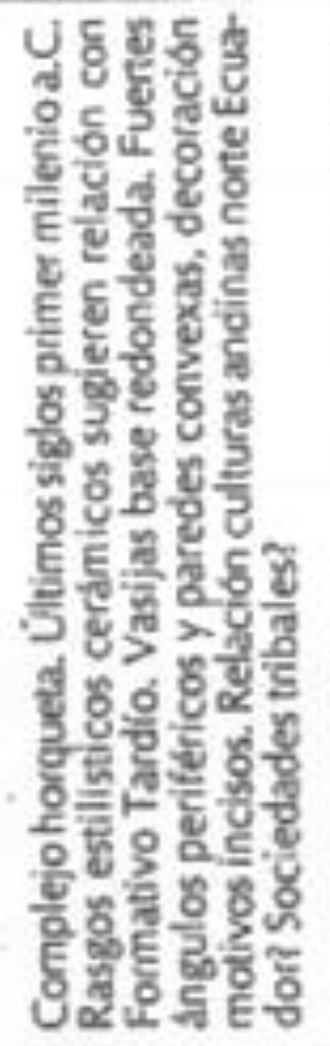 & 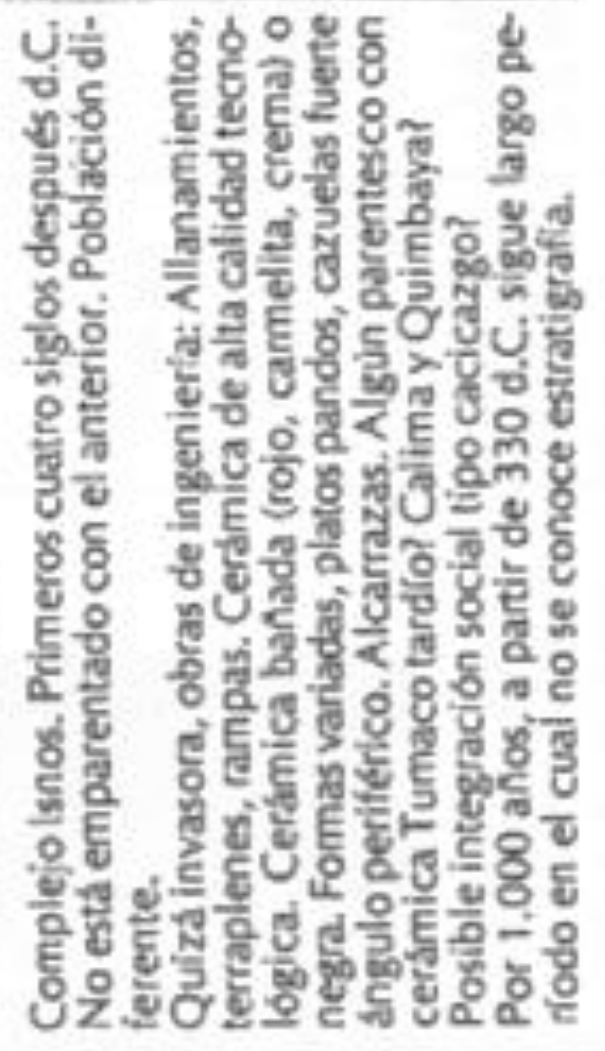 & 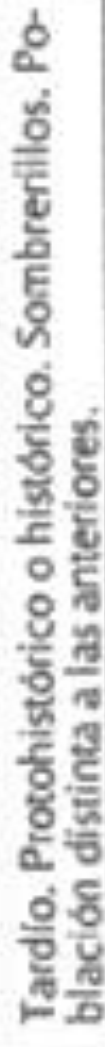 \\
\hline 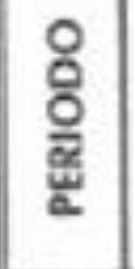 & " & $\frac{\dot{0}}{-0}$ & 영음 & \\
\hline 至 & & & 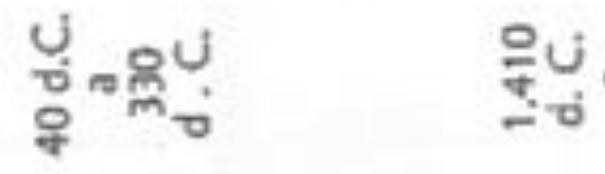 & \\
\hline
\end{tabular}


Imagen 9. Dibujos y numeración por Agustin Codazzi.

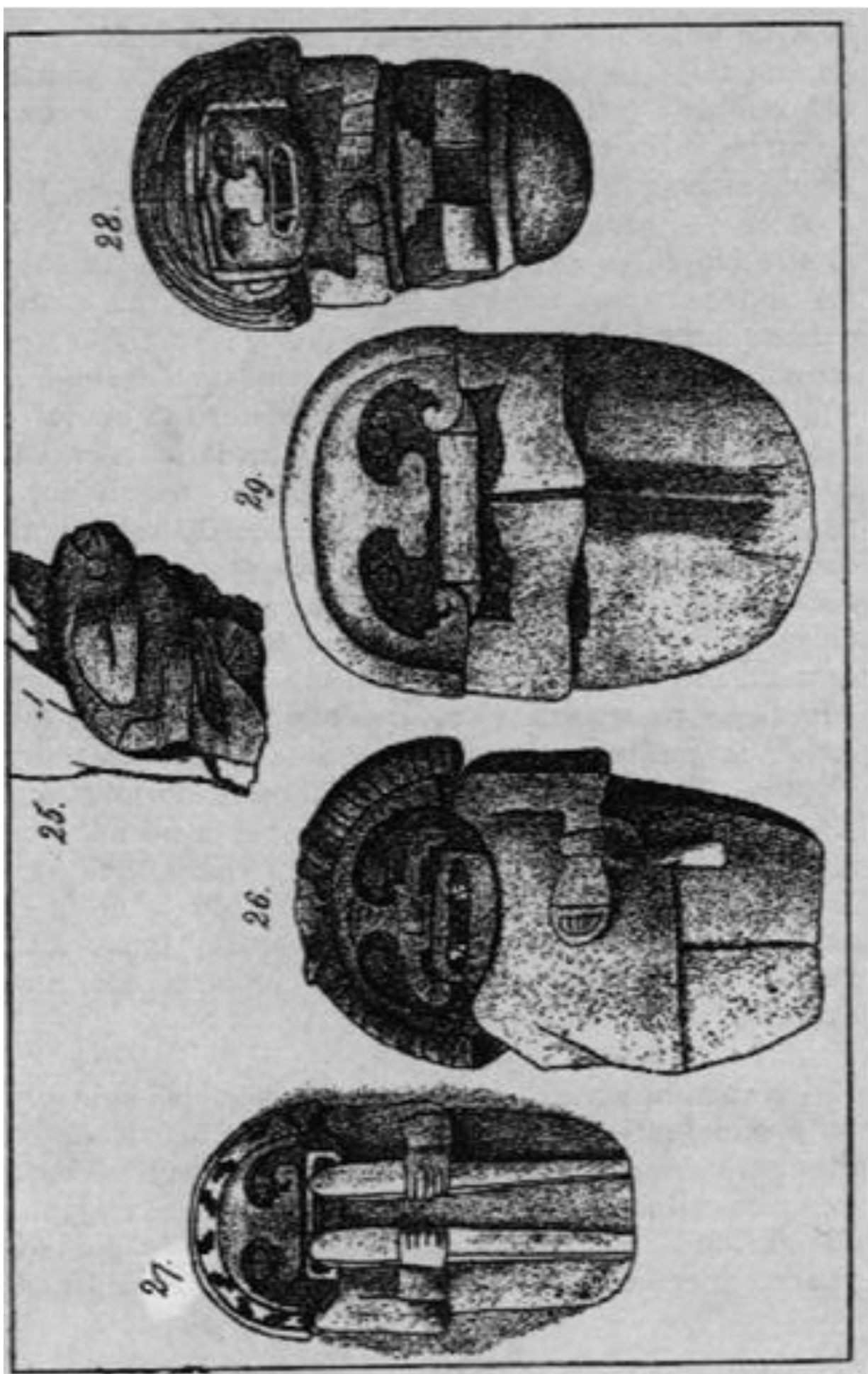


Otra escultura de gran tamaño el parque arqueológico San Agustín. Por Cristina Toro (2013)

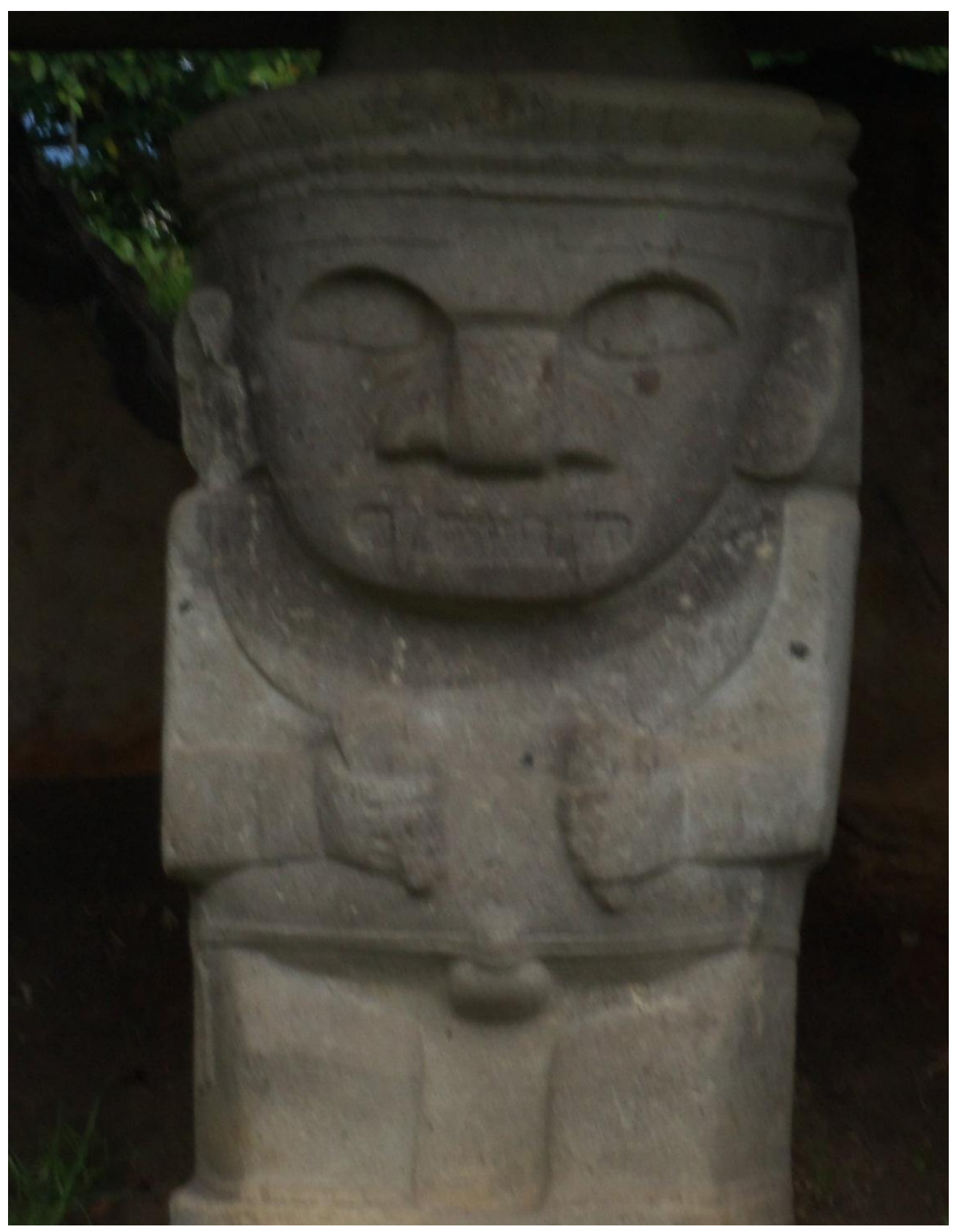


Foto 13. Tumba en el Alto de los Ídolos. Por Cristina Toro (2013)

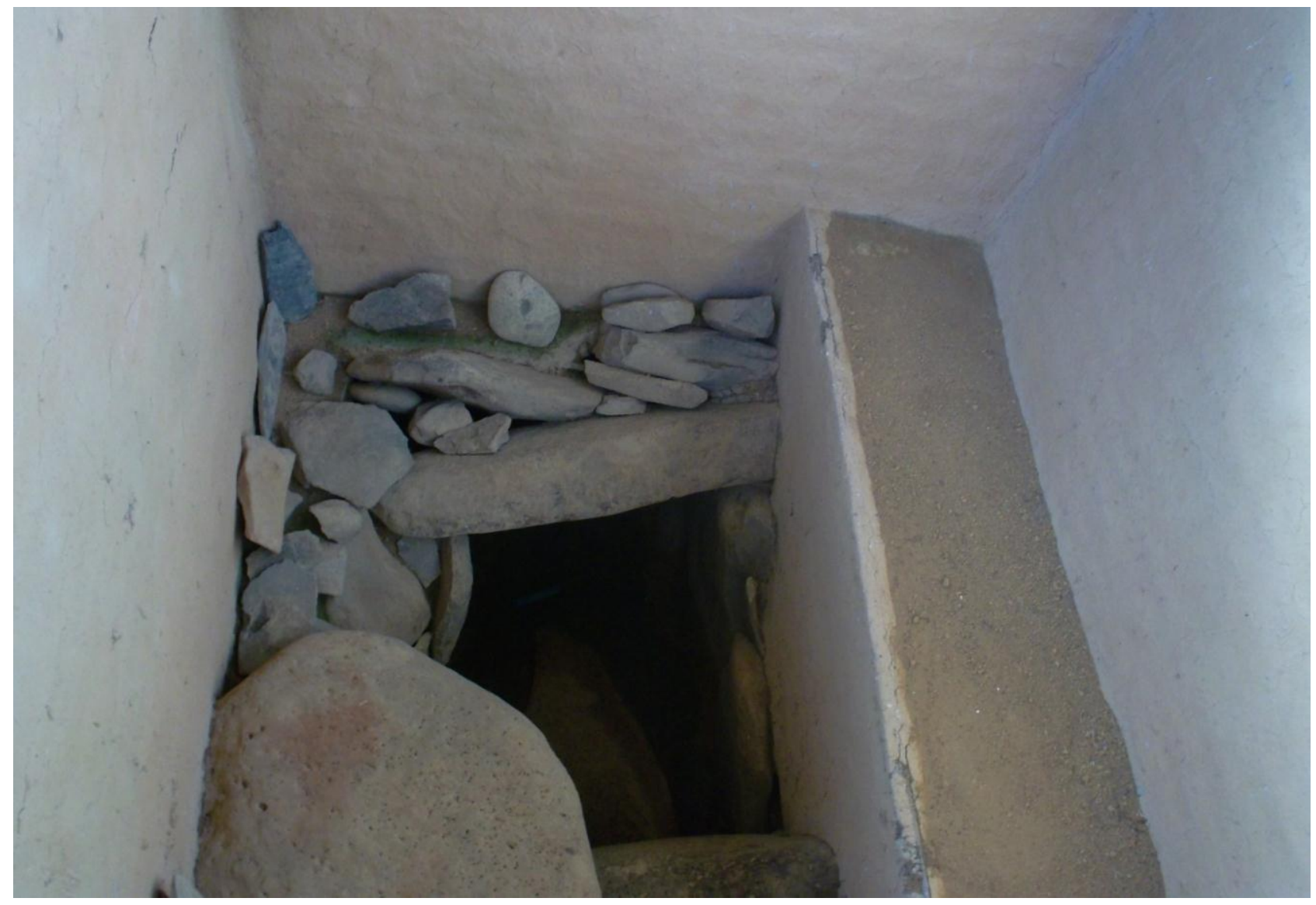


Foto 12 Tumba en el Alto de los Ídolos. Por Cristina Toro (2013)

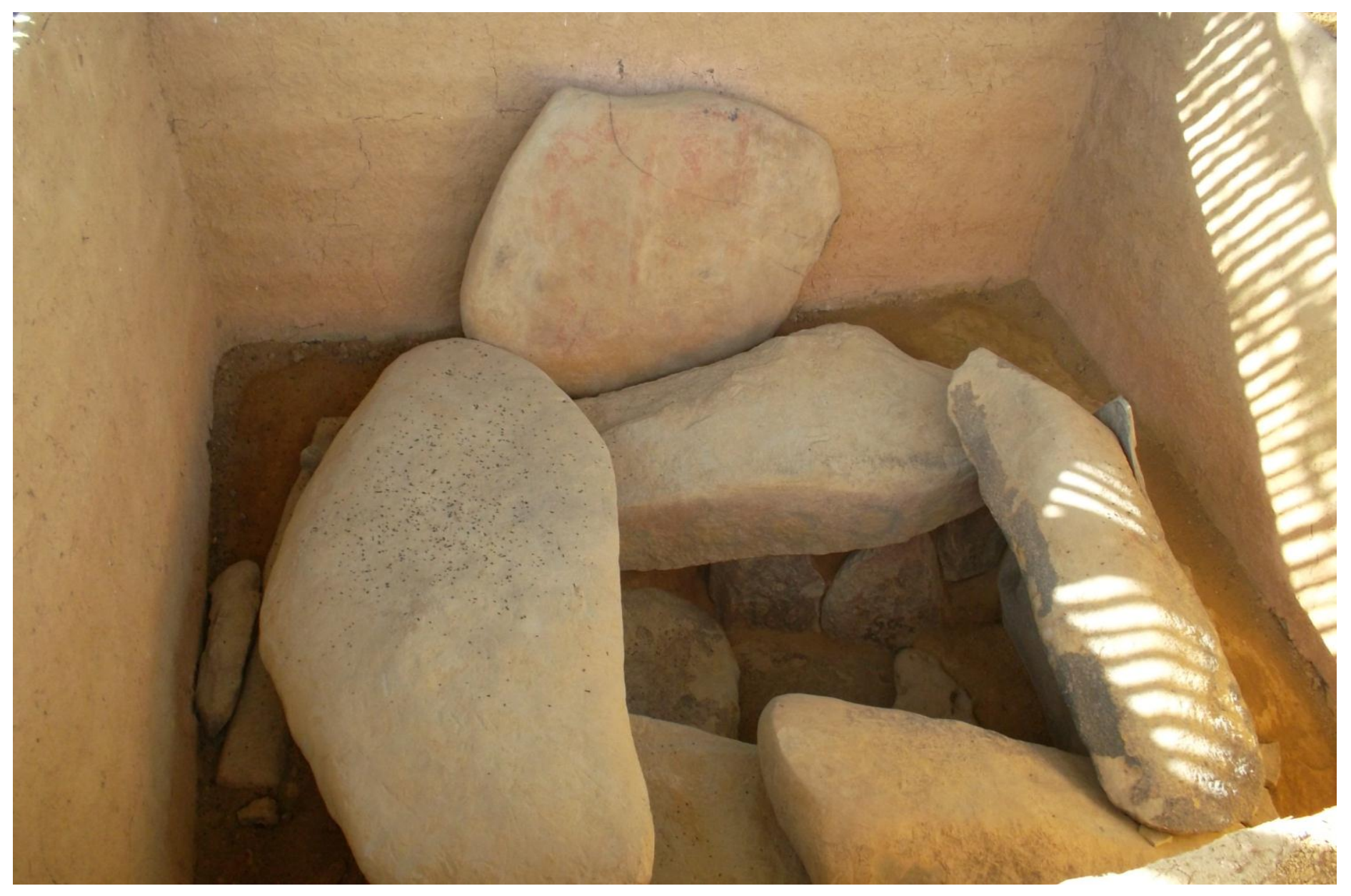


Foto 14. Tumba en el Alto de los Ídolos. Por Cristina Toro (2013)

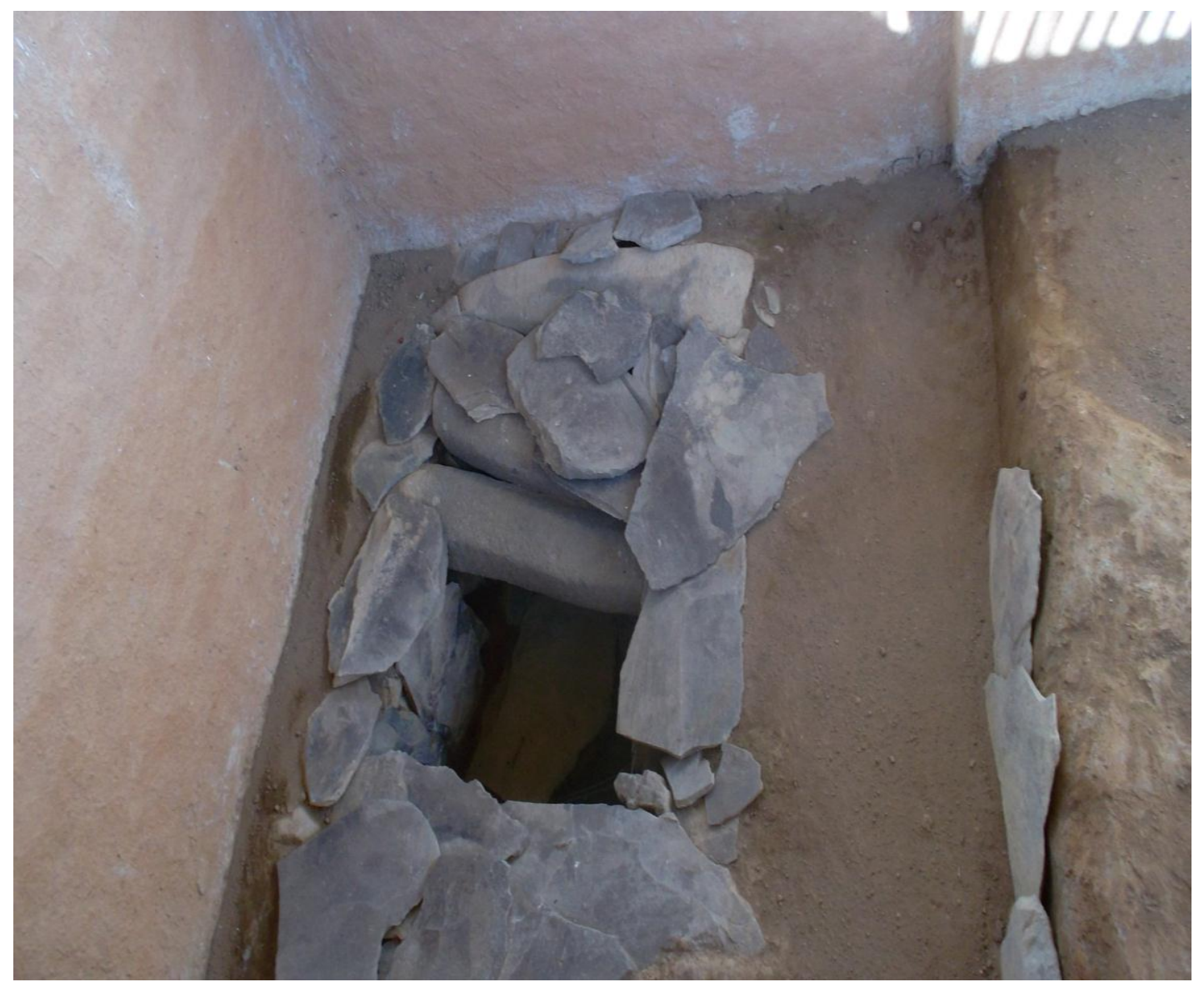


Foto 15 Tumba en el Alto de los Ídolos. Por Cristina Toro (2013)

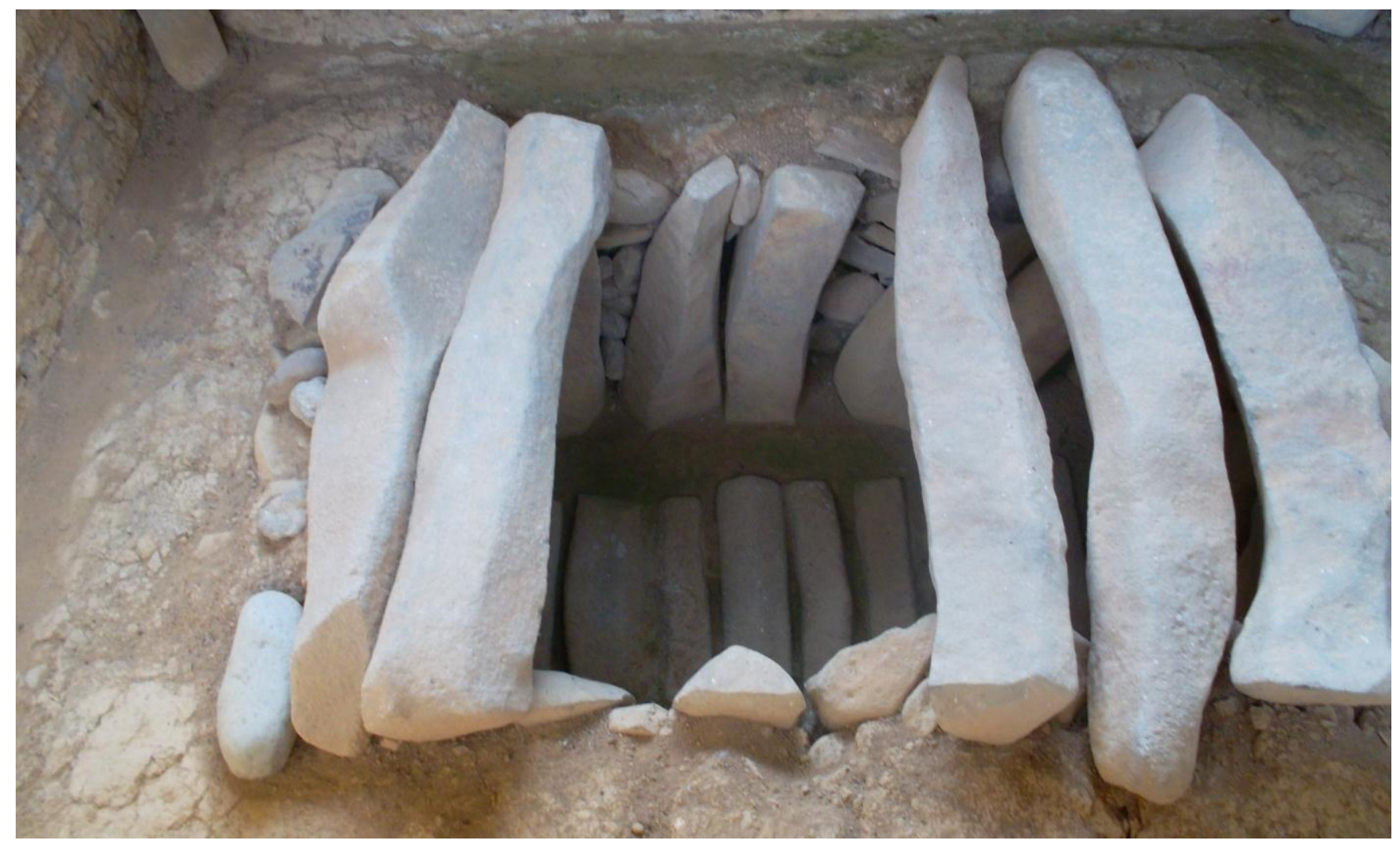


Imagen 8. Orfebrería agustiniana.

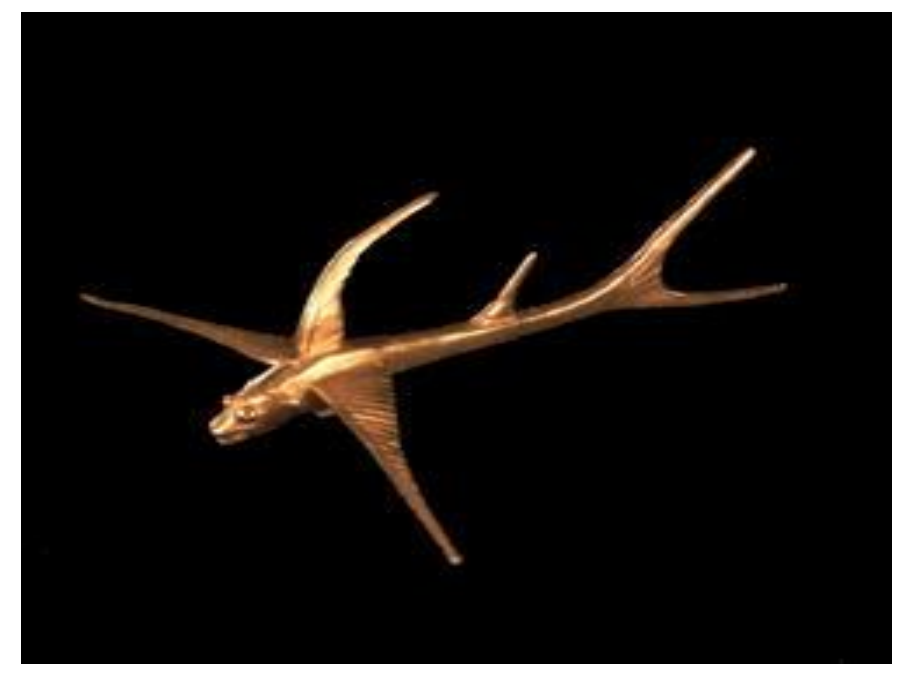

Objeto en oro que era un colgante y data del año 900 a.c. PEZ ALADO

http://www.banrepcultural.org/museo-del-oro/sociedades/san-agustin/en-el-museo

y se encuentra actualmente en el museo del oro.

Parte del ajuar funerario del periodo clásico regional.

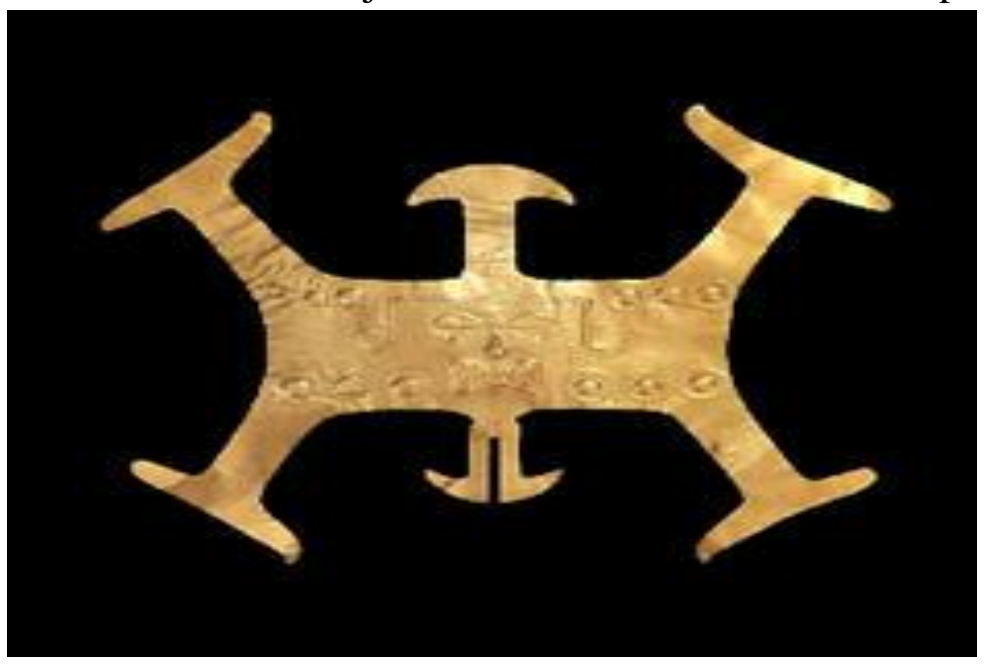


Foto 16

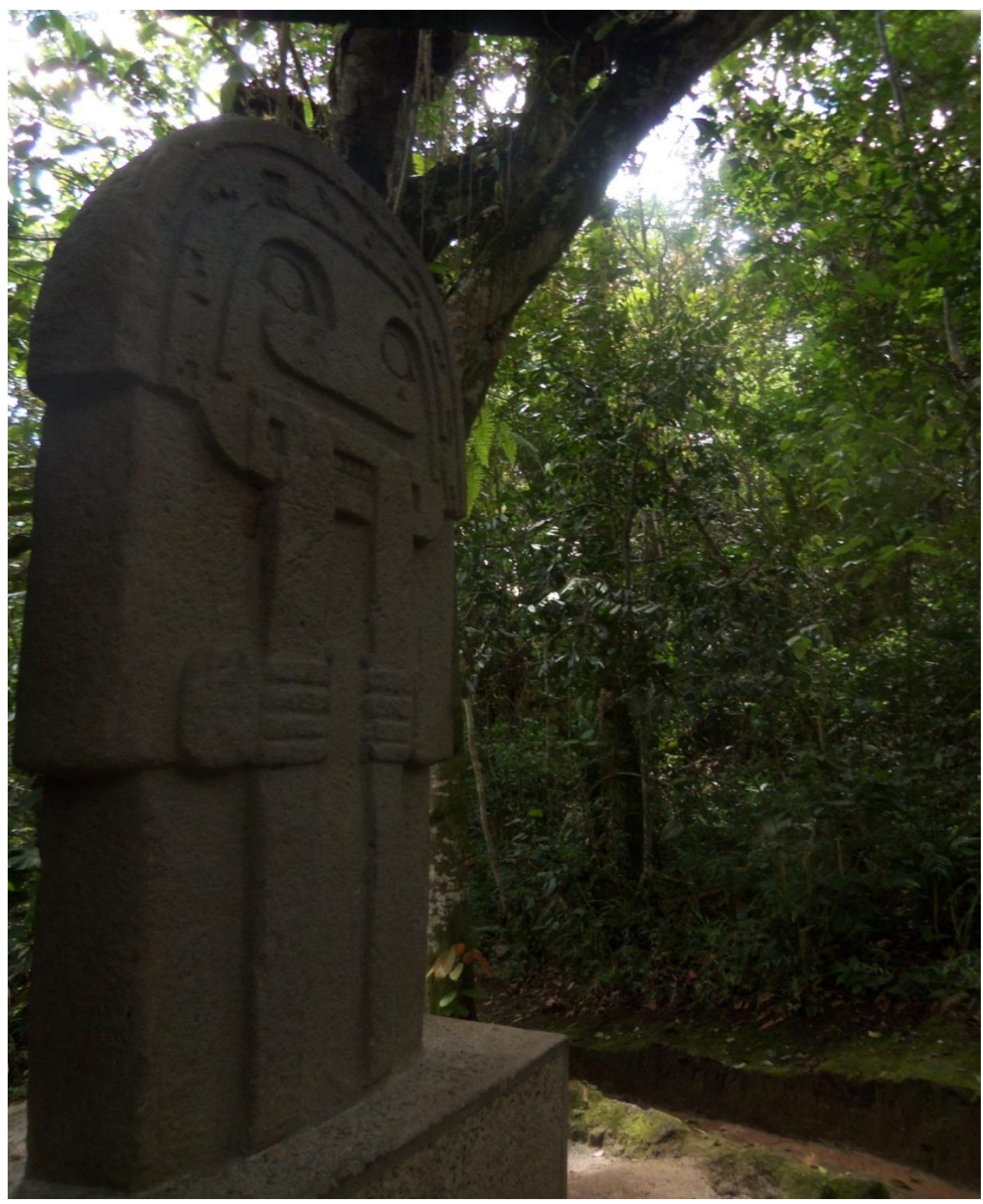




\section{BIBLIOGRAFÍA}

CATAÑO, Gonzalo. (2012) El filósofo Rafael Carrillo, Universidad Pedagógica Nacional Versión en línea.

http://www.google.com.co/url?sa=t\&rct=j\&q=rafael\%20carrillo\%20\&source=web\&cd=9

$\underline{\& c a d=r j a \& v e d=0 C E w Q F j A I \& u r l=h t t p \% 3 A \% 2 F \% 2 F w w w . r e v i s t a . u n a l . e d u . c o \% 2 F i n d e x . p ~}$ hp\%2Fidval\%2Farticle\%2Fdownload\%2F21815\%2F22791\&ei=joOuUeHaM4_Q9ASc0I

DIAg\&usg=AFQjCNH2_bF-1A6LL_tnxzsQ9DLIZRVrwg\&bvm=bv.47244034,d.eWU

CODAZZI, Agustin. (1863) Antiguedades indígenas. Ruinas de san agustion, descritas y explicadas por A. Codazzi. EN: Jeografía física II. Política de los estados unidos de Colombia. Memoria publicada por Felipe Pérez. Pag. 400- 446.

CHAVEZ BÁEZ, Román Alejandro (2005) Arte y fenómeno. Una sistematización de la estética husserliana a partir de Ideas., Universidad Iberoamericana. Tesis de maestría: México. (Versión pdf)

DELLENBACK. David, (2012) The statues of the pueblo escultor. San Agustin and the macizo colombiano. (ed. independiente): Huila.

DUQUE L. (1964) Exploraciones Arqueológicas en San Agustín, Instituto Colombiano de Antropología, Revista Colombiana de Antropología, Imprenta Nacional, Bogotá.

DUQUE, L. CUBILloS, J. (1979) Arqueología de San Agustín, Alto de los Ídolos Montículos y Tumbas. Fundación de Investigación arqueológica Banco de la República, Bogotá.

DUFRENNE, Mikel, (1982) Fenomenología de la experiencia estética. Vol I. El objeto estético. Valencia: Fernando Torres-editor S.A Versión en línea.

http://es.scribd.com/doc/117657317/Fenomenologia-de-la-experiencia-estetica-vol-1

EMBREE, Lester (2009) Introducción al Panel acerca del quinto estadio de la fenomenología. EN: Acta fenomenológica latinoamericana. Volumen III (Actas del IV Coloquio Latinoamericano de Fenomenología) Morelia (México), Universidad Michoacana de San Nicolás de Hidalgo, 2009 pp. 162. PDF en línea. http://www.clafen.org/AFL/V3/159-167_Embree1.pdf 
FREIDE, Juan (1948) Historia de los indios Andaki del valle del suaza. Revista de la Universidad Nacional de Colombia. No. 13 dic. Bogotá. pág. 109-158.

FISCHER, Ernest, (2010) The necessity of art. Verso: London.

FOUCAULT, Michel. (2011) Manet and the object of painting. Tate publishing: London. (2005) El orden del discurso. Tusquest: Barcelona.

(1999) Espacios diferentes. En: Obras Esenciales, Vol. III, pág. 431-441. Paidós: Barcelona.

GARCÍA, Maria Inés. (2006) espacio y poder. Mexico: universidad autónoma metropolitana de mexico.

GADAMER, Hans-Georg (1993) Verdad y Método I. Ediciones Sígueme: Salamanca. (2001) El enmudecimiento de la obra de arte. En: Estética y hermenéutica. Segunda edición. Tecnos: Madrid

GAMBOA HINESTROSA, Pablo (2007) Esculturas de San agustín. Una de las siete maravillas de Colombia. Editorial Carrera $7^{\mathrm{a}}$ : Bogotá

GOMBRICH, E.H. (2006) The preference for the primitive. Phaidon: London. (2011)The story of art. Phaidon: London

HENRY, Michel. (2008) Ver lo invisible. Acerca de Kandinsky. Siruela: Madrid (2010) Fenomenología de la vida. Prometeo Libros: Bs As.

HERBER, Read (1994) El arte de la escultura. Editorial eme: Bs As.

HERRERA Daniel (2002) La persona y el mundo de su experiencia. Bogotá: Universidad San Buenaventura.

(2009) Nosotros y la fenomenología. EN: Por los senderos del pensar. Bogotá: Universidad San Buenaventura. Pág. 288- 312.

HELTMUTH, Plessner Con Husserl en Gottinga. Pág. 359-372 
HUSSERL, Malvine (2010) Esbozo de una semblanza de Edmund Husserl .Versión digital. http://www.google.com.co/\#hl=es\&sclient=psyab\&q=esbozo+de+una+semblanza+de+e.+ husserl+\&oq=esbozo+de+una+semblanza+de+e.+husserl+\&gs_l=hp.3..173876.174280.2. $\underline{174848.3 .3 \cdot 0 \cdot 0 \cdot 0 \cdot 2 \cdot 267.508 .2-}$

2.2.0...0.0...1c.1.5.psyab.pcEqIoiTxLw\&pbx=1\&bav=on.2,or.r_gc.r_pw.r_qf.\&bvm=bv.43 $\underline{287494, \text { d.eWU\&fp }=882 \text { ea22d9c37df7d \&biw }=1366 \& b i h=667}$

HUSSERL. Edmund (1949) Ideas relativas a una fenomenología pura y una filosofía fenomenológica. México: F.C E

(1962) Phanomenolgische Psychologie. Vorlessungen sommersemester 1925. Den Haag: Martinus Nijhoff. (Psicología Fenomenológica. Lecciones del semestre de verano de 1985)

(1977) La relación del fenomenólogo con la historia de la filosofía. EN: Actualidad de Husserl UNAM. México: ALIANZA.

(1980) Experiencia y Juicio. México: UNAM

(1982) La idea de la fenomenología. México: F C E

(2006) Investigaciones lógicas I. Madrid: Alianza Editorial.

(1985) Fenomenología y Antropología. En: Anuario de filosofía jurídica y social: ed. Sociedad chilena de filosofía jurídica y social. Pág. 365-377

(1992) La filosofía como autorreflexión de la humanidad. EN:

Invitación a la filosofía. pág. 129-142

(1995) Carta a Levy-Bruhl. EN: ER, Revista de filosofía No. 19.

Pág. 170-175

(1997) Thing and space. Lectures of 1907. Kluer academic publishers London. Versión en línea. http://es.scribd.com/doc/60798453/Husserl-Thingand-Space-Excerpt

(1998) Filosofía Primera. Bogotá: Grupo Editorial Norma. 
(2008) El mundo de la vida. Expliciatacines del mundo predado y

de su constitución. Textos del legado (1916-1937) Husserliana XXXIX.

(2009) Conferencias de parís. México: UNAM

(2012) Conferencias de Londres. Ediciones sígueme:

SALAMANCA.

(1954) Origen de la geometría. Pág. 365-386 En: Estudios de

Filosofía 4.

HUSSERL, Malvine (2013) Esbozo de una semblanza de Edmund Husserl. Versión en línea. http://es.scribd.com/doc/133846092/MalvineHusserl-Semblanza-Husserl

IRIBARNE, Julia. (2002) Edmund Husserl. La fenomenología como monadología. Academia Nacional de Ciencias de Buenos Aires: Buenos Aires.

LLANOS, Hector. (2014) Las rutas de la herencia prehispánica. Cap. 2. Caminos del

Guacacallo. Versión en línea:

http://www.banrepcultural.org/blaavirtual/historia/caminos/rutas2.htm

MERLAU-PONTY, Maurice. (1995) El ojo y el espíritu En: Revista ECO, p. 365-410

(1970) Lo visible y lo invisible. Seix Barral: Barcelona.

PEREZ DE BARRADAS, José (1943) Arqueología agustiniana. Biblioteca de cultura Colombiana: Ministerio de Educación Nacional.

PREUSS, K Theodor (1974) Arte monumental prehistórico. Dirección de divulgación cultural de la Universidad Nacional de Colombia: Bogotá.

READ, Herbert. (1994) El arte de la Escultura.

REICHEL-DOLMATOFF, Gerardo (1975) Contribuciones al conocimiento de la estratigrafía cerámica de San Agustín. Colombia, biblioteca del banco popular: Bogotá.

(1972) San Agustin a culture of Colombia. Praeger Publishers:

New York. Washington. 
RENGIFO, L. (1964). La proporción Armónica en la estatuaria Agustiniana. Universidad Nacional. Imprenta nacional

SOBREVILLA, David (1994) Situación y tareas actuales de la filosofía en América. EN:

SÁNCHEZ. Efraín, (2011) El mundo del arte en San Agustín. Villegas editores: Bogotá.

SOTOMAYOR. M.; Uribe, M. (1987) Estatuaria del Macizo Colombiano. Instituto Colombiano de Antropología, Imprenta Nacional de Colombia. Bogotá

VARGAS, GUILLEN, Germán. (2010) Mundo de la vida y fenomenología del lugar. En Anuario Colombiano de Fenomenología. Vol. IV, pág. 52-67

VELANDIA. Cesar Augusto, (2011) iconografía funeraria en la cultura arqueológica de San Agustin Colombia. Universidad del Tolima: Ibagué.

WALDENFELS, Bernhard. (2008)Visión plástica. Merleau-Ponty tras las huellas de la pintura.

\section{Sitios en línea:}

http://www.sanagustinstatues.org/bienvenidaen.html

http://www.icanh.gov.co/parques_asociados/parques_arqueologicos_nacionales/parque_ar queologico_san_agustin

http://www.museonacional.gov.co/sitio/el_silencio_de_los_idolos/galeria.html

http://www.britishmuseum.org/about_us/news_and_press/press_releases/2013/beyond_el_ dorado.aspx 